Historic, Archive Document

Do not assume content reflects current scientific knowledge, policies, or practices. 



\section{Notice to Correspondents}

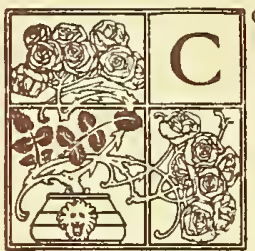

ORRESPONDENTS will greatly oblige by observing as far as possible the following directions:

All orders as well as all names and addresses should be written out legibly and in full; and it will greatly facilitate shipments if orders are sent in early.

It is requested that explicit directions for marking and shipping packages accompany each order. When it is left to us to choose the mode of conveyance we will exercise our best judgment. We pack in such a manner that ornamental trees, shrubs, evergreens and hardy border plants can go safely by freight. In all cases the articles are at the risk of the purchaser after being shipped; if delay or loss occurs the forwarder alone must be held responsible. While we agree to supply thrifty trees, shrubs and plants, we do not warrant them after shipment, nor are we responsible for losses resulting from natural causes.

Our customers are requested to notify us instantly of any errors that may be committed in filling their orders, that we may at once make ample amends, as we desirc to conduct our business in all respects satisfactorily to those who favor us with their confidence.

TERMS.-Cash with order or a satisfactory reference from strangers. Dealers and those having an established rating need not send reference.

Fiemittances should be made by Post Office Money Order, Drafts on Boston, or New York Banks, or Express Money Orders. Postage stamps will be found a convenient method of remitting for small amounts and can be used by us to advantage.

Prices in this catalogue cancel all previous quotations. A discount of 5 per cent is allowed when cash accompanies order.

THE PLANTING SEASON.-The planting season is not regulated by any particular month or day. We begin shipping as soon as the frost leaves the ground in the spring, and continue until June. Evergreens can be planted in August. Deciduous trees and plants are generally in condition to be moved by September 15 th, and fall planting can be continued until the ground becomes frozen.

FUMIGATION AND INSPECTION,-Our nurseries are inspected twice cach year by the State Entomologist, and are kept absolutely free from all insects and pests.

CONDIIIONS OF SALE.--While it must be obvious that it is to our best interest to send out stock which will not only grow, but prove true to name and description, and although we use all care and precaution possible, we give no warranty, express or implied, of any trees, shrubs, plants bulbs or seeds we sell, and we will not in any way be responsible as to the description, quality productiveness, crop or otherwise. If the purchaser docs not accept the goods under these conditions, they must be at once returned.

NOTE.-Trees and plants when shipped from the nursery are in condition to satisfactorily take hold and thrive when properly treated, and when failures occur, they are generally due to improper handling and planting, or causes beyond our control, i. e., weather conditions or unfavorable soil and we respectfully ask that the brief planting directions given on following pages be carefully noted.

\section{O N T E N T S}

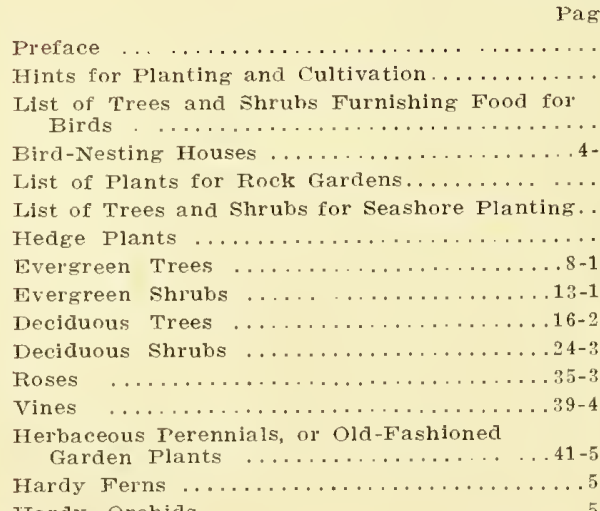

Hardy Orchids Flowering Bubs...............55-57 Annuals of Bedding Plants ................ 88 Old-Fashioned Herbs for Kitchen Gardens.....58 Fan-trained Fruit Trees for Covering Walls and Trellises ...................... 99 Number of Trees and Plants to an Acre ......59 Standard and Dwarf Fruit Trees ........59-65 Small Fruits ..................66-67 Strawberry Plants for Spring Planting........68 Pot-Grown Strawberry Plants for Fall Planting. 68 Garden and Flower Seeds................69 Insecticides $\ldots \ldots \ldots \ldots \ldots \ldots \ldots \ldots \ldots \ldots \ldots$ Lawn Grass ...................... Fertilizer ......................... Approximate Freight and Express Rates to

Principal Shipping Points.. Third Cover Page General Index ............. $11-72$ 


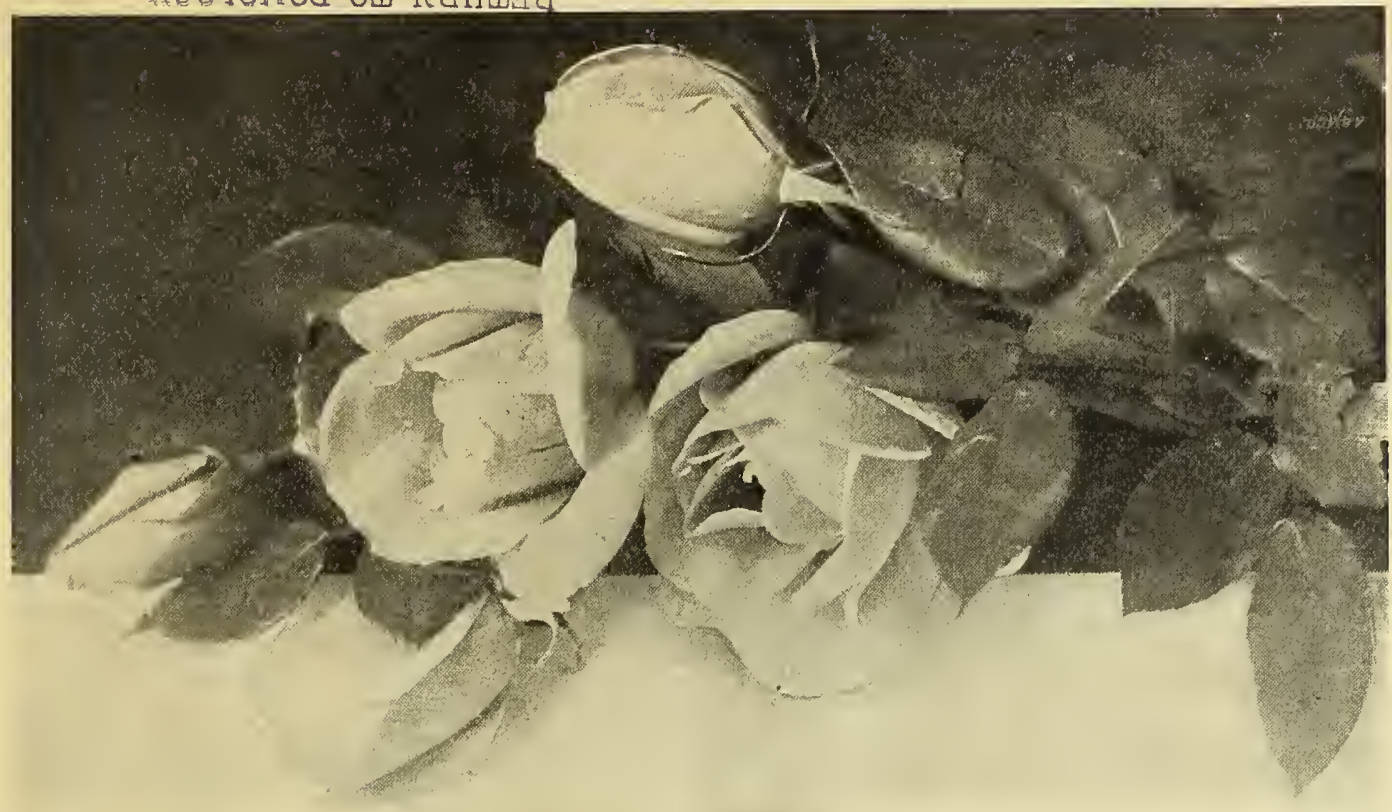

\section{P R E F A C E}

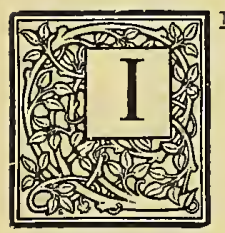

N PRESENTING this catalogue, which we have endeavored to make both very complete and of assistance in solving planting problems, we wish to express again our sincere thanks to all those who have favored us so generously. At the beginning of our career, we determined to conduct our business on the principles prescribed in the Golden Rule, and we are happy to say to our many loyal friends and customers that this policy has proved a success. That our customers are our friends is made evident to us in many valued letters received, expressing approval of the quality of stock sent, careful packing and general satisfactory manner of handling the business which has been entrusted to us. In all manners have we been favored, and with a sense of sincere appreciation we cnter upon a new year of business, equipped better than ever for handling our steadily growing trade.

Our Stock of Trees and Plants, which are grown under severe climatic conditions, we confidently recommend as the hardiest and best obtainable. Winters start here about December 15 , and generally end by March 15 . The lowest record of recent years was reached in January, 1914 , when the thermometer registered 32 degrees below zero. Our usual record is $22-25$ below, and it is safe to say that "Bedford grown trees and plants will live and thrive everywhere."

While we give our best efforts to produce and furnish high grade trees and plants, and do not attempt to pose as landscape architects; we are always happy to give such assistance as we can to customers in making the proper selection of what to plant, and advice as to the care of plants, and we respectfully invite correspondence pertaining to problems of interest to planters.

\section{Prices}

The prices given in this catalogue, we believe, represent a fair value for such high grade stock as we always endeavor to supply.

\section{Location of Our Nurseries}

Located 15 miles from Boston, 12 miles from Lowell, 3 miles from Concord, and 5 miles from Lexington, our nurseries can be reached via Boston \& Maine trains from the North Station, Boston, or via electric cars from Arlington Heights. The cars connecting Arlington Heights and Concord pass directly through our property.

Visitors are always cordially welcome, but we ask the indulgence of parties calling during our busy Spring and Fall months, when it is quite impossible for us to devote as much time as we should wish in showing our nurseries. The most courteous treatment possible, however, will always be given to those who favor us by calling.

Tel. Lexington $274 \mathrm{~W}$

The New England Nurseries Bedford, Massachusetts 


\section{Directions for Planting and Care of Trees and Plants When First Received from the Nursery}

As the life and well-being of a tree depend very much upon the care and treatment it receives after it leaves the hands of the nurseryman, and as a large proportion of the trees that are lost fail for want of proper treatment, we desire to offer a few hints upon the subject of transplanting, etc. The first important requisite to the successful raising of an orchard is the proper preparation of the soil. This should be made dry and rich. Underdrained, if necessary, as trees will not thrive in soil constantly saturated with stagnant moisture. It should be well plowed and, if possible, the sub-soil plow should be employed.

Immediately on receipt, the trees and plants should be unpacked, the roots made wet and covered with earth. The roots should not be exposed unnecessarily to the sun or wind.

THE SOIL. Any good garden soil is suitable. Avoid excess of sand or gravel. Provide a liberal depth of loam mixed with manure, but the roots should not be allowed to come in contact with the fertilizer used.

PLANTING. Dig holes large enough to accommodate roots without erowding, and set tree or plant a little deeper than they were standing in the nursery. (This is usually shown by soil marks on trunk or stem of plant.) Roses, Privets and Grapes particularly must be planted 4 to 5 inches deeper. Good loam should be worked in among the roots and carefully compacted. In the case of Rhododendrons, Evergreen Trees or other plants received with a compact ball of earth and roots, the roots should not be unnecessarily disturbed or balls broken.

WATERING. After planting it is well to apply a sufficient amount of water to penetrate the soil to a depth of 1 to 2 feet, and it is well to remember that one heavy application of water is more beneficial than frequent light applications. Frequent cultivation of the surface soil reduces loss of moisture by evaporation.

PRUNING. Roses should at once after planting be cut to within 4 to 5 inches of the ground. From deciduous trees and shrubs, one-third to one-half of the growth of the previous summer should be removed.

TMME FOR PLANTING. All hardy trees and plants of any description can be safely transplanted in the Spring as soon as frost leaves the ground, and usually as late as about June 1 st. Also during the period beginning September 15th and continuing until the ground becomes frozen. Evergreen trees and shrubs can further be safely handled during August.

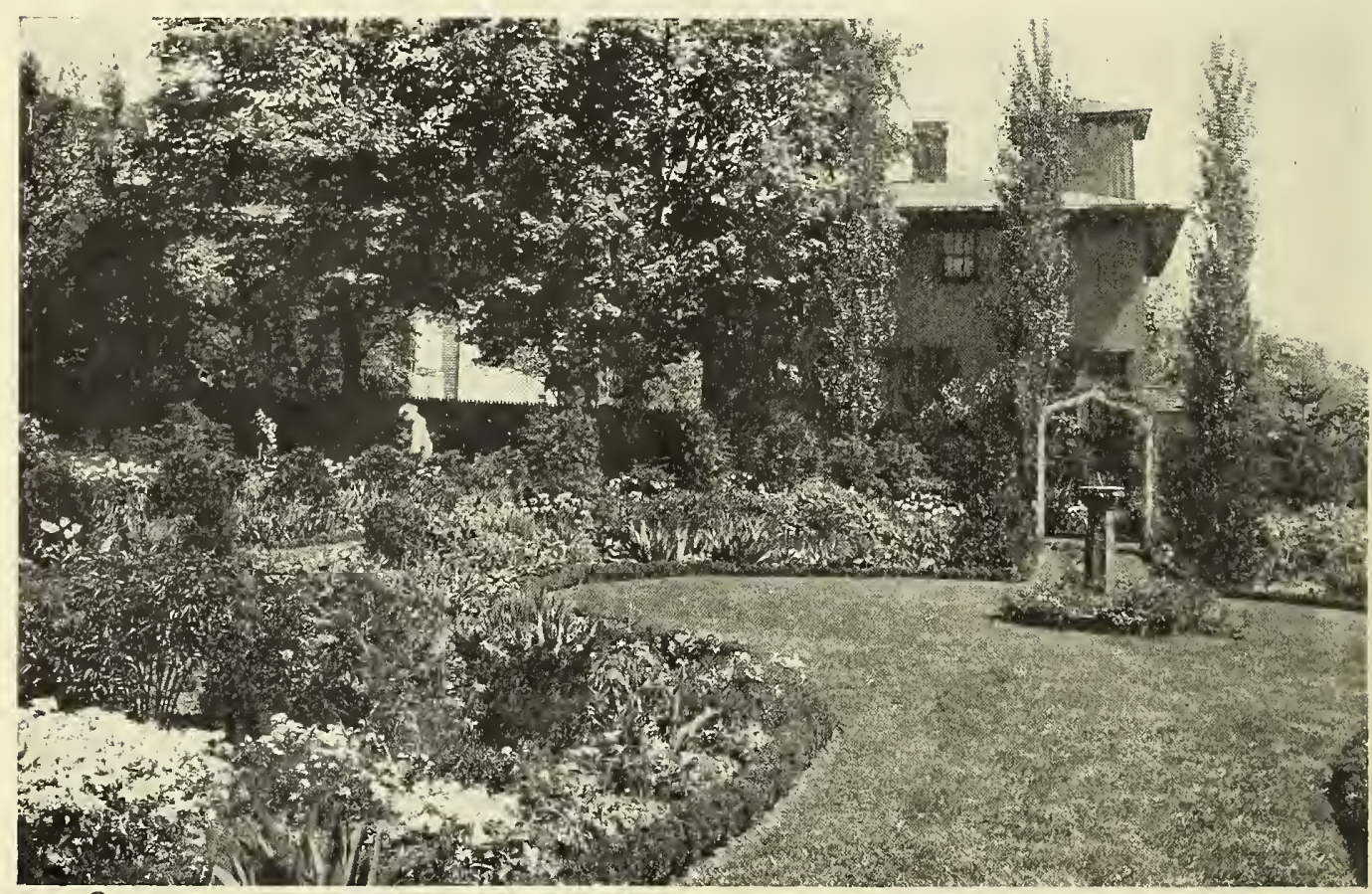

A Delightful Old-Fashioned Garden. 


\section{Planting to Attract Birds}

"The love of birds and trees is one of the healthiest emotions of the human heart. It may well be cultivated. There is no more innocent and no more gratifying source of enjoyment than intelligent interest in the beauties of Nature."

A garden is doubly attractive if filled with birds as well as flowers, and plants and shrubs thrive better where there are many birds to eat the weed-seeds and destroy the insects and worms.

The following is a list of fruit-bearing trees, shrubs alld vines furnishing food for birds, and the birds which feed up. on the various kinds.

Selection of varieties should be made with some regard to the character of the location to be planted, and the lists below have been arranged on that basis.

For description of plants named, see General Index.

(Numbers given correspond with appended list of birds).

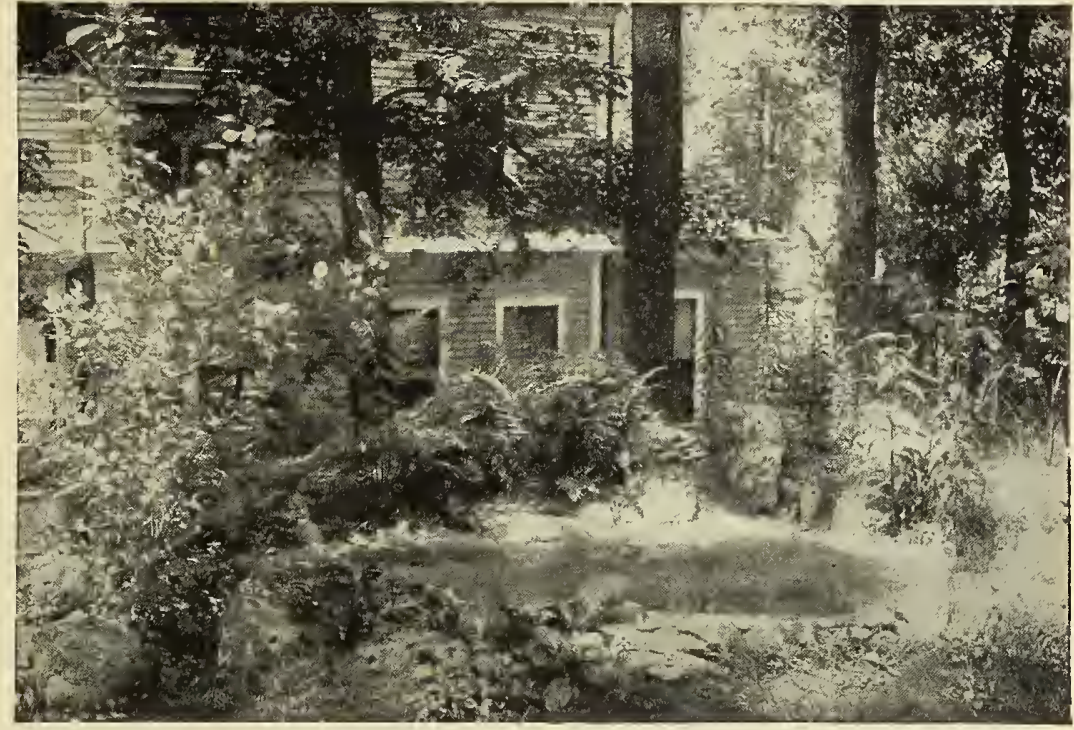

Bird-Pool at Residence of George H. Mellen, Esq., Newton, Massachusetts.
Hillside, among Rocks and Thin Soil

Ampelopsis (W o o dbine) $2,7,11,14,17$, $18,19,26$.

A. quinquefolia.

A. Engelmanni.

A. Veitchii

Celastrus (Bittersweet)

$2,11,17,18,26$

C. paniculata

C. scandens.

Juniperus (Juniper or Cedar) $2,5,7,9,10$ $14,16,17,18,19,23$. 25,26 .

J. communis.

J. Virginiana.

yycium. (Box-thorn or Matrimony Vine) 1,2 $5,10,11,17,19$.

L. barbatum.

Myrica cercifera. (Bayberry) $1,6,7,11,14$,

$17,18,19,20,25,26$.

Rhus. (Sumach) 1,2 ,

$$
4,5,6,7,10,11 \text {, } 12 \text {, }
$$

\section{For Planting in Shade}

Berberis. (Barberry). 5 , $7,11,14,17,18,19,26$.

B. Thunbergii.

B. vulgaris.

B. vulgaris purpurea.

Cerasus. (Cherry). 1 ,

$4,5,7,10,12,14,15$ $18,22,25,26$.

C. avium.

C. Pennsylvanicum.

C. Serotina.

Euonymus. (Strawberry or Spindle Tree) $2,18,19,26$

E. (All varieties)

Morus. (Mulberry). 1 $2,3,4,5,7,8,10$, $11,12,14,16,17,18$ $19,21,22,24,26$.

M. Tatarica.

M. var.New American. Pyrus. (Mountain Ash).

$2,5,9,10,11,18,19$ 26.

P. Sorbus Americana.

P. sorbus aucuparia.

\section{$\begin{array}{ll}14,17, & 18 . \\ 24,25,26 .\end{array}$}

R. glabra.

R. typhina.

Rosa. (Rose). Hips of the following varieties are eaten by many species

$R$ blanda.

R. Carolina.

$R$. Iucida.

R. multiflora Japonica.

$\mathrm{R}$, nitida.

R. Rubiginosa.

R. rubrifolia

R. rugosa.

R. rugosa alba

$R$. setigera.

R. spinosissma

ichuraiana.

accinium Pennsylvanicum. (Huckleberry) $4,5,7,11,12,14,18$ 19,26 .

\section{P. Sorbus pendula.}

$P$. Sorbus quercifolia.

Rhus. (Sumach). 1, 2, $14,17,18,19,20,22$, $24,25,26$.

R. glabra.

R. typhina.

Rosa. (Rose). All varieties as named under "Hillside, among rocks, etc."

rocks, etc." 5,71 $17,18,19,22,25,26$ V. acerifolium.

V. cassinoides.

V. dentatum

V. lantana.

V. Lentago.

$V$. opulus.

vites. (Grape). 1, 5, 7, $11,12,14,17,18,19$, 22,26 .

V. heterophylla.

V. Labrusca.

v. riparia.
Moist Soil and Marsh Land

Amelanchier botryapium. (Shad Bush). 1, $2,5,7,10,12,15,18$ $21,26$.

B e nzo.in odoriferum (Spice Bush). 11, 17, $19,26$.

Cephalanthus occidentalis. (Button Bush)

$5,10,11,17,18$ Cornus. (Cornel or Dog-
wood). $1,2,4,5,6,7$, wood). $1,2,4,5,6,7$
$10,11,12,14,17,18$ $19,20,22,24,26$.

C. alba.

C. alternifolia

C. Florida.

C. paniculata.

C. sanguinea

C. sericea

C. stolonifera.

Crataegus. (Hawthorn).

$7,11,12,18$

C. Coccinea.

C. cordata.

C. Crus-galli.

C. oxycantha.

\section{The Birds}

Following are the names of the birds which feed upon the fruits of the trees and shrubs, etc., enumerated-above. The numbers correspond with those in the list of plants.

$\begin{aligned} \text { 1. } & \text { Blackbird. } \\ \text { 2. } & \text { Bluebird. } \\ \text { 3. } & \text { Bobolink. } \\ \text { 5. } & \text { Catbird. } \\ \text { 5. } & \text { Cedarbird. } \\ \text { 6. } & \text { Chickadee. } \\ \text { 7. } & \text { Crow. } \\ \text { 8. } & \text { Cuckoo. } \\ \text { 9. } & \text { Finch. } \\ \text { 10. } & \text { Grosbeak. } \\ \text { 11. } & \text { Grouse. } \\ \text { 12. } & \text { Jayi. } \\ \text { 13. } & \text { Junco. }\end{aligned}$

14. Kingbird.

15. Oriole.

17.

18. Robin.

19. Sparrow.

20. Swallow.

21. Tanager.

22. Thrasher

23. Thrush.

24. Vireo.

26. Woodpecker.

We invite correspondence relative to any planting problem, and are always happy to assist our customers in making the best selections of material for any named purpose. 


\section{Bird Nesting-Houses}

Believing that the growth and success of the nursery stock we send out is materially increased by the presence of birds, we have decided to undertake the sale of four types of nesting-boxes and to urge our customers to put them up in as large numbers as they have opportunity.

Bird-houses, if attractive, add to the beauty of the garden in themselves, and the birds "pay the rent" many times each season by their constant search for food.

Few people realize how simply and at what slight cost wild birds may be attracted, or how many varieties of our native wild birds will build in nesting boxes. House wrens, nuthatches, chickadees, tree swallows, martins, bluebirds, downy woodpeckers, starlings, titmice crested flycatchers, flickers, screech owls, pileated woodpeckers wood ducks and barn owls are among the birds that have been known to nest in one or several of the types of boxes mentioned below.

We are entirely impartial in our sale of these boxes, having selected the four styles that seem to have given best results, each having some especial advantage to recommend it. We do, however, strongly urge our customers to put up as many as they have room for, selecting the style best suited to the birds they wish to attract.

\section{Packard Bird-Houses}

Designed by Mr. Winthrop Packard, the Secretary-Treasurer of the Massachusetts Audubon Society. These houses are round, soft gray in color, unobtrusive, made of fibre, very light yet will stand drenching rains and heavy gales, are well ventilated, easily cleaned and put up-and the birds love them. Moreover, they are inexpensive, 35 cents each or three for $\$ 1.00$. Made in two sizes, the smaller for chickadees and little birds, and the larger for bluebirds, downy woodpeckers and tree swallows.

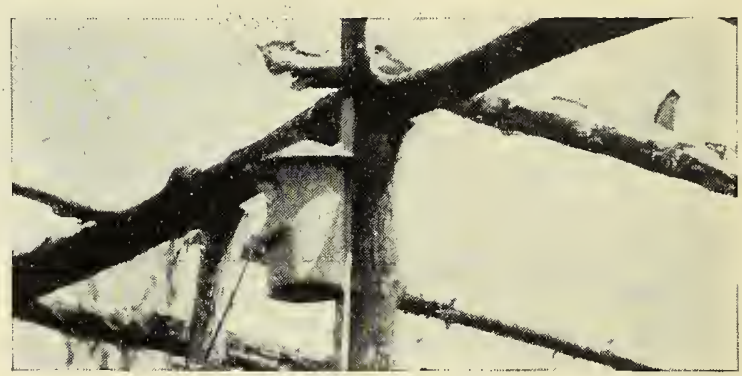

Packard Bird Houses.

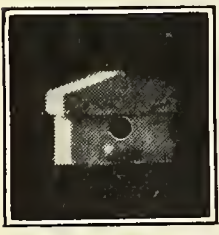

Gray Cement Wren Box.

\section{Gray Cement Wren Box}

This box was first designed to protect the birds in the maker's garden from the English Sparrows, and proved so successful that it has been difficult to supply the demand. Wrens raise two broods each year, but only one in the same nest, so if they are wanted for the whole season, two boxes must be given each family. During 1914, twelve nests were built in these boxes in a garden space of one acre. Careful watch was kept, and it was found that bugs, worms and moths were carried to the hungry babies at about the rate of one each minute. Ventilated, removable lid, hangs on a nail. $\$ 1.50$ each; $\$ 7.50$ half dozen.

\section{Pinedale Bird Nesting-House}

Made of wood, colored reddish-brown, with removable top. The feature of this box is the circle of tin, colored to match the box, around the entrance, which prevents gnawing by squirrels, sometimes a serious difficulty. These boxes are made in three sizes, price 35 cents each for the smaller ones, and 75 cents for the flicker size. This is the most inexpensive flicker box that we have been able to find.

\section{Berlepsch Nesting-Boxes}

These boxes, first invented and used by Baron Berlepsch of Germany, are undoubtedly the best made for the larger birds. Mr. Ernest Harold Baynes, General Manager of the Meriden Bird Club, personally supervises their manufacture in America, and uses them with wonderful success. They are made of branches, taken from actual forest trees, hollowed out by special machinery, giving a grooved interior upon which the birds can get a foot-hold, and have a hinged top which makes

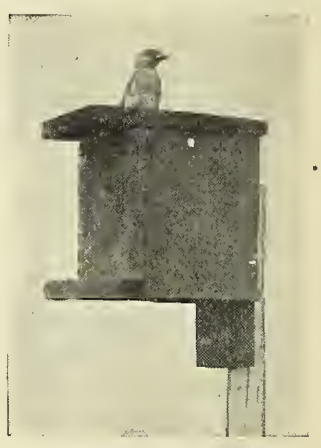

Pinedale Bird-nesting House. it easy to clean them out. Very attractive when in position, adapted in size to every American wild bird nesting in tree-holes, they are the ne plus ultra of artificial bird homes.

\section{PRICFS OF BERLEPSCH NESTING BOXES}

Size No. 1, for House Wrens . ................. \$1.00 each; $\$ 90.00$ per hundred Size No. 2, for Nuthatches, Chickadees, etc............ $\$ 1.10$ each; $\$ 95.00$ per hundred Size No. 3, for Downy Woodpeckers, etc.............\$1.25 each; $\$ 110.00$ per hundred Size No. 4, for Flickers, Screech Owls, etc...........\$1.35 each; $\$ 120.00$ per hundred Size No. 5, for Pileated Woodpeckers, etc ...........\$\$1.50 each; $\$ 130.00$ per hundred Size No. 6, for Wood Ducks, Barn Owls, etc..................... $\$ 2.00$ each 


\section{English Sparrows}

These birds have proved themselves one of the greatest foes of our native wild birds. One of the best methods of fighting them is by use of traps, and the Dobson Sparrow Trap is used with much success by many people. The price is $\$ 5.00 \mathrm{~F}$. O. B. Chicago. Sample may be seen at our grounds. See cut below.

\section{General Directions}

For Locating and Erceting Bird NestingHouses.

All bird houses with an entrance hole high above the bottom and a projecting roof to shut out sun and rain, may face either to the south or west, if put up in the shade; if put up in the sun, it is better to have them face the west. The objection to the north or east exposure is on account of occasional severe cold northerly or easterly storms, but in sheltered situations, entrance hole may face the north or east.

Nesting-boxes for Chickadees may be put up in open woods, on the edge of the woods, in orchards, or on shade trees, but Chickadees will not nest where there are many English Sparrows.

Nesting-boxes for Bluebirds and Wrens may be put on trees, poles, or buildings, and need not be over eight or ten feet from the ground.

Those for Swallows should be on poles ten or twelve feet from the ground, or on roofs of buildings; never on trees.

Martin houses should always be on poles at some little distance from trees or buildings, and not less than twelve feet from the ground; flfteen or twenty feet is better.

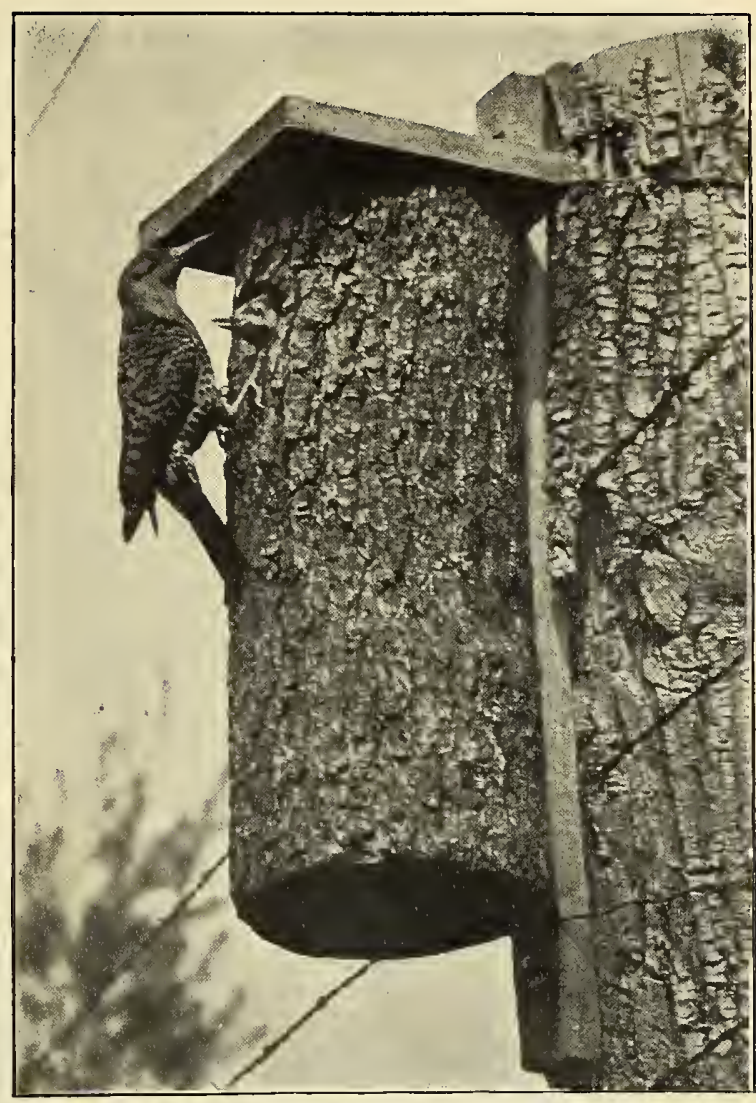

Berlepsch Nesting Boxes. (See page 4.)

Very few birds will nest in boxes placed in the woods unless the woods are very open. Most boxes placed in trees should be either in orchards or in shade trees, in open fields or on the edges of woods. When first putting up nesting-boxes, better success is assured if they are placed about two hundred feet apart. After the first season more boxes can be added to advantage.

Sometimes a Chickadee can be induced to nest in a box by putting about two inches of cotton batting on the bottom. As an experiment, put a little. hay in one of the Bluebird or Swallow boxes to see if this attracts them, as it sometimes does.

A Flicker box must be placed on the trunk of a large tree, ten to twenty feet from the ground. It must have on the bottom at least three or four inches of ground cork or dry earth and sawdust mixed, otherwise Flickers will not use it, for they make no nest, only a hollow to keep their eggs from rolling. EDWARD HOWE FORBUSH,

Sparrow Trap. State Ornithologist of Massachusetts.

\section{Announcement}

All these nesting-boxes are in position on the nursery grounds at Bedford, where there has also been built a bird-pool, surrounded by suitable plants.

In response to many inquiries, we have published a pamphlet on "Practical Methods of Attracting Wild Birds," by Mrs. George H. Mellen, of Newton. Price in paper" cover. 25 cents; board cover, 35 cents. Prof. C. J. Maynard, the well-known ornithologist, says of Mrs. Mellen's success: "I have been very much interested in your account of your birds. I think it very remarkable that you are able to attract so many birds in such a settled section of the city." 


\section{Plants Particularly Adapted for Rock Gardens}

For descriptions, see General Index.

Adiantum pedatum (Maidenhair Fern). See hardy Ferns.

Adonis vernalis (Spring Adonis).

Agopodiun podograria variegata.

Ajuga reptans (Bugle).

Alyssum saxatile compacta (Madwort).

Anemone Pennsylvanicum.

A. pulsatilla.

A. sylvestris.

Aquilegia Canadensis (Columbine).

1. corivien.

Arabis albida (Rock-cress).

A. alpina.

Arctostaphyllos Uva Ursi (Bearberry).

Arenaria Balearica.

Armeria (Seapink). All varieties.

Artemisia frigida (Southernwood)

A. Pontica.

A. Stelleriana.

Asperila odorata (Sweet Woodruff.)

Aster Alpinus (Alpine Aster).

Aubretia deltoides (Rock-cress).

Callirhoc involucrata (Poppy Mallow).

Campanula carpatica (Harebell).

C. rotundifolia (Scotch Bluebell)

Cerastium tomentosum (Mouse-ear).

Cypripedium acaule (See Hardy Orchids).

C. spectabile (See Hardy Orchids).

Daphnc cneorum.

Dennstaedtia (Dicksonia).

Punctilobula. (See Ferns).

Dianthus deltoides (Maiden Pink).

D. plumarius (Grass Pink).

Dodecatheon meadia (Shooting Star).

Epimedium alpinum (Bishop's Hat).

Gentiana Andrewsii (Blind Gentian).

Geranium atrosanguinea.

G. maculatuni.

Goodyera pubescens (See Hardy Orchids)

Gypsophila repells (Creeping Baby's Breatn).

Hclianthcmum (Sunrose). All varieties.

Hclleborus niger (Christmas Rose).

Hepatica. (All varieties).

Heuchera sanguinea (Coral Bells).

Hieracium aurantiacum (Hawkweed).

Hypericum Moserianum.

Iberis (Candytuft). All varieties.

Iris cristata (Dwarf Iris).

I. pumila (Dwarf Iris).

Jasione perennis.

Juniperus Sabina (Savin).

J. Sabina, var. tamariscifolia.

Lathyrus latifolius (Hardy Sweet Pea).

Lilium tenuifolium.

Linum perenne (Flax).

Lychnis Chalcedonica (London Pride)

L. Flos-cuculi, var. plenissima.

L. Haageana.

I. viscaria, var. splendens (Ragged Robin).

Lycium barbatun (Matrimony Vine, or Boxthorn).

Lysimachia nummularia (Money-wort).

Malva moschata (Marsh Mallow).

Mertensia Virginica (Lungwort).

Myosotis palustris (Forget-me-not)

Euothera Missouriensis.

QE. fruticosa, var. Youngii.

Onoclea sensibilis (See Ferns).

Opuntia Missouriensis (Prickly Pear).

Pachysandra terminalis.

Papaver nudicaule (Iceland Poppy).

Phlox amoena (Dwarf Phlox).

P. divaricata (Dwarf Phlox).

P. ovata (Dwarf Phlox).

P. stellaria (Dwarf Phlox).

P. subulata (Dwarf Phlox).
Plumbago larpenta (Leadwort).

Polemonium reptans (Greek Valerian).

Primula officinalis (English Cowslip).

P. veris superba.

Rosa Wichuraiana (Trailing or Memorial

Rose).

Sanguinaria Canadensis (Bloocirnot)

Saxifraga cordifolia.

Scdum acre, (Golden Moss).

S. album (White Stonecrop).

S. Sieboldi.

S. stoloniferum.

Sempervivum (Houseleek). All varieties.

Silene Virginica (Fire-Pink)

Statice latifolia (Sea Lavender).

Thymus lanuginosus (Creeping Thyme).

Trillium (Wood-Lily). All varieties.

Tunica saxifraga.

Veronica incana (Speedwell).

V. repens (Creeping Speedwell).

V. rupestris (Creeping Speedwell)

Vinca minor (Myrtle).

Viola cornuta (Hardy Violet).

Woodsia Ilvensis (See Ferns).

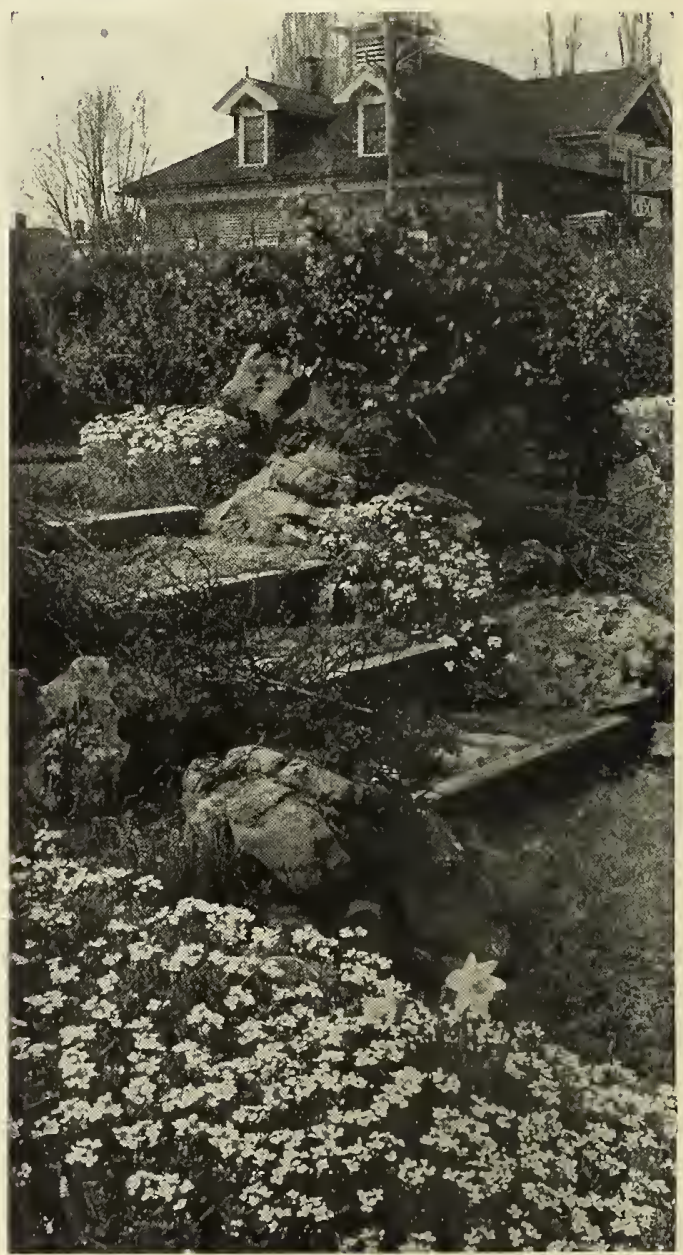

An Attraetive Rock Garden Planting of Arabis. 


\section{Trees and Shrubs for Seashore Planting}

Picea alba (White Spruce).

Juniperus communis prostrata (Common Juniper).

J. Sabina and its varieties (Savin).

Pinus Austriaca (Austrian Pine).

P. Mughus or montana (Mountain Pine).

P. Massoniana (Japanese Seashore Pine).

P. sylvestris (Scotch Pine).

Calluna vulgaris varieties.

Yucca Filamentosa (Adam's Needle).

Acer Ginnala (Bush Maple).

Amelanchier botryapium (Shad Bush).

Betula alba (White Birch).

Celtis occidentalis (Nettle Tree).

Cratagus coccinea (American white Thorn).

C. cordata (Washington Thorn).

C. Crus-galli (Cockspur Thorn).

C. Oxycantha (English Hawthorn).

Gleditschia triacantha (Honey Locust).

Platanus occidentalis (Plane or Sycamore).

Populus alba (White Poplar).

P. monolifera (Carolina Poplar or Cottonwood).

P. Bolleana (Bolle's Poplar).

Prunus maritima (Beach Plum).

P. pumilla (Sand Cherry).

Robinia Pseudacacia (Locust or Acacia).

Ptelia trifoliata or Hop-tree.

Willow (Laurel-leaved).

Willow (White).

Willow (Golden-barked).

Baccharis halimifolia (Groundsel Tree).

Bcrberis vulgaris (Common Barberry).

B. Thumbergii (Japan Barberry).

\section{Hedge Plants}

Clethra alnifolia (White Alder).

Colnus sericea (Silky Cornel).

Dirca palustris (Leather Wood).

Genista scoparia (Scotch Broom).

G. tinctoria (Broom).

Hippophrea rhamnoides (Sea Buckthorn).

Hypericum KaImianum (St. John's Wort).

Itea Virginica.

Ligustrum vulgare (Common Privet).

L. Ibota (Japanese Privet).

Lycium barbatum (Box Thorn).

I. Chineusis (Box Thorn).

Myrica cerifera (Bayberry).

Pyrus arbutifolia (Aronia).

Rhamnus crenata (Buckthorn-Holly-leaved).

R. Cathartica (Common Buckthorn).

Rhodotypos kerrioides (White Kerria).

Rhus copalliua (Dwarf Sumach).

R. glabra (Smooth Sumach)

R. typhina (Staghorn Sumach).

Robinia hispida (Rose Acacia).

Rubus odorata (Flowering Raspberry).

Symphoricarpus vulgaris (Indian Currant).

Viburnum dentatum (Arrow Wood).

V. Lentago (Sheepberry).

Rosa Rugosa (Ramona Rose).

R. Carolina (Swamp Rose).

R. lucida.

R. blanda (Meadow Rose).

R. nitida.

R. spinosissima (Scotch Pose).

R. multiflora (Jap. Rose).

R. setigera (Prairie Rose).

Following is a list of plants, deciduous and evergreen, which lend themselves well to the forming of attractive hedges or screens, and a table giving the distance apart for the the plants of a given size to be set, in order to form a dense growth. For full description of varieties, see General Index.

Aralia pentaphylla (Five-leaved Aralia)..

\section{Height}

Berberis Thunbergii (Japan Barberry)

B. vulgaris (Common Barberry).

B. vulgaris purpurea (Purple-leaved Barberry)

Cratxgus coccinea (American Thorn)

C. Crus-galli (Cockspur Thorn).

C. Oxyacantha (English Hawthorn)

Cydonia Japonica (Japan Quince)

Ligustrum Ibota (Japanese Privet)

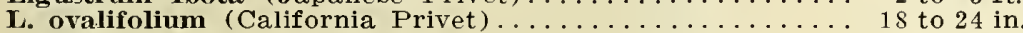

2 to $3 \mathrm{ft}$.

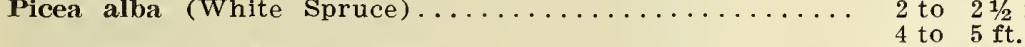

P. excelsa (Norway Spruce) ................. 2 to $2 \frac{1}{4} \mathrm{ft}$

4 to $5 \mathrm{ft}$.

6 to $7 \mathrm{ft}$.

Pinus strobus (White Pine) .................. 3 to $4 \mathrm{ft}$.

Rhamnus catharticus (Buckthorn)... 4 to $5 \mathrm{ft}$.

Rhamnus catharticus (Buckthorn) ...............

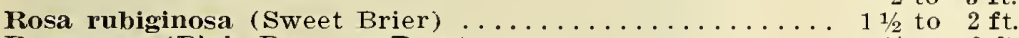

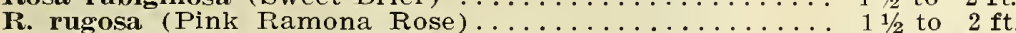

Salix pentandra (Laurel-leaved Willow) .............. 1 1/2 to $2 \mathrm{ft}$.

S. vitellina aurea (Golden-barked Willow) ........... 3 to 4 to $5 \mathrm{ft}$.

5 to $7 \mathrm{ft}$

7 to $9 \mathrm{ft}$.

Spiræa opulifolia (Ninebark) ................ $21 / 2$ to $3 \mathrm{ft}$.

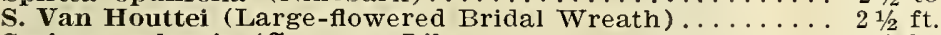

Syringa vulgaris (Common Lilac) ................ $2 \mathrm{ft}$

Thuya occidentalis (Arborvitae) .................

Thnya Canadensis (Hemlock) .............. $\begin{array}{r}2 \text { to } 2 \frac{1 / 2}{1} \mathrm{ft} \text { to } 1 \frac{1}{1 / 2} \mathrm{ft} .\end{array}$

2 to $2 \frac{1}{2} \mathrm{ft}$.

Viburnum dentatum (Arrow-wood).

\begin{tabular}{|c|c|c|}
\hline istal & ince & Price \\
\hline apar & & per 100 \\
\hline $11 / 2$ & ft. & $\$ 25.00$ \\
\hline & ft. & 10.00 \\
\hline 1 & ft. & 15.00 \\
\hline 1 & ft. & 15.00 \\
\hline 1 & ft. & 18.00 \\
\hline 1 & ft. & 18.00 \\
\hline 2 & ft. & 25.00 \\
\hline 2 & ft. & 30.00 \\
\hline $11 / 2$ & ft. & 20.00 \\
\hline 1 & ft. & 15.00 \\
\hline 1 & ft. & 15.00 \\
\hline 1 & ft. & 20.00 \\
\hline 1 & ft. & 15.00 \\
\hline 1 & ft. & 6.00 \\
\hline 1 & ft. & 8.00 \\
\hline 2 & ft. & 30.00 \\
\hline $21 / 2$ & ft. & 90.00 \\
\hline 2 & ft. & 30.00 \\
\hline $21 / 2$ & ft. & 90.00 \\
\hline 3 & ft. & 150.00 \\
\hline 21 & ft. & 45.00 \\
\hline $21 / 2$ & ft. & 60.00 \\
\hline 1 & ft. & 15.00 \\
\hline 1 & ft. & 20.00 \\
\hline 1 & ft. & 15.00 \\
\hline $1 \frac{1 / 2}{}$ & $\mathrm{ft}$. & 15.00 \\
\hline $11 / 2$ & ft. & 15.00 \\
\hline 2 & ft. & 20.00 \\
\hline 2 & ft. & 20.00 \\
\hline 3 & ft. & 30.0 .0 \\
\hline 3 & ft. & 40.00 \\
\hline 2 & ft. & 20.00 \\
\hline 2 & ft. & 20.00 \\
\hline ? & ft. & 20.00 \\
\hline 2 & ft. & 25.00 \\
\hline 2 & ft. & 30.00 \\
\hline $11 / 2$ & ft. & 30.00 \\
\hline $11 / 2$ & ft. & 50.00 \\
\hline & ft.. & 65.00 \\
\hline 2 & ft. & 25.00 \\
\hline
\end{tabular}




\section{Evergeen Trees}

We ship no Evergreens which have not been transplanted several times. An Evergreen which has not been transplanted is often a finer specimen than transplanted stock but it is of little value to the buyer. The larger sizes are shipped with compact balls of roots wrapped in burlap. This method insures the plants against loss.

Abbreviations denoting size at maturity: "L," large; "M," mediun ; "S," small; "D," dwarf; "VD," very dwarf. Rapidity of growth: "r," rapid; "m," medium; "s," slow.

We can supply extra large specimens of a great many varieties, and are always pleased to give special quotations on such.

Evergreen trees should be planted extensively, as they are equally attractive at all seasons. In winter they afford a shelter from the wind better than do deciduous trees, for which reason they are much appreciated by the birds, who also feed upon the seeds of many varieties.

"Trees, plants and flowers talk to us grandly, lovingly, beautifully. To learn their language we must give attentive ears, eyes and minds, then their speech will minister continually to our happiness." Tree Talk.

\section{Abies - Fir}

Leaves flat, scattered and silvery beneath. Cones erect on the upper side of the branches. maturity, leaving the axis on the tree.

Abies balsamea (Balsam Fir). "L." Of rapid, slender, pyramidal growth, with very dark foliage. Grows in cold, wet ground as well as in better soil.

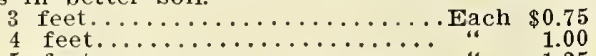

5 feet................ 1.25

Canadensis (Hemlock). See Tsuga Canadensis.

"Concolor (Blue Fir). "L.m." A native of Colorado. Grows to a height of 50 feet and more. the foliage varies in color from a glaucous blue to a very light green. It is graceful and feathery.

2 feet.................... Each $\$ 2.00$

3 to 4 feet.........

6 to 9 feet. Specimens.......... $\$ 6.00$ to 12.00

“Fraseri (The Southern Balsam). "L.r." A splendid native tree, like the Baisam Fir, but with darker, richer foliage.

2 to 3 feet................ Each $\$ 1.00$

" Veitchil (Veitch's Silver Fir). "L.m." Resembles the Nordmann's Fir, though the silvery tint is more pronounced. It is hardy and makes one of the grandest of specimens. The foliage is dark and massive.

2 to $21 / 2$ feet ............. Each $\$ 2.00$

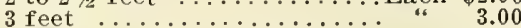

4 feet $\ldots \ldots \ldots \ldots \ldots \ldots \ldots \ldots \ldots \ldots$ " 4.00

" Hudsonia glauca (Hudson's Bay Dwarf Fir). "D.s." A dwarf. compact growing Fir, with dark blue foliage. Hardy and reliable. Rare.

2 feet ................. Each $\$ 2.50$

\section{Biota - Chinese Arborvitae} Biota orientalis. "M.m." Bushy and up-
right in growth. Foliage arranged in flat, vertical sprays.

2 feet 18 inches ............... Each $\$ 1.00$

"vær. aurea (Golden Biota). A form of the preceding, with bright yellow-tinged foliage

12 to18 inches

Each $\$ 1.25$

2 feet

\section{Cedrus - Cedar}

Cedrus Atlantica glauca. "M." Leaves very fine and of a delicate steel-blue tint equal to the finest of the glaucous Colorado Blue Spruces. Perfectly hardy in Northern Europe, and should succeed wherever the Retinosporas do well. Very rare.

3 feet

Each $\$ 2.00$

Chameactparis. (See Retinospora).

CUPRISSUS, var. Triumph of Boskoop. (Silvery Cypress). "M.m." Pyramidal in growth. Leaves flattened and steel-colored. Requires slight protection until well established. An extraordinarily handsome Evergreen. Very rare.

4 to 5 feet .............. Each $\$ 4.00$

\section{Juniperus - Juniper}

Juniperus Chinensis argentea, or foemina variegata. "D.s." Bluish-green foliage, very dense, interspersed with silvery-white. One of the best of Junipers in growth and appearance. A charming dwarf plant.

18 inches ................. Each $\$ 1.00$ 2 feet $\ldots \ldots \ldots \ldots \ldots \ldots \ldots \ldots \ldots \ldots \ldots$ " $\$ 2.00$

" communis. "V.D." Our common Juniper. Light glaucous foliage.

18 to 24 iuches .............. Each $\$ 0.75$

" var. aurea (Douglas' Golden). "V.D.s." Forms a mat-like, spreading growth of brilliant golden color. Valuable for edging and grouping.

15 to 18 inches .............. Each $\$ 2.00$

" var. Hibernica (Irish Juniper). "M.m." of dense, pillar-like growth. Glaucous green foliage.

2 to 3 feet ............... Each $\$ 0.75$

" var. Suecica compacta (Swedish Juniper). "M.m." Grows much as the Irish does, but of more bushy form.

2 to 3 feet ...............Each $\$ 1.00$

" Japonica aurea (Golden J'apan Juniper). "V.d." A splendid dwarf, golden form. Always bright, and a feature in any planting. 2 feet ................... Each $\$ 1.50$

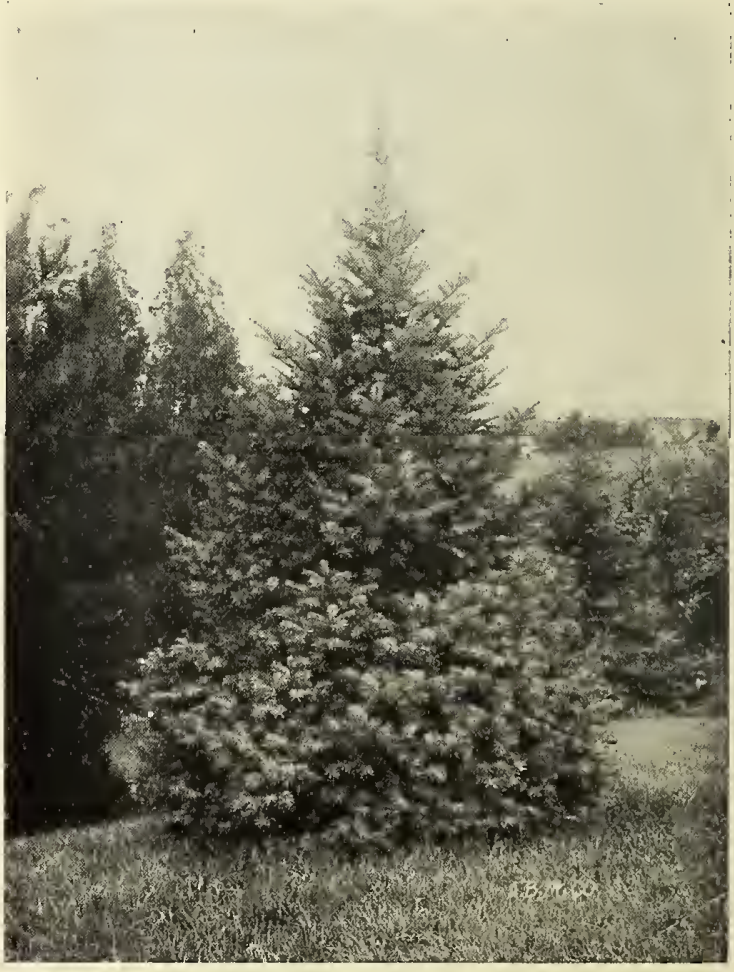

Abies Concolor-White Fir. 
Juniperus Pfitzeriana. "D" A beautiful new evergreen of graceful habit, resembling in form the well-known J. Japonica aurea, though in color the foliage is of a pleasing glaucous green.

$1 \frac{1 / 2}{2}$ to 2 feet ............... Each $\$ 1.50$

"Sabina (Savin Juniper). "V.D.s." Prostrate, spreading branches, with somber green foliage. Hardy and well adapted for hillsides, etc. 18 to 24 inches ............. Each $\$ 1.00$ 24 to 30 inches $\ldots \ldots \ldots \ldots \ldots \ldots \ldots$ * 1.50 3 feet. Specimens ............. " 3.00

" var. tamaricifolia (Creeping Savin). "V.d." Quite prostrate, creeping over considerable space; fine for rocks, walls and dry places.

12 to 18 inches .............. Each $\$ 1.50$

"Virginiana (Red Cedar). "M.m." Taperíng form, bright, rich green foliage. Useful for ornamental planting

2 feet $\ldots \ldots \ldots \ldots \ldots \ldots \ldots \ldots$ Each $\$ 0.50$

3 feet $\ldots \ldots \ldots \ldots \ldots \ldots \ldots \ldots \ldots \ldots \ldots \ldots \ldots \ldots \ldots \ldots$ " 1.00

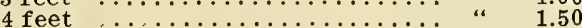

“ Virginiana glauca (Sílvery Red Cedar). "M.m." The foliage distinctly silver gray. Quite prominent among other Evergreens.

3 to 4 feet ................. Each $\$ 2.00$

4 to 5 feet $\ldots \ldots \ldots \ldots \ldots \ldots \ldots \ldots \ldots$ " 3.50

"var. Schotti. Fine, pyramidal habit. Foliage peculiarly bright green.

2 to 3 feet $\ldots \ldots \ldots \ldots \ldots \ldots$ Each $\$ 1.50$

\section{Picea - Spruce}

All the Spruces are very hardy, and desirable both as individual specimens on lawns or in masses. The White and Norway spruces are used extensively for windbreaks and hedges. Will give special quotations for these in quantities.

Picea alba (White Spruce). "L.m." Light, silvery green foliage and dense, pyramidal growth. Hardy in all locations, and particularly good for seashore planting.

3 to 4 feet ........................ $\$ 1.00$

4 to 5 feet $\ldots \ldots \ldots \ldots \ldots \ldots \ldots \ldots \ldots \ldots \ldots \ldots \ldots \ldots \ldots$

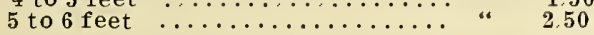

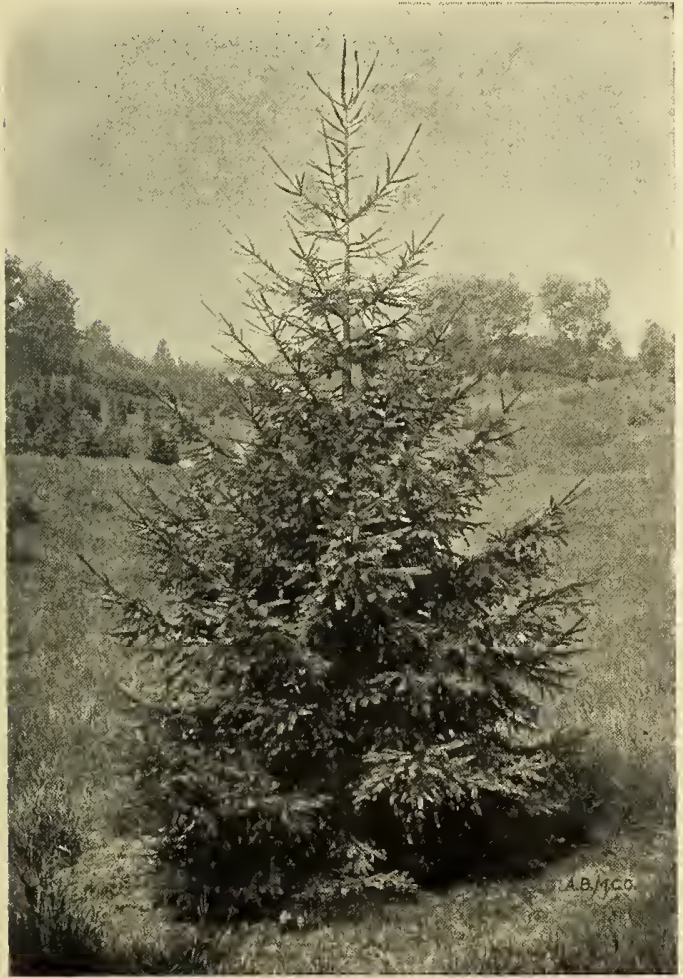

Picea excelsa-Norway Spruce.

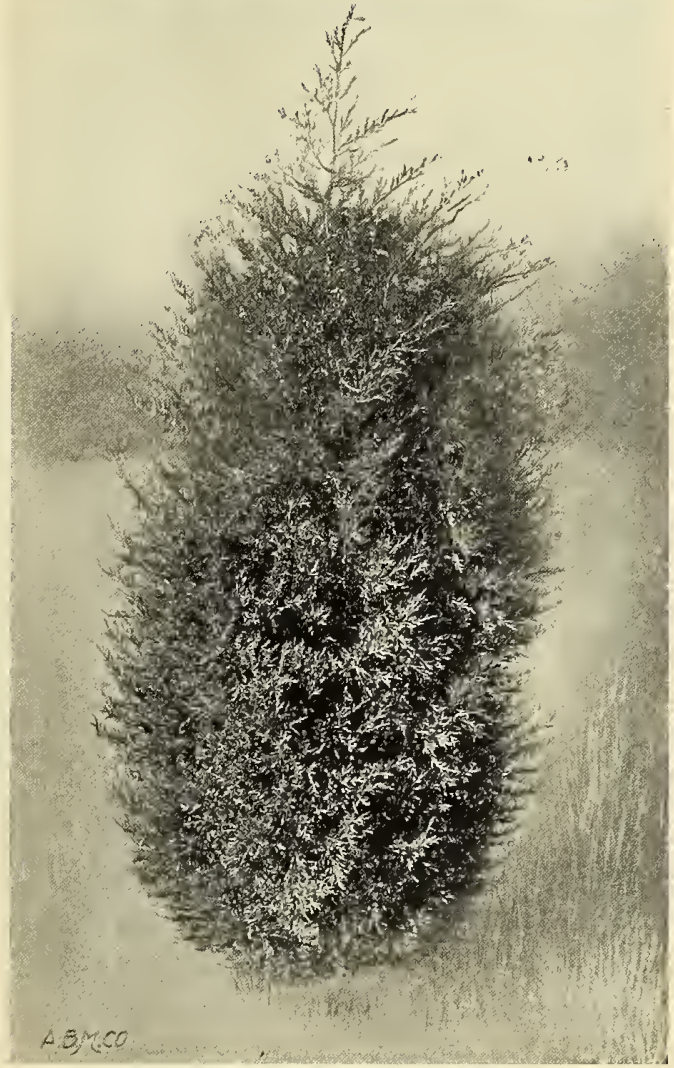

Juniperus Virginiana-Red Cedar.

"Alcockiana (Alcock's Spruce). "M.s." A Japanese tree of the greatest value. It is hardy and retains its foliage well, being always of good form. The silvery tint of the lower leaf surface is in brilliant contrast at all times with the deep green above.

2 feet $\ldots \ldots \ldots \ldots \ldots \ldots \ldots \ldots \ldots$ Each $\$ 1.00$

3 feet " 1.50

“ Engelmanni (Engelman's Spruce). "L.m." A choice and valuable Rocky Mountain tree of dense pyramidal growth. Has the stiff foliagc of $P$. pungens, and in most cases a fine glaucous color.

3 feet
4 feet $\ldots \ldots \ldots \ldots \ldots \ldots \ldots \ldots \ldots \ldots \ldots \ldots \ldots \ldots$

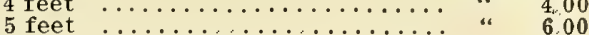

" excelsa (Norway Spruce), "L.r." The most generally used of Evergreen trees. Useful for screens and windbreaks on account if its rapid growth. It makes a tall tree, with room to develop; is of pyramidal, symmetrical growth, its lower branches sweeping the ground

3 feet ............................ $\$ 0.75$

4 feet $\ldots \ldots \ldots \ldots \ldots \ldots \ldots \ldots \ldots \ldots \ldots \ldots \ldots$ " 1.00

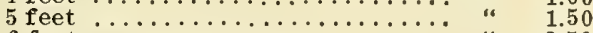

6 feet $\ldots \ldots \ldots \ldots \ldots \ldots \ldots$ " 2.50

7 to 8 feet. Specimens ....... “ 3.50

10 feet. Specimens .......... " 6.00

" var. aurea. "L.r." A golden-leaved form. In the early part of the season this is a brilliantly colored tree; quite a favorite with planters.

4 feet $\ldots \ldots \ldots \ldots \ldots \ldots \ldots \ldots$ Each $\$ 1.50$

5 to 6 feet ............ 2.50

" var. Gregoriana (Gregory's Spruce). "V.D.s." Forms a cushion-like growth of dense foliage. Very dwarf and ornamental. Rare.

15 to 18 -inch spread ..........Each $\$ 2.00$

" var. conica. "V.d.s." Cone-like growth; very dense, dwarf and compact. One of the best of small-growing conifers.

2 to 3 feet ............................ 


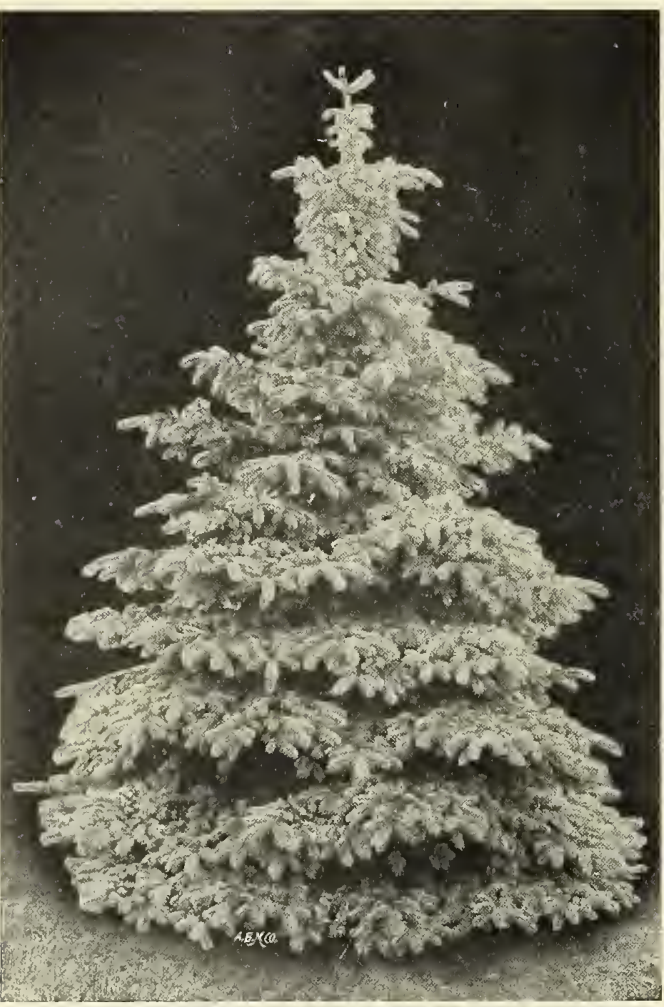

Picea Kosteriana-Koster's Blue Spruce. PICEA-Continued.

Picea var. elata. "L.r." Long, slender branches, widely separated, leaving the trunk of the tree largely exposed. Lower branches droop to the ground. $8 \mathrm{feet} \ldots \ldots \ldots \ldots \ldots \ldots \ldots \ldots \ldots \ldots \ldots$ Each $\$ 3.00$

5.00

"var. inverta (The Inverted Spruce). "M." It forms a pillar-like tree, which standing alone is a dominant feature in the landscape.

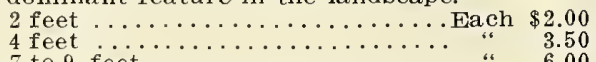

"var. pyramidalis (Pyramidal Spruce). “M.m.' Deep green foliage on branches ascending at narrow angles, forming a narrow conical tree. Very useful and effective.

4 to 5 feet $\ldots \ldots \ldots \ldots \ldots \ldots \ldots$ Each $\$ 2.50$

3.50

"var. pumila. "V.d.s." A pretty little dwarf form not over 2 to 3 feet in height. Excellent where dwarf growth is desired.

18 inches ........................... $\$ 1.50$

"var. pygmaea (Pygmy Spruce). "V.d.s." One of the dwarfest of the Spruces, attaining a height of about 2 feet only. Short branches with stiff, small foliage.

12 to 15 inches ............. Each $\$ 1.50$

"var. nigra (Black Spruce). "L.r." A good native tree, with darker and shorter leaves than the White Spruce. Hardy and valuable in seashore planting.

2 to 3 feet

Each $\$ 1.00$

3 to 4 feet

1.50

"orientalis (Eastern Spruce). Resembling a fineleaved Norway Spruce, but much more elegant than the latter, of graceful form and dark. attractive foliage.

18 inches

Each $\$ 0.75$

$21 / 2$ feet

2.00
Picea polita (Tiger-Tail Spruce). "M.m." A tree forming a dense, broad pyramid, with stout branches and very stiff, sharp leaves. A pleasing shade of green.

$21 / 2$ feet ................................. $\$ 2.00$

" pungens (Colorado Spruce). "L.r." Stiff, pungent foliage and clusters of cones. No Evergreen tree can excel it, as it has the advantage of growing vigorously where many Evergreens fail Withstands the coldest seasons.

2 feet ................................ $\$ 1.00$

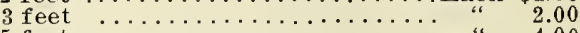

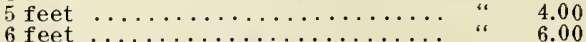

8 to 9 feet. Specimens ......... " 10.00

" var. glauca (Colorado Blue Spruce). Habit of growth similar to that of the preceding. Foliage of a rich blue or sage color. Extremely hardy.

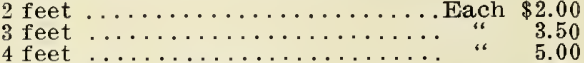

4 feet 5 to 7 feet. Specimens ...... " $\quad \begin{aligned} & 5.00 \\ & 4 \ldots\end{aligned}$

“ var Kosteriana (Koster's Blue Spruce). Foliage silvery blue. The bluest strain that can be selected; grafted from the famous Koster variety.

12 to 18 inches $\ldots \ldots \ldots \ldots \ldots$ Each $\$ 1.00$

2 feet $\ldots \ldots \ldots \ldots \ldots \ldots \ldots \ldots \ldots$ " 2.50

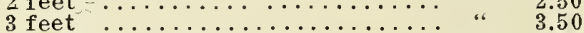

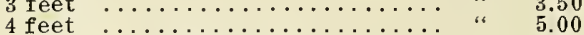

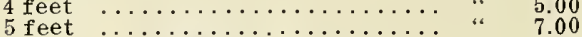

6 to 7 feet. Specimens $\ldots \ldots \ldots$ " 12.00

\section{Pinus - Pine}

Pinus Austriaca (Austrian, or Black Pine). "L.r." A robust growing variety, with long, dark green, stiff needles. Does well on all soils.

2 feet $\ldots \ldots \ldots \ldots \ldots \ldots$. . . . . . . $\$ 1.00$

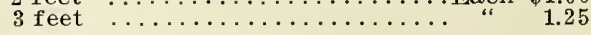

Cembra (Swiss Stone Pine). "S.s." Of thick, regular growth, foliage resembling the White regular growth, foliage

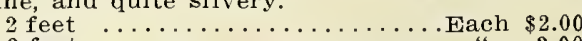
3 feet $\ldots \ldots \ldots \ldots \ldots \ldots \ldots \ldots \ldots \ldots \ldots$ " 3.00

" divaricata; syn. Banksiana (Jack Pine). "L.r." Grows on the thinnest and driest soils. It is one of the most rapid-growing Pines, with an irregular, picturesque top.

3 to 4 feet ........................ $\$ 0.75$

" Massoniana, or Thunbergii (Japanese Sea Shore Pine). "M.m." A rare but very beautiful species. Spreading growth. Bright green foliage, 3 to 4 inches long. Very hardy and particularly good for seashore planting.

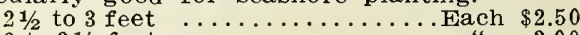
3 to $31 / 2$ feet $\ldots \ldots \ldots \ldots \ldots \ldots \ldots \ldots \ldots \ldots$ " 3.00

" montana (Dwarf Mountain Pine). "D.s." Coarser and more upright than the following. Very hardy and excellent for massing on hillsides or for seashore planting. Attains a height of about 8 feet.

15 to 18 inches ............. Each $\$ 1.00$ $11 / 2$ to 2 feet ................... 1.50

2 to 3 feet, bushy ........... " 2.50

"Mughus (Dwarf Mugho Pine): "D.s." Of the highest value where a low, dense, spreading growth is desired. Very dark foliage and extremely hardy.

18 inches $\ldots \ldots \ldots \ldots \ldots$ Each $\$ 1.00$ 2 feet ............... " 2.00

" ponderosa (Heavy-wooded Pine). "L.r." One of the tallest of the Pines, attaining a height of more than 100 feet. Leaves 6 to 8 inches long and silvery green.

2 to $21 / 2$ feet .............................. $\$ 1.50$

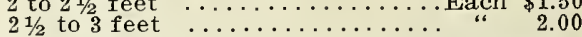

" rigida (Pitch Pine). "L.r." A native tree of pyramidal growth. Thrives well on poor soil. 3 to 4 feet $\ldots \ldots \ldots \ldots \ldots \ldots \ldots \ldots \ldots$ Each $\$ 0.75$

" resinosa (Red Pine). "L.r." A native Pine, with red bark and light green foliage growing in whorls. Useful for its timber.

3 feet .............................. $\$ 2.00$

" sylvestris (Scotch Pine). "L.r." Foliage much more silvery than the Austrian. It is very desirable for mass and shelter planting.

3 feet $\ldots \ldots \ldots \ldots \ldots \ldots \ldots \ldots \ldots$. . . . . $\$ 1.00$ 
PINUS-Continued.

" Strobus (White Pine). "L.r." The most valuable of all Evergreens for timber purposes. with its light silvery foliage, is always highly ornamental. In age this Pine is most impressive. Useful for hedges, as it can be clipped like a shrub.

$\begin{array}{rr}21 / 2 \text { to } 3 \text { feet } \ldots \ldots \text { Each } & \$ 0.50 \\ 4 \text { feet } \ldots \ldots \ldots \ldots & 1.00 \\ 5 \text { feet } \ldots \ldots \text { ". } & 1.25 \\ 6 \text { to } 8 \text { ft. Specim's " } & 3.00\end{array}$

"var. nana. "V.D." A low, balllike growth, not over 2 feet. Rare.

18 to 24 inches ... Each $\$ 2.00$

\section{Pseudotsuga - Douglas Spruce}

Pseudotsuga Douglasii "L.r." A fine, long-lived tree from the Rocky Mountains, where it grows in great quantity. The foliage is soft and brilliant green in color, with bluish tint when young. It is of the most vigorous and symmetrical growth.

3 feet $\ldots \ldots \ldots$ Each $\$ 1.00$

4 feet $\ldots \ldots \ldots \ldots$ " 1.50

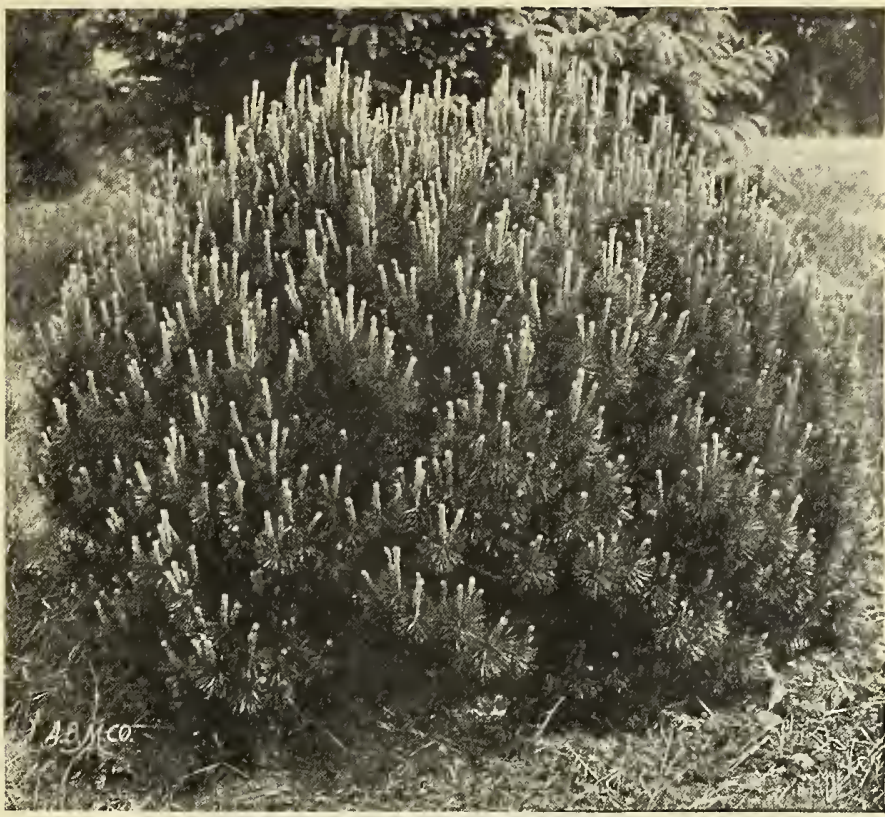

\section{Retinospora - Chamaecyparis or}

\section{Japanese Cypress}

Retinospora flifera (Thread-branched Japanese Cypress). "M.s." Slender, string-like, bright green foliage, drooping in long filaments. Graceful and pyramidal habit.

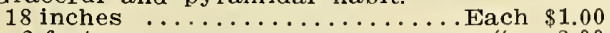
2 feet $\ldots \ldots \ldots \ldots \ldots \ldots \ldots \ldots \ldots \ldots \ldots \ldots \ldots \ldots \ldots \ldots$ " 2.00

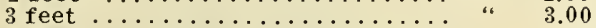

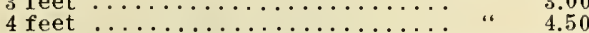

"var. aurea (Golden Thread-branched Cypress). "M.s." A lovely, bright golden form of the preceding; equally hardy.

12 to 15 -inch spread ...........Each $\$ 1.50$

“ obtusa (Obtuse-leaved Japanese Cypress). "M.s." Graceful, fern-like foliage, distinct and beautiful. Hardy.

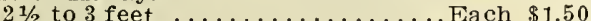

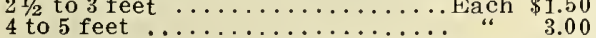

"var. nana. "V.D.s." One of the best and hardiest of the dwarf Evergreens. Intensely dark, shell-like leaves; very unusual. A most elegant Evergreen shrub.

Each $\$ 1.50$

“ var. gracilis. "D.s." A dwarf variety, rather irregular in habit, with short, dark green foliage Very bushy and desirable.

$11 / 2$ to 2 feet .......................... $\$ 1.50$

2 to $21 / 2$ feet $\ldots \ldots \ldots \ldots \ldots \ldots \ldots \ldots$. $\$ 2 . \ldots \ldots$

3 feet $\ldots \ldots \ldots \ldots \ldots \ldots \ldots \ldots \ldots \ldots \ldots$ " $\quad 3.00$

" pisifera (Pea-fruited Japanese Cypress). "L.m." Resembles $R$. obtusa, but with more slender and gracefully drooping branches.

2 feet .............................. $\$ 1.50$

3 feet $\ldots \ldots \ldots \ldots \ldots \ldots \ldots \ldots \ldots \ldots \ldots \ldots \ldots$

4 feet ................... " 3.50

" pisifera aurea. "L.m." A fine pyramidal, bright golden form, very hardy, distinct and graceful. 2 feet $\ldots \ldots \ldots \ldots \ldots \ldots \ldots \ldots$................. $\$ 1.50$

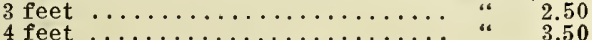

"var. plumosa (Plume-like Japanese Cypress). "L.m." One of the hardiest and best. Delicate glaucous foliage.

2 feet .......................... $\$ 1.00$

3 feet, bushy $\ldots \ldots \ldots \ldots \ldots \ldots \ldots \ldots$ " 2.50

4 feet ..............

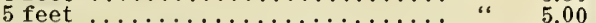

"var, plumosa aurea. "L.m." A striking, fine form of the above, and very hardy. Brilliantly golden throughout the season. One of the most desirable.

2 feet .................. Each $\$ 1.00$

3 feet, bushy .................

4 feet $\ldots \ldots \ldots \ldots \ldots \ldots \ldots \ldots \ldots$ ، $\quad 3.50$

5 feet ................. 5.00

" squarrosa. "M.m." Dense in growth, with steelcolored foliage. Requires a sheltered position. A well-known plant of this variety, is exceedingly beautiful.

2 feet ............................. $\$ 2.00$

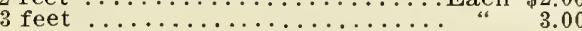

\section{Sciadopitys - Umbrella Pine}

Sciadopitys verticillata. "L.m." A Japanese Evergreen tree, with perfectly upright trunk and horizontal branches, bearing whorls of shining green, very broad, flat needles, lined with white on the under side. It is of slow growth at first, but makes finally a large tree. A rare tree even in Japan.

18 to 24 inches.

Each $\$ 3.00$

\section{Taxus - Yew}

Taxus var. fastigiata (Irish Yew). "M.s." Deep green foliage, with perfect columnar form Requires shelter until well established.

2 to 3 feet. Specimens .......... Each $\$ 2.00$

4 to 5 feet. Specimens.......... " 3.50

"var. repandens. "D.m." A graceful, spreading form, rich in color and very hardy. Rare but very desirable.

18-inch specimens ........... Each $\$ 2.00$

baccata (European Yew). "M.s." Slow-growing, with short stems and very bushy head; densely branched, thickly covered with drooping, somber green leaves.

3 to 4 feet

Each $\$ 3.50$

var. Washingtoni. "D.s." The best of the goldn Yews; handsome and rare.

18 inches

Each $\$ 2.00$

Canadensis (American Yew). "D.s." A low, weeping, broad, spreading bush, dark green foliage and crimson berries. Entirely hardy and very valuable.

18 inches ................Each $\$ 1.50$

cuspidata (Abrupt-leaved Japanese Yew). "S.m." Upright growth and dense, very dark foliage. Valuable because it is especially hardy and rich in appearance.

1 foot .................. Each $\$ 1.25$

$11 / 2$ to 2 feet $\ldots \ldots \ldots \ldots \ldots \ldots \ldots \ldots$ " 2.00

"var. brevifolia. "D.s." A very handsome form of the above. Spreading and very hardy. We consider it the best variety to plant in New England.

1 foot

$11 / 2$ to 2 feet

Each $\$ 1.25$ 2.00 


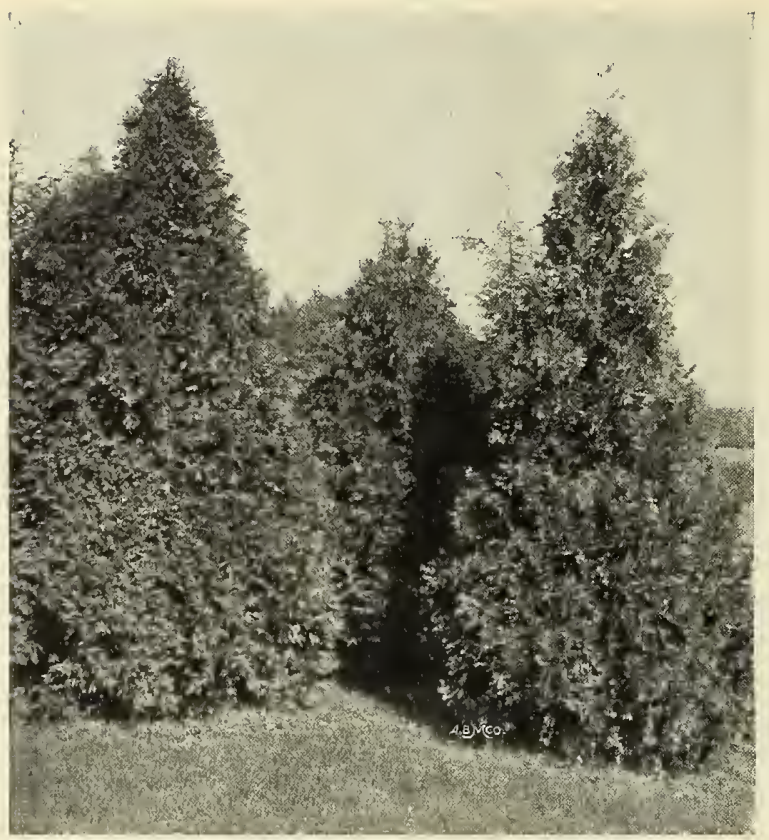

Thuya occidentalis-American Arborvitae.

\section{Thuya - Arborvitae}

Thuya occidentalis (American Arborvitae). "M.r." of conical form and rapid growth. Used largely for hedges.

2 feet $\ldots \ldots \ldots \ldots \ldots \ldots \ldots \ldots \ldots \ldots \ldots \ldots$ Each $\$ 0.40$
3 feet $\ldots \ldots \ldots \ldots \ldots \ldots \ldots \ldots \ldots \ldots \ldots \ldots \ldots \ldots \ldots \ldots \ldots$

4 feet ............... " 1.00

" vax. alba (Silver-tipped. or Queen Victoria Arborvitae). "M.m." Tipped with white; distinct.

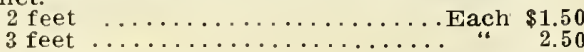

"var. Geo. Peabody. "M.r." A dense-growing golden variety, holding its color all summer. 3 feet ............................. $\$ 1.50$ 4 feet $\ldots \ldots \ldots \ldots \ldots \ldots \ldots \ldots \ldots \ldots \ldots \ldots$ " 2.50

"var. globosa (Globe-headed Arborvitae). "V.d.s." Growing in low, thick, globe form, with attractive foliage. Very distinct.

12 inches .............................. $\$ 0.50$

“ var. Hoveyi (Hovey's Arborvitae). "D.s." A slow-growing form, with golden-green toliage. 18 inches ................................ $\$ 0.75$ 2 feet .................. 1.00

"var. lutea. "M.m." Bright yellow foliage on terminal branches.

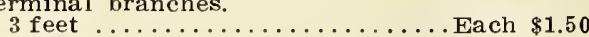

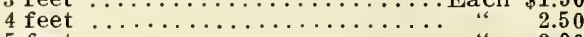

5 feet $\ldots \ldots \ldots \ldots \ldots \ldots \ldots \ldots \ldots \ldots \ldots$ " 3.00

" var. minima (Little Gem). Very dwarf, not making more than an inch of growth annually. Forms a spreading mat of foliage.

8 to 10 inches ................ Each $\$ 1.00$

“6 var. pyramidalis (Pyramidal Arborvitae). "M.r." Its forni is very much like the Irish Juniper. The foliage is light green and compact.

2 feet ................. Each $\$ 0.50$

3 feet

4 feet

1.50
Thuya var. Rosenthali. "M.m." A distinct tree of fine habit and growth.

2 feet. Specimens ........Each $\$ 1.00$

“ var. Sibirica (Siberian, or Wareana Arborvitae). "M.r." A low-growing, dense form. Its beautiful bluish-green foliage gives it a distinct character. It is one of the hardiest.

18 inches $\ldots \ldots \ldots \ldots \ldots \ldots$ Each $\$ 0.50$

2 feet $\ldots \ldots \ldots \ldots \ldots \ldots \ldots \ldots \ldots \ldots \ldots \ldots \ldots \ldots \ldots \ldots$
3 feet $\ldots \ldots \ldots \ldots \ldots$

" var. spiralis. "M.m." A tree growing in spiral form, with dark green foliage. Rare.

18 to 24 inches ......... Each $\$ 0.75$

“ var. Tom Thumb. "V.D.s." Foliage resembling a Heath. Useful where lowgrowing forms are needed. Hardy.

12 inches $\ldots \ldots \ldots \ldots \ldots \ldots \ldots$ Each $\$ 0.50$

" var. Vervaeneana. "M.m." A fine, hardy variety, in which the green is singularly intermixed with a predominating shade of golden yellow. predominating 18 inches $\ldots \ldots \ldots \ldots \ldots \ldots \ldots$ Each $\$ 0.50$ 2 feet ................ ${ }^{1.00}$

\section{Tsuga - Hemlock}

Tsuga Canadensis (Hemlock Spruce) "I r" A graceful tree, with loose, open growth and Yew-like foliage. It can be kept in dense form if pruned. Prefers moist soil.

2 feet $\ldots \ldots \ldots \ldots \ldots \ldots$ Each $\$ 0.75$

$21 / 2$ to 3 feet .......... “ 1.25

" var. Sargenti (Sargent's Weeping Hemlock). A flat-topped form with spreading branches and drooping branchlets. Very rare and desirable.

18 inches ............. Each $\$ 2.00$

We will quote special prices on young Evergreens for forest planting, i. e., Pines, Spruces and Firs. Also on acclimated hybrid Rhododendrons, Rhododendron Maximum and Mountain Laurel, which we can furnish in carload lots. 


\section{Hardy Evergreen Shrubs, Plants and Vines}

Evergreen Shrubs, like Evergreen Trees, transplant well in the Spring as soon as the ground is open, and generally as late as June 1 st. Also during the period beginning August 1st and continuing until the ground becomes frozen.

\section{Andromeda}

(A family of exquisite plants, all preferring deep, moist soil).

Andromeda Catesbaei. (See Leucothoe Catesbaei).

" floribunda (Lily of the Valley Tree). "D.s." Flowers in large, white panicles, over a dense dark mass of Evergreen foliage. The buds are formed in the Fall.

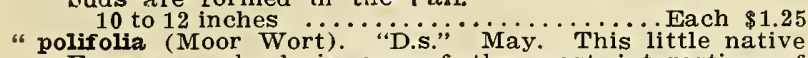
Evergreen shrub is one of the most interesting of plants. The long, narrow leaves are silvery white beneath, and bright glaucous above. The rosy-pink, waxy flowers are urn-shaped, in clusters.

8 to 12 inches ...................... Each $\$ 0.50$

\section{Arctostaphylos Uva-Ursi - Bearberry}

Arctostaphylos Uva-Ursi. A trailing plant, with rich, glossy leaves. Excellent for covering rocky or dry places. Of rapid growth and very hardy.

Well-rooted young plants.............Each $\$ 0.50$

\section{Azalea}

Azalea amoena (Lovely Azalea). "D.s." A dwarf, bushy shrub, foliage turning to a bronze brown in Winter. Covered in May with enveloping masses of rich, purplish-red double flowers.

12 to 15 inches ................... Each $\$ 1.25$

" Hinodegiri. "D.s." Very hardy. Follage much similar to that of the preceding, but flowers are bright red.

Bushy plants .................... Each $\$ 1.25$

\section{Berberis aquifolia \\ (See Mahonia).}

\section{Buxus - Boxwood}

An Evergreen shrub with close-growing, oval, dark, shining foliage. Stands pruning very well; thrives in almost any well-drained soil, and best in a partially shaded position. Busus, Pyramidal Form. Fine specimens, closely trimmed, highly desirable for placing in tubs or planting in formal positions in the garden.

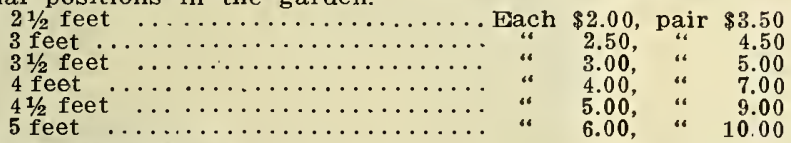

Buxus, Standard rorm.

$11 / 2$ foot stem, 10 inch crown...... Each $\$ 1.50$, pair $\$ 2.50$ $21 / 2$ foot stem, 18 inch crown........ 2.50 , " 4.50 $21 / 2$ foot stem, 24 inch crown........

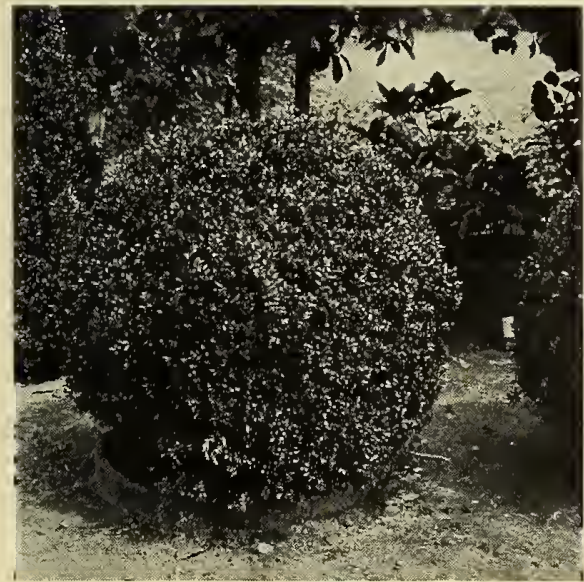

Buxus, Bush Form. Useful for window boxes, or for bordering walks, or for shrubbery planting.

8 to 10 inches

10 to 12 inches

12 to 15 inches

15 to 18 inches

18 to 24 inches

24 to 30 inches.
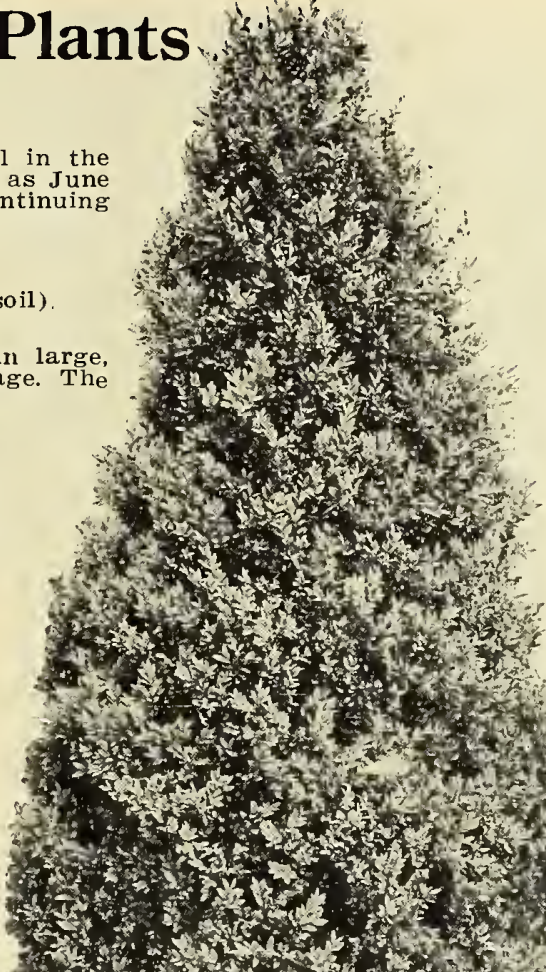

3

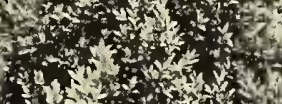

$+12$
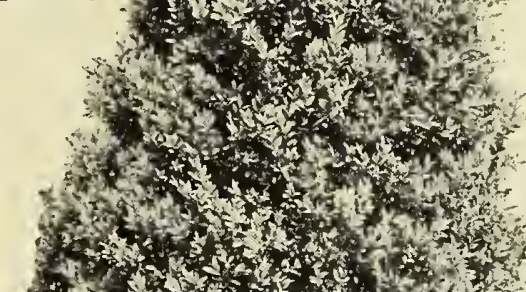


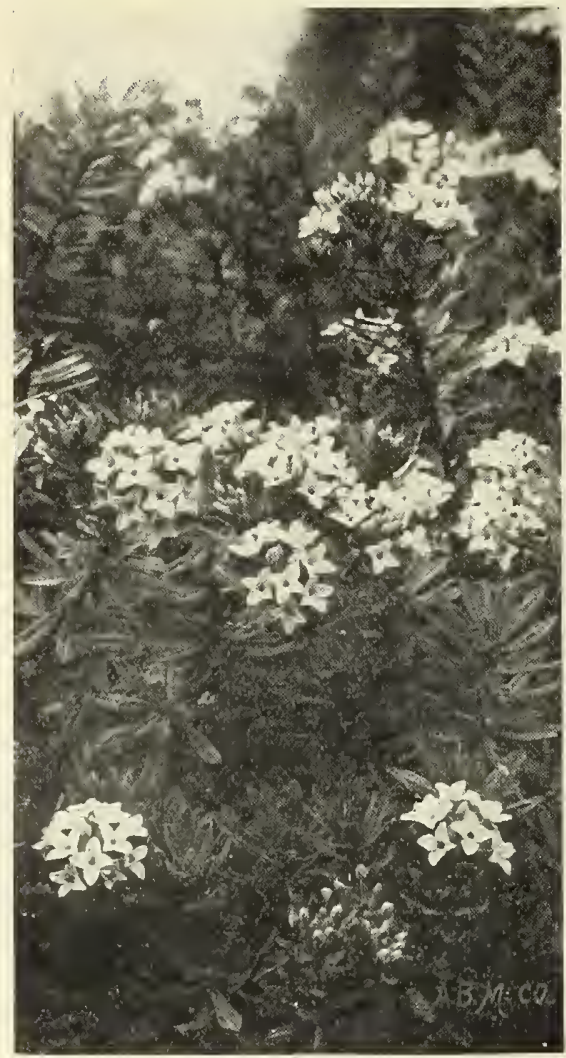

Daphne cneorum

\section{Daphne - Garland Flower}

Daphne cneorum. An evergreen, hardy plant, with closely set, glossy, narrow leaves. It begins in May to bloom, and its round clusters of bright pink, highly fragrant blossoms, much resembling the beautiful Mayflower of our woods, are borne in great profusion.

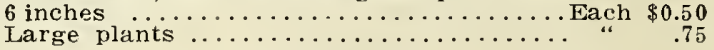

\section{Euonymus}

Euonymus radicans (Creeping Euonymus), "V.D." " A glossy, dark-leaved vine; or it will form a spreading shrub where it cannot climb. Valuable for covering walls, to which it clings.

2 year ............................. $\$ 0.25$, doz. $\$ 2.50$

- var. variegata (Variegated Creeping Euonymus). Very distinctly variegated with white, yellow and pink shades. An equally strong grower, and very attractive on low walls.

2 year ................Each $\$ 0.30$ doz., $\$ 3.00$

"var. Vegetus, Round-leaved. A variety that is much sought by all who have seen it. In habit it is more spreading than the type and of more rapid growth. Leaves broad, nearly round, and of a rich, glossy.green. 2 vears ......................... $\$ 0.35$, doz. $\$ 3.50$

\section{Hedera - Ivy}

Hedera Felix (English Ivy). Its broad, glossy, dark leaves retain their beauty all winter if planted on the eastern and northern sides of buildings, away from the sun.

Large plants ............ Each $\$ 0.50$, doz. $\$ 5.00$

\section{Ilex - Holly}

Ilex crenata. "D.s." A rare but very handsome and useful low Evergreen of bushy habit. Foliage resembles that of the Boxwood. A good hedge plant for sheltered places, and excellent for massing with deciduous shrubs.

$11 / 2$ to 2 feet ................................. $\$ 1.50$

\section{Kalmia - Laurel}

Kalmia angustifolia (Lambkill). Light green, narrow leaves, with close clusters of dark red flowers.

Each ...................... \$0.50

"latifolia (Mountain Laurel). This lovely Evergreen shrub is hardy anywhere in New England. It prefers deep, leaf-mold soil, but grows wherever it will not dry out in summer. The beautiful pink and white flowers are of unique shape and aspect, borne in large clusters over broad, glossy foliage.

15 to 18 inches....... Tach $\$ 1.00$, doz. $\$ 10.20$

2 to 3 feet............................... $\$ 2.00$

Prices on carload lots on request.

\section{Bay Trees - Laurus Nobilis}

(Sweet Bay)

This and the Boxwood are the most useful of all Evergreen tub plants. It endures abuse and neglect and considerable frost. Excellent for decorating halls, porches, etc.

Standard Form-..

32 inch stem, 26 inch crown

Each $\$ 8.00$, pair $\$ 15.00$ 42 inch stem, 30 inch crown

Each $\$ 10.00$, pair, $\$ 18.00$

42 inch stem, 36 inch crown

Each $\$ 13.00$, pair $\$ 22.00$

Pyramidal Form-

5 feet ............... $\$ 6.00$, pair $\$ 10.50$ 6 feet $\ldots \ldots \ldots \ldots \ldots$ " 11.00 , " 20.00

\section{Leucothoe}

Ieucothoe Catesbaei (Andromeda Catesbaei). Foliage thick, heavy and pointed. A shining green in Summer, the branches arching gracefully. T'he showy spikes of white flowers open early in shaded spots. Good for massing under trees, or with shrubbery, Rhododendrons, Mountain Laurel or Azaleas.

12 inches high, bushy plants

Each $\$ 0.50$, doz., $\$ 5.00$

\section{Mahonia}

Mahonia, or Berberis aquifolia (Ashberry). "D." m." Its large, spiny leaves, which turn scarlet in Fall, are much like those of the famous English Holly, and its bright yellow flowers in May are effective. Good in shady spots. 12 to 18 inches ................................. $\$ 0.50$ 18 to 24 inches $\ldots \ldots \ldots \ldots \ldots \ldots \ldots$ " .75

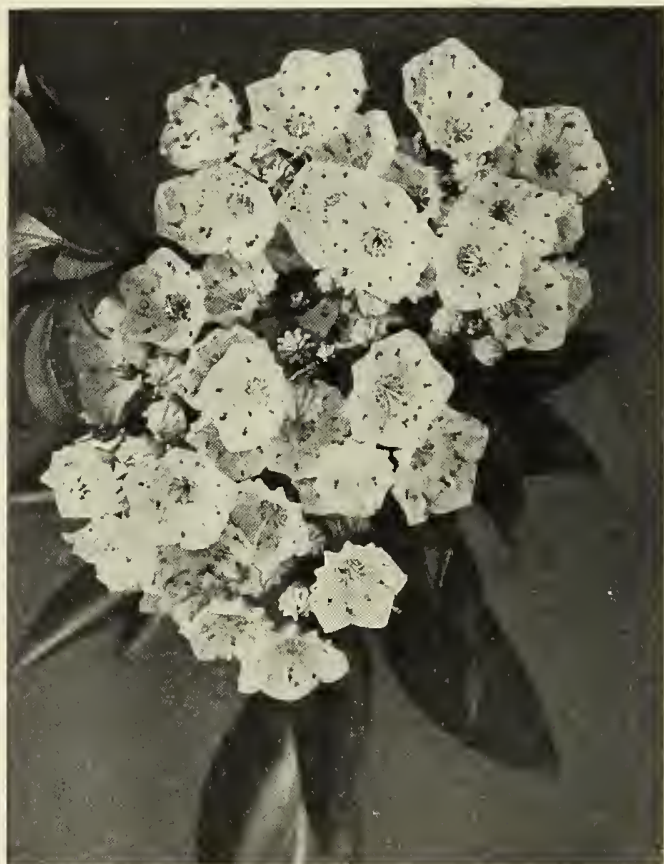

Kalmia latifolia-Mountain Laurel. 


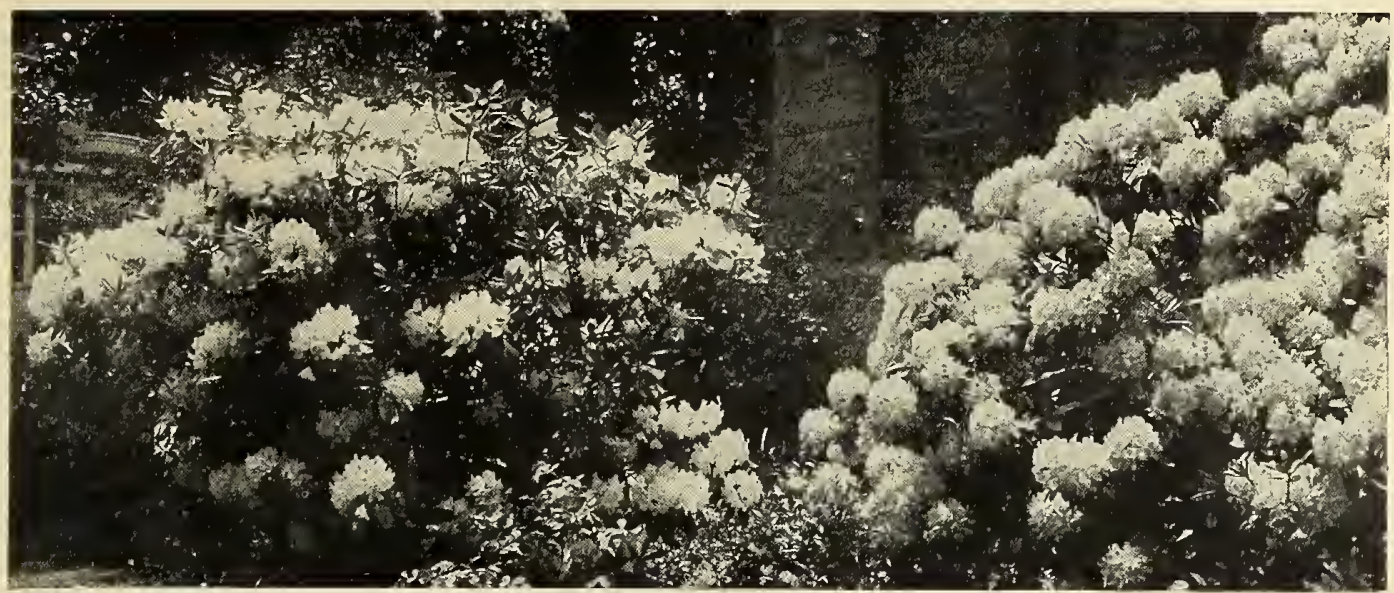

Rhododendrons.

\section{Rhododendrons}

We make annually large importations of hybrid Rhododendrons, and carry always in stock a complete variety of those reliably hardy in this elimate. We positively handle no variety of questionable hardiness.

Ehododendron Catawbiense. This is a native close-growing form, with handsome foliage and large trusses of deep rose flowers. A splendid variety to group with high-colored forms, as its foliage effect can be depended upon. Extra fine bushy plants.

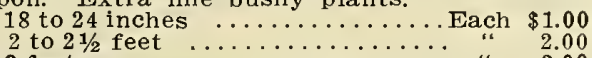

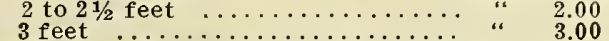

"Catawbiense grandiflora. The foliage effect is similar to the preceding, but of darker, richer green. Flowers deep, rosy purple, borne in great profusion.

$11 / 2$ to 2 feet..$\ldots \ldots \ldots \ldots \ldots$ Each $\$ 1.50$ $21 / 2$ feet $\ldots \ldots \ldots \ldots \ldots \ldots \ldots \ldots \ldots \ldots \ldots$ " $\$ 3.00$ 3 feet $\ldots \ldots \ldots \ldots \ldots \ldots \ldots \ldots \ldots \ldots \ldots \ldots \ldots \ldots \ldots \ldots \ldots$ " 4.00

"Catawbiense alba. Same as above, but with pure white flowers. 18 to 24 inches ............. Each $\$ 1.50$

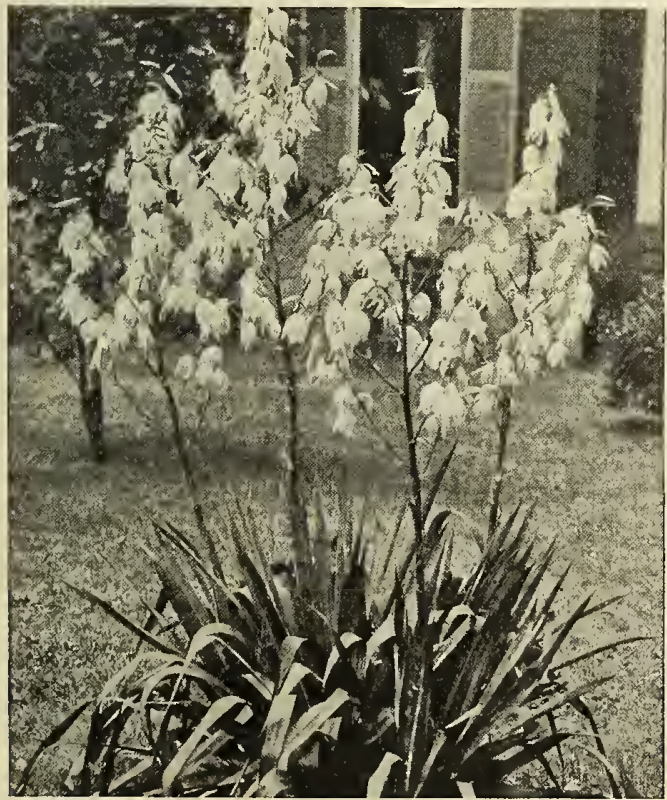

Yucca flamentosa.

\section{ALPINE RHODODENDRONS}

Rhododendron ferrugineum (Alpine Rose) "D." June and July. Flowers of a beautiful scarlet color. marked with yellow dots: oblong, shin-

hirsutum. Much like the preceding, but with

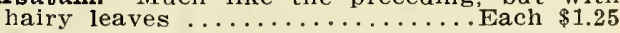

" punctatum. A beautiful native variety of dwarf habit; producing pale rose-colored flowers in great profusion. .............Each $\$ 1.25$

"Wilsoni. A beautiful dwarf variety, with a profusion of pale lavender flowers. ... Each $\$ 1.50$

" maximum (Great Bay). "L." July. This is the noblest of all our native shrubs, and is absolutely hardy from Vermont to Georgia. It has the most beautiful foliage of any kind of Rhododendrons; it being about twice as large as that of any other sorts, and very thick and smooth. Forms a round broad bush, from 6 to $15 \mathrm{ft}$. tall. Flowers pink and white. 2 to 3 feet, bushy ........................ $\$ 1.50$ 3 to 4 feet bushy

4 to 5 feet, bushy

5 to 6 feet bushy

By the carload, prices on application.

\section{NAMED HYBRID RHODODENDRONS}

The varieties we list have been well tested, and we confidently offer them as hardy in New England.

12 to 18 inches, well budded.......\$1.00 $\$ 10.00$ 18 to 24 inches, well budded.......... $1.50 \quad 15.00$ 24 to 30 inches, well budded........ 2.00 20.00 30 to 36 inches, well budded ..... $3.00 \quad 30.00$

Abraham Iincoln. Rosy crimson.

Album elegans. Blush, changing to white.

Atrosanguineum. Intense blood red.

Boule de Neige. Pure white; very hardy.

Caractacus. Rich purplish crimson.

Charles Bagley. Cerise pink.

Charles Dickens. Dark scarlet.

Delicatissimum. Blush white, edged pink.

Everestianum. Rosy lilac, spotted red.

General Grant. Crimson pink.

Gigantewm. Bright rose

Gloriosum. White; bold flowers and good foliage.

F. F. Funnewell. Dark crimson.

John spencer. Clear violet rose.

Kettledrum. Very lively crimson.

Iady Armstrong. Pale rose, beautifully spotted.

Iady clermont. Red, shaded crimson.

IMrs. Milner. Rich crimson.

Farson's gloriosum. Pale lavender.

Farson's grandifiorum. Bright carmine.

President Iincoln. Reddish purple.

Roseum elegans. Vivid rose; beautiful.

\section{Yucca}

Tucca filamentosa (Spanish Bayonet). Narrow, sword-like foliage, giving a rounded, bristlelike effect. Tall, showy spikes of creamy flowers on a stem 3 to 4 feet high. Each ..............\$0.30 doz. \$3.00 


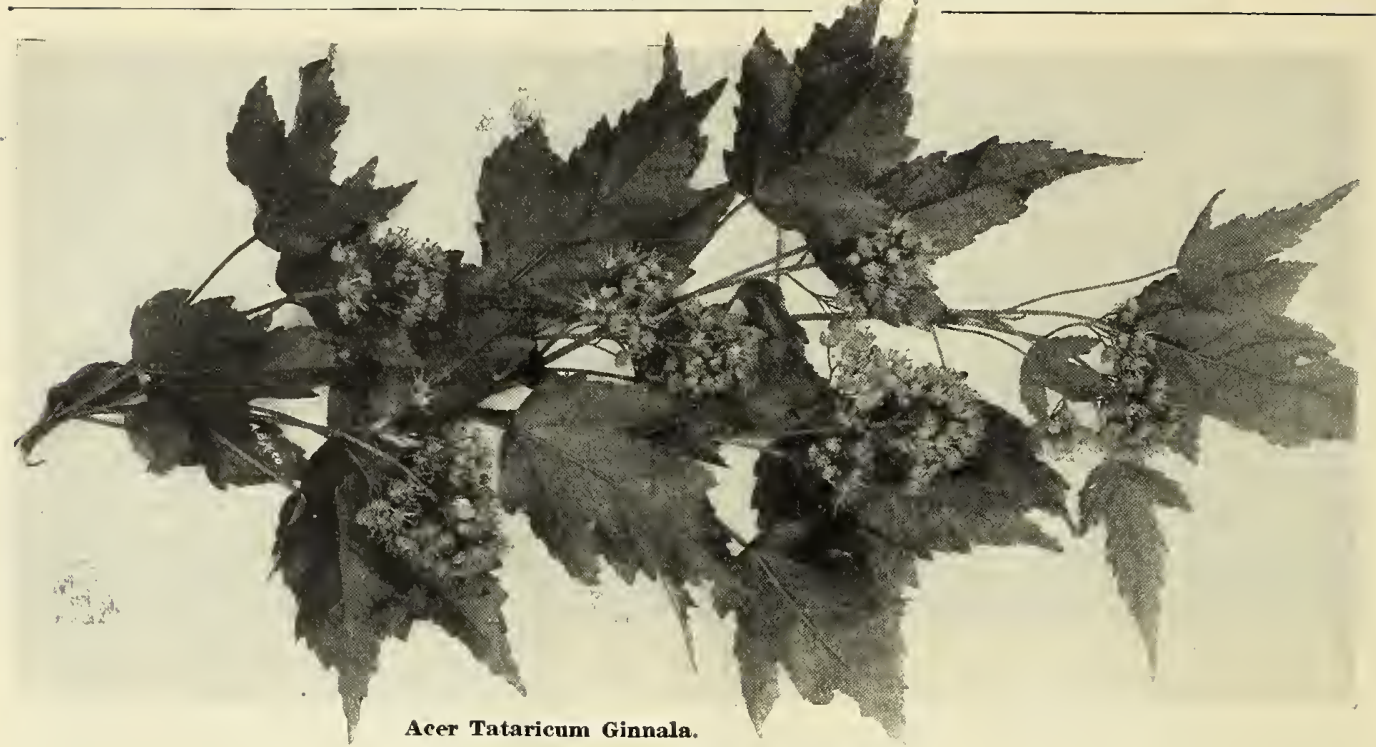

\section{Deciduous Trees}

"When we plant a tree we are doing what we can to make our planet a more wholesome and happier dwelling place for those who come after us if not for ourselves."-Holmes.

We name in this catalogue only such varieties of trees as are hardy in the latitude of New England, and of practical value to the planter.

NOTE.-The following letters are used to designate ultimate height of trees at maturity: "A." 50 feet and upward; "B," 20 to 40 feet; "C," 10 to 20 feet. Denoting rapidity of growth: "r," rapid:

"m," medium; and "s," slow.

\section{Acer - Maple}

One of the most widely known class of trees. They are comparatively free from insect pests, and for street and lawn planting are invaluable.

Acer dasycarpum (White or Silver Maple). "A."

The most rapid growing of the Maples. 6 to 8 feet $\ldots \ldots \ldots \ldots \ldots \ldots \ldots \ldots \ldots$ Each $\$ 0.75$

1.00

Large specimens, from $\$ 1000$ to $\$ 25.00$ each.

" var. Wieri laciniatum (Wier's Cut-leaved Silver

Maple). "A." Its foliage is deeply cut and

is borne upon long, recurving, pendulous branches. "r."

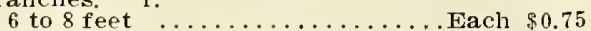
8 to 10 feet ....................... 1.00

" Tegundo (Ash-leaved Maple or Box Elder). "A." Growth rapid, regular and spreading; does well on a dry soil.

8 to 10 feet ................................. $\$ 0.75$

" Pennsylvanicum; syn. striatum (Striped-barked Maple or Moosewood). "C." Its bark is striped with green and white. Foliage broad and effective. "m." 5 to 6 feet ............................ $\$ 0.75$

" platanoides (Norway Maple). "A." Native of Europe. A large, spreading tree, with a more round compact form than the Sugar Maple. It is a very hardy, vigorous tree, and the best of all Maples for seashore planting, also one of the best for street purposes. 'm.'

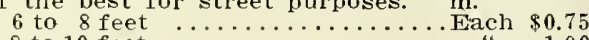

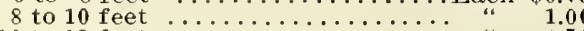

10 to 12 feet ............... " 1.50

“var. Schwedleri (Schwedler's Norway Maple). "B." The early foliage of this variety is a bright crimson, fading to purplish green. "m."

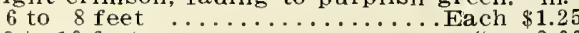

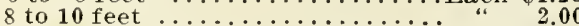

"var. Geneva (Geneva Maple) "B," Foliage dark green in spring, turning deep red in Midsummer. Irregular and spreading in growth

6 to 8 feet $\ldots \ldots \ldots \ldots \ldots \ldots \ldots$ Each $\$ 1.00$

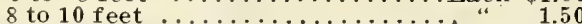

"Pseudo-platanus (Sycamore Maple). "B." A noble European variety of rapid, spreading growth: broad, deep green foliage.

8 to 10 feet ............................. $\$ 1.00$ "var, purpureum (Purple Sycamore Maple) "B" Foliage dark green on the upper surface and red purple underneath. "r."

6 to 8 feet ............................. $\$ 1.00$

" rubrum (Red, or Scarlet Maple). "B." Conspicuous in Spring for its masses of red blossoms, and in Fall for its glowing crimson foliage. "s."

8 to 10 feet $\ldots \ldots \ldots \ldots \ldots$ Each $\$ 1.50$

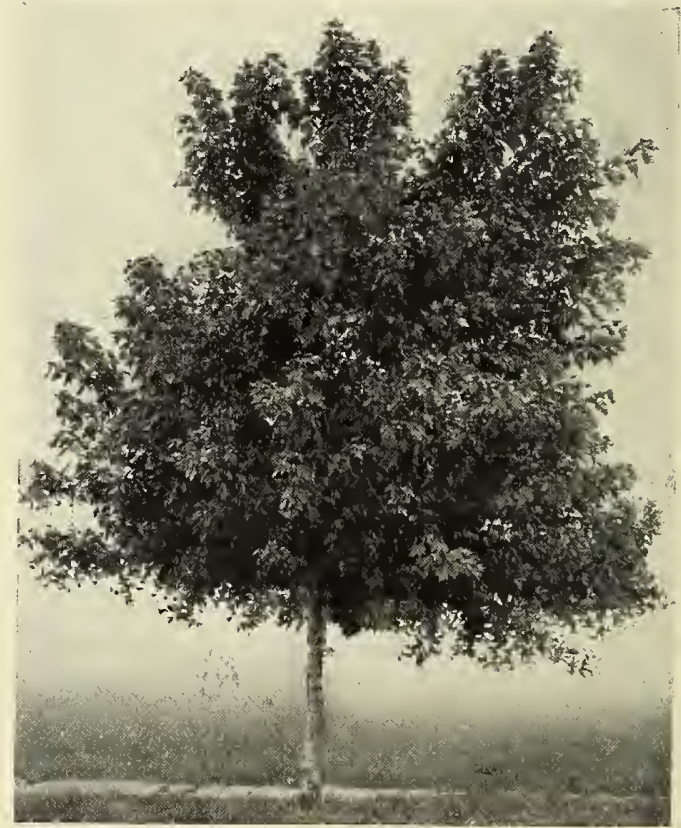

Acer dasycarpum-Silver Maple. 


\section{ACER-Continued.}

Acer Saccharum (Sugar, or Rock Maple). "A." Probably the most generally used of all shade trees. Its beautiful Autumn tints are familiar to all. "r."

8 to 10 feet $\ldots \ldots \ldots \ldots \ldots \ldots \ldots$ Each $\$ 1.00$

10 to 12 feet

1.50
1.75

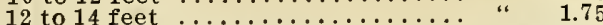

"spicatum (Mountain Maple). "B." Leaves rough and broad. Twigs deep red, with conspicuous clusters of pendulous greenish-yellow flowers. "r."

4 to 5 feet

Each $\$ 1.00$

5 to 7 feet ................. 1.25

“Tataricum var. Ginnala. "C." An exquisite miniature Maple from Siberia, with deeply notched leaves, which take on the most gorgeous tints of orange and crimson in October. A fit companion to the Japanese Maples. Very hardy and useful for screens and border hardy and "use

3 to 4 feet

4 to 5 feet

\section{Japanese Maples}

Acer polymorphum atropurpureum (Blood-leaved Japan Maple). "C." This is the most popular variety, with beautiful foliage of blood-red color. It is pretty all through the season, and is particularly fine when its foliage is fully expanded in early Spring. "s."

2 to $21 / 2$ feet ................ Each $\$ 1.50$

3 feet, bushy .................. " 2.00

" var. dissectum atropurpureum (Cut-leaved Purple Japanese Maple). "C." Branches drooping and generally twisted. Leaves finely cut and blood-red when young, changing to a deep purple. "s.'

18 to 24 inches ............ Each $\$ 2.00$

" palmatum aureum. "C." Very dwarf and compact and one of the hardiest. Foliage broad. and, a large part of Summer, a vivid golden yellow. "s."

18 to 24 inches

Each $\$ 1.75$

\section{Aesculus - Horse Chestnut}

Aesculus glabra (Ohio Buckeye). "B." Leaves smooth. Showy yellow flowers in May. Rapid and spreading in growth.

6 to 8 feet ........................... $\$ 1.00$

hippocastanum (The European, or White-flowering Horse-Chestnut). "A." Our well-known Horse-chestnut. Of large growth in deep soil. Flowering in May. "s."

6 to 8 feet ..................... $\$ 0.75$

8 to 10 feet ................ 1.50

" var. fl. pl. (Double White-flowered Horse-chestnut). "A." Double white flowers, larger than the type. "s."

6 to 8 feet ................Each $\$ 1.50$

“ rubicunda (Red-flowered Horse-chestnut). " $B$." The flowers are deep red, showing well against very dark foliage. "s."

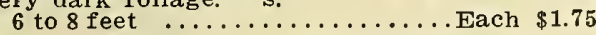

\section{Ailanthus - Tree of Heaven}

Ailanthus grandulosa. "B." From Japan. A rapid-growing tree, with feathery, tropical foliage. Does well on poor soil. "r."

6 to 8 feet .................... Each $\$ 0.75$

\section{Alnus - Alder}

Alnus glutimosa (European, or Black Alder).

A rapid grower, thriving in damp soils.

5 to 6 feet $\ldots \ldots \ldots \ldots \ldots \ldots \ldots$. Each $\$ 0.75$

"var. laciniata (Cut-leaved Alder). "B." From Northern France. Excellent as an individual specimen: of pyramidal habit, bearing dark deeply laciniated foliage. vigorous and hardy. "r."

4 to 5 feet

\section{Andromeda - Sorrel Tree}

Andromeda arborea, or Oxydendrum arboreum (Sorrel Tree). "C." A small, native tree, with shining, peach-like leaves, which assume brilliant Autumn tints. Flowers in long, terminal clusters, pure white and bell-shaped. "m."

3 feet

. Each $\$ 0.75$

\section{Aralia -- Angelica Tree}

Aralia spinosa (Hercules' Club). "C." Vigorous in growth. In August it bears large clusters of white flowers. It is used for tropical effects, in conjunction with other shrubs and low trees. "r."

3 to 4 feet $\ldots \ldots \ldots \ldots \ldots \ldots \ldots \ldots$ Each $\$ 0.50$

4 to 5 feet

" pentaphylla. (See Shrubs).

\section{Betula - Birch}

All Birches are attractive, whether of the upright or weeping forms. They thrive on poor soil and in exposed situations. Transplant best in early Spring.

Betula alba (European White Birch). "A." of rapid growth, with spray-like branches. Its white bark is effective in Winter. Particularly good among Evergreens.

4 to 6 feet

6 to 8 feet

Each $\$ 0.50$

. atropurpurea (Purple-leaved Birch). "B." A rather open growing tree, ${ }^{3}$ with deep purple foliage in Spring, fading to deep green in Mid-summer. "r."

4 to 5 feet ................ Each $\$ 1.00$

" var. fastigiata (Pyramidal Birch). "B." In growth fastigiate, like the Lombardy Poplar. Bark white. "r."

5 to 6 feet ............... Each $\$ 1.25$

" var. pendula laciniata (Cut-leaved Weeping Birch). "B." One of the best known trees in cultivation. Of tall, slender growth, with finely cut foliage borne upon drooping branches almost perpendicular in habit; bark silvery white. "r."

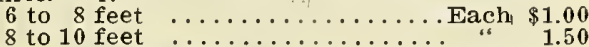

“ var. pendula Youngii (Young's Weeping Birch). "B." When fully grown a most attractive tree. Its branches are irregular and bend toward the ground. "m."

4 to 5 feet $\ldots \ldots \ldots \ldots \ldots \ldots \ldots$ Each $\$ 1.50$

ta (Sweet, or Black Birch). "A." of large well-shaped growth, with dark brown, spicy bark and broad foliage. "r."

4 to 5 feet ......................... $\$ 0.75$

"Iutea (Yellow Birch). "A." Somewhat like lenta, but with yellow bark.

Each $\$ 0.75$

" nigra, or rubra (Red Birch). "B." A splendid tree and most unique, especially for its shaggy layers of buff-colored bark, which are constantly peeling off. The younger branches are a deep brownish-red. Habit broadly pyramidal and foliage glossy. "m."

3 to 4 feet ........................... $\$ 0.75$

" papyracea (Canoe, or Paper Birch). "A." Bark silvery white and smooth. Very effective among Evergreens. "r."

6 to 8 feet .................Each $\$ 0.75$

" populifolia (American Gray, or Poplar Birch). "B." Our native Birch, common along every roadside, where its white bark gives it promnence. A picturesque tree. "r."

6 to $8 \mathrm{feet} \ldots \ldots \ldots \ldots \ldots \ldots \ldots$ Each $\$ 0.60$

\section{Caragana - Pea Tree}

Caragana var, nendula. An attractive small weeping tree, with yellow, Pea-shaped flowers in clusters.

6 to 7 feet

Each $\$ 1.50$

\section{Carpinus - Hornbeam}

Carpinus Americana (American Hornbeam). "B." Our native species, very similar in growth to the Beech, but inclined to grow in shrub form. "s."

3 to 4 feet ...............Each $\$ 0.50$

Betulus (European Hornbeam). "B." Foliage thick and "well adapted for making a dense 3 to 4 feet

Each $\$ 0.50$

\section{Castanea - Chestnut}

(See under Nut Trees). 


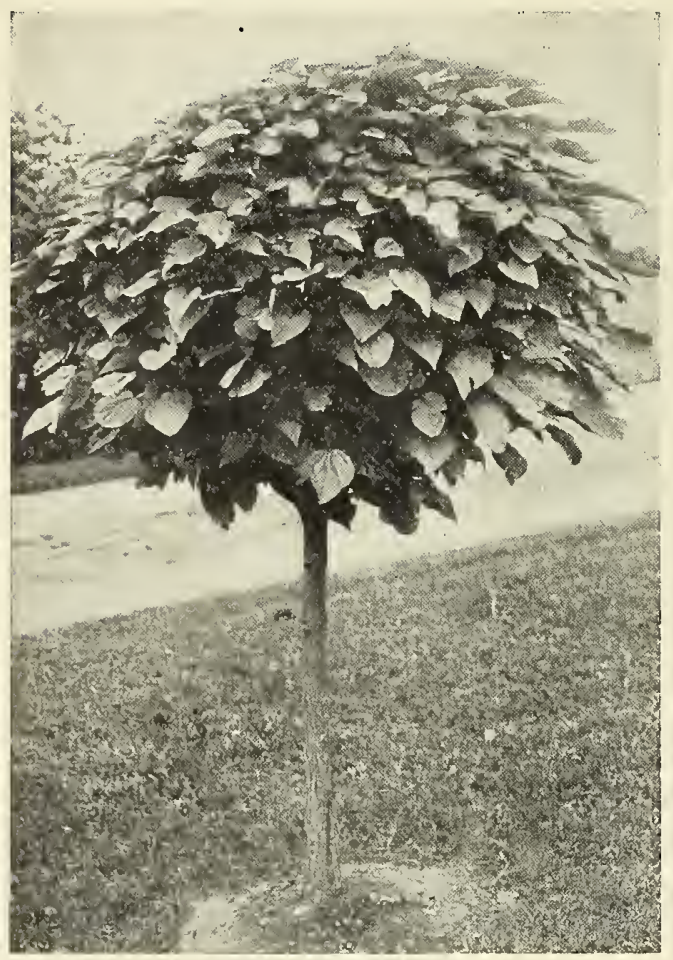

Catalpa Bungej.

\section{Catalpa}

Catalpa Bungei. "D." From China. A standard tree growing from 8 to 10 feet high, forming a dense head with foliage large and glossy. It is usually grafted on high stems.

7 to 8 feet .............................. $\$ 1.50$ "speciosa. "B." Blossoms in July, when few trees are in bloom. The flowers are large, very showy and quite fragrant.

6 to 8 feet

Each $\$ 0.50$

8 to 10 feet

\section{Celtis - Nettle Tree}

Celtis occidentalis. "B." A native, known as the Hackberry. It is not unlike the Elm in appearance, with slender branches and rough bark. It does well in most soils, and its brownish-black berries hang on in profusion all Winter. It has value as an ornamental tree. "m."

Each $\$ 0.75$

\section{Cerasus - Cherry}

Cerasus Padus (European Bird Cherry). "B." Covered in May with long spikes of white flowers, followed by black berries. Can be grown as a shrub. A pretty ornamental tree, and useful to attract birds. "r."

3 feet ................................. $\$ 0.35$

" Japonica rosea. "C." An upright form of the double Rose-flowering Cherry. The flowers are large and double tinted with exquisite shades of rose and pink, freely produced in May. "m."

4 to 5 feet

Each $\$ 1.00$

" var. rosea pendula (Japan Weeping Rose-flowered Cherry). "C." " One of the most interesting and beautiful of weeping trees. It is smothered with its rose-tinted blooms, and always has a graceful and symmetrical habit, besides being favored with handsome foliage, which gives it merit when out of bloom. Especially useful for lawn planting. "m." Each
Cerasus Pennsylvanica (Wild Red Cherry). "B." Low, bushy tree, with red bark and fruit. Profuse in flowering. "r."

3 feet $\ldots \ldots \ldots \ldots \ldots \ldots \ldots \ldots$. Each $\$ 0.35$

“ ranunculiflora (Ranunculus-like Flowering Cherry). "C." An upright grower, producing large, double white flowers, resembling those of a Ranunculus. "m." of a Ranunculus. "m."

Each $\$ 1.25$

“ serotina (Native Black Cherry). "B." Covered in May with long spikes of white flowers, followed by black Cherries. A pretty, orna-

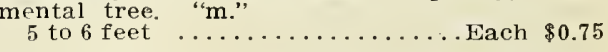

Cercidiphyllum - Kadsura Tree

Cercidiphyllum Japonicum. "B." A tree of compact, pyramidal outline. The heart-shaped leaves are rosy-purple in spring, silvery beneath. Prefers damp soil. "r."

4 to 5 feet ................. Each $\$ 1.00$

\section{Cercis - Judas Tree, or Red Bud}

Cercis Canadensis (American Judas Tree). "B." Before the foliage appears, the stems are covered with a profusion of reddish-purple flowers, quite unique in color and appearance. The leaves are heart-shaped with a glossy surface. "m" "heart-shaped with a glossy sur3 to 4 feet

4 to 5 feet $\ldots \ldots \ldots \ldots \ldots \ldots \ldots \ldots \ldots \ldots \ldots \ldots \ldots \ldots \ldots$ sach $\$ 0.50$

\section{Chionanthus - White Fringe}

(See Shrubs).

\section{Cladrastis - Yellow Wood}

Cladrastis tinctoria; syn. Virgilia lutea. "B." The bark resembles that of the American Beech, the growth being clean and smooth. Foliage light green, flowers white and peashaped, produced in long, pendulous racemes in June, covering the tree. A very hardy and beautiful variety. "m."

5 to 6 feet ............... Each $\$ 1.50$

\section{Cornus - Flowering Dogwood}

Cornus florida (White-flowering Dogwood). "C." American variety of irregular habit with spreading, open top, growing about 25 feet high. The flowers are white, produced in May, followed by scarlet berries and gorgeous $\mathrm{Au}$ tumnal coloring of the leaves. It associates well with other low trees. "s."

3 to 4 feet $\ldots \ldots \ldots \ldots \ldots \ldots \ldots \ldots \ldots$ Each $\$ 0.60$
4 to 5 feet $\ldots \ldots \ldots \ldots \ldots \ldots$ " 1.00

" var. rubra (Red-flowering Dogwood). "C." This merits all the favor which has been shown it by the public. The flowers are like Cornus florida, except that they are a deep rose color, freely produced. A flt companion to the white form. "s." Transplants best in early spring.

1 to 2 feet .............. Each $\$ 0.75$

2 to 3 feet $\ldots \ldots \ldots \ldots \ldots \ldots \ldots \ldots \ldots \ldots \ldots \ldots \ldots \ldots \ldots \ldots$ " 1.25

3 to 4 feet ................ 1.75

For late planting we offer plants in boxes or tubs at $\$ 2.00$ and $\$ 3.00$ each.

\section{Crataegus - Thorn}

Crataegus Azarolus var. Carrieri. "C." The deep green, glossy foliage remains late. Flowers large and white, the fruit scarlet and the size of a Cherry. " $m$.'

2 to 3 feet $\ldots \ldots \ldots \ldots \ldots \ldots$ Each $\$ 0.50$ " coccinea (American White Thorn). "C." A variety with large foliage. White flowers in May, succeeded by large scarlet fruit. "m." 3 to 4 feet ................ Each $\$ 0.50$ 4 to 5 feet $\ldots \ldots \ldots \ldots \ldots \ldots \ldots \ldots \ldots \ldots$. .75 " cordata (Washington Thorn). "C." Covered with small, bright fruit in clusters. Good foliage and habit.

2 to 3 feet .................... $\$ 0.50$

"Crus-galli (Cockspur Thorn). Long thorns, glossy foliage, and bright fruit in Autumn. Makes a fine hedge and screen plant. "m."

3 to 4 feet ................. Each $\$ 0.50$

4 to 5 feet $\ldots \ldots \ldots \ldots \ldots \ldots \ldots \ldots \ldots$. $\quad .60$ 
CRATAEgus-Continued.

Crataegus Oxyacantha (Common Hawthtorn). "C." The English Hedge Thorn, and excellent for this purpose in this country. Pure white flowers. "m."

3 to 4 feet

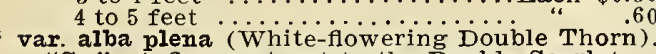

Each $\$ 0.50$ "C. " A fine contrast to the Double Scarlet or Paul's Thorn. "m."

4 to 5 feet.

" var. coccinea fl. pl. Pauli (Paul's Double Scarlet Thorn). "C." The best of the double varieties. The flowers are of brilliant carmine. "m."

4 to 5 feet ' var puniceo (Red, or Superb English Hawthorn). "C." Flowers large, dark red, and very showy. "m."

4 to 5 feet ................. Each $\$ 0.75$

\section{Cytisus}

(See Laburnum).

\section{Fagus - Beech}

All Beeches are very ornamental and beautiful. They are slow in growth and rather hard to establish after being moved. Transplant best early in the Spring.

Fagus ferruginea (American Beech). "A." Good in any situation, but preferring strong soil. "s." 3 to 4 feet s: sylvatica (European Beech). "A." Of slower growth than the American, with darker bark and more compact habit. Excellent for screen purposes. "s."

3 to 4 feet

Each $\$ 0.75$

"var. heterophylla (Fern-leaved Beech. "B." A tree of compact, elegant habit. Its foliage is finely cut and Fern-like, and its young branches are tendril-like in growth. "s." 2 to 3 feet ......................... $\$ 1.75$ "var. pendula (Weeping Beech). "B." A weeping tree of irregular shape, but a well-grown specimen will profoundly impress one "s"

4 to 5 feet .................. Each $\$ 2.50$ - var. purpurea pendula (Weeping Purple Beech). "B." In habit of growth like the preceding. Foliage bronze-purple in Spring, but fades toward Mid-summer. A rare and beautiful tree. "s."

4 to 5 feet ....................... $\$ 2.50$

" var. cuprea (Copper Beech). "A.", A fine tree, often confounded with River's Purple Beech. Its leaves have not the fine dark purple of the latter, and turn green much sooner. "s."

4 to 5 feet .............

“ var purpurea Riversii (River's Purple Beech). "A." Its leaves in good specimens are almost black, and hold their color throughout the season.

4 to 5 feet .................... $\$ 1.50$

5 to 6 feet

2.00

\section{Fraxinus - Ash}

The Ash is of rapid growth, and a clean, healthy vigorous tree. Moths will not feed upon its leaves.

Frazinus Americana (American White Ash). "A." A well-known native tree. Good in parks, grounds or streets. "m."

6 to 8 feet ..............Each $\$ 0.50$ 8 to 10 feet ............. 1.00

"excelsior aurea (Golden-barked Ash). "B." A distinct tree at all times, but especially in Winter, on account of its yellow bark and twisted branches.

to 8 feet

" var. pendula (Weeping Ash)" "B.;") known sort; onc of the finest lawn and arbor trees. "m"

6 to 8 feet

Each $\$ 1.75$

\section{Ginkgo - Maidenhair Tree, or Salisburia}

Ginkgo biloba. "B." A small tree from Japan. Grows into columnar form to about 40 feet. The foliage is formed like the Adiantum Fern. thick and glossy. Very desirable on smali grounds. "s."

6 to 8 feet

\section{Gleditschia - Honey Locust}

Gleditschia triacanthos (Honey Locust). "B." A fast-growing tree, with strong thorns and fine foliage. It is quite hardy, and ought to be planted more generally. 3 to 4 feet

Each $\$ 0.50$

\section{Gymnocladus - Kentucky Coffee} Tree

Gymnocladus Canadensis (Kentucky Coffee Tree). "B." Forming a large, irregular, open specimen, with immense, pinnate leaves and few twigs. Foliage bluish-green. In June it bears large panicles of green flowers, followed by very long pods. Quite desirable. Does well in low, wet places. "s."

Each $\$ 0.75$

\section{Juglans - Walnut \\ (See Nut Trees).}

\section{Koelreutaria - Varnish Tree}

Koelreutaria paniculata "B" If only for its mass of orange-yellow flowers, which in July cover the tree, this should be grown. It is a small-growing tree from China, with large, pinnate leaves. An unusually good lawn tree. m."

3 to 4 feet

Each $\$ 0.75$

\section{Laburnum - Golden Chain}

Laburnum vulgare (Cytisis Laburnum). "A." A native of Europe, with smooth and shining foliage. The name Golden Chain alludes to the length of the drooping racemes of yellow flowers, which appear in June. " $m$."

5 to 6 feet ........................... $\$ 1.00$

" var. pendula (Weeping Laburnum). "C." This tree produces very long, gracefully falling branches, while the racemes of rich golden flowers appear from every bud. "s"

6 to 8 feet ............................ $\$ 2.00$

\section{Larix - Larch}

Larix Europaea (European Larch). "A." Compact in growth, with light green foliage and drooping habit. Valuable as a lawn tree. "r." 3 to 4 feet 3 to 4 feet 1.50

Teptolepis; syn. Kaempferi (Japanese Larch). The most vigorous grower of the family. Slender. yellowish, ash-colored branches, and light foliage. The handsomest of the Larches. 3 to 4 feet ................. Each $\$ 1.00$ 4 to 5 feet

2.00

\section{Liquidambar - Sweet Gum}

Liquidambar styraciflua (Sweet Gum). "B." Its Palm-shaped leaves, glossy and green in Summer, take on in the Fall the most intense shades of purple, orange and crimson. "s."
6 to 7 feet ..................Each $\$ 1.50$

\section{Liriodendron - Tulip Tree}

Iiriodendron Tulipifera (Tulip Tree, or Whitewood). "A." Among the largest of our namens. Leaves glossy and fiddle-shaped. The flowers resemble Tulips, and are large and greenish-yellow, blotched with orange, appearing in June.

6 to 8 feet

Each $\$ 1.00$

\section{The Magnolias (Native Sorts)}

Magnolia acuminata (Cucumber Tree). "A." A tree of large, pyramidal growth, with deep green leaves and yellowish-white, inconspicuous flowers in May. The showy carmine

fruits are in shape like a cucumber. "m."
6 to 7 feet ................. Each $\$ 1.00$

glauca (Sweet Bay). "C." Bushy and irregular in growth. Its white flowers appear in June. In sheltered spots. its glossy leaves are almost evergreen. "s."

2 to 3 feet

Each $\$ 1.50$ 


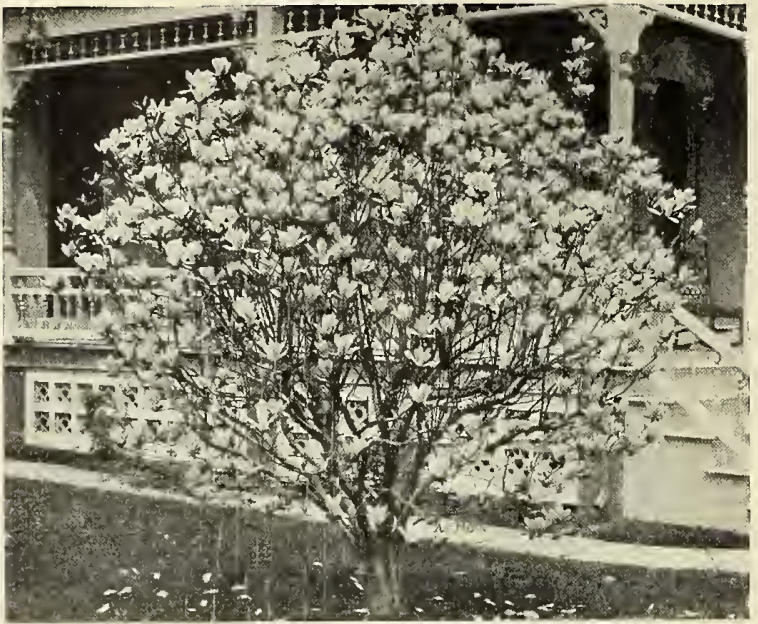

Magnolia Soulangeana.

\section{Japan and China Magnolias}

All are of dwarf habit and assume more readily the bush form. Should be planted in the Spring Magnolia Alexandrina. A choice variety, producing light pink flowers in the first week of May. "s."

3 to 4 feet

4 to 5 feet

Each $\$ 2.00$

2.50

" conspicua (Chinese White, or Yulan Magnolia).

"C." Makes a low, round tree, covered in

May with masses of large, snow-white, Lily-

like flowers. "s."

3 to 4 feet

Each $\$ 2.50$

Iennei (Lenne's Magnolia). "C." Its deep,

dark purple flowers are large and

opening in April.

3 to 4 feet
4 to 5 feet

Each $\$ 2.00$

soulangeana. "C.", Perhaps the most popular of all the Magnolias, being of vigorous growth, and blooming profusely, even when cuite small The flowers are large, pink on quite small. of petals and white inside.

3 to 4 feet ..................................... $\$ 2.00$ 4 to 5 feet

"speciosa. "C." Resembles the preceding sort a great deal. It is rather late in opening its flowers in Spring.

3 to 4 feet

4 to 5 feet

Each $\$ 2.00$

stellata (Hall's Magnolia). "C." A charming dwarf tree. Flowers double, pure white, or with a rosy flush: petals long and narrow. The blossoms greatly resemble our Pond Lily in appearance. The fragrance is delicate. all the Magnolias. "s."

$11 \%$ to 2 feet

Each $\$ 2.50$

\section{Morus - Mulberry}

Morus alba pendula (Teas' Weeping Mulberry). A small tree, with drooping branches and dense, deep green foilage. Generally grafted on stems 6 to 8 feet high. A beautiful and hardy

"var. Tatarica (The Russian Mulberry). Very hardy, with reddish fruit. "r." 5 to 6 feet .................................... $\$ 0.75$

" var. New American. "B." Valued for its large black and juicy fruit. Very vigorous in growth. Large and handsome foliage.

Fach $\$ 1.00$

\section{Nyssa - Sour Gum, Tupelo}

Nyssa sylvatica. "B." A native tree, too little known as it is one of our most ornamental. Its foliage, a shining green, turns in Autumn to a flaming scarlet. Prefers a damp situation and must be planted when small and pruned severely.

2 to 3 feet

Each $\$ 1.25$

\section{Ostrya - Ironwood}

Ostrya Virginica. "C." Resembling the Hornbeam. "s."

3 to 4 feet............Each $\$ 0.75$

Pavia - Buckeye

Pavia flava (Yellow Buckeye). "B." Pale green, downy leaves and yellowish-white flowers in May. "s."

5 to 6 feet....................... $\$ 150$

"Iyonil. "C." A round-headed tree, with showy, upright panicles of pale yellow flowers in May. "s."

5 to 6 feet............. Each $\$ 1.50$

" parviflora macrostachya (Dwarf Buckeye). "D.m." Low, spreading tree, with very attractive divided leaves, and bearing beautiful white flowers in upright panicles in June. Distinct and unusual.

$11 / 2$ to 2 feet........... Each $\$ 0.75$

\section{Persica - Peach}

Persica vulgaris flore alba plena (Double White-flowering Peach). "C." Covered in May with showy, white, double flow3 to 4 feet

"var $\ldots \ldots \ldots \ldots . . .$. Each $\$ 0.50$ "Cose-flowering Peach). "C." Flowers double, pale rose-colored, like small Roses. May.

3 to 4 feet............ Each $\$ 0.50$

var. folils purpureis (Blood-leaved Peach). "C.' Foliage a blood-red color in Spring, fading to deep green. The young growth preserves its dark color the "entire Summer. A very ornamental tree. "r."

3 to 4 feet .............................. $\$ 0.75$

\section{Phellodendron - Cork Tree}

Phellodendron Amurense (Chinese Cork Tree). "B." In growth much like the Ailanthus Flowers greenish white, followed by dark brown or black berries in Autumn. "r."

Each .................. \$1.50

\section{Platanus - Plane Tree}

Platanus orientalis (Oriental Plane). "A." A rapid grower and not affected by the air of cities, nor by insects. Its foliage is handsome and its growth is upright and clean.

8 to 10 feet ........................... $\$ 1.50$

" occidentalis (American Plane, Sycamore, or Buttonwood). "A." Leaves heart-shaped. In growth much like the preceding.

8 to 10 feet ............................... $\$ 1.50$

\section{Populus - Poplar}

The Poplars are all very hardy and fast growing, and therefore well adapted for screens or street planting. Special quotations will be given for Poplars in quantity.

Populus alba (White, or Silver Poplar). "B." Rapid and irregular in growth, with spreading habit. Leaves white underneath; upper surface green.

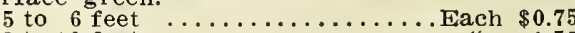

8 to 10 feet $\ldots \ldots \ldots \ldots \ldots \ldots \ldots \ldots \ldots$. 1.50

10 to 12 feet $\ldots \ldots \ldots \ldots \ldots \ldots \ldots \ldots \ldots \ldots$ " 2.00

"var. Bolleana. "A." Its habit is like the Lombardy Poplar, and it is a long-lived tree. Its bark is bluish gray, with dark green, tremulous leaves; white beneath. "r."

6 to 8 feet $\ldots \ldots \ldots \ldots \ldots \ldots \ldots$ Each $\$ 0.75$

8 to 10 feet $\ldots \ldots \ldots \ldots \ldots \ldots \ldots \ldots \ldots$ " 1.00

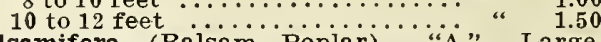

balsamifera (Balsam Poplar). "A." Large, glossy foliage, luxuriant growth. Holds its foliage well in Autumn.

6 to 8 feet ................................ $\$ 0.75$

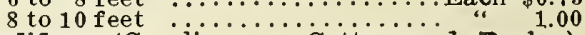
" monolifera (Carolina, or Cottonwood Poplar) "A." Good in almost any location, thriving at the seashore in poor, sandy soll. It form a fine-shaped, spreading tree, with large, dark. glossy leaves, and for screens is unequaled. "r "

8 to 10 feet $\ldots \ldots \ldots \ldots \ldots \ldots \ldots$ Each $\$ 0.50$ 10 to 12 feet ................ " 75

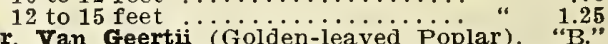

" var. Van Geertij (Golden-leaved Poplar). "B." A variety of the preceding, with aright, gold color contrast. "r."

4 to 5 feet $\ldots \ldots \ldots \ldots \ldots \ldots$ Each $\$ 0.50$

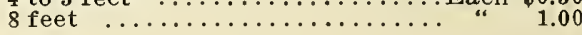




\section{POPULUS-Continued.}

Populus, nigra fastigiata (Lombardy Poplar). "B." A well-known tree of narrow, upright growth, with light green, small leaves. $41 / 2$ to 6 feet...Per $100, \$ 40.00$.. Each $\$ 0.50$

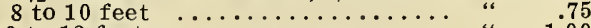

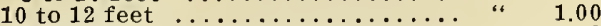

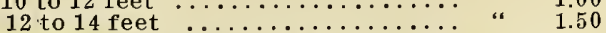
"tremuloides (American Aspen) "B." A popu-

6 to 8 feet ............................... $\$ 0.50$

8 to 10 feet $\ldots \ldots \ldots \ldots \ldots \ldots \ldots \ldots \ldots$ " 1.00

"tremuloides pendula. A rare and beautiful form of the above, with spreading and pendulous branches. A characteristic feature of this tree is the profusion of its very long catkins that appear in earliest Spring. Makes an excellent lawn tree.

8-foot specimens ...........Each $\$ 1.50$

\section{Prunus - Plum and Cherry}

Prunus Padus (Bird Cherry). "C." A handsome tree, with clusters of fragrant white flowers in May. The black, Currant-like fruit is much sought by the birds. "r."

3 to 4 feet ................................. $\$ 0.50$

" Pissardi (Purple-leaved Plum). "C." Handsome form, with purple leaves and wine-red fruits; one of the best of the small, purpleleaved trees, retaining its color until Fa.ll. "r."

4 to 5 feet ........................... $\$ 0.50$

\section{Prunus Triloba}

(See Shrubs).

\section{Pyrus - Flowering Apple}

Pyrus angustifolia (Bechtel's Double-flowering Crab). The tree is of medium growth, and the fowers are of immense size, of a beautiful pink color, highly fragrant. They are very double and resemble pink Roses.

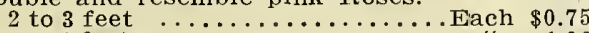

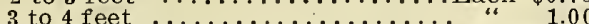

"bacata (Siberian Crab). "C," " Smail, spreading tree, with compact crown; smooth in all its parts; growth hardy and wiry; flowers double, delicate blush color.

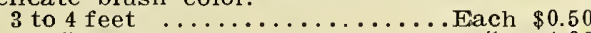
4 to 5 feet $\cdots \cdots \cdots$

"floribunda (Flowering C̈rab). "C.," 'Single flowers, burs carmine and white when open. Full of small red fruit in Autumn.

4 to 5 feet,$\cdots \ldots \ldots \ldots \ldots \ldots \ldots$ Each $\$ 1.00$

" Parkmani. "C." "From Japan. Each bud produces regularly five blossoms set on stems 3 inches long, which are so slender that they bend with the weight of the buds and bloom in a very graceful fashion. The buds are in a very graceful fashion. The buds are semi-double; the tree when in bloom presents a most gorgeous appearance.

2 to 3 feet

"Schiedeckeri. "C.," A beautiful variety of recent introduction. F'lowers double and bright rose color.

3 to 4 feet $\ldots \ldots \ldots \ldots \ldots \ldots \ldots$ Each $\$ 1.00$

" Toringo (Dwarf Crab). "C.," $\not$ A fine yellowfruited variety, with showy flowers; one of the best.

3 to 4 feet .......................... $\$ 0.75$

\section{Pyrus Sorbus - Mountain Ash}

Pyrus Sorbus Americana (American Mountain Ash). "B." A pretty small-sized tree, with abundant clusters oflarge orange berries in Autumn. . It fruits when young and is most desirable. "ns."

4 to 5 feet .............................. $\$ 0.75$

"Aucuparia (European Mountain "Ash). "B." Not as large in growth as the American form Covered through the Winter with large clusters of bright scarlet berries. "m."

4 to $41 / 2$ feet $\ldots \ldots \ldots \ldots \ldots \ldots \ldots \ldots$. Each $\$ 0.50$ 6 to 7 feet $\ldots \ldots \ldots \ldots \ldots \ldots \ldots$. $\$ \ldots . . \ldots$

var. pendula. "C.," One of the most pronounced weeping trees, its branches spreading and bending to the ground. Makes a fine individual specimen.

Each ..................\$1.50

"quercifolia (Oak-leaved Mountain Ash)" "B." Of fine pyramidal habit. Deeply lobed, oaklike leaves, green above and woolly underneath. "m".

6 to 8 feet

Each $\$ 1.00$

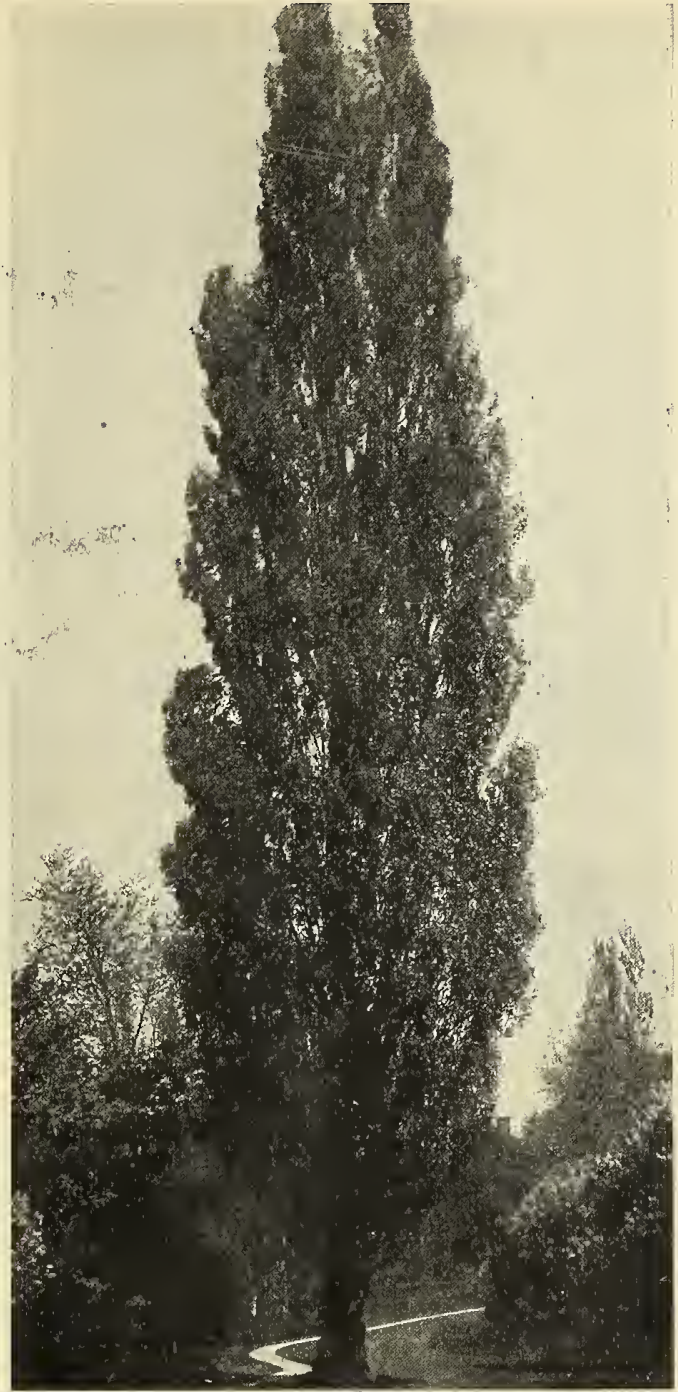

Populus nigra fastigiata-Lombardy Poplar.

\section{Ptelea - Hop Tree}

Ptelea trifoliata. A small, spreading tree, attaining a height of 8 to 10 feet. It has a handsome, glossy green foliage, and is used extensively for massing with coarse shrubbery. Very attractive in late summer when large very attractive in late Summer when large withstands extreme droughrs well, and is most useful for seashore planting, or for dry and sandy situations. "r."

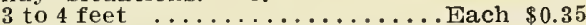
4 to 5 feet $\ldots \ldots \ldots \ldots \ldots \ldots \ldots \ldots \ldots \ldots \ldots$. $\$ \ldots \ldots \ldots$. $\$ 0.35$

“ var, aurea (Golden Hop Tree). Resembles the preceding, but has bright golden foliage, which retains its color until frost.

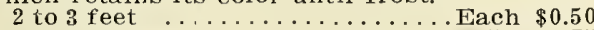

3 to $4 \frac{1 / 2}{2}$ feet $\ldots \ldots \ldots \ldots \ldots \ldots \ldots \ldots$ * $\quad .75$

Special Quotations will be given on any Shade Trees in quantity. MIso on extra large specimens not mentioned in this catalogue. 


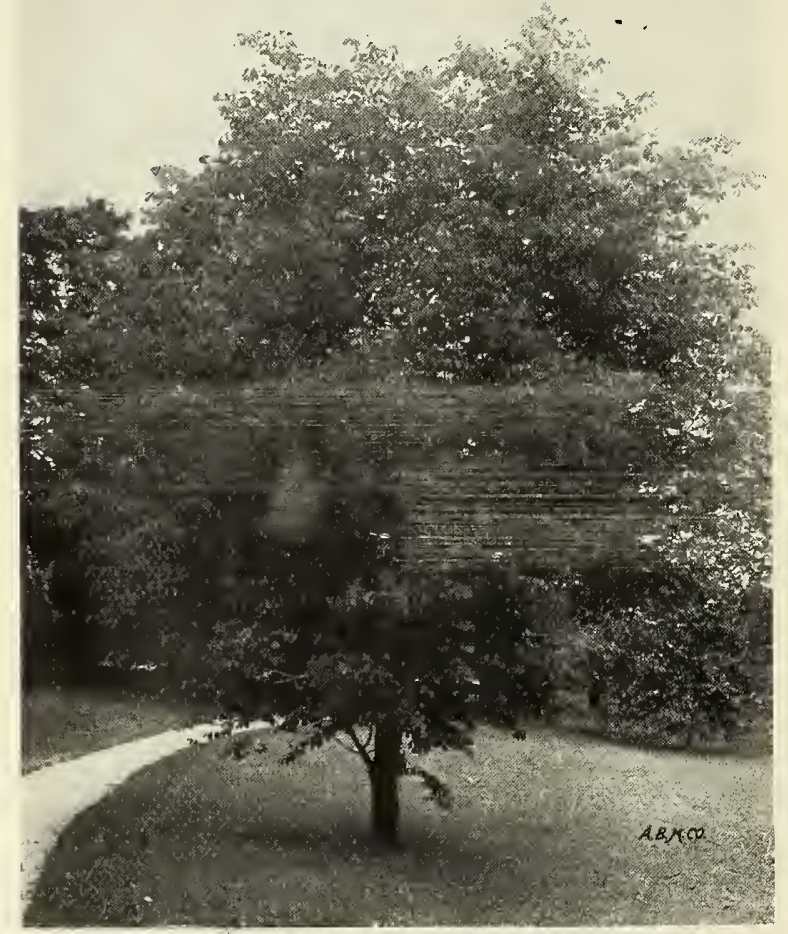

Ptelea trifoliata-Hop Tree (See page 21).

\section{Quercus - Oak}

Quercus alba (White Oak). "A." A broad-spreading, massive tree, one of the finest natives of America. Foliage purple in Autumn. A good street tree. "s."

4 to $41 / 2$ feet $\ldots \ldots \ldots \ldots \ldots \ldots$ Each $\$ 0.75$

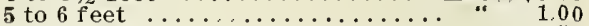

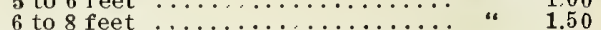

" bicolor (Swamp White Oak). "A." One of the best for ornamental planting. Makes an immensely wide tree, having large, dack green leaves and large acorns. "s."

4 to $41 / 2$ feet $\ldots \ldots \ldots \ldots \ldots \ldots$ Each $\$ 0.75$ 5 to 6 feet ............... " 1.00

" coccinea (Scarlet Oak). "B." It forms a large tree of fine proportions, the leathery leaves turning to a fiery scarlet in Autumn. A good street iree.

5 to 6 feet .................................. $\$ 1.00$ 6 to 8 feet ................... 1.50

" macrocarpa (Mossy-cup Oak). "B." Of massive, wide growth, with large, heavy leaves and beautiful mossy acorns. Bark corky and ridged. "M."

4 to $4 \frac{1}{2}$ feet $\ldots \ldots \ldots \ldots \ldots$ Each $\$ 0.75$

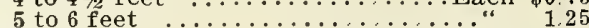

" rubra (Red Oak). "A." An American variety, rapid in growth, with large foliage, which assumes in the Fall a purplish-scarlet hue. It makes a fine specimen and cannot be too highly recommended for general planting.

6 to 8 feet $\ldots \ldots \ldots \ldots \ldots$ Each $\$ 1.00$

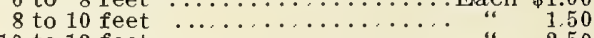
10 to 12 feet $\ldots \ldots \ldots \ldots \ldots \ldots \ldots \ldots \ldots$ " 2.50

" palustris (Pin Oak). "A." It is distinguished by its elegant growth and the drooping tendency of its limbs, and by its fine, deeply cut foliage, which, in the Fall, colors brilliantly. Being one of the easiest Oaks to transplant, it is in great favor as a street tree. " $r$."

5 to 6 feet $\ldots \ldots \ldots \ldots \ldots \ldots \ldots$ Each $\$ 0.75$

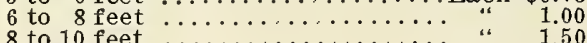

\section{Robinia - Locust or Acacia}

Robinia Pseudacacia (Black Locust). "B." Tree of large size, rapid growth and valuable for timber as well as quite ornamental. The flowers are disposed in long, pendulous racemes, white or yellowish, very fragrant, and appear in June.

5 to 6 feet ..............Each $\$ 0.50$

\section{Salisburia}

\section{(See Ginkgo).}

\section{Salix - Willow}

Salix alba (Common White Willow). "A." Well adapted to wet ground, where it grows into a large, broad tree. " $r$."

5 to 6 feet $\ldots \ldots \ldots \ldots \ldots \ldots$ Each $\$ 0.50$

"vitellina aurea (Golden-barked Willow). "B." A very showy variety, with golden bark of high color, very conspicuous in Winter. "r."

4 to 5 feet ........... Each $\$ 0.35$

5 to 6 feet $\ldots \ldots \ldots \ldots \ldots \ldots$ " .50

6 to 8 feet $\ldots \ldots \ldots \ldots \ldots \ldots \ldots$.. $\quad .75$

8 to 10 feet ............ 1.00

"var. Britzensis (Salmon-barked Willow). An equally showy sort, with vivid yellowish-red bark. Grows in any soil.

2 to 3 feet ..................... $\$ 0.35$

"Wiscongin Weeping. A variety resembling the Babylonian Willow, except that it is more hardy.

5 to 6 feet ................... $\$ 0.50$

"Caprea var. pendula (Kilmarnock Weeping Willow). "C." A good weeping tree for small lawns.

2-year head .............Each \$1.50

" pentandra, or laurifolia (Laurel-leaved Willow). "B," Leaves dark, glossy green, highly ornamental. Excellent for seashore planting.

3 to 4 feet $\ldots \ldots \ldots \ldots \ldots$ Each $\$ 0.35$

4 to 5 feet $\ldots \ldots \ldots \ldots \ldots \ldots \ldots \ldots \ldots \ldots$ " $\$ 50$

6 to 8 feet $\ldots \ldots \ldots \ldots \ldots \ldots \ldots \ldots \ldots \ldots \ldots \ldots \ldots \ldots$

Special quotations for these in quantity. " regalis (Royal Willow). "C." Foliage silvery. Good for color contrasts.

3 to 4 feet ................. Each $\$ 0.50$ " rosmarinifolia (Rosemary Willow). "C." Long narrow, silky foliage, white underneath Grafted plants make a fine, globular head. Quite ornamental

Standards, 2-year heads........ Each $\$ 2.00$

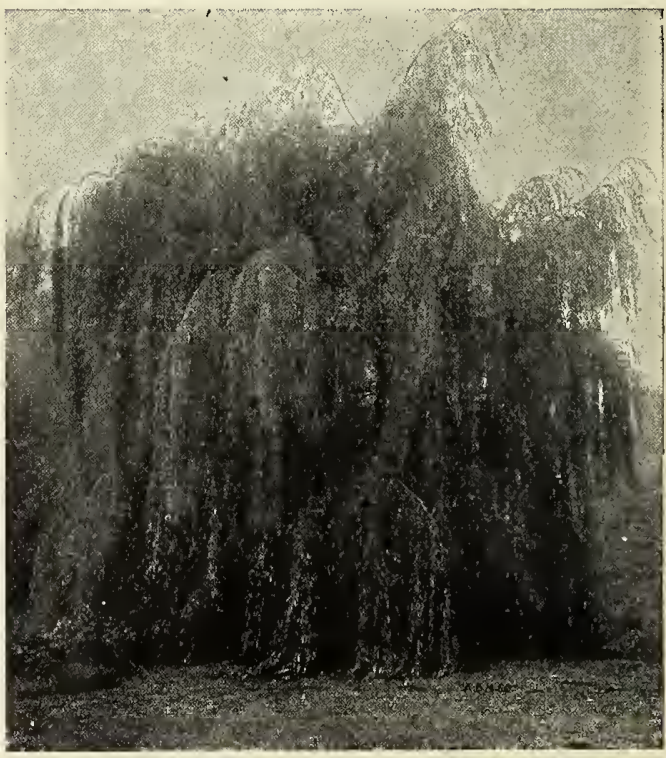

Salix-Wiseonsin Weeping Willow. 


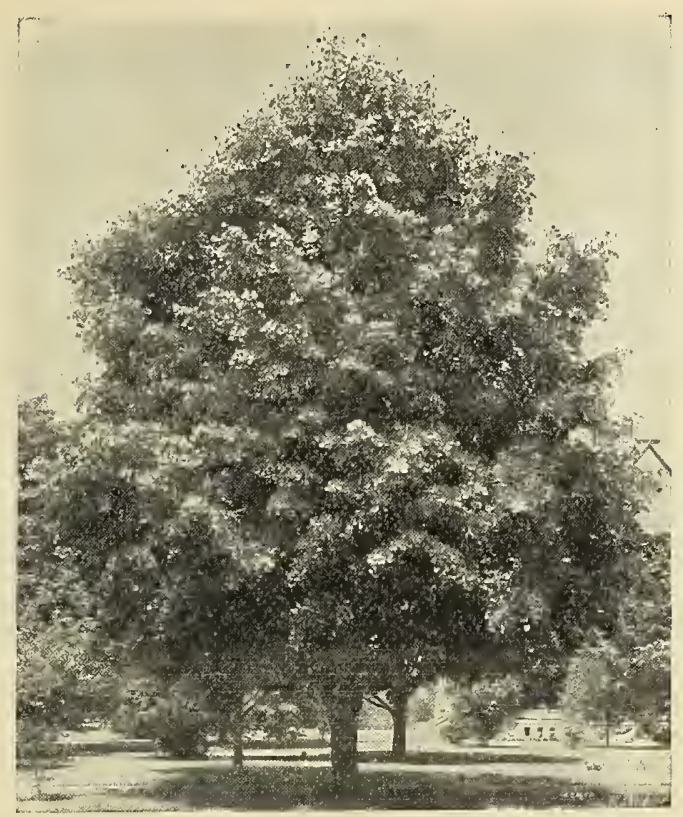

Tilia Americana-American Linden.

\section{Sassafras}

Sassafras officinale. "B." Has peculiar, large, deep green foliage, which turns to a deep yellow in the Fall. The flowers, small and yellow, appear in little bunches in May, and are very fragrant. Well known for its aromatic bark and roots. "s."

3 to 4 feet . .................. Each $\$ 1.00$

\section{Syringa - Lilac}

Syringa Japonica (Japanese Tree Lilac). "B." A pyramidal tree with upright branches and pale green leaves. Its panicles of white flowers are often more than a foot long. It is rapid in growth, very hardy and useful in shelter belts, as well as for its ornamental character. The first trees of this variety ever commercially grown were propagated in our nurseries in 1885 , and since they have been distributed to all parts of the world. "r."

3 to 4 feet ................... Each $\$ 0.50$

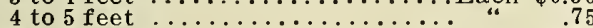

5 to 6 feet ............... " 1.00

\section{Taxodium - Deciduous or Bald} Cypress

Taxodium distichum. "B." The fine, feathery foliage of this tree, its rapid pyramidal growth and beauty when in full foliage, find for it a place in every collection. Though preferring a damp situation, it does not demand it, as many fine specimens are thriving in dry soil in high altitudes.

3 to 4 feet ............... Each $\$ 0.50$ 4 to 5 feet

\section{Tilia - Linden or Lime}

The Lindens are excellent shade trees, spreading in growth and forming large spcimens. They do well on ordinary soils, making comparatively rapid growth.

Tilia Americana (Linden or Basswood). "A." The largest growing Linden, making a majestic tree. Suitable for parks or streets. When in blossom its yellow flowers are intensely fragrant. A fine and valuable tree, "r."

8 to 10 feet .................. Each $\$ 1.00$ 10 to 12 feet $\ldots \ldots \ldots \ldots \ldots \ldots \ldots \ldots \ldots$ " 1.50

"dasystyla (Crimean Linden). A vigorous tree, bright golden bark, leaves darker and of a softer green than those of the common European Linden. Yellow twigs, striking in Winter. "r."

8 to 10 feet $\ldots \ldots \ldots \ldots \ldots \ldots \ldots$ Each $\$ 1.00$ 10 to 12 feet $\ldots \ldots \ldots \ldots \ldots \ldots \ldots \ldots \ldots$ " 1.50
"Europaea (Lime, or European Linden). "B." Has darker bark and smaller foliage than the preceding.

6 to 8 feet .................... $\$ 0.75$ 8 to 10 feet $\ldots \ldots \ldots \ldots \ldots \ldots \ldots \ldots \ldots \ldots \ldots \ldots \ldots$ " 1.00 10 to 12 feet ................. " 2.00

“ var. laciniata (Fern-leaved Linden). "B." Red bark and twigs, and deeply cut foliage. Perfectly hardy and makes a splendid lawn tree. "s."

6 to 8 feet ........................ $\$ 1.50$

"tomentosum; syn. argentea (White, or Silver Linden). "B." Light green foliage, silvery beneath. 6 to 8 feet ................. Each $\$ 1.00$ 8 to 10 feet .............." 1.50

\section{Ulmus - Elm}

Ulmus Americana (American White Elm). "A.' Lofty and spreading, with drooping branches. "m."

6 to 8 feet ...................... $\$ 0.50$ 8 to 10 feet $\ldots \ldots \ldots \ldots \ldots \ldots \ldots$. 1.00 10 to 12 feet $\ldots \ldots \ldots \ldots \ldots \ldots \ldots \ldots \ldots$ " 1.50 Extra large speimens............ $\$ 3.00$ to 5.00

" campestris (English Elm). "B.", More erect in growth, compact, and with smaller foliage and twiggy branches and trunk. A hardy, valuable tree. "s."

6 to 8 feet .............. Each $\$ 1.00$ 8 to 10 feet $\ldots \ldots \ldots \ldots \ldots \ldots \ldots \ldots$ Each $\$ 1.00$

"fulva (Red, or Slippery Eim). "B." Larger leaves than the American, and straggling, open head. "r."

"Camperdowni pendiuia.................... $\$ 1.00$ (Camperdown Weeping "Tlm) "C" " (Camperdown Weeping Elm). "C." A remarkable, picturesque weeping tree which extends its branches horizontally until it forms a complete arbor, its outer branches touching the ground. It does not grow over 15 feet high, while the spread of its branching head will cover 30 feet or more.

Strong heads ............... Each $\$ 2.00$ " var. Funtingdoni (Hütingdon Eim). "B." "One of the finest and most rapid growing Elms known. Broad foliage.

8 to 10 feet

\section{Virgilia}

(See Cledrastis).

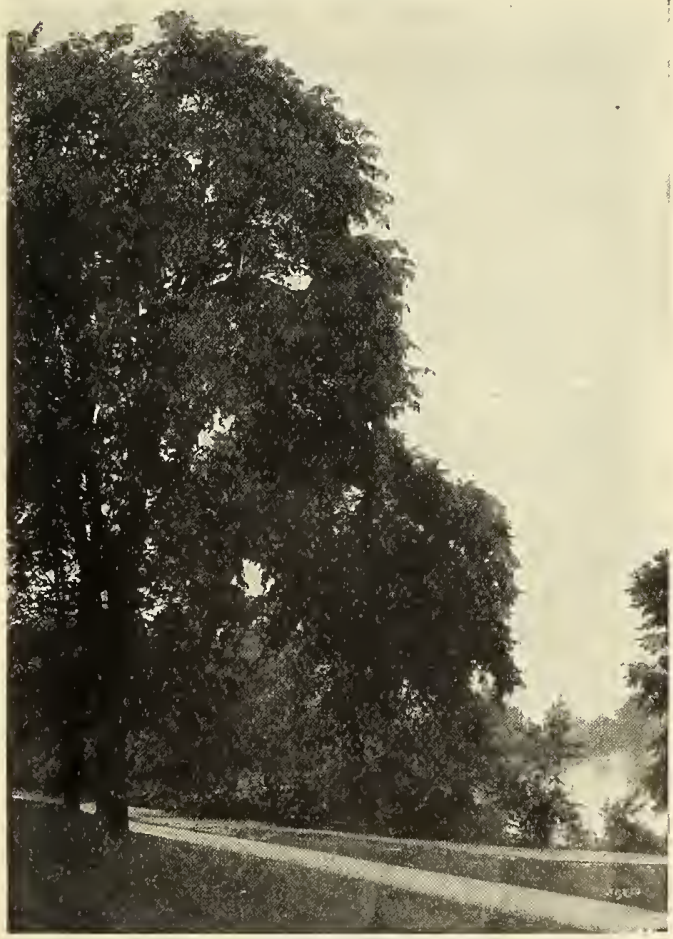

Ulmus Americana-American EIm. 


\section{Ornamental Deciduous Shrubs}

The following list contains every variety of hardy flowering shrubs worthy of cultivation in our climate.

The sizes of shrubs named below are those usually preferred by planters. If desired, we can generally supply larger or small sizes, and will quote prices on application.

Abbreviations denoting ultimate height: "L," large; "M." medium; "D." dwarf.

\section{Althaea}

(See Hibiscus).

\section{Amelanchier - Shadbush}

Amelanchier botryapium (Dwarf' Juneberry). "L."

Bush or small tree; showy white flowers in

April; fruit juicy, of good flavor.

$21 / 2$ to 3 feet ........ Each $\$ 0.35$, doz. $\$ 3.50$

\section{Amorpha - Bastard Indigo}

Amorpha canescens (Lead Plant). "S." June. Deep blue, attractive flowers. Foliage ashDach $\$ 0.35$, doz $\$ 3.50$

"fruticosa (False Indigo). "L." June. Long, pendulous branches. Indigo-colored flowers in finger-like spikes. Valuable for massing. Good on poor soil.

3 to 4 feet $\ldots . . \ldots . .$. Each $\$ 0.35$, doz. $\$ 3.50$

\section{Aralia - Angelica Tree}

Aralia pentaphylla (Five-leaved Aralia). "M." A oraceful shrub, with arching, spiny branches and bright green, shining foliage. Excellent on rocky banks and slopes, and also valuable

for hedges. 3 feet ............ Each $\$ 0.40$, doz. $\$ 4.00$ "spinosa. (See Deciduous Trees)

\section{Aronia}

(See Pyrus arbutifolia).

\section{Azaleas}

These are, without exception, the most showy of flowering shrubs, dwarf in habit, and associate well with other shrubs or can be grouped in masses. They prefer deep leaf-mould soil or peat.

\section{NATIVE AZALEAS}

Azalea arborescens (Smooth Azalea). "M." July.

A large and spreading Azalea with handsome, dark green foliage, producing white and rosetinted blossoms late in Summer. Highly fragrant.

18 inches ...Each $\$ 0.75$

" calendulacea (Flame Azalea)." "M.," June In May and June this Azalea is a mass of blossoms of all shades, from light straw color to the deepest orange.

18 inches $\ldots \ldots \ldots$ Each $\$ 0.60$ 24 inches

nudiflora (Pinxter Flower) "“ï;" 'May The brightest colored of all our Northern native Azaleas. Very sweet scented.

18 inches

"Vaseyi, or Rhododendron Vaseji." "M." June. Its pink or purple blossoms, which are yery like the blossoms of the Rhododendrons, are very fine.

18 to 24 inches ...................... $\$ 1.00$

viscosa (White swamp Honeysuckle). "M." June and July. Flowers in elusters, pure white, with shades of pink, and intensely fragrant.

$$
2 \text { feet }
$$

Each $\$ 0.75$

EUROPEAN AZALEAS

Azalea Pontica (Ghent Azaleas). "D." Fragrant flowers ranging from white to deep crimson appear in great profusion in early Spring, literally covering twig and branch.

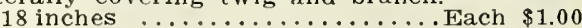

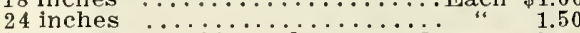

Mollis. Dwarf habit and larger flowers than the Ghent. All shades of red, white, yellow and orange; perfectly hardy, thriving in sunny positions anywhere.

Named varieties:

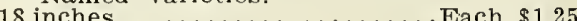

24 inches $\ldots \ldots \ldots \ldots \ldots \ldots \ldots \ldots \ldots \ldots$ " 1.50 Mixed varieties:

18 inches ......... Each $\$ 0.75$, doz. $\$ 7.50$ STANDARD AZALEAS

Azalea Mollis. In standard form, with bushy tops, well set with buds. All shades of color from almost white to dark red.

$21 / 2$ to 3 feet ......................... $\$ 2.50$

\section{Bayberry \\ (See Myrica).}

\section{Benzoin}

Benzoin odoriferum (Spice Bush). "L." A strong growing shrub, with bright green foliage flowers yellow, appearing before the leaves; has red, oblong, spicy berries; bark is aromatic.

2 to 3 feet .............. Each $\$ 0.35$

\section{Berberis - Barberry}

Berberis Thunbergii Thunberg's Japanese Barberry). "M." June. A species from Japan, with round, drooping habit; leaves of a fine, brilliant green in summer, taking on from early Autumn till December the most glowing colors. After the leaves fall the branches are seen to be loaded with scarlet-crimson berries. It is the very best of all plants to form "a hedge, being impenetrable and thickly set with spines, and never growing bare.

12 to 15 inches $\ldots \ldots$. Each $\$ 0.20,100 \$ 10.00$

15 to 18 inches ..... " .25 , " 15.00

18 to 24 inches ...... " $\quad .30$, " 20.00

"vulgaris (Common Barberry). "L." June. Vigorous habit; loose, open growth, with quantities of red berries in pendulous clusters in Autumn and Winter.

2 to $2 \frac{1}{2}$ feet .........Each $\$ 0.30$, doz. $\$ 3.00$

“ var. purpurea (Purple Barberry). “M." Deep purple foliage all summer. Valuable for massing and hedging.

2 to $2 \frac{1}{2}$ feet $\ldots \ldots \ldots$ Each $\$ 0.35$, doz. $\$ 3.50$

\section{Calycanthus - Sweet Shrub}

Calycanthus floridus (Carolina Allspice). "M." All Summer. Fine, glossy foliage and Pineapple scented, chocolate-colored flowers.

2 to 3 feet .........Each $\$ 0.35$, doz, $\$ 3.50$

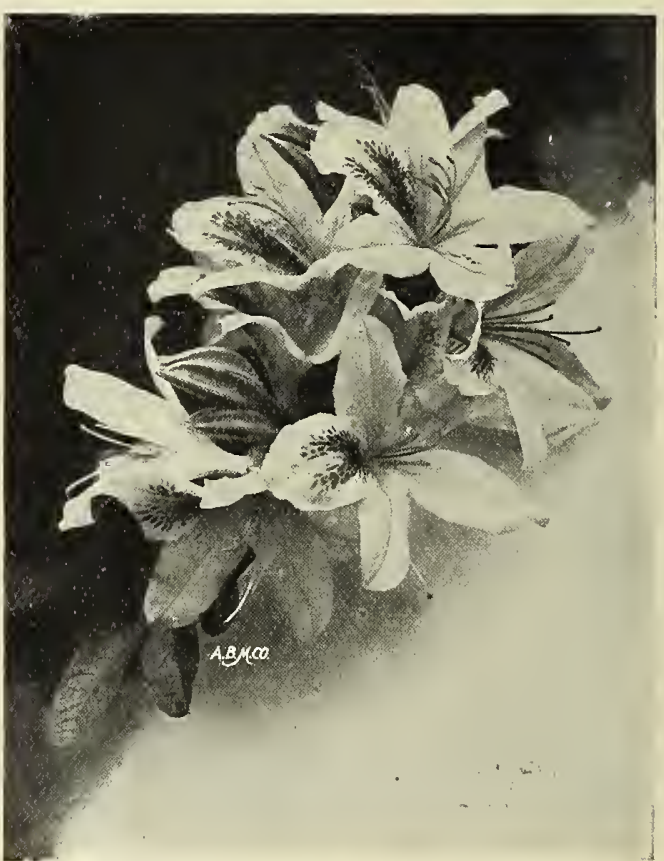

Azalea Mollis. 


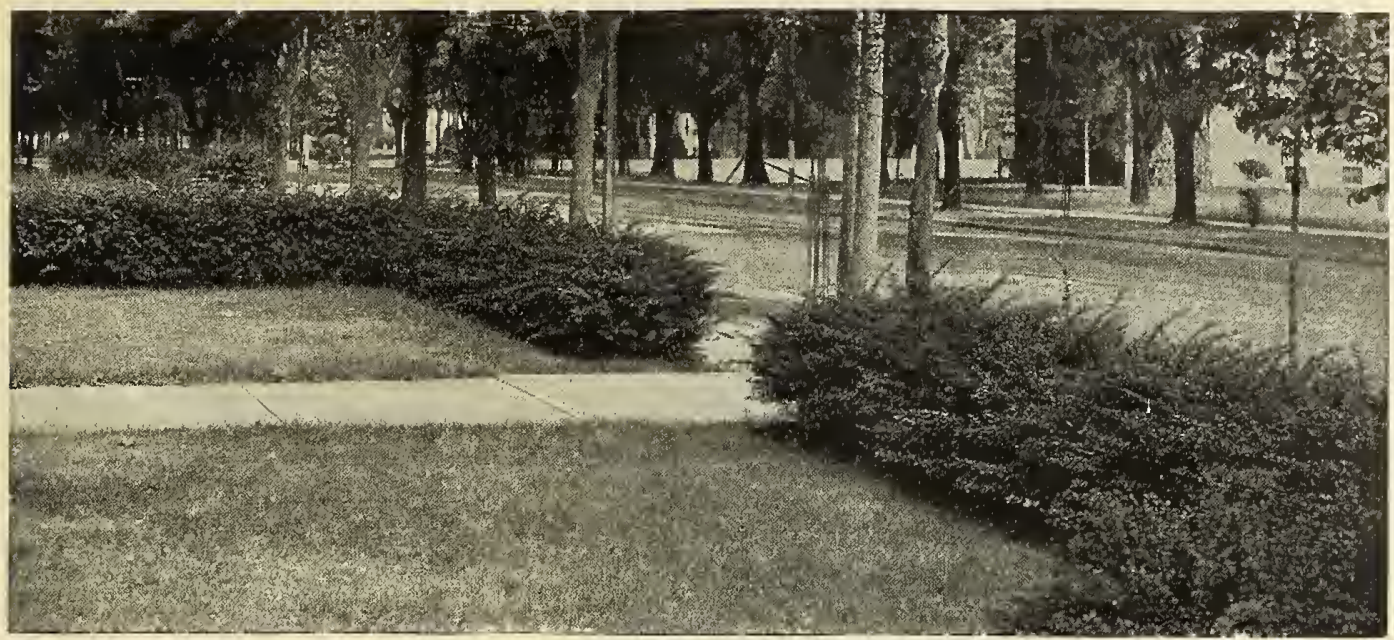

Hedge of Berberìs Thunbergii-Japanese Barberry.

\section{Caragana - Siberian Pea Tree}

Caragana arborescens. "L." June. Showy, small yellow flowers. Dark green wood and neat foliage
3 to 4 feet
Each $\$ 0.35$, doz. $\$ 3.50$

\section{Caryopteris - Blue Spiraea}

Caryopteris Mastacanthus. "D." Low-growing shrub, with flowers of rich lavender blue, in Autumn. In New England the tops are cut back by the Winter, and it is necessary to protect with some covering.

Each $\ldots \ldots \ldots \ldots \ldots \ldots \ldots \$ 0.25$, doz. $\$ 2.50$

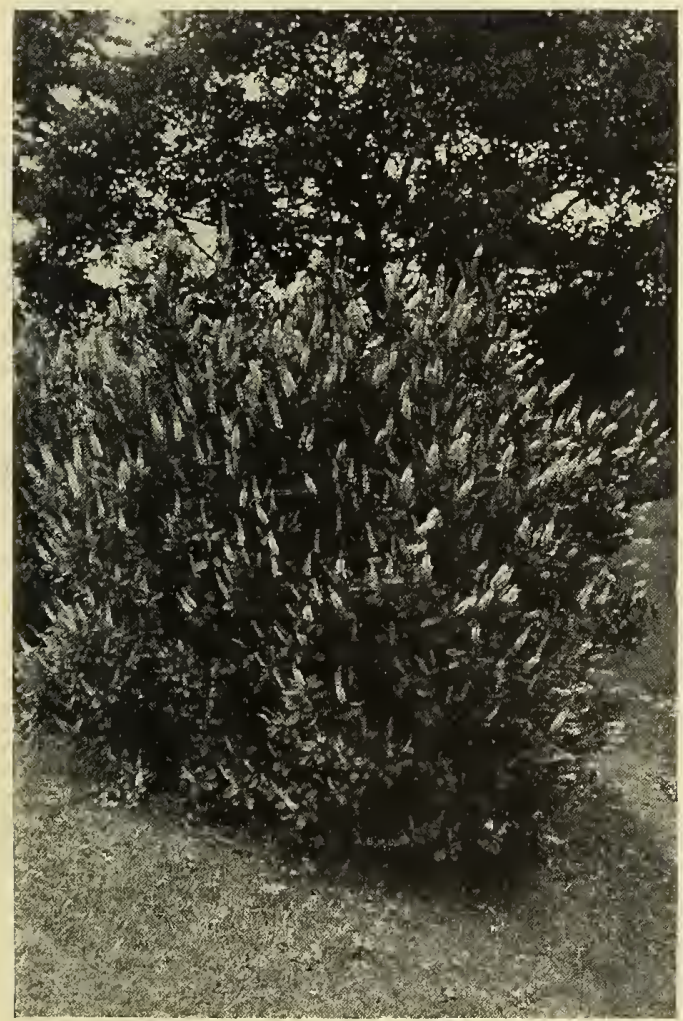

Clethra-Sweet Pepper Bush.
Ceanothus - New Jersey Tea

Ceanothus Americanus. "D." June. A shrub good on dry soils. Numerous small. white flowers in dense panicles, entirely covering the foliage. The tops Winter-kill unless protected.

Each $\ldots \ldots \ldots \ldots \ldots \ldots \ldots \$ 0.35$, doz. $\$ 3.50$

\section{Cephalanthus - Button Bush}

Cephalanthus occidentalis. "M." July. This shrub grows well in moist or wet ground, and its curious blossoms, on long stems, which hang all summer as brown seed-balls, are very picturesque.

Each .............\$0.35 doz. $\$ 3.50$

\section{Cercis}

(See Deciduous Trees).

\section{Chionanthus - White Fringe}

Chionanthus Virginica. "L." June. One of the most ornamental of shrubs, producing racemes of fringe-like white flowers. The leaves are moderately large and dark green. Will thrive in low, marshy ground as well as in higher situations.

2 to 3 feet ..........Each $\$ 0.50$, doz. $\$ 5.00$

\section{Clethra - White Alder}

Clethra alnifolia (Sweet Pepper Bush). "M." July to September. Spikes of highly fragrant white flowers are produced in lavish profusion during nearly the entire Summer. Excellent for growing in shady spots.

2 to 3 feet .......... Each $\$ 0.30$, doz. $\$ 3.00$

\section{Colutea - Bladder Senna}

Colutea arborescens. "L," July. Of compact growth. Light green, Acacia-like foliage, yellowish red, Pea-shaped flowers, followed by curious red, bladder-shaped pods. Hardy and good in any soil.

3 to 4 feet ........... Each $\$ 0.35$, doz. $\$ 3.00$

\section{Comptonia - Sweet Fern}

Comptonia asplenifolia. "D." A native with Fernshaped dark green foliage. Good on dry, poor soil.

18 to 24 inches ......Each $\$ 0.25$, doz. $\$ 2.50$

\section{Corylus - Filbert}

Corplus Avellana (English Filbert). "I." A large growing bush, with good foliage, and producgrowing bush, with good foliage, and prod

18 to 24 inchees ...... Each $\$ 0.35$, doz. $\$ 3.50$

"Avellana var. purpurea (Purple Hazel). "M." A fine, broad-leaved bush, with constant deep purple color.

18 to 24 inches .......Each $\$ 0.50$, doz. $\$ 5.00$ 


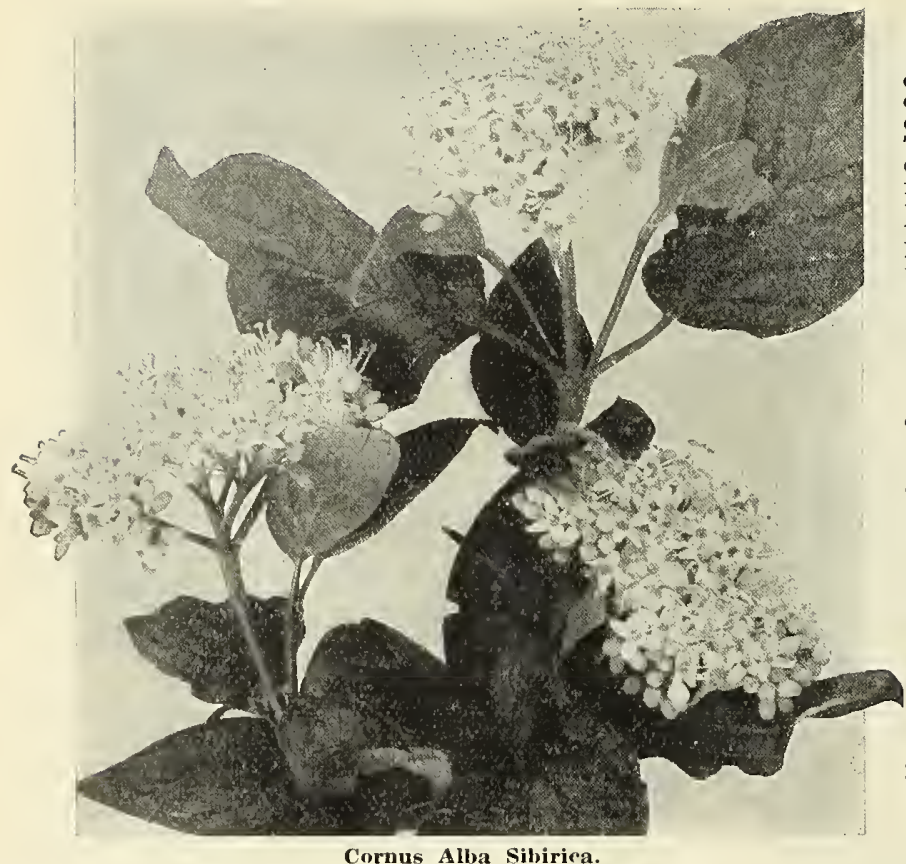

Cornus Alba Sibiriea.

Cornus alba sibirica. "M" In the Winter this

is the most showy of all the shrubs, standing out bright and cheerful with its brilliant red bark. It should be planted in groups where its color effect is visible at a distance. It has healthy, compact foliage, white flowers and white berries.

2 to 3 feet ..........Each $\$ 0.25$, doz. $\$ 2.50$

" var. elegantissima variegata. "M." A splendid, variegated form of the above, with silver and green foliage.

2 to 3 feet $\ldots \ldots \ldots$ Each $\$ 0.40$, doz. $\$ 4.00$

"alba Spaethi. "Mi," One of the finest of recently introduced shrubs. Variegated with pale yellow, and most distinct and valuable in all plantings.

2 to 3 feet ....... Each $\$ 0.40$, doz. $\$ 4.00$

“ alternifolia (Alternate-leaved Dogwood). "L."

A very distinct and graceful form; branches arranged in whorls giving tier-like effect: bunches of white flowers borne about the close of May, followed by deep blue berries.

3 to 4 feet

Each $\$ 0.35$

4 to 5 feet

" florida (See Deciduous Trees)

Mas, or mascula (Cornelian Cherry). "L." Handsome shrub of dense growth, with glossy foliage; very attractive in early spring, with its yellow flowers, and again in the Fall, with shining scarlet fruit.

3 to 4 feet ................. Each $\$ 0.50$

" paniculata (Panicles, or Gray Dogwood). "L." July and August. A bush with a multitude of finely branched stems, the whole plant taking the form of a round umbel of twigs.

2 to 3 feet ........... Each $\$ 0.35$, doz. $\$ 3.50$

" sanguinea. "L." "June." Most valuable for its blood-red bark in Winter. Low-branching habit and handsome leaves.

2 to 3 feet ......... Each $\$ 0.35$, doz. $\$ 3.50$

" sericea (Silky Cornei) "L" Purple-twigged. Grows very strong. Pale blue berries. Very effective in groups or masses and invaluable for seashore planting.

3 to 4 feet .......... Each $\$ 0.35$, doz. $\$ 3.50$

"stolonifera. "M."; Bark similar to that of the C. alba. Habit of growth spreading.

2 to 3 feet .......... Each $\$ 0.35$, doz. $\$ 3.50$

"stolonifera aurea (Golden-barked Dogwood) A striking contrast when planted with the red-barked variety.

18 inches ......... Each $\$ 0.35$, doz. $\$ 3.50$

2 to 3 feet $\ldots \ldots \ldots \ldots \ldots$ Each $\$ 0.40$, doz. $\$ 4.00$

. $\$ 0.50$, doz, $\$ 5.00$

Daphne var. alba. Pure white flowers; orange fruit. Each ..............\$0.50, doz. $\$ 5.00$

\section{Cydonia - Japan Quince}

There are several flowering varieties, differing only in their color. Although of straggling growth, they can be prunTheir desirable shapes without injury. early in the Spring in great profusion: foliage bright green and glossy all through the Summer. It is sufficiently thorny and strong to make a valuable hedge, and its beautiful flowers make it handsome for that purpose.

Cydonia Japonica (Fire Bush) "M" May. Glossy dark foliage, with reddish tints. Large, deep scarlet flowers in abundance, followed by large ruit.

2 reet.... Each $\$ 0.30$, doz. $\$ 3.00$ single, white Japan

$I$ to 2 feet

"var. Maulei. Beautiful orange flowers Rare.

" var to 2 feet "...,"...... Each $\$ 0.50$ of the most useful and handsome low shrubs, with dense foliage on recurving branches. In May it is completely covered with large, deep scariet flowers, followed by sweet-scented fruit.

to 2 feet .. Each $\$ 0.35$, doz. $\$ 3.50$

\section{Daphne - Mezereon}

Daphne Mezereum (Common Mezereon). "D." March. The earliest flowering of shrubs. The fragrant red flowers opening before the leaves appear,

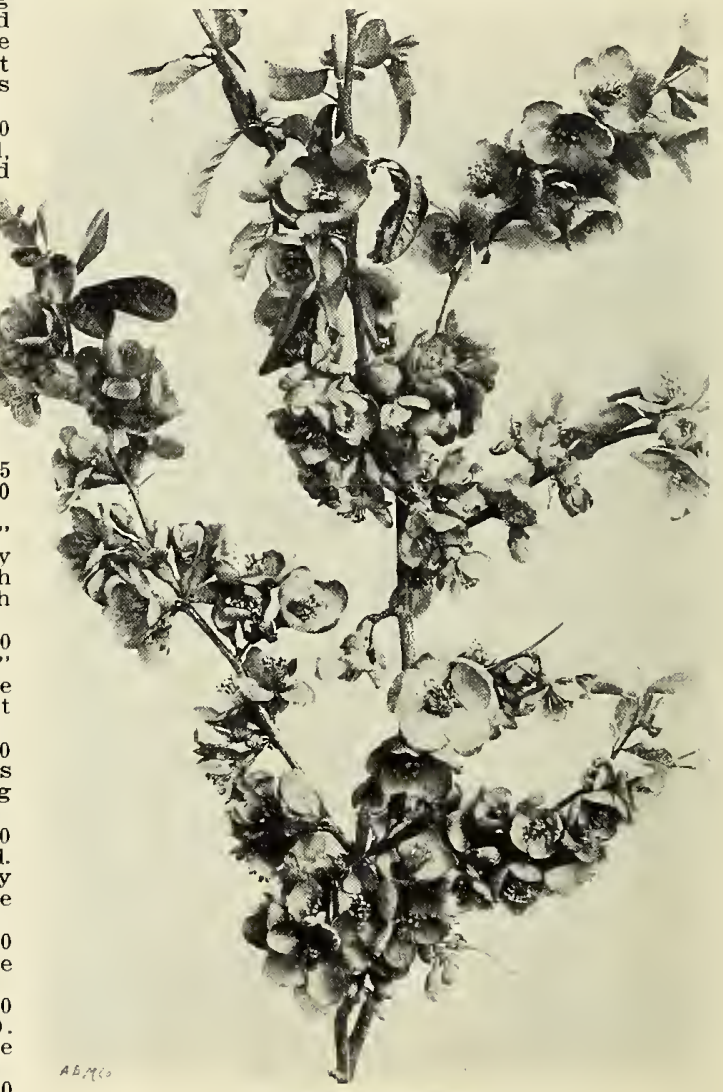

Cydonia Japonica. 


\section{Desmodium \\ (See Lespedeza).}

\section{Deutzia}

One of the most desirable shrubs to plant as individual specimens, or for grouping. Their hardiness, luxuriant foliage and profusion of attractive flowers render them deservedly among the most popular of flowering shrubs.

Deutzia crenata fl. pl. (Double Pink Deutzia). "L." June. Very double, white flowers tinged with purplish rose. 3 feet ................. Each $\$ 0.35$

" var. Pride of Rochester. "L." June. More vigorous and with larger panicles of flowers than the $D$. crenata flora plena. Blossoms are tinted with rose. 3 feet ......... Each $\$ 0.35$, doz. $\$ 3.50$

" gracilis (Slender Deutzia). "D." May or June. It forms a round, dense bush, and is covered with snow-white flowers. 15 to 18 inches . Each $\$ 0.30$, doz. $\$ 3.00$

" Iemoinei. "S." A remarkably fine hybrid. The branches are entirely covered with erect panicles of large, pink flowers. 2 feet ......... Each $\$ 0.35$, doz. $\$ 3.00$

\section{Diervilla - Weigela}

Diervilla candida (White Weigela). "L." Vigorous and fine habit; the long, tubular white flowers are produced from June all through the summer.

3 feet ............ Each $\$ 0.35$, d.oz. $\$ 3.50$

" floribunda. "M." June. Deep crimson flowers, very freely produced.

3 feet ............. Each $\$ 0.35$, doz. $\$ 3.50$

“ amabilis. "M." June. A pink-flowering variety and one of the best.

3 feet ............ Each $\$ 0.40$, doz. $\$ 4.00$

“ rosea. "M." June. A reliable and fine variety Rose-colored flowers.

3 feet ..............Each \$0.35, doz. \$3.50

“ var. Desboisii. "M." Flowers very much darker in color than the preceding.

2 to 3 feet ........... Each $\$ 0.35$, doz. $\$ 3.50$

" var. nana variegata (Variegated Dwarf Weigela). "M." Of dwarf habit and possessing clearly defined, silvery variegated leaves; flowers light pink.

2 to 3 feet .......... Each $\$ 0.40$, doz. $\$ 4.00$

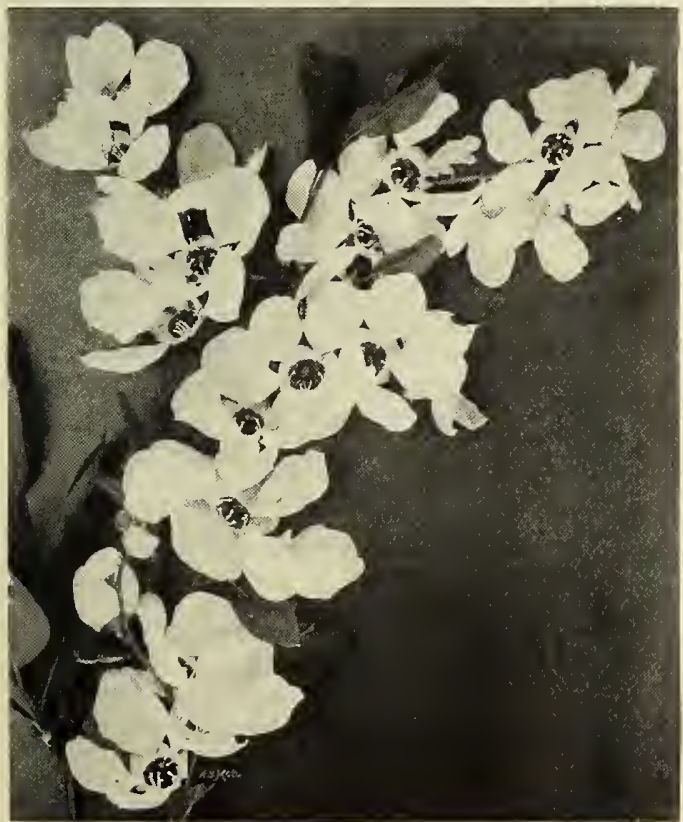

Exochorda-Pearl Bush.

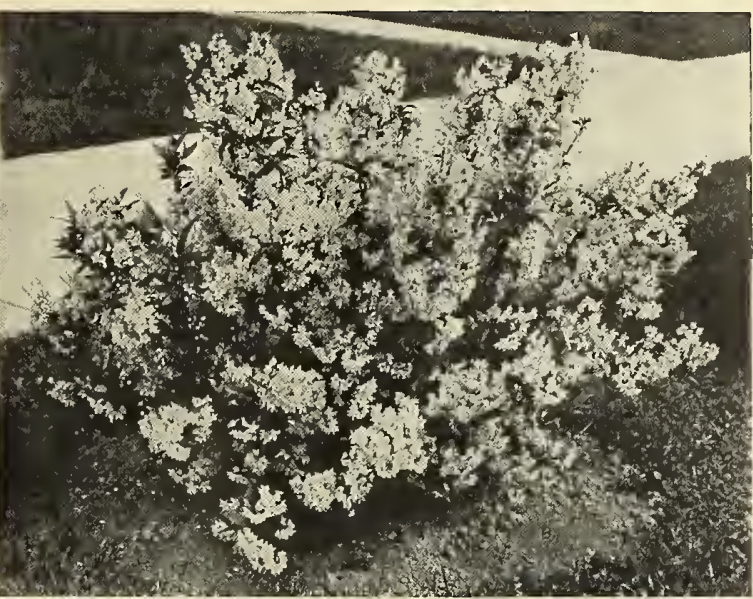

Deutzia gracilis.

"Eva Rathke. One of the best of the Weigelas, the plant having a vigorous habit and bearing freely, well-shaped, large, crimson-red flowers.

2 to 3 feet ................... $\$ 0.35$, doz. $\$ 3.50$ 3 to 4 feet $\ldots \ldots \ldots \ldots \ldots$... .50 , " $\$ .00$

\section{Elaeagnus - Oleaster}

Flaeagnus argentea (Silver-leaved Oleaster). "L." July and August. Flowers yellow; stems, leaves and fruit covered with silvery scales.

2 to 3 feet .......... Each $\$ 0.35$, doz. $\$ 3.50$

" edulis, or longipes (Japan Oleaster). "L." July. The leaves are smooth and dark green above, and covered on the lower surface with a dense, silvery-white pubescence. The small yellow silvery-white pubescence. The small yellow ingly ornamental.

2 to 3 feet ..........Each $\$ 0.35$, doz. $\$ 3.50$

\section{Euonymus - Strawberry, or Spindle Tree}

Fuonymus alatus (Winged Burning Bush). "L." A handsome shrub 6 to 8 feet tall, with corky winged branches. Native of China and Japan. Leaves oval, bright green, fading in Autumn with gorgeous tones of red and crimson. A capital shrub, attracting attention wherever seen.

2 to $21 / 2$ feet ........ Each $\$ 0.35$, doz. $\$ 3.50$

"Americanus (Strawberry Bush). "M." June. A slender growing shrub, with shining foliage and deep scarlet berries.

3 feet ............Each $\$ 0.35$, doz. $\$ 3.50$

" Europaeus (Spindle Tree). "L." May. Forms a low, round-headed tree, very compact. Folorange and red fruit of Autumn.

3 feet $\ldots \ldots \ldots \ldots \ldots$ Each $\$ 0.35$, doz. $\$ 3.50$

“ Europaeus var. latifolia. "M." A decorative, hardy and very rare species with foliage 3 to 4 inches long; large, showy fruit and peculiar. long, slender Winter buds.

3 feet ........................ $\$ 0.75$

" obovatus (Running Strawberry Bush). A low, procumbent shrub, the stems rooting wherever they come in contact with the ground. Leaves bright green from 1 to 2 inches long. Excellent for banks and dry places.

Each

$\$ 0.35$, doz. $\$ 3.50$

\section{Exochorda - Pearl Bush}

Frochorda grandiflora. "L." Its foliage is broad, lanceolate-ovate, sharp-pointed. The flowers are pure white, in racemes of five or six, with spoon-shaped petals, which are very narrow and stand apart at the base. A delicate fragrance adds to its charm.

$21 / 2$ to 3 feet ............................. $\$ 0.35$ 


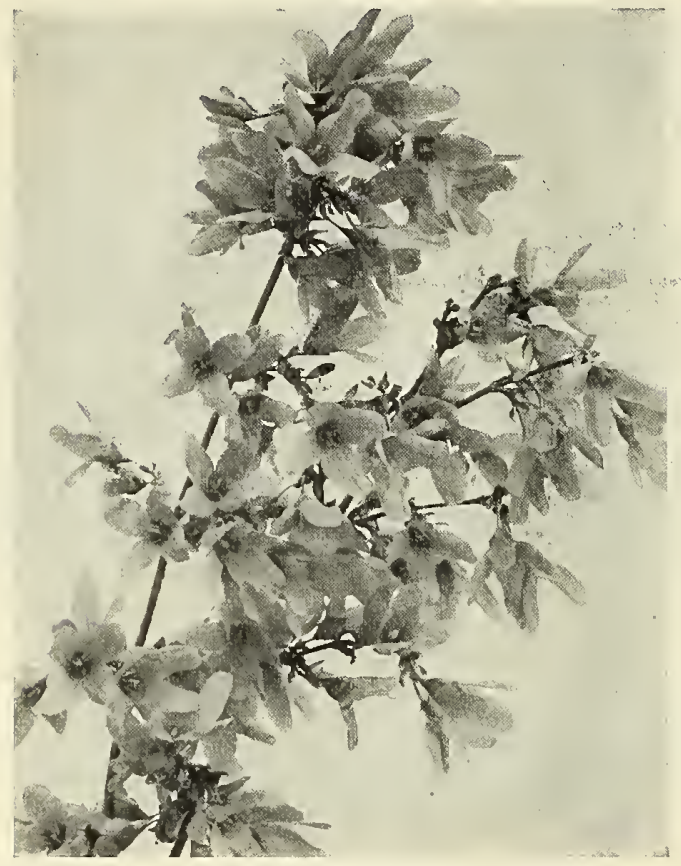

Forsythia Fortunel.

Forsythia - Golden Bell

Forsythia Fortunei (Fortune's Forsythia). "L." April. A spreading bush, with dark, shining foliage, which has a purplish tint in Autumn. Deep yellow flowers.

3 feet ............. Each $\$ 0.35$, doz $\$ 3.50$ intermedia. "L." This also is an erect-growing shrub, but when full grown the branches become arching and it resembles F. suspensa; the blossoms are much like the F. Fortunei; very floriferous.

3 to 4 feet .......... Each $\$ 0.35$, doz. $\$ 3.50$

" suspensa (Weeping Goiden Bell) "L" April. The long, willowy branches arch gracefully over to the ground and are covered to the tips with trumpet-shaped yellow flowers.

3 feet ............ Each $\$ 0.35$, doz. $\$ 3.50$

"viridissima. "M.," May. Stiff and bush-like habit, with deep green leaves and lighter flowers, blooming after the other varieties.

3 feet $\ldots \ldots \ldots \ldots \ldots$ Each $\$ 0.35$ doz. $\$ 3.50$

var. aurea (Golden-leaved Forsythia). New. In flowering and vigor of growth much like the Forsythia Fortunei, but the leaves, which are early in the spring a pale green, become a bright yellow, which color remains until late in the Autumn. A novelty of the greatest value. Strong plants.

Each ........\$0.50

\section{Gaylussacia - Huckleberry}

Gaylussacia frondosa (Huckleberry). Bears sweet bluish berries.

1 to $1 \frac{1 / 2}{2}$ feet ........................ $\$ 0.35$

\section{Genista - Broom}

This plant is of value in poor, thin soil, where nothing else can be made to grow.

Genista scoparia (Scotch Broom). "D." An evergreen plant, with rush-like leaves and large Pea-shaped flowers; the foliage is not hardy in New England, killing back to the ground during Winter, but makes annual robust growth, and is at home when grown in the sands by the sea.

sands by the sea.

"tinctoria (Dyer's Broom). This plant is quite prominent in the wild sections of eastern Massachusetts. It bears golden-yellow blossoms in June, and attracts attention when grown in masses. Is fine for rockeries and dry hill or for plantin hanks.

Each or for plantin hanks. $\$ 0.35$, doz. $\$ 3.50$

\section{Gleditschia}

(See Deciduous Trees).

\section{Halesia - Snowdrop Tree}

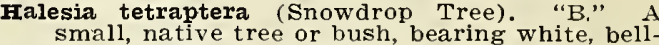
small, native tree or bush, bearing white, bell-
shaped flowers similar to the snowdrop, but much larger.

3 to 4 feet .........Each $\$ 0.50$, doz. $\$ 5.00$

\section{Hamamelis - Witch Hazel}

Hamamelis Virginica "L." November. Large foliage, with downy surface, and showy yellow flowers, appearing after the ripening of the leaves in November. The ripe seed is discharged as from a pop-gun. Grows in all soils.

2 to 3 feet ......... Each $\$ 0.35$, doz. $\$ 3.50$

\section{Hibiscus (Althaea) - Rose of} Sharon

The flowers appear in August and September when there is a scarcity of bloom in the garden.

Hibiscus Syriacus alba plena. "L." Double white Althaea.

3 feet .............Each $\$ 0.35$, doz. $\$ 3.50$

“ var, rosea plena. "L." Double pink Althaea. 3 feet .............. Each $\$ 0.35$, doz. $\$ 3.50$

"var. rubra plena. "L." Double dark red.

3 feet $\ldots . . . . . .$. Each $\$ 0.35$, doz. $\$ 3.50$

“var. purpurea. Single purple.

3 feet .............. Each $\$ 0.35$, doz, $\$ 3.50$

" var. purpurea plena. "I.." Double purple. 3 feet ............ Each $\$ 0.35$, doz. $\$ 3.50$

“ var. alba variegata. "L." Variegated white and red.

2 to 3 feet ......... Each $\$ 0.35$, doz. $\$ 3.50$

" var. folia variegata. "M." A fine and distinct variegated form, the leaves marked with light yellow. One of the best variegated shrubs.

2 feet ............. Each $\$ 0.50$, doz. $\$ 5.00$

“ var. totus albus. "L." Single. Pure white. One of the best.

2 feet $\ldots \ldots \ldots \ldots \ldots$ Each $\$ 0.35$, doz. $\$ 3.50$

We can furnish specimens of the above varieties, excepting the variegated leaved, in tree form, and with straight stems 3 feet high, at 75 cents each.

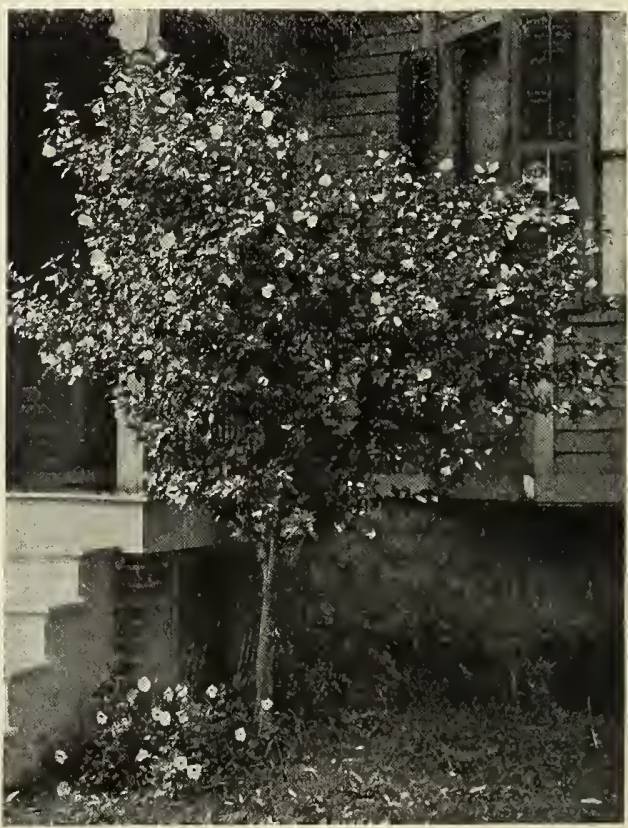

Iribiscus (Althaea). 


\section{Hippophae - Sea Buck-}

\section{thorn}

Hippophae rhamnoides (Sea Buckthorn). "L." A small tree or shrub that likes the vicinity of salt water. Foliage grayish white. Of an unusual color and very fine.

2 to 3 feet-

Each $\$ 0.35$, doz. $\$ 3.50$

\section{Hydrangea}

Ejydrangea arborescens grandiflora (Snowball Hydrangea). New. "M." The flower clusters are large, averaging 4 to 5 inches in diameter. Color is pure white, blooming at a time when flowers are scarce.

18 to 24 inches

Each $\$ 0.50$, doz. $\$ 5.00$ Ticulata. "L." September. The single form of Paniculata grandiflora, and valued highly in landscape planting, and should be more generally used.

$$
\text { 2. to } 3 \text { feet }
$$
ber. The fariety bearing immense come-shaped heads of white flowers, turning later to shades of pink and red. Given hard pruning every Fall its heads of bloom attain immense size.

$21 / 2$ to 3 feet .......... Each $\$ 0.30$, doz. $\$ 3.00$ Handsome specimens, in Tree Form, and with stems 3 to 4 feet high, 75 cents each.

\section{Hypericum - St. John's Wort}

Hypericum aureum. "D." July to September. The blossoms look, at a little distance, like fullblown Dandelions, covering a glossy, broadleaved bush.

18 to 24 inches .......Each $\$ 0.35$, doz. $\$ 3.50$

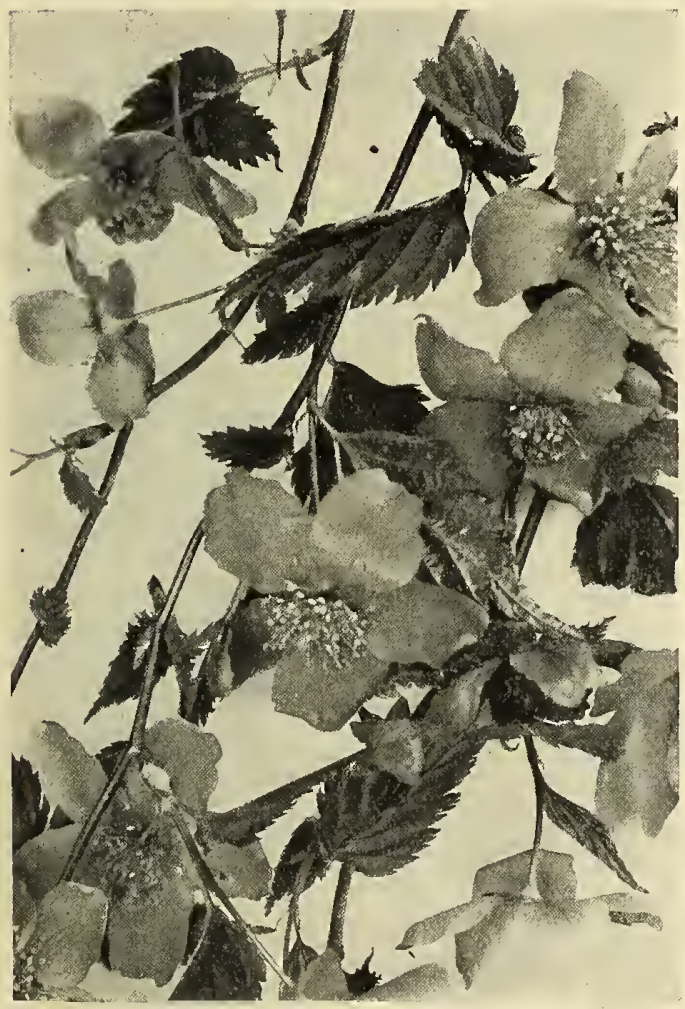

Hypericum (St. John's Wort).

Hydrangea paniculata grandiflora.

" densiflorum. "D." Individual flowers small but produced in great quantity. Very dense in growth. A beautiful dwarf shrub.

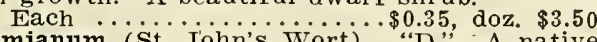

" Kalmianum (St. John's Wort). "D." A native shrub with rich green foliage and bright yellow blossoms.

24 inches ........... Each $\$ 0.35$, doz. $\$ 3.50$

"Moserianum. " $\mathrm{D}$," August and September This hybrid has a glossy foliage, with large, orangeyellow flowers. A charming shrub, requiring a little protection at Boston latitude.

2 years ...........Each $\$ 0.30$, doz. $\$ 3.00$

\section{Ilex - Holly}

Ilex verticillata (Black Alder). "M." June Glossy, dark green foliage and bright crimson berries late in Fall. Ornamental. 2 to 3 feet ......... Each $\$ 0.35$, doz. $\$ 3.50$

\section{Itea}

Itea Virginica "M" Of upright somewhat slender habit; the flowers appear late in June and are fragrant, white, in solitary, erect, dense, hairy racemes, giving it a greenish-white effect; the foliage changes to a rich crimson in June.

2 to 3 feet ......... Each $\$ 0.35$, doz. $\$ 3.50$

Kerria - Corchorus, Globe Flower

Kerria Japonica. "D." A valuable shrub, bearing single yellow flowers all Summer; in Winter
its green branches contrast in marked manner with other shrubs.

12 to 18 inches ...... Each $\$ 0$ 35, doz. $\$ 3.50$

" var. flore plena. Very double, deep yellow flowers.

2 to 3 feet .......... Each $\$ 0.35$ doz $\$ 3.56$

"var. foliis variegatis. "D." Fspecially good for its round, dwarf habit and finely variegateo silver and green leaves. Valued for planting edges of shrub borders.

12 to 18 inches ...... Each $\$ 0.35$, doz. $\$ 3.50$

\section{Lespedeza - Desmodium}

Lespedeza bicolor. "M." August. A Japanese shrub, exceedingly ornamental. The foliage resembles a Clover leaf, while the pink and white Pea-shaped flowers droop in profusior. from pendulous branches.

Strong plants ........ Each $\$ 0.30$, doz. $\$ 3.00$

" Sieboldi; syn. Desmodium penduliflorum (Sweet Pea Shrub). "D." September. Its annua! top shoots up to three and five feet high, and branches into multitudes of delicate, drooping sprays, which become simply masses of red and violet blossoms, always renewed, never ending, till the frosts of late October finally cut the whole top down.

Each ............\$0.35, doz. $\$ 3.50$ 


\section{Ligustrum - Privet}

Rapid growers in most situations and doing well in partial shade. Excellent for hedges or for association with other shrubs.

Iigustrum ciliatum. Comparatively small shrub. with spreading branches, 4 to 6 feet high. Leaves dark green, 1 to 2 inches long; flowers white; berries black, shining.

2 to 3 feet $\ldots \ldots \ldots$........ Each $\$ 0.25$, doz. $\$ 2.50$

"Ibota. "M." Juiy. A Japanese Privet of the most beautiful character. Dark, oval foliage, contrasting well with the prominent racemes of white, fragrant flowers. One of our best hardy hedge plants.

$21 / 2$ to 3 feet Each, $\$ 0.25$, doz. $\$ 2.50,100, \$ 15$. Ligustrum in "Ball Shape" can be used wherever specimen Box trees are used. Very ornamental. $21 / 2$ feet in diameter. Each $\$ 2.50$.

" ovalifolium (California Privet). "M." Very broad, oval-shaped leaves, which remain on well into the Winter. One of the most universal of hedge plants, and one of the best growing, doing especially well at the seashore.

18 to 24 inches Each Doz 100 18 to 24 inches $\cdots \cdots \cdots \cdots \cdots, \$ 1.00 \$ 6.00$

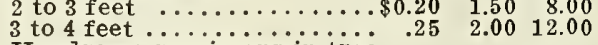

Handsome specimens in tree

form and 4 to 5 feet high, 1.0010 .00

"var. aureum (Golden California Privet). "M." A recent introduction of the greatest value. In habit of growth it is like the preceding. but its foliage is of the brightest yellow, and remains on the shrub until very late in Autumn. Excellent for color effect with other shrubs.

18 inches $\ldots \ldots \ldots \ldots$ Each $\$ 0.75$, doz. $\$ 7.50$

" vulgare (European Privet). "M." A valuable hedge plant, not so regular in growth as Ovalifolium, but hardier. Narrow foliage and showy white flowers, and profusion of black berries.

2 to 3 feet, Each, $\$ 0.20$, doz. $\$ 2.00,100, \$ 15.00$ " medium. One of the hardiest of the Japanese Privets, and valuable as a flowering shrub or hedge. Its oval foliage of deep green is augmented in June by showy clusters of fragrant, creamy-white flowers. Its glossy black berries in the Fall are no less ornamental.

2 to $3 \mathrm{ft}$... Each $\$ 0.25$, doz. $\$ 2.50,100 \$ 15.00$

\section{Lonicera - Bush Honeysuckle}

Ionicera Alberti, or hispida (Siberian Honeysuckle). "D." July and August. The bluishcolored leaves, very narrow, yet much larger than those of the common sorts, are thickly set on very slender, drooping branches. Flowers of a porcelain-blue color, are intensely fragrant, one often being sufficient to scent a whole room. Rare and desirable.

Each ................\$0.40, doz. $\$ 4.00$

" fragrantissima. "M." April. A beautiful variety; strong growth; fragrant pink flowers In early Spring. One of the best of shrubs. in to 3 feet "Morrowi. "L." "Juiy. O One of the finest berrybearing varieties, the fruit being a rich crimson, and remaining a long time. Vigorous habit; yellow flowers.

2 to 3 feet ........... Each \$0.35, doz. $\$ 3.50$

"Tatarica (Tartarian Honeysuckle). "L." June Bears a profusion of pink flowers.

2 to 3 feet .......... Each $\$ 0.35$, doz. $\$ 3.50$

" var. alba. Pure white, fragrant flowers.

2 to 3 feet ........... Each $\$ 0.35$, doz. $\$ 3.50$

"var. rubra. Red flowers in great profusion.

2 to 3 feet .......... Each $\$ 0.35$, doz. $\$ 3.50$

\section{Lycium - Box Thorn-Matrimony Vine}

Ifcium barbatum (Box Thorn). A hardy shrub, with slender, spiny stems; fruit brilliant crimson. Good in poor soil.

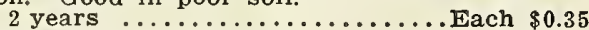

"Chinensis (Matrimony Vine). "M." More vigorous than the barbatum. Foliage grayish green; flowers varying from pink to purple, are set along the drooping branches. One of the best plants for covering rough places.

2 years ........................... $\$ 0.35$

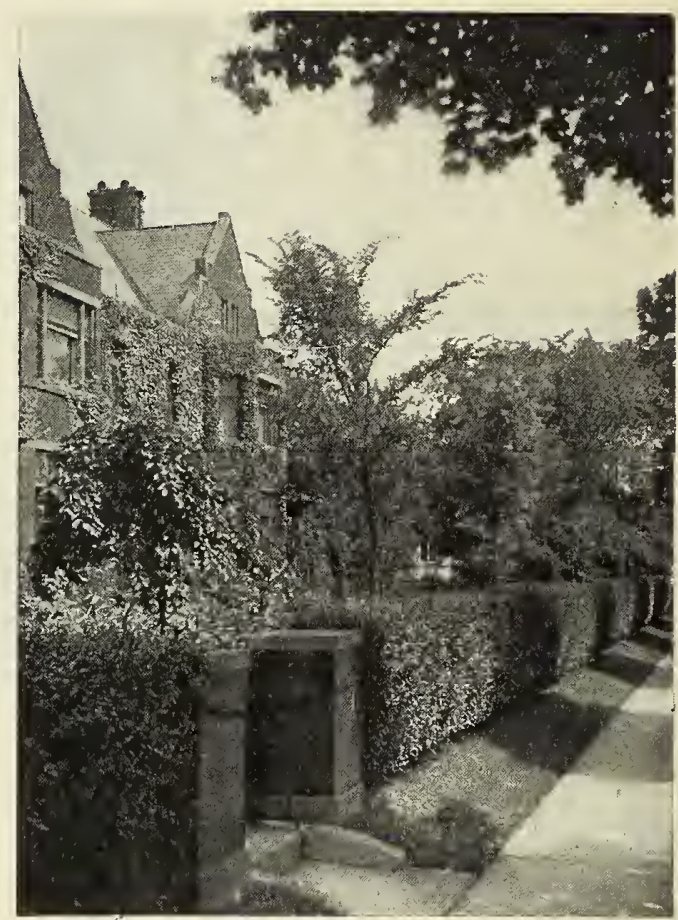

Ligustrum ovalifolium-California Privet.

\section{Myrica - Bayberry}

Myrica cerifera (Candleberry). "M." A low spreading native shrub; thrives in sandy places. It is a sub-evergreen and is admired for its dark green, fragrant foliage. The flowers are inconspicuous, followed by white, waxy berries.

12 to 18 inches ............ Each $\$ 0.35$

\section{Philadelphus - Syringa, or Mock Orange}

Philadelphus coronarius (Mock Orange). "L." June. One of the best. Pure white, fragrant flowers in dense clusters.

2 feet .............Each $\$ 0.35$, doz. $\$ 3.50$

" var. fi. pl. (Double-flowering Syringa). "M." Partially double, very fragrant flowers.

2 feet .................. $\$ 0.35$, doz. $\$ 3.50$ " var foliis aureis (Golden Syringa). "M." July. Of medium, dense growth, with golden-yellow foliage. A fine shrub for contrast with dark foliage.

12 to 15 inches ....... Each $\$ 0.35$, doz. $\$ 3.50$ " grandiflorus (Large-flowering Syringa). "L." June. One of the very best. Bears large, showy, scentless flowers.

3 to 4 feet $\ldots \ldots \ldots \ldots \ldots$. Each $\$ 0.35$, doz. $\$ 3.50$

" Iemoinei. "D." Hybrid. A choice and graceful variety; produces fragrant, pure white flowers in clusters in June.

2 feet ..................... $\$ 0.35$, doz. $\$ 3.50$

" var. Avalanche. "D." A graceful shrub, with slender, arching branches, covered almost the whole length with showy, white flowers. We regard it of greater value than almost any other shrub recently introduced

$11 / 2$ to 2 feet ......... Each $\$ 0.35$, doz. $\$ 3.50$

" Mont Blanc. "D." A charming variety of dwarf habit, with very large, fragrant flowers, produced in great abundance.

1 to 2 feet .................. Each $\$ 0.35$

\section{Potentilla - Cinquefoil}

Potentilla fruticosa (Shrubby Cinquefoil). "D." July to September. Yellow flowers, borne through the Summer. Narrow foliage.

18 to 24 inches ............. Each $\$ 9.35$ 


\section{Prunus - Plum and Almond}

Under this head are grouped the double-flowered Almonds, and Prunus triloba, all of which are among the very choicest of Spring-blooming shrubs.

Prunus maritima (Beach Plum). "M." April. Grows wild on Cape cod in sand. Splendid for seashore planting. Fine oval foliage Very pretty white flowers, followed by bright crimson fruit.

2 to 3 feet .......... Each $\$ 0.35$, doz. $\$ 3.50$

" pumilla (Sand Cherry). "D." April. A thick bush, bearing white flowers before the foliage. Black fruit. Equally valuable in sandy soil 2 to 3 feet ................. Each $\$ 0.35$

“ Pissardi (See Deciduous Trees).

" Sinensis alba plena (Dwarf White Almond). "M." May. The very double Rose-like white flowers fill the branches until they bend beneath the weight of bloom

2 to 3 feet ............ Each $\$ 0.50$, doz. $\$ 5.00$

“ var. rosea plena (Double Pink Almond). Similar to preccding, the flowers being rose colored. 2 to 3 feet ............ Each $\$ 0.50$, doz. $\$ 5.00$

"triloba (Double-flowering Plum). "L." May. A Chinese shrub, whose Spring beauty is difA cult to equal, The large, double pink fis resemble Roses, and are crowded along the slender branches, covering them completely. 3 feet ............. Each $\$ 0.50$, doz. $\$ 5.00$

\section{Ptelia}

(See Deciduous Trees).

\section{Pyrus (Aronia) - Chokeberry}

Pyrus arbutifolia. "L." May. A shrub with a densely branching habit. Foliage takes on the most vivid shades of red and crimson in the Autumn. It produces a mass of white blossoms, and the red fruit is the size of large peas, in flat bunches. Very ornamental.

$21 / 2$ to 3 feet ........ Each $\$ 0.35$, doz. $\$ 3.50$

\section{Rhodora}

Rhodora Canadensis (Canadian Rhodora). "S." May. A pretty shrub, growing wild over New England. Its attractive Rose-colored flowers come before the leaves. Glaucous foliage.

1 to 2 feet ......... Each $\$ 0.75$, doz. $\$ 6.00$

\section{Rhamnus - Buckthorn}

Thamnus Carolinianus, or frangula (Carolina Buckthorn). "L." June A thornless shrub or small tree, with greenish flowers, and black berries in Fall.

3 to 4 feet .......... Each $\$ 0.35$, doz. $\$ 3.50$

" cathartica (Common Buckthorn). "L." July. Excellent for hedges. Black fruit in Fall.

2 to 3 feet ........... Each $\$ 0.30$, doz. $\$ 3.00$ 3 to4 feet $\ldots \ldots \ldots \ldots \ldots$ " $\$$. 40 , " 4.00

" crenata, or Dahurica. A most beautiful shrub, with dark green, glossy leaves 4 to 6 inches long, or almost twice the length of the Common Buckthorn, of which it is a variety. Large, jet black berries remain on the bush all Winter. We consider this by far the best of the Buckthorns.

2 to 3 feet ......... Each $\$ 0.35$, doz. $\$ 3.50$

\section{Rhodotypus - White Kerria}

Rhodotypus rerrioides. "M." All Summer. An interesting, beautiful shrub from Japan. The Syringa-like flowers bloom through the season from May. Shiny black seeds in Fall

2 feet .............. Each $\$ 0.30$, doz. $\$ 3.00$

\section{Rhus - Sumach}

Rhus copallina (Shining Sumach) "M." August. Shining, lustrous foliage, which changes to rich crimson in Fall. Greenish-yellow flowers. Quite effective.

2 to 3 feet .......... Each $\$ 0.35$, doz. $\$ 3.50$

"Cotinus (Purple Fringe, or Smoke Bush). "L." The large masses of misty purplish flowers, which this bears in June, give it the name of Smoke Bush. The leaves change to varying colors in the Fall.

2 to 3 feet .......... Each $\$ 0.35$, doz. $\$ 3.50$ 3 to 4 feet $\ldots \ldots \ldots \ldots \ldots$. $\quad .50$, " 5.00

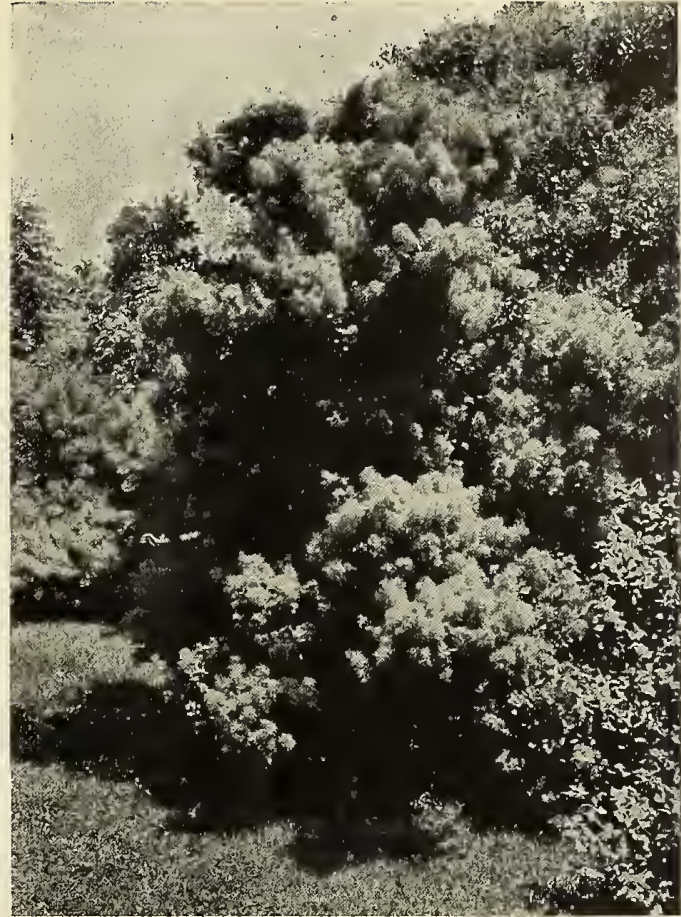

Rhus cotinus-Smoke Bush.

"glabra (Smooth Sumach), "L" June. Excellent foliage, topped in Autumn with prominent crimson heads of seed. Fine Autumn coloring. Good on rocky or poor soil.

2 to 3 feet .......... Each $\$ 0.35$, doz. $\$ 3.50$

" var. laciniata (Cut-leaved Sumach). "D." A most ornamental variety with finely divided, Fern-like leaves.

18 inches .......... Each $\$ 0.50$, doz. $\$ 5.00$

" typhina (Staghorn Sumach). "L." Grows generally in bush form to 10 feet in height; the foliage is compound, light green and of large size, and in Autumn is brilliantly colored. A most effective plant for grouping in masses; thrives on poor soil.

3 to 4 feet .........Each $\$ 0.25$, doz. $\$ 2.50$

"var. laciniata (Cut-leaved Staghorn Sumach). "L." A very graceful shrub, with delicate, Fern-like leaves, most brilliant in Autumn.

3 to 4 feet ......... Each $\$ 0.50$, doz. $\$ 5.00$

\section{Ribes - Currant}

Ribes alpinum (Mountain Currant). "D." May. Fragrant yellow flowers, good foliage. Dwarf compact habit. The best of the Ribes.

18 to. 24 inches ................. Each $\$ 0.50$

" aureum (Missouri Currant). "M." May. Early yellow flowers in showy racemes. Glossy foliage, which gives bright Autumn tints.

2 to 3 feet ........... Each $\$ 0.30$, doz. $\$ 3.00$

" sanguineum (Crimson-flowered Currant). "S." July. Carmine flowers of fine color, with handsome leaves. 2 to $21 / 2$ feet

Each $\$ 0.35$, doz. $\$ 3.50$

\section{Robinia - Acacia}

Robinia hispida (Rose Acacia). "M." A shrub bearing beautiful rose-colored flowers on long pedicles in May and June. Useful for planting in large masses. Will grow in any soil, and when in bloom is highly ornamental 2 to 3 feet ......................... $\$ 0.50$

\section{Bush Roses}

Under this head we include the varieties of our Native Wild Rose and others used for massing and general landscape planting. 


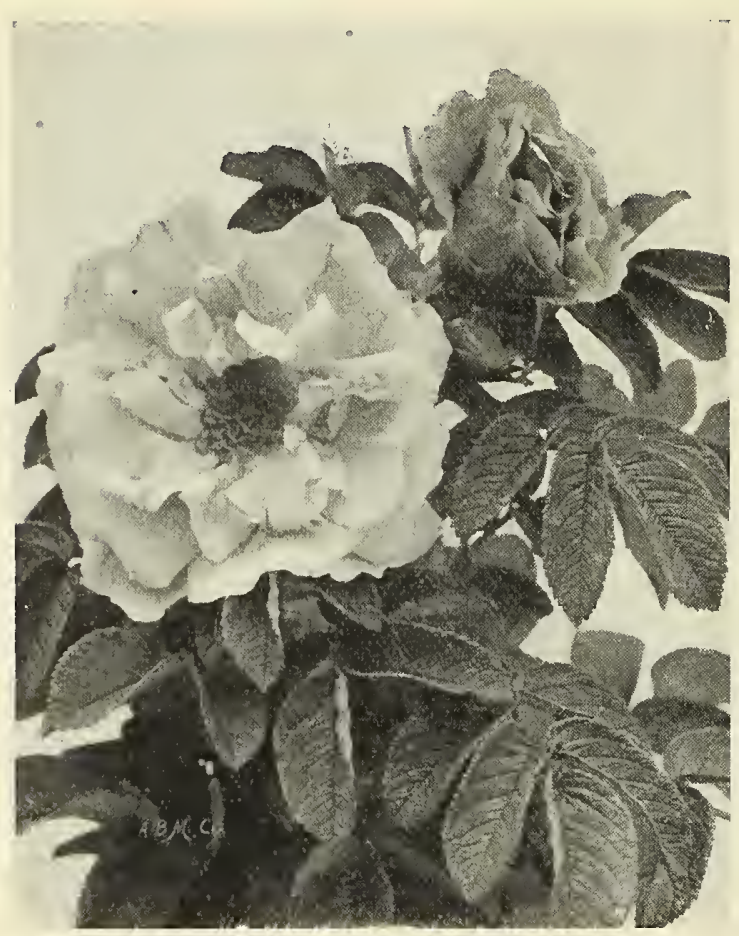

Rosa rugosa

\section{Rosa - Roses}

Rosa blanda (The Meadow Rose). The slender, red branches are almost thornless. Flowers pink; fruit red.

2 feet ............Each $\$ 0.25$, doz. $\$ 2.50$

"Carolina (The Swamp Rose). A tall-growing wild Rose, with single pink flowers and scarlet fruit.

1 to 2 feet .......... Each $\$ 0.25$, doz. $\$ 2.50$

" lucida. A dwarf native variety. Stems thickly covered with prickles. Flowers single, rosy pink.

18 inches ............ Each $\$ 0.25$, doz. $\$ 2.50$

"var, alba. A valuable new sort, with pure white flowers and green stems

12 inches ........... Each $\$ 0.50$, doz. $\$ 5.00$

" multiflora Japonica. Single, pure white flowers in clusters, small scarlet hips in Winter.

2 feet ..................... doz $\$ 0.25$, $\$ 20$

" nitida. Branches completely covered with bristles, bright pink flowers and fruit.

12 inches ........... Each $\$ 0.25$, doz. $\$ 2.50$

" rubiginosa (Sweet Brier). Sweet-scented foliage, pink flowers and orange-red fruit.

2 feet .............. Each $\$ 0.25$, doz. $\$ 2.50$

" rubrifolia (The Red-leaved Rose). Branches and leaves purplish red; flowers pink, fruit

scarlet. 2 feet ............ Each $\$ 0.35$, doz. $\$ 3.50$

"rugosa (The Ramona Rose). Leaves wrinleled, dark green above, pale beneath. Flowers pink or red. Fruit large, bright red.

18 to 24 inches....... Each $\$ 0.35$, doz. $\$ 3.50$

" var. alba (The White Ramona Rose). Same as above, with flowers pure white.

18 to 24 inches ...... Each $\$ 0.35$, doz. $\$ 3.50$

" Rugosa, var. Prostrata or Repens (Trailing Rosa Rugosa). This variety is a hybrid from the well-known Rosa Wichuraiana and Rosa Rugosa. It has the foliage and blossom of the latter and the vigorous growth and habit of the former.

Fach ...

setigera (The Prairie Rose). Long, slender branches, flowers in great profusion; deep rose Bright red fruit.

2 to 3 feet ......... Each $\$ 0.35$, doz. $\$ 3.50$ "spinossissima (The Scotch Rose). A low shrub with upright branches covered with spines. Leaves bright green, small. Flowers very numerous along the branches; pink, white or creamy-white. Fruit black. Each ............ \$0.50, doz. $\$ 5.00$

"Wichuraiana (The Memorial Rose). Used extensively in cemeteries, for covering embankments and stonework; it creeps rapidly over the surface, forming a mat of dark green foliage; flowers are pure white, borne in clusters, and fragrant.

Each ............ \$0.35, doz. $\$ 3.50$

\section{Rubus - Bramble}

Rubus odorata (Flowering Raspberry). "M." All Summer. A noble plant, with leaves 6 to 12 inches broad, and pink-purple blossoms, 2 inches across, in clusters, which continue to bloom all Summer. Very fragrant. One of the most useful plants for partially shaded places, for rustic planting or for groups.

2 to 3 feet ........ Each $\$ 0.35$, doz. $\$ 3.50$

\section{Sambucus - Elder}

Sambucus Canadensis (Common Elder). "L." June. Flat heads of flowers and reddish purple berries in Fall. Likes damp soil. 2 to 3 feet ........ Each $\$ 0.30$, doz. $\$ 3.00$

" nigra (European Elder). "M." July. Large spreading, picturesque shrub. Purpleblack berries.

3 feet .......... Each $\$ 0.30$, doz. $\$ 3.50$

“ var. aurea (Golden Elder). "L." A large, golden-leaved form. Requires the full sunlight, when it is one of the best of yellow shrubs.

3 feet .......... Each $\$ 0.35$, doz. $\$ 3.50$

“ var. laciniata (Cut-leaved Elder). "M." Elegantly cut leaves.

2 to 3 feet ............... Each $\$ 0.30$

" racemosus, or pubens (Scarlet-berried Elder). "L." A new shrub, with snowy-white flowers. May. Later, bunches of crimson berries. A fine shrub.

2 to 3 feet .........Each $\$ 0.50$, doz. $\$ 5.00$

\section{Shepherdia}

Shepherdia Canadensis (Buffalo Berry). A most beautiful shrub, much resembling the Eleagnus. It has very showy, edible fruit, which is much prized for household uses. Well adapted for planting on dry, rocky banks.

2 to 3 feet .......... Each $\$ 0.50$, doz. $\$ 5.00$

\section{Spiraea - Meadowsweet}

spiraea arguta. "M." Japan. Closely allied to the well-known early-flowering S, Thunbergii, which it resembles. It is, however, of more elegant habit than the latter, having larger flowers, borne on comparatively upright stems.

2 to 3 feet $\ldots \ldots \ldots \ldots$ Each $\$ 0.35$, doz. $\$ 3.50$

“ callosa (Fortune's Spiraea). "M." Deep rosered flowers in close clusters, lasting nearly all summer.

2 to 3 feet ......... Each $\$ 0.35$, doz. $\$ 3.50$

“ var. alba (Fortune's Dwarf White Spiraea). "D." All Summer. A pure white form and one of the best dwarf shrubs.

12 to 15 inches ....... Each $\$ 0.35$, doz. $\$ 3.50$

“ Japonica Bumalda (Bumald's Spiraea). "D." Grows as a low, round bush, producing numerous flat heads of rosy hue from Midsummer until Fall

18 to 24 inches ......Each $\$ 0.35$, doz. $\$ 3.50$

“ var. Anthony waterer. An improved form of the dwarf $\mathrm{S}$. Bumalda. Very low growing, and bearing flat heads of deep rose blossoms all through the late part of the Summer.

18 to 24 inches ....... Each $\$ 0.35$, doz. $\$ 3.50$

" opulifolia (Nine Bark). "L." June. A stronggrowing shrub, with white flowers along the stems.

$21 / 2$ to 3 feet $\ldots \ldots \ldots$ Each $\$ 0.35$, doz. $\$ 3.50$

" opulifolia aurea (Golden Sniraea). "L." One of the best of our yellow-leaved shrubs. Golden yellow all summer.

2 to 3 feet ........... Each $\$ 0.35$, doz. $\$ 3.50$ 


\section{SPIRAEA-Continued.}

“ prunifolia fl. pl. (Bridal Wreath). "M." Stronggrowing, irregular form. Small, round, shining leaves, of beautiful Autumn color; flowers double white, abundant in May.

2 to 3 feet ............ Each $\$ 0.35$, doz. $\$ 3.50$

" rotundifolia. "L." A rapid grower, with spreading branches and dark green, rounded foliage, which is held very late. The pure white flowers in June are very showy.

3 to 4 feet ............................ $\$ 0.50$

“ sorbifolia (Ash-leaved Spiraea). "S." July Handsome foliage, resembling the Mountain Ash. Long, showy panicles of white flowers. A fine Spiraea.

24 to 30 inches ......Each $\$ 0.35$, doz. $\$ 3.50$

“ Thunbergii (Thunberg's Spiraea). "D." April and May. Low-growing, rounded form, delicate, drooping, yellowish green, lanceolate foliage, which takes and retains the most lovely tints in Autumn. Small, abundant white flowers in May.

$11 / 2$ to 2 feet .......... Each $\$ 0.30$, doz. $\$ 3.00$

“Van Houttei (Van Houtte's Spiraea, or Large Bridal Wreath). "M." June. The finest and most satisfactory of all Spiraeas, either singly or among other shrubs. It forms a round and graceful bush with arching branches, which in June are set from end to end with the beautiful white blossoms. A shrub which cannot be overlooked.

2 to 3 feet ...........Each $\$ 0.30$, doz, $\$ 3.00$

\section{Stephanandra}

Stephanandra flexuosa. "M." One of the finest Japanese shrubs; of graceful habit, and spreading, drooping branches; handsome, deeply-cut foliage: in June, pure white flowers appear in panicled racemes; valuable for shrubberies or rocky banks.

2 to 3 feet ...........Each $\$ 0.35$, doz. $\$ 3.50$

\section{Symphoricarpos - Snowberry}

(These useful shrubs grow in any soil.)

symphoricarpos racemosus (Snowberry) "M." July. Bushy form, pink flowers in summer white, waxy berries in Autumn.

2 to 3 feet $\ldots . \ldots \ldots$...... Each $\$ 0.35$, doz. $\$ 3.50$

" vulgaris (Indian Currant). "S." Low-growing, spreading, graceful habit; foliage attractive noteworthy for the beauty of its clusters of red berries. A beautiful shŕrub and particularly useful for covering hillsides and rough places.

2 to 3 feet .........Each $\$ 0.30$, doz. $\$ 3.00$

\section{Syringa - Lilac}

syringa Japonica (See Deciduous Trees).

" Josikea (Chionanthus-leaved Lilac). "L." May Valued for its handsome, large, wrinkled leaves, and for its late-blooming quality Flowers are bluish-purple.

2 to 3 feet $\ldots \ldots \ldots \ldots$. Each $\$ 0.40$, doz. $\$ 4.00$

" ligustrina Pelcinensis. "L." A tall shrub of much beauty of foliage. Flowers white and very fragrant.

3 to 4 feet

Persica (Persian Tilac) "M" May and June. Habit more open and branches more slender and drooping than other Lilacs. Flowers light purple.

2 to 3 feet .........Each $\$ 0.35$, doz. $\$ 3.50$

“ var. alba (White Persian Lilac). "M." A pure white form of the above.

2 to 3 feet ........... Each $\$ 0.35$, doz. $\$ 3.50$

" Rothamagensis (Rouen Lilac). "M." May and June "Habit like the Persian; flowers intense violet; large, open heads.

2 to 3 feet ........... Each $\$ 0.35$, doz. $\$ 3.50$

" villosa. "L." A species from Japan. Color varies from light pink to almost blue. Valuable for late blooming. Out of bloom, the shrub forms a striking object on account of the dark, glossy, massive leaves.

2 to 3 feet .......... Each $\$ 0.50$, doz. $\$ 5.00$

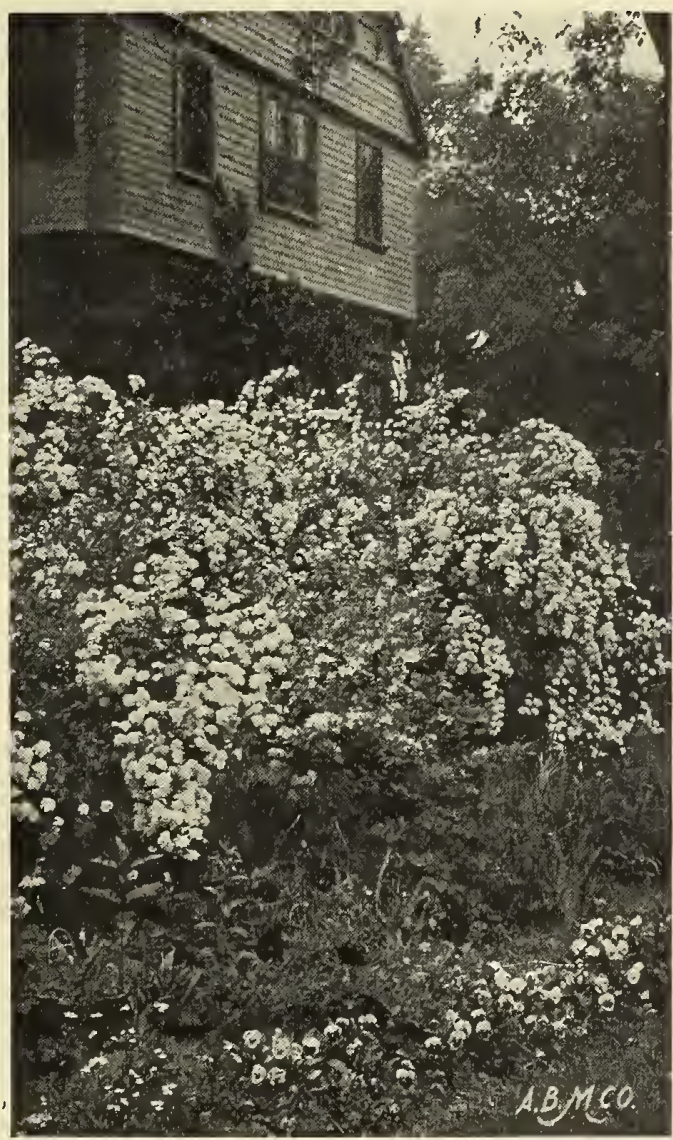

Spiraea Van Houttei

"vulgaris (Common Lilac). "L." May. Purple, fragrant flowers, large clusters.

2 to 3 feet ..................... $\$ 0.30$, $\$ 3.00$ 2 to 3 feet $\ldots \ldots \ldots \ldots \ldots$ Ea.ch $\$ 0.30$, doz. $\$ 3.00$
3 to 4 feet $\ldots \ldots \ldots \ldots$ 5 feet $\ldots \ldots \ldots \ldots \ldots \ldots \ldots$. $\quad .75$,

" var. alba (Common White Lilac). "L."

3 feet $\ldots \ldots \ldots \ldots \ldots \ldots$ Each $\$ 0.40$, doz. $\$ 4.00$

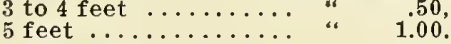

\section{Hybrid, or French Lilacs} SINGLE VARIETIES

These, together with the double varieties named below, are a decided improvement on the Commion Lilac, as' they flower while very young and produce immense trusses. Comparatively dwarf in growth, and seldom attaining a height of more than 6 to 8 feet.

All varieties 2 to 3 feet, each $40 \mathrm{c}$, doz., $\$ 4.00$

syringa alba grandiflora. Very large trusses of pure white flowers.

to

Each $\$ 0.40$

Charles $\mathbf{x}$. Magnificent clusters of dark red flowers, produced in the grandest profusion.

"Frau Bertha Dammann. This produces the largest cluster of white Lilacs of any species known in cultivation; the flowers are of the purest white.

Iouis Van Foutte. A well known sort, with large clusters of fine, bright red flowers.

" Iudwig Spaeth. The clusters are very large, and of splendid dark purple-red color; not only as buds, but even when the blossoms are fully expanded.

Marje Ie Graye. A dwarf grower; and one of the finest white varieties.

" rubra de Irarly. Purplish red, exceedingly free flowering. 


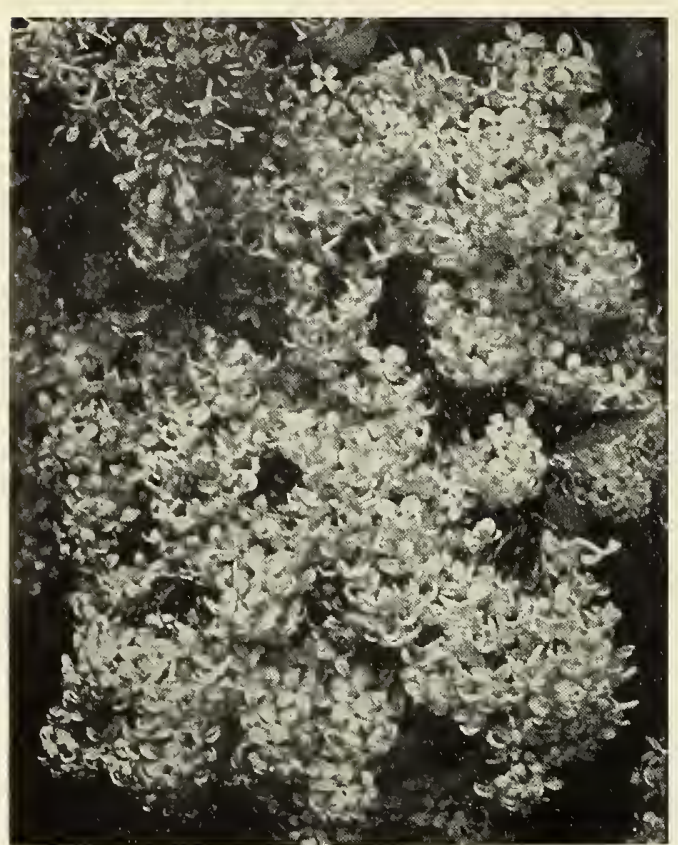

Syringa Mad. Lemoine.

SYRINGA-Continued.

\section{DOUBLE VARIETIES}

“Alphonse Lavallee. Trusses like a double Hyacinth, fine, blue, shaded to violet.

“ Belle de Nancy. Large, double pink, with white center.

“Ia Tour d‘Auvergne. Violet-purple, large, double; excellent.

“ Ieon Simon. Color bluish crimson; buds clear coral.

“ Mad. Cassimir Perier. Large trusses of very double, creamy-white flowers.

" Mad. Iemoine. A grand double white variety. Vigorous habit and immense foliage.

" Michel Buchner. Plant dwarf, bearing at the top of all the branches. Pale lilac throughout in half-opened blossoms, and also in the bud state.

“ President Grevy. Petals of a cobalt blue, with the center more brilliant and the edges rosy. The buds are of a violet blue.

“ President Carnot. Flower delicate tint of pale lilac, marked with white in the center. Season of flowering very late.

"Senator Volland. Dwarf, very brilliant; buds fuchsia-red; open flowers rose-red.

\section{Tamarix - Tamarisk}

Tamarix Africana. "M." June. Light pink flowers. 3 to 4 feet ........... Each $\$ 0.35$, doz. $\$ 3.50$ "Gallica (Common Tamarix). "M." July. Very showy in bloom. Pink blossoms. Later than the above.

3 to 4 feet ........... Each $\$ 0.35$, doz. $\$ 3.50$

\section{Vaccinium}

Vaccinium corymbosum (Blueberry). "D." Bunches of white flowers in May, followed by edible fruit in August.

Each ....................\$0.35

" Pennsglvanicum. "D." A low-growing Huckleberry.

Each ....................\$0.35

\section{Weigela}

(See Diervilla).

\section{Viburnum - Arrow-wood}

viburnum acerifolium (Dockmackie). "M." May and June. Maple-like foliage, with white flowers in flat heads, and showy clusters of purplish-crimson berries. Good in shady places.

1 to 2 feet ................. Each $\$ 0.35$ “ cassimoides. "M." June Flat heads of white flowers, and effective foliage Bears black berries in clusters.

2 to 3 feet ......................... $\$ 0.35$

" dentatum (Arrow-wood). "M." June. Glossy, handsome leaves, white flowers and fine steelblue berries in Fall.

3 to 4 feet .......... Each $\$ 0.35$, doz. $\$ 3.50$

“ Iantana (Wayfaring Tree). "M." May and June. Good size, bushy, large foliage, noteworthy for its silvery underlining; ornamental red, then black, fruit in Fall.

2 to 3 feet .......... Each $\$ 0.35$, doz. $\$ 3.50$

“ Ientago (Sheepberry). "M." Flowers creamy white; very fragrant; foliage a light, glossy green.

2 to 3 feet .......... Each $\$ 0.35$, doz. $\$ 3.50$

“ Opulus (High Bush Cranberry). "L." June. One of the best for general planting. The leaves are broad and elegant, and the Fallborne, bright searlet berries catch the eye late into the Winter.

2 to 3 feet ..........Each $\$ 0.35$, doz. $\$ 3.50$

" var. sterile (Common Snowball). "M." Filled with large pendant balls of snow-white fowers in May.

2 to 3 feet .........Each $\$ 0.35$, doz. $\$ 3.50$ Handsome plants in tree form.

5 to 6 feet high ............... Each $\$ 1.25$

" plicatum (Japan Snowball). "L." May. We consider this Japanese plant one of the finest shrubs in existence, both in flower and leaf. The plicated leaves are one of the great attractions of the plant. It forms a most symmetrical bush or single specimen.

2 to 3 feet ........... Each $\$ 0.40$, doz. $\$ 4.00$

"tomentosum (Japonicum). "L." Generally conceded to be the handsomest shrub shown for many years, and far more picturesque than even the famous $V$. plicatum of which it is the single or fertile form. Its dark, plicated foliage and massive cymes of bloom, which appear late in the Summer, are not equaled by any other shrub.

2 to 3 feet $\ldots \ldots \ldots \ldots$ Each $\$ 0.35$, doz. $\$ 3.50$

\section{Xanthorrhiza - Yellow Root}

Xanthorrhiza apilfolia (Yellow Root). "D." April. A native shrub of low growth, bearing racemes of Plum-colored, small flowers. Valued for its foliage and dwarf habit, and excellent for massing or covering dry or rough spots. Strong plants.

Each $\ldots \ldots \ldots \ldots \$ 0.25$, doz. $\$ 2.50,100 \$ 15.00$

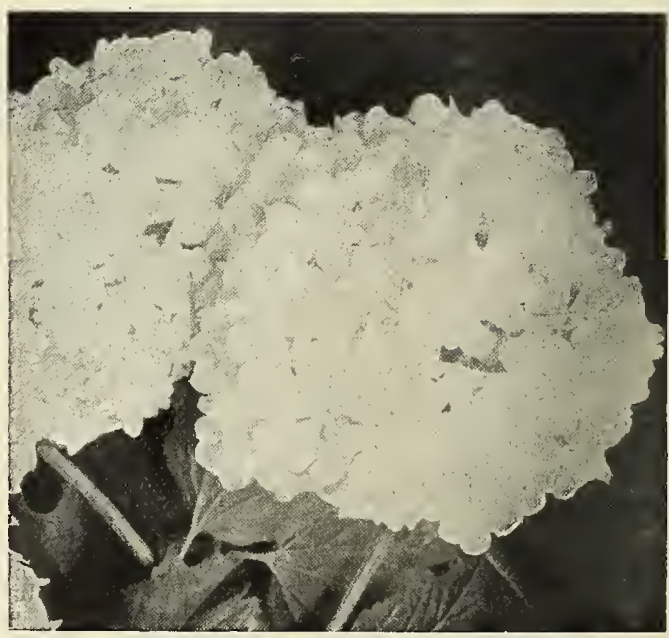

Viburnum opulus sterile (Common Snowball). 


\section{Bedford Quality Roses}

Great pro gress in Rose culture has been made in the last few years. From the ends of the earth new varieties and new spe cies are gathered, new hy b r d s are produced a $n d$ new seedlings are grown from which careful selections are made, and it is truly wonderful what the results have been to date. About all that is desirable in a Rose has been obtained in color, size, fragrance and hardiness.

\section{Cultural Directions}

Tocation - The best position for Roses is a southeast to southwest exposure. Roses require sunshine. They should be kept from shade and the roots of 2 rees. They like to be sheltered from the north and northwest winds We sometimes advise the planting of a shelter screen of Climbing Roses. This is ornamental and answers the purpose of a windbreak.

The Soil.-Roses do well in any good garden soil. Avoid too much sand, or ground which is stagnant. Be sure that the bed is well drained. Enrich with decomposed stable manure. Cow manure is preferable. Work this well into the soil.

Planting.-The planting of Roses may be done in October or November, or in April and May. Potted plants, of course, can be planted any time during the

plants, of course, can be planted any time during the surface of the ground. Spread the roots out as much as possible. When the hole is nearly filled in, tread the soil firmly with the foot.

Watering and Mulching.-When the planting is finished a good soaking with water will prove beneficial, should the ground be dry; then mulch well with coarse manure, and nature will do the rest. Water freely in dry weather only, and then in the early morning or late afternoon.

Pruning.-All Roses should be more or less pruned when planted. Cut back to within 4 or 5 inches of the ground, and at once after planting. When pruning older plants, which should be done in early Spring, cut out all the old wood, leaving three to six of the strongest shoots of last year's growth, cutting these back to within 6 or 8 inches of the ground.

Roses established in pots can be safely shipped and set out in the Spring and during the Summer. We carry in stock a large variety, including all the leading sorts. Price 25 cents each in advance of dormant plants.

\section{Hybrid Perpetual Roses!}

Strong, field-grown plants.

Price: Each $35 \mathrm{c}$, doz. $\$ 3.50$, except where

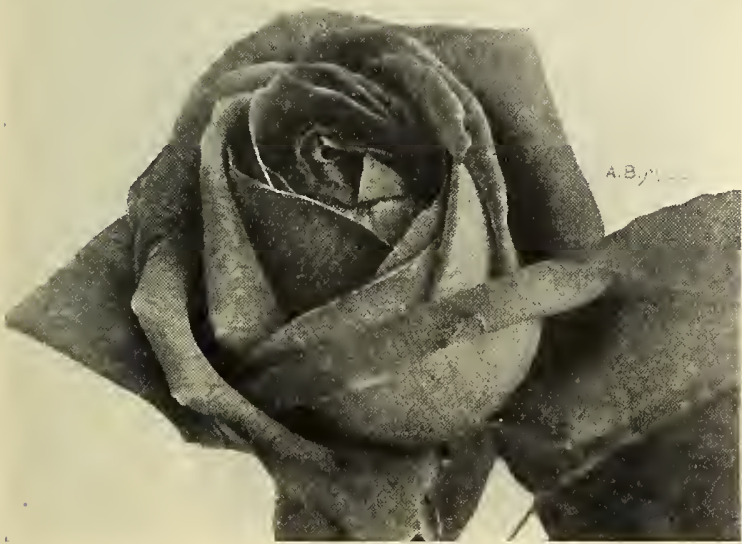

Alfred Colomb.

The following named Hybrid Perpetual Roses can be relied upon for hardiness. If planted in good soil, set in the ground to the proper depth, and pruned back as directed. they will produce quantities of bloom the first season. Deep planting and close pruning is very essential.

Alfred Colomb. Carmine red; very large and full.

American Beauty. Deep pink, shaded with carmine.

Anne de Diesbach. Clear, bright rose; large and fragrant.

Baron de Bonstetten. Velvety maroon; large and full.

Baroness Rothschild. Bright pink; very large.

Coquette des Blanches. White, medium size, flowers in clusters: very free. Each $50 \mathrm{c}$.

Coquette des Alpes. Large, full and wellformed, with very large petals; lovely pure white in color; fragrant; profuse bloomer; hardy. One of the very best of its class. 


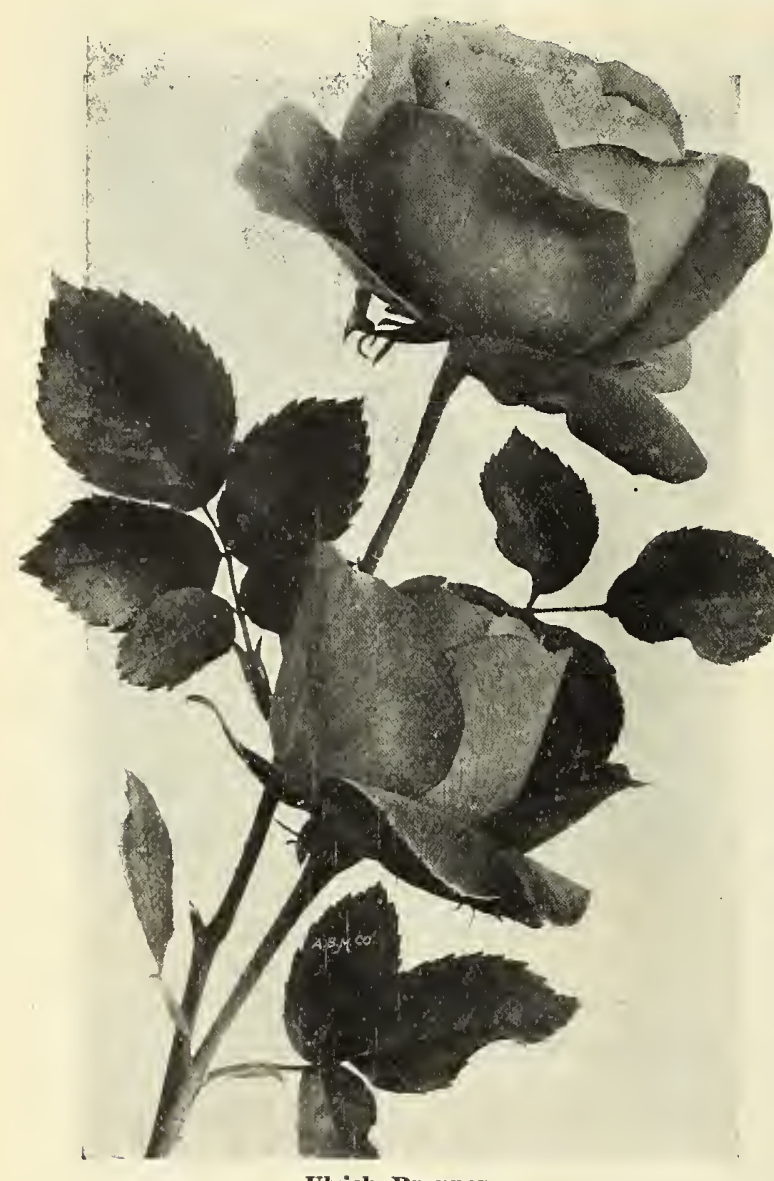

Clrich Brunner.

PERPETUAL ROSES-Continued.

risher Holmes. Brilliant carmine-crimson. Bush is vigorous and produces freely.

Erancois Ievet. Cherry red, medium, free bloomer. Frau Karl Druschki. White.

General Jacqueminot. Bright scarlet crimson Beautiful in all stages, from bud until petals fall.

Farrison Yellow. Deep sulphur yellow.

Fugh Dickson. Crimson, shaded scarlet.

John Fopper. Bright rose, carmine center.

Jules Margottin. Carmine rose.

Ia Reine. Clear, rosy pink.

Iouis Van Foutte. Reddish scarlet

Mabel Morrison. One of the best white Roses.

Mme. Gabriel Iuizet. Light, silvery pink.

Mme. Plantier. Pure white; early Summer bloomer.

Mme. Charles wood. Vivid crimson.

Magna Charta. Pink and crimson. Very large, full and double.

Marchioness of Iorne. Rosy pink.

Margaret Dickson. White, pale flesh color.

Marie Baumann. Brilliant carmine crimson; large, full; very fragrant.

Mrs. John Iraing. Soft pink; fragrant; blooms Mrs. John Iaing.

M. $\mathbf{P}$. Wilder. Cherry carmine. Excellent in hardiness and freedom of bloom.

Mrs. R. G. Sharman-Crawford. Color, deep rosy pink; flowers large and perfect; free bloomer.

Paul Neyron. Deep rose; very large.

Perle des Blanches. Pure white.

Persian Yellow. Bright yellow.

Frince Camille de Rohan. Deep velvety crimson.

Ulrich Brunner. Cherry red. A fine Rose.

York and Iancaster. Striped, red and white, Very old, yet much sought.

Each ............. \$0.50, doz. $\$ 5.00$

\section{Tea and Hybrid Tea Roses}

The following list contains only the hardiest varieties. If given a slight protection in Winter, they can be successfully grown anywhere in New England. Strong plants that will bloom the first season after planting. Set the plants very deep, and after bed has been leveled, prune back all branches to within 2 or 3 buds of the ground.

Price, except where noted: Each $40 \mathrm{c}$, doz. $\$ 4.00$

British Queen. Flowers pure white and of perfect form. One of the most beautiful white Roses existing. Each $\$ 1.00$.

Capt. Christy. Beautiful flesh color.

Caroline Testout (H. T.). Large, double, clear bright rose.

clothilde soupert. Pearly white, but variable, the same plant often producing red and white blooms.

Dean Hole. Silvery carmine, shaded salmon. Very distinct and free flowering. Each 50c., doz. $\$ 5.00$.

Double Fink Killarney. A distinct improvement on the common Pink Killarney. Each 50c. Fdward Mawley. Very deep carmine. Buds ]ong and pointed. Free flowering and very excellent. Each $\$ 1.00$.

Gloire de Dijon. Buff, with orange center

Grus an Teplitz. Dark red.

Hermosa. Bright rose, very double.

Jonkheer J. I. Mock. Clear imperial pink, reverse of petals rosy, silvery white. Large blooms freely produced on stiff stems. Strong grower

K. A. Victoria. Delicate creamy white, free flowering; quite hardy.

rillarney. Pink.

Killarney. White. Considered by many one of the best white garden Roses. Each $50 \mathrm{c}$.

Iady Ashtown. Very pale rose, base of petals yellow. Large and full. Each $50 \mathrm{c}$, doz.\$5.00.

Ia France. Silvery rose, changing to pink. Exceedingly sweet and handsome. Blooms soon after planting.

Iady Iillingdon. Deep golden yellow. Buds long and pointed. Very free flowering. Each $\$ 1.00$.

Iady pirrie. A delightful garden Rose. Deep coppery salmon with apricot tinted center. Each $75 \mathrm{c}$.

Iyon. (The Lyon). Flowers large and full with broad petals. Color salmon pink or coral red, shaded with chrome yellow. Very fragrant One of the finest. Each $50 \mathrm{c}$., doz. $\$ 5.00$.

mad. Jules Grolez. Bright China Rose, large, full and perfect form. Very floriferous. Each $\$ 1.00$.

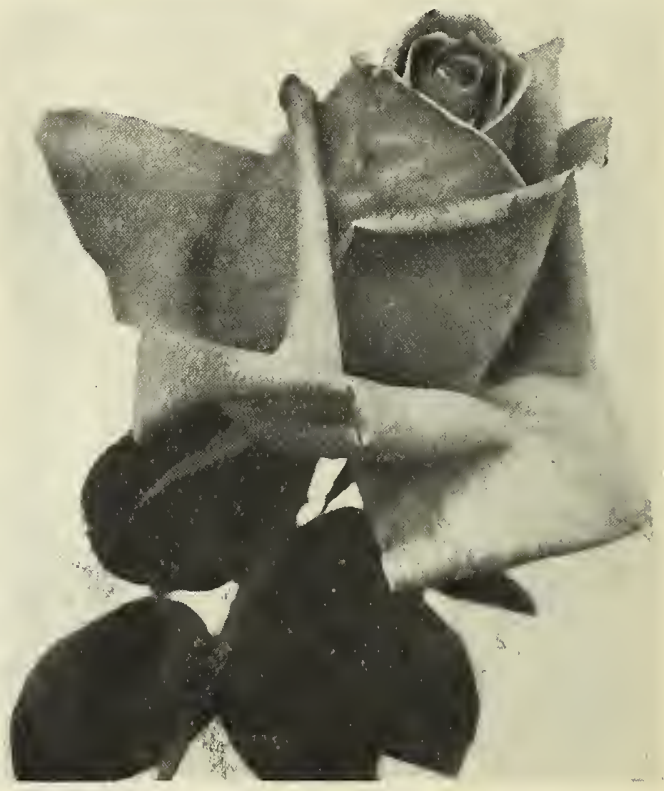

Jonkheer J. I. Mock. 
Maman Cochet. Clear carmine rose, salmon shaded. Maman White Cochet. Sport from Maman Cochet. Pure white.

Mrs. Aaron ward A most striking color. Indian yellow, shaded to lemon yellow at edges of petals. Very large and full. Each $75 \mathrm{c}$.

K. A. Victoria. Delicate creamy white, free flowering.

Prince de Bulgarie. Large and full. Deep rosy flesh, shaded with salmon. Each 50c, doz. $\$ 5.00$. soliel d'Or. Gold and orange to reddish gold. A color peculiar to itself. Each 50c., doz." $\$ 5.00$.

Sunburst Orange yellow, with deeper center. Long, pointed buds. Very free flowering. Each $\$ 1.00$

Viscountess Enfield. Coppery, shaded with yellow. Inner petals tinted carmine. Each $75 \mathrm{c}$.

\section{Moss Roses}

These are grown mostly for their beautiful, mossy buds. They require close pruning and high culture. Set plants deeply, and prune back to within 4 or 5 inches of the ground immediately after planting; but after the first year Moss Roses should not be pruned until at once after they have finished blooming

Strong 2-year plants, each $35 \mathrm{c}$, doz. $\$ 3.50$

Blanche Moreau. Pure white, large, full.

Crested Moss. Deep pink, buds surrounded with mossy fringe and crest.

Henry Martin. Fine rosy red.

\section{Hybrid Sweet Brier}

Like their parent, the common Sweet Brier, the foliage is deliciously scented. The flowers are single and of beautiful tints.

Strong 2-year plants: Each 50c, doz. \$5.00. Amy Robsart. Lovely deep rose.

Anne de Gierstein. Dark crimson.

Flora McIvor. Pure white, flushed with rose.

Belle Poitevine. Deep rose color. Flowers semidouble.

Meo Merrilies. Crimson.

Iord Penzance. Soft shade of fawn or ecru, passing to a lovely emerald yellow in the center; a good grower and abundant bloomer. very sweet scented.

\section{Rose Bradwardine-} Beautiful clear rose.

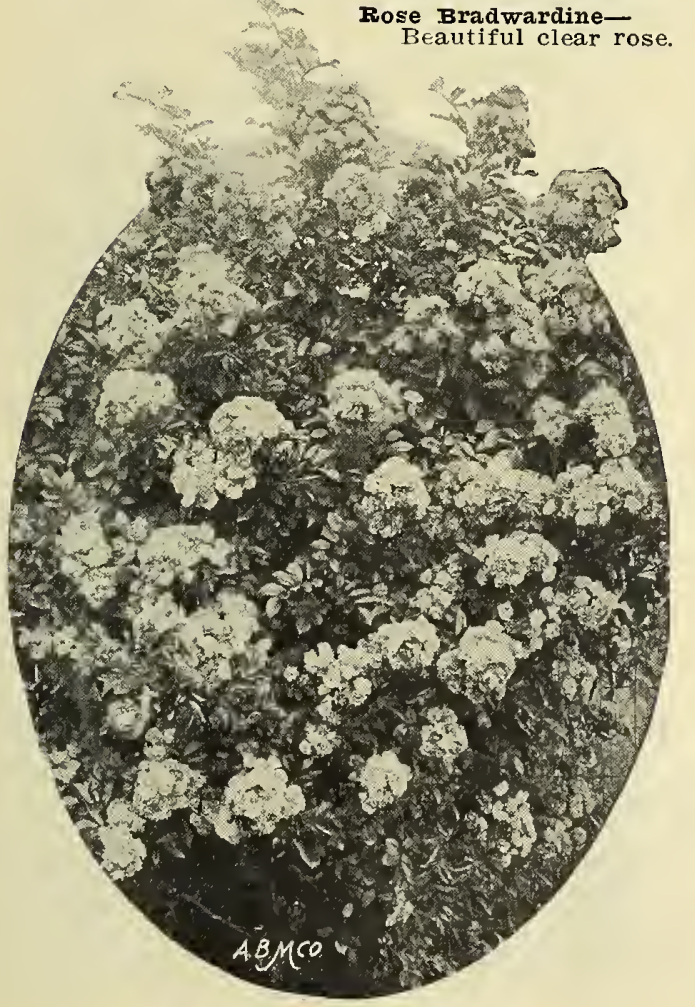

The Dorothy Perkins Rose.

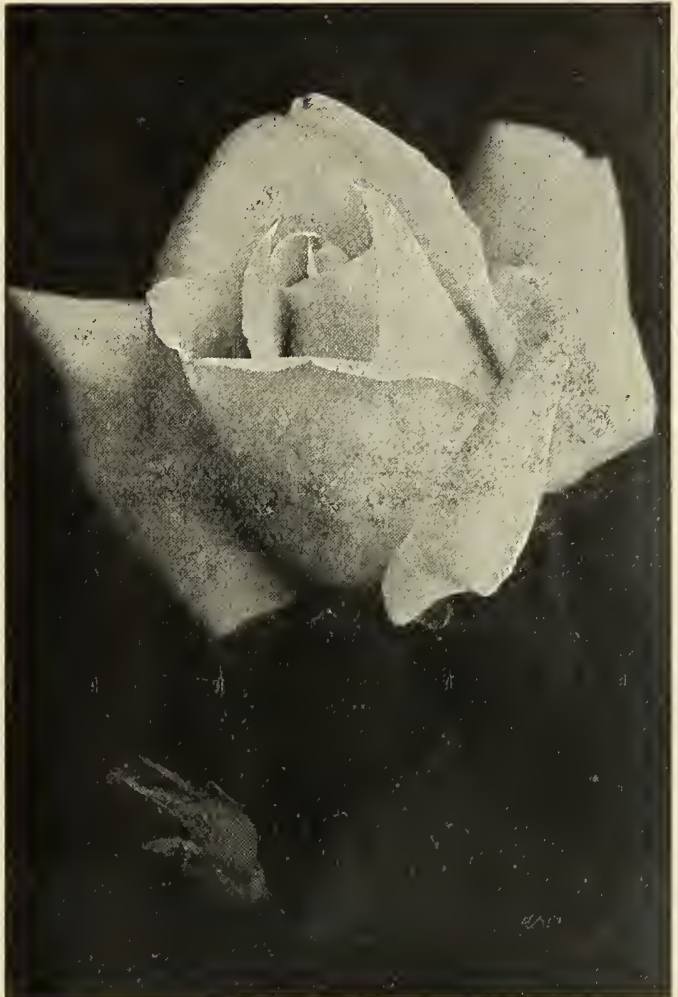

White Maman Cochet.

\section{Climbing and Rambler Roses}

Plant very deeply, and regardless of length of branches, prune back at once after planting to within 5 or 6 inches of the ground

Strong, field grown plants, each $35 \mathrm{c}$, doz. $\$ 3.50,100, \$ 25.00$, except where noted

Baltimore Belle. Pale blush, nearly white; double. Climbing American Beauty. Each \$1.50. (See New Roses).

Crimson Rambler. Clusters of bright crimson flowers in great profusion.

Debutante. A strong climber, with dark, glossy foliage. Clusters of bloom large. Color, light pink passing to white. Double Each $75 \mathrm{c}$

Dorothy Perkins Clear shell pink, very sweet scented. Foliage excellent Very vigorous. One of the best.

Excelsa. Each $75 \mathrm{c}$. (See New Roses).

Flower of Fairfield. The new, everblooming Crimson Rambler. A strong grower and continuous bloomer. Flowers bright crimson. Each $\$ 1.00$.

Fiawatha, Crimson and white. A new and beautiful variety. Each $50 \mathrm{c}$.

Lady Gay. Cherry pink.

Pink Rambler (Euphrosyne). Brilliant light carmine.

Queen of the Prairie Bright, rosy red, double. Tausendschon. Soft pink. New and good. Each

Trier. Pink. An everblooming pink Rambler of much value. Each $75 \mathrm{c}$.

wedaing Bells. Pink. Resembles much the D. Perkins Rose, but blooms later.

White Dorothy Perkins. White. One of the best yet introduced Each $50 \mathrm{c}$.

white Rambler (Thalia). Pure white, sometimes tinged with blush.

Yellow Rambler (Aglaia). Clusters of light yellow flowers

Veilchenblau (The Blue Rambler). A vigorous climber, producing immense panicles of blooms, opening reddish lilac and changing to amethyst and steel blue New. Each $75 \mathrm{c}$ The above named varieties are all hardy, and selected for their strong growth and free-flowering qualities. 


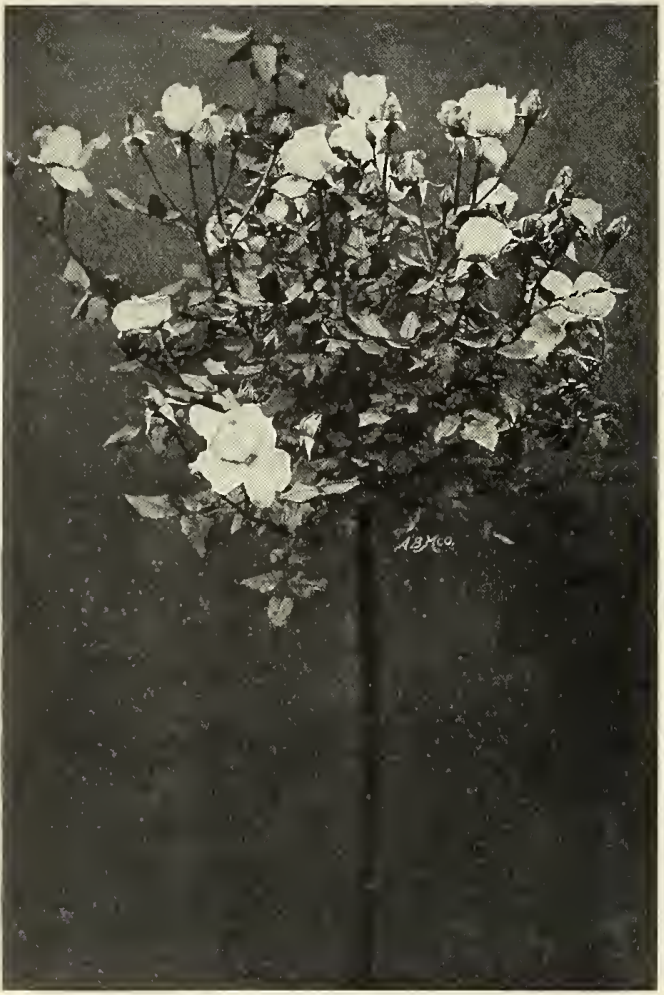

Standard or Tree Rose.

\section{Dwarf Bedding Roses, or Baby Ramblers}

A type of Rose which is becoming very popular for bedding purposes. They form shapely, compact, bushy specimens about 18 inches high, producing in great profusion from early in the season until severe frost, immense trusses of small flowers. Set deeply and prune back to within 3 or 4 inches of the ground.

Baby Dorothy. Nothing can surpass its beauty in a deep pink shade. It has all the flowering qualities of the famous Dorothy Perkins, but being dwarf, it is completely smothered in flowers throughout the Summer and Fall. Strong, field-grown plants. Each $35 \mathrm{c}$., doz. $\$ 3.50$.

Crimson Baby Rambler (Mme. Norbert Levavasseur). Crimson flowers similar to the popular climbing Crimson Rambler. Strong, 2year plants Each $35 \mathrm{c}$ doz $\$ 3.50$

Mrs. Wm. H. Cutbush. A beautiful cherry pink, and very free flowering. Strong 2-year plants. Each $35 \mathrm{c}$. doz $\$ 3.50$.

White Baby Rambler (Catherine Zeimet). Pure white flowers, showing the yellow stamens very prettily, produced in large, candelabrashaped trusses. Strong, 2-year plants. Each $35 \mathrm{c}$. doz $\$ 3.50$

\section{Trailing, or Memorial Roses}

Excellent for cemetery planting or covering embankments.

Price: Each 35 c., doz. $\$ 3.50,100 \$ 25.00$.

Fvergreen Gem. Foliage nearly evergreen. Flowers double, rich bronze color.

Gardenia. A vigorous grower, bud bright yellow, opening cream color.

Manda's Triumph. Large, double white.

Pink Roamer. Single, bright pink.

South Orange Perfection. Soft blush pink.

Universal Favorite. Large double pink.

Wichuraiana. The true Memorial Rose. Creeps rapidly over the surface forming a mat of dark green foliage. Flowers pure white, borne in clusters.

\section{Rugosa Hybrids}

This very interesting group is of Japanese origin and possesses some wonderful characteristics. The plant is very ornamental, having a rich, plicated foliage.

Agnes Emily Carman. Flowers in clusters; brilliant crimson, of the shade of General Jacqueminot; very free blooming, and continuing in bloom nearly all summer; a rampant grower, handsome foliage, and very hardy.

Conrad Frederick meyer. Clear, silvery rose; very fragrant, very vigorous, but well formed like La France. Each $50 \mathrm{c}$.

Madam George Bruant. Buds long and pointed, semi-double when open, white and fragrant, borne in clusters through the season. vigorous and hardy. Each $50 \mathrm{c}$.

New Century. Cross between everblooming Rose Clothide Soupert and Rugosa alba. Very hardy and a continuous bloomer. Color a bright rosy pink, with bright red center. Petals bordered with a creamy white. Each $75 \mathrm{c}$.

Rosa rugosa var. prostrata (Trailing Rosa rugosa). This variety is a hybrid form of the well: known Rosa Wichuraiana and Rosa rugosa. It has foliage and blossoms of the latter and the vigorous growth and habit of the former. Each $75 \mathrm{c}$

Sir Thomas Iipton. A new double white rugosa. Each $50 \mathrm{c}$.

Roseraie de l'Hay. A new hybrid rugosa of which we cannot speak too highly; a good grower; flowers very double; color carmine cherry red: a free bloomer and exquisitely scented. A most desirable acquisition. Each $75 \mathrm{c}$.

Rugosa alba. Single, pure white, having five petals and highly scented. Each $35 \mathrm{c}$.

Rugosa rubra. Single, bright rosy crimson, succeeded by large, brilliant berries of much beauty. Each $35 \mathrm{c}$.

\section{Standard Roses, or Roses in Tree Form}

We offer the following varieties of Roses grafted on stems $3 \frac{1 / 2}{2}$ to $41 / 2$ feet high.

Price: Each $\$ 1.00$, doz. $\$ 10.00$

John Hopper.

Paul Neyron.

Killarney.

F. T. Druschki.

Mragra Charta.

Ulrich Brunner.

Grus an Teplitz.

General Jacqueminot.

Mrs. Jno. Iaing.

Mad. Gab. Iuizet.

Crimson Rambler.

Dorothy Perkins.

Pink Baby Rambler.

Crimson Baby Rambler.

\section{Garden Books}

Of the many garden books offered we know of no one more useful to the amateur gardener than IKirkegaard's Handbook of Gardening. It contains just such information as one requires in making the best selection of varieties and to properly care for hardy plants and trees. Practically everything worth growing is described. The flowering season of each plant is given, its ultimate height, color of bloom, etc. Also articles on insects, spraying, pruning, planting and preparation of soil. A copy should be found in the house of every plant lover. We will furnish this book containing 400 pages and beautifully bound for $\$ 2.50$.

Special Offer to Our Customers To parties who favor us with orders for nursery companying order) we will furmish for the price of $\$ 1.00$, a copy of Kirkegaard's Fand book of Gardening. 


\section{Vines and Climbing Shrubs}

\section{Actinidia}

Actinidia polygama, or arguta. A strong-growing climber from Japan. Foliage large and green and flowers white, with a purple center.

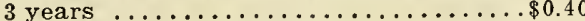

\section{Akebia}

Akebia quinata. May. One of the best Japan vines, with beautiful,

Each $\ldots . . . . . . . .$.

\section{Ampelopsis - Woodbine}

Ampelopsis quinquefolia (Common Woodbine, or Virginia Creeper). A native vine, most vigorous in growth. Intense crimson leaves in Autumn.

3 years $\ldots \ldots \ldots \ldots$ Each $\$ 0.25$, doz. $\$ 2.50$

"var. Engelmanni. A variety of the above, with stronger tendril discs, that cling like an lvy to any surface.

3 years ............ Each $\$ 0.30$, doz. $\$ 3.00$

"Veitchil (The Japan, or Boston Ivy). Used generally, notably in Boston, to cover walls, its fine shoots extending to the roofs of tall buildings. In the Fall the leaves assume the most gorgeous and varied tints. The vine can be made to cling even to wood. The young plants require for a year or more some covering in Winter.

3 years, No. $1 \ldots \ldots \ldots \ldots \ldots$ Each $\$ 0.35$

\section{Aristolochia - Pipe Vine}

Aristolochia Sipho (Dutchman's Pipe). A vine with immense heart-shaped leaves, very dense and, when well established, of most rapid growth. Its brown flowers are shaped like a pipe, and are very interesting.

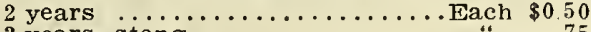

3 years, stong .............. $\quad .75$

\section{Bignonia}

(See Tecoma).

\section{Celastrus - Bittersweet}

Celastrus paniculatus. (Bittersweet). Assumes a shrub-like form, unless given an opportunity to climb; crimson fruit; from Japan.

3 years $\ldots \ldots \ldots \ldots \ldots \ldots \ldots \ldots$ Each $\$ 0.25$

" scandeng (Roxbury Waxwork). This beautiful old shrubby climber is brilliant through $\mathrm{Au}$ tumn and Winter, filled with its clusters of orange and crimson-capsuled fruit. The leaves are glossy and fine. Good in any situation. Excellent for planting near rocks or for covering dry banks.

3 years $\ldots \ldots \ldots \ldots \ldots \ldots \ldots \ldots$ Each $\$ 0.30$

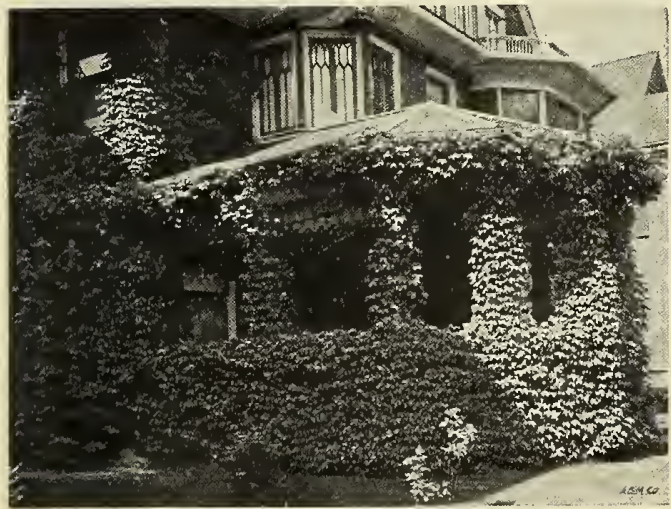

Ampelopsis Veitchil-Boston Ivy

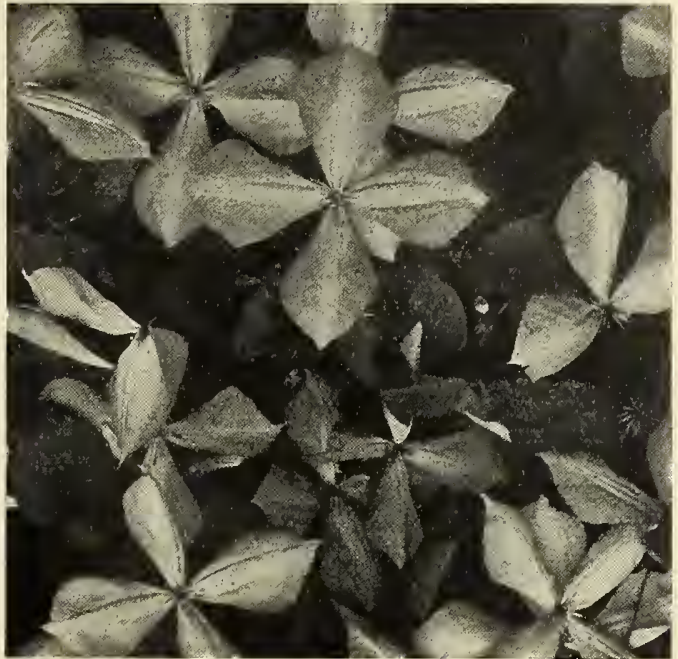

Clematis Jackmani.

\section{Clematis}

Clematis coccinea (Scarlet Clematis). All Summer. A strong climber, with light green foliage and showy, bell-shaped, brilliant scarlet flowers produced in great profusion.

2 years $\ldots \ldots \ldots \ldots \ldots \ldots \ldots \ldots$. Each $\$ 0.50$ " montana. A vigorous climber, resembling much the C. paniculata. Its white, sweet-scented flowers are produced in June. Leaves glossy and large. New.

Each ..................\$0.50 " paniculata. Being a rapid and vigorous climber, it can be depended upon to clothe large spaces quickly. It was originally introduced from Japan, and is allied to our native Virgin's Bower. The flowers, borne in long panicles, are white, and their fragrance is perceptible a long distance from the plant. They open near the latter part of August, and continue in flower for nearly a month.

2 years $\ldots \ldots \ldots \ldots \ldots \ldots \ldots \ldots$ Each $\$ 0.25$

giniana (Virgin's Bower). August. A strong climber, with dark green foliage and very pretty white flowers; the bunches of seed have long, woolly tufts, making them very ornamental for winter decoration

3 vears .......... Each $\$ 0.35$, doz. $\$ 3.50$

The New Clematis New England

"var. New England. This beautiful variety was introduced first by us, two years ago. It is a hybrid between C. paniculata and C. Davidiana, having the foliage and bloom of the latter and the hardiness and vigorous climbing growth of the former.

2 year plants $\ldots \ldots \ldots \ldots \ldots \ldots$.......... $\$ 0.50$

\section{Hybrid Large-Flowered Clematis}

Clematis Duchess of Edinburgh. Double, white, sweet scented

2 years .................Each $\$ 0.50$

"Henryi. One of the best whites. Large creamy white.

2 years ............................ $\$ 0.50$

" Jackmani. A general favorite. Violet purple and free flowering.

2 years $\ldots \ldots \ldots$ Fach $\$ 0.50$

" Madam Andre. ' ${ }^{2}$ vivid crimson Clematis of large size, and borne as freely as the wellknown Jackmani. 2 years

Each $\$ 0.50$

"ville de Iyon. New. This beautiful new Clematis of the Jackmani type cannot be too highly recommended. The flower is large, bright red, and the vine is completely smothered, when in bloom. Each 


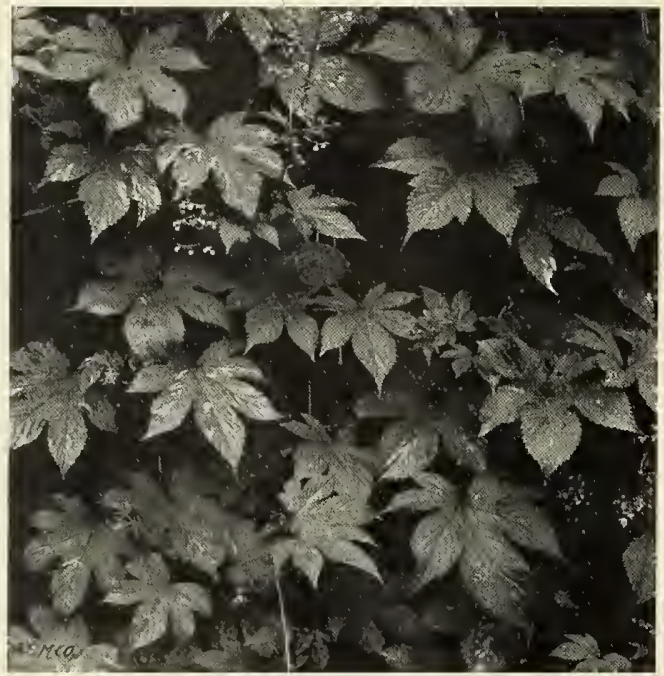

Humulus-Hop Vine.

Dolichos - (Pueraria) Kudzu Vine

Dolichos Japonicus (Kudzu Vine). An extremely fast-growing vine with immense leaves, bearing small racemes of rose purple, pea-shaped flowers toward the close of August

Strong roots ............... Each $\$ 0.50$

\section{Humulus - Hop Vine}

Humulus lupulus. (Hop Vine). Strong grower. Hops appear in July and August. Good for covering fences around poultry yards, as chickens will not pick leaves.

Each ..............\$0.25, doz. $\$ 2.50$

" var. aurea (Golden-leaved Hop Vine). A recent introduction of much value. In growth it resembles the common Hop vine, being equally as vigorous, but its foliage is of the brightest golden color. Very hardy.

\section{Lonicera - Honeysuckle}

Ionicera brachypoda (Chinese Evergreen Honeysuckle). Like Hall's Honeysuckle, except that the leaves are much darker and the flowers more fragrant. Yellow; very fine.

" vax Halleana "Haij's Evergreen Honeysuckle) All Summer. More generally used than any other variety. Deep green foliage, which is almost evergreen through the Winter, the fragrant yellow and white flowers blooming from Midsummer until frost.

2 years

Each $\$ 0.35$

- flexuosa var. aurea reticulata (Golden Variegated Honeysuckle). Leaves variegated gold and green. Slower in growth than former variety. ariety.

Periclymenum Belgicum (Beigian, or Dutch Monthly Honeysuckle). AlI Summer; red and yellow, very fragrant flowers in clusters. Each

sempervirens (Scarlet Trumpet Honeysuckle) This bears during the summer clusters of scarlet tubular flowers, and is one of the freest and best varieties. Handsome in foliage and fruit.

3 years

\section{Periploca}

Periploca Graeca (Grecian Silk Vine) A fastgrowing twining vine, with glossy, dark green leaves and small purple flowers. Native of southern Europe.

2 years $\ldots \ldots \ldots \ldots \ldots \ldots \ldots \ldots$................. $\$ 0.35$

\section{Polygonum}

Polygonum Baldschuanicum. A perfectly hardy, climbing plant, fairly smothered with feathery snow-white flowers, delicately suffused with pink, borne in long racemes. Very rare and beautiful.

Each
Tecoma (Bignonia) - Trumpet Vine

Tecoma radicans (Bignonia) (Trumpet Vine). The scarlet trumpet flower. Handsome, dark green foliage and showy clusters of orange and scarlet flowers during the Summer. We have not found any other varieties of Bignonia reliably hardy in New England.

Each .......................\$0.35

\section{Vitis}

Vitis coignetiae, or Crimson Glory vine. Its foliage is very broad, after the style of the Dutchman's Pipe, but its valuable quality rests in its remarkably brilliant coloring in the Autumn, when each one of its large, leathery leaves takes on a glowing crimson color. It is quite hardy.

Each

$\$ 0.75$

" heterophylla. A handsome climbing plant with deeply lobed leaves, sometimes sprinkled with white and pink. Good for low trellis work. Clusters of light blue, showy berries.

Each ....................... \$0.50

" var. dissecta, or aconitifolia (Cut-leaved Vitis). A variety of the preceding, with finely cut foliage. Very ornamental and rare.

Each ....................\$0.75

" var. tricolor (Tricolored Grape). A beautiful vine, with the most brilliantly colored foliage imaginable. The leaves are deeply cut, and marbled with white, pink and green. New and rare.

Each .....................\$1.50

“ Iabrusa (Fox Grape). A rapid climber with large, thick, deep green leaves, and purpleblack or red-brown berries. Good for covering trees, steep banks, rocks or coarse trellises.

Each .................... \$0.40

“ riparia, or vulpina (Frost Grape). Resembles the preceding, but with very sweet-scented flowers and small purple-black berries.

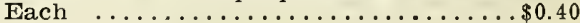

\section{Wistaria}

Wistaria Chinensis (Chinese Wistaria). A hardy, fast and tall growing climber, with pale green compound foliage, and' foot-long clusters of purplish, Pea-shaped flowers, borne profusely in May. The popular Wistaria.

Strong plants ................ Each $\$ 0.50$

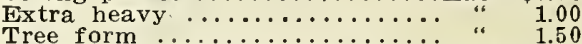

" var. alba. A white-flowered variety of the above. Strong plants ................ Each $\$ 0.50$ Extra heavy .................. 1.00

"frutescens (Shrubby Wistaria). A native Wistaria; less vigorous in habit than the Chinensis; flowers pale blue, in clusters. May.

Each ......................\$0.50

"var. magnifica. Resembles Frutescens, but the clusters are larger and denser; lilac-colored flowers with yellow spots; fragrant.

Each .......................\$0.50

" multijuga. From Japan. Distinguished from W. Chinensis by the longer and looser racemes of flowers. Dark purple. Hardy.

Each ......................\$0.75

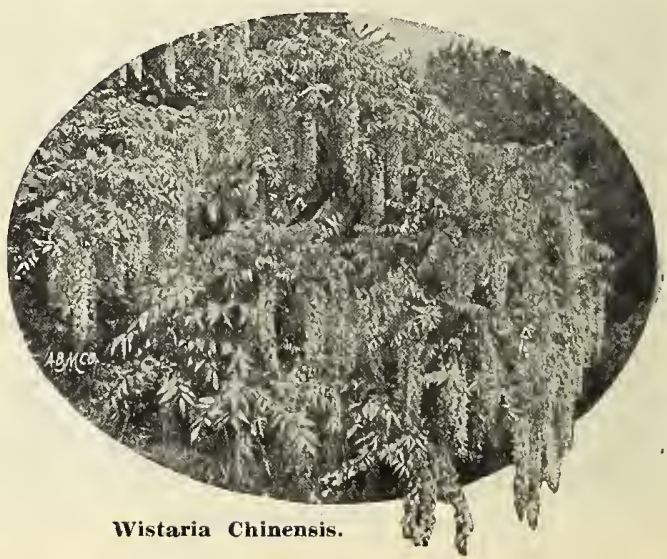




\section{New England Collection of Hardy Herbaceous Perennials}

A quantity of Hardy Herbaceous Perennials should be found in every garden. As cut flowers they are as desirable as Annuals, and once planted require but very little attention. A selection of varieties can be made which will furnish a constant supply of the finest cut flowers from frost to frost. We are always glad to assist our customers in making the best selection for various purposes and invite correspondence. Our plants are strong and vigorous, and will bloom the first season after planting.

Prices: All Mardy Perennial Plants, except where noted, each 15c.; dozen, $\$ 1.50 ; 100, \$ 10.00$. Twenty-five plants of one variety will be furnished at the hundred rate, and six at the rate per dozen, but less than six plants of one kind will be charged at 15 cents each.

\section{SPECIAL OLD-FASHIONED GARDEN COLLECTIONS}

50 plants in variety, 4 each, our selection, $\$ 4.00$.

100 plants in variety, 5 each, our selection, $\$ 7.00$

Prices are based upon the stock carefully packed and delivered f. o. b. Bedford.

\section{General List of Herbaceous Perennials}

ACANTHUS mollis (Bear's Breech). White to purple. 3 feet. July and August. Sun.

" var. latifolius. Purple. July and August. 4 feet. Large, glossy foliage. Sun.

ACHIIrA Egyptica (Egyptian Milfoil). Pale yellow. July to October. 1 to 2 feet. Sun.

"ptamica var. "The Pearl" (Double Sneezewort) Pure white June to October. 11/2 wort) $21 \%$ feet. Profuse bloomer and excellent for cutting. Sun.

"tomentosa (Woolly-leaved Milfoil). Yellow. May to September, 8 to 10 inches. Evergreen foliage. Sun.

“ millefolium roseum (Rosy Milfoil). Pink. July. to September. 12 to 18 inches. Foliage deep green and finely cut. Sun.

ACoNrTum autumnale (Monkshood). Deep blut July to September. 3 to 4 feet. Flowers pri duced in large spikes. Sun or shade.

" Napellus (True Monkshood). Deep purple blue. July to September. 3 to 4 feet. A very free bloomer. Sun or shade.

"var. bicolor (Variegated Monkshood). Blue and white. 3 to 4 feet. July to September. Sun or shade.

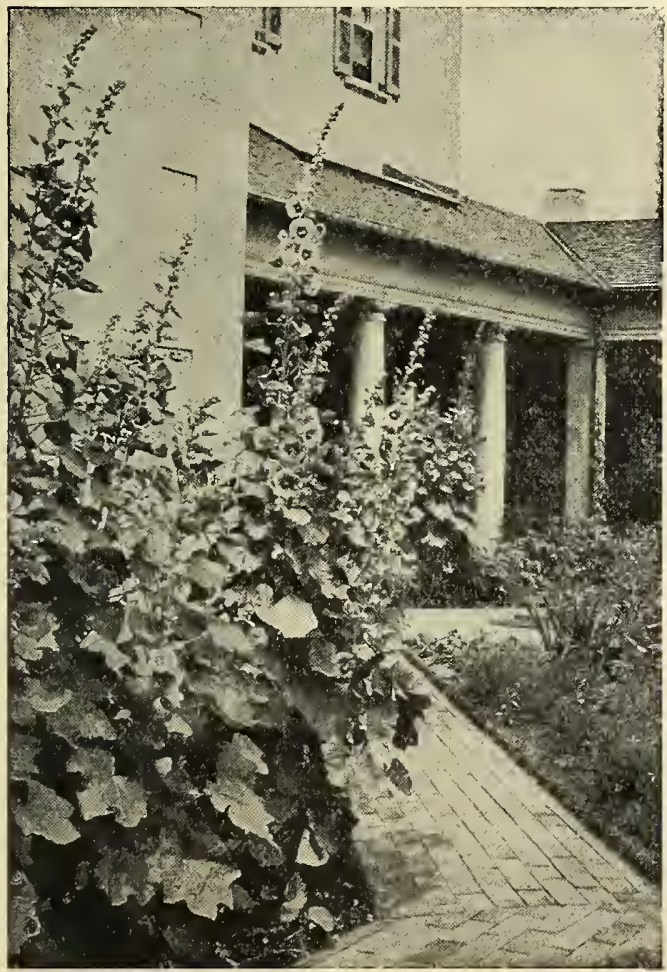

Hollyhocks-Althaea Rosea.
ACTAEA spicata (Baneberry) May and June, 3 feet. Long spikes of clear white flowers succeeded by bunches of conspicyous berries.

ADONIS vernalis (Spring Adonis). Yellow, \& to 12 inches. April to June. One of the earliest of Spring-flowering plants. Sun or half shade.

AFGOPODIUM Podograria variegata Cream white. 12 to 15 inches. May to June Sun.

AGROSTEMTMA coronaria (Dusty Miller). Crimson. 1 to 2 feet. June to July. Sun.

" var. alba. White. 1 to 2 feet. June to July. Sun.

“ Flos-Jovis (Jupiter's Flower). Crimson pink 1 to 2 feet. J'une to July. Sun.

AIRA coerulea variegata (Hair Grass). Purple. 1 to 2 feet. Sun.

AJUGA reptans (Bugle). Blue. 3 to 4 inches. May to June. Sun or shade.

ALSTROFMERIA aurantiaca (Peruvian Lily). Orange. 2 to 3 feet. July to August. A tuberous-rooted plant, requiring protection while young. Half shade.

\section{Althaea Rosea - The Hollyhocks}

Few hardy plants are more worthy of cultivation than the Hollyhocks. For interspersing among shrubbery, or planting in rows back of lower growing plants they are invaluable. Whether single or double, they appear in the most lovely shades of color. They thrive in any good soil. A slight protection in Winter is beneficial. The following strain is the most beautiful possible to secure.

Strong plants which will bloom this season: Each 15c., doz., $\$ 1.50,100 \$ 8.00$

Pure white. Double.

Canary yellow. Double.

Salmon. Double.

Carmine Pink. Double.

Red. Double.

Purple Carmine. Double.

Finest single Mixed. New England strain.

Fringed or Alleghany.

AIYSSUM saxatile compacta (Madwort). Yellow. and fragrant. 1 foot. April to June. Sun.

AMSONIA Tabernaemontana. 2 to 3 feet. Late May and early June. A tough-barked perennial herb. Flowers pale blue, in dense spikes. Good in the hardy border.

ANCruSA Italica (Alkanet). Blue. 3 to 4 feet. May to July. Sun.

ANAFHAIIS margaritacea (Everlasting). September. Pure white. 2 feet. Foliage gray. A good border plant, and useful commercially for Immortelles.

ANTHEMIS tinctoria (Golden Marguerite). Yellow. 2 to $3 \mathrm{ft}$. May to October. Flowers persistently; is good for cutting and easy of cultivation. Sun.

“ var. Kelwayi. Yellow. 2 to 3 feet. June to October. Sun.

ANTERRICUM liliastrum major (St. Bruno's Lily) White. 1 to 2 feet. May to July. Lily-like fiowers, $2 \frac{1 / 2}{\text { inches across. Requires }}$ protection. Sun. 


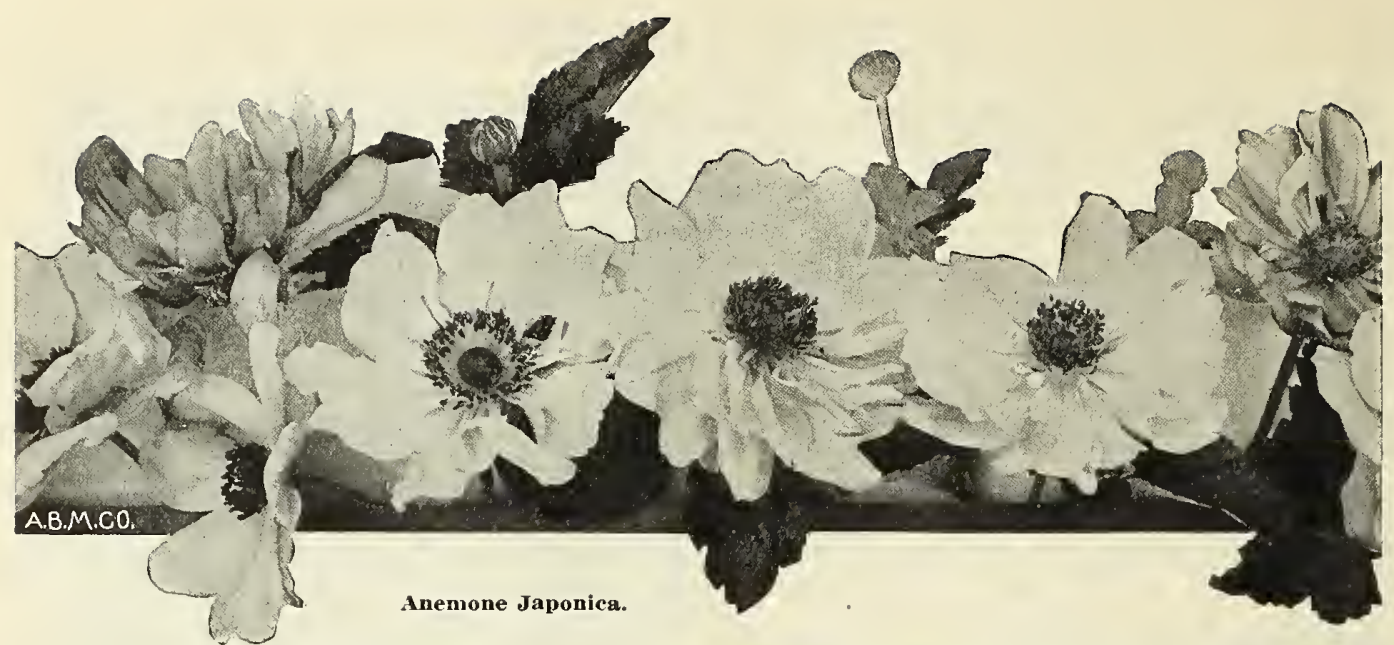

\section{The Anemones}

The Japanese Anemones should be found in every garden. They bloom very freely and produce flowers unexcelled for cutting purposes, sometimes as late as December 1st. They require good soil and protection while young.

ANEMONE Japonica (Japanese Windflower). Rose 2 to 4 feet. September to November. Sun or half shade.

" var. alba. White. 2 to 3 feet. September to November. Sun or half shade.

"var. Iady Ardilaun. Semi-double. White. 2 to 3 feet. August to October. A very robust form of the above, with large, massive folige. Sun or half shade.

" var. Prince Henry. Semi-double. Dark red. 1 to 2 feet. August and September. Flowers large and borne in profusion. Sun or hall shade.

"var. Queen Charlotte. Semi-double. Silver pink. 2 to $2 \frac{1 / 2}{2}$ feet. August to October. Blooms earlier than the preceding varieties. Flowers fully 4 inches across, last well when out Very hardy. Sun or half shade.

“Pennsylvanicum (Canada Windflower). White. 1 to 2 feet. May to July. Sun or shade.

“ Pulsatilla (Pasque Flower). Purple. 9 to 12 inches. April and May. Sun or shade.

" sylvestris (Snowdrop Anemone). White 12 to 15 inches. April and May. Sun or shade.

APIOS tuberosa (Ground Nut). 4 to 8 feet. July and August. Vigorous habit; a native climber, coming in low grounds; grows well in the wild border in any loose, rich soil; desirable for the rapid covering of unsightly places; flowers fragrant; chocolate brown.

\section{The Columbines}

AOUIIEGIA coerulea (Rocky Mountain Columbine.) Blue and White. 1 to $1 \frac{1 / 2}{2}$ feet. May to July. Sun.

"Californica hybrida (California Columbine). Various colors. 1 to 2 feet. May to July. Sun.

Canadensis (Wild Columbine). Red and yellow. 1 to 2 feet. April to June. Sun

" chrysantha (Golden-spurred Columbine). Yellow. 3 to 4 feet. May to August. Sun.

" glandulosa. Blue and white. 1 to $1 \frac{1 / 2}{2}$ feet. May and June. Sun.

" Skinneri (Mexican Columbine). Orange and red. 1 to 2 feet. May and June. Sun.

"vulgaris (European Columbine). Various colors. $11 / 2$ to 2 feet. May to July. Sun.

" var. alba (Munstead White Columbine). White 2 to 3 feet. April and May. Sun.

"var. flore pleno (Double European Columbine) various colors. 1 to $1 \frac{1 / 2}{2}$ feet. May to July. Sun.

ARABIS albida (White Rock Cress). White. 6 to 8 inches. April to June. Fragrant. A valuable plant for the border.

ARETARIA Balearica. 4 inches. Of moss-like growth and suitable for rockwork. White
ARMERIA alpinum (Alpine Thrift). Pinkish lavender. 6 to 9 inches. April to June. Sun

" cephalotes rosea (Sea Pink). 12 inches. Light pink. April to July. Sun.

“ formosa. Crimson pink. 12 inches. May to July. Sun.

" maritima (Cushion Pink). Pink. 3 to 6 inches. May and June. Sun.

"var. Tauchiana. Crimson. 3 to 6 inches. May and June. Sun.

" var. robusta. Large, crimson flowers on stems 6 to 8 inches long, produced all through the Summer. Very useful for edging and good for cutting.

ARTEMISIA abrotanum (Southernwood). White. 3 to 4 feet. Sun.

“ Dracunculus (Tarragon). White. 2 feet. Sun. rigida (Small Southernwood). 8 to 12 inches. Whitish, fern-like, fragrant foliage. Most easy of cultivation. Sun.

" Pontica (Roman Wormwood). Yellow. 1 foot. Leaves finely divided and whitish beneath.

"Stelleriana (Old Woman). Yellow. Silvery foliage and flowers in racemes. 2 feet. Sun.

ARUNDO donax (Giant Reed). Reddish. Foliage large and graceful. 10 inches. Sun.

“ var. variegata. Golden and green variegated form of the above. 10 inches. Sun.

AScripras tuberosa (Butterfly Weed). Red or-

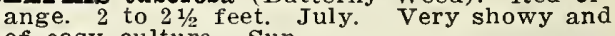
of easy culture. Sun.

"incarnata. 3 to 4 feet: Leafy and branching. Showy heads of red or purplish-red flowers in July.

ASPERUIA odorata (Sweet Woodruff). White. 12 inches. May and June. Shade.

ASPHODExUS luteng (King's Spear). Yellow. 2 to 3 feet. June and July. Sun or half shade.

\section{The Asters - Michaelmas Daisies}

The hardy Aster deserves a place in every garden, as it thrives under any condition, is graceful in habit, and blooms profusely when the scarcity of hardy flowers is most marked.

The following varieties include the choicest of all newer and older sorts.

ASTER alpinus (Alpine Aster). Violet. 3 to 10 inches. May and June. Sun or half shade.

“ var. Autumn King. Light blue, dark center. 4 feet. September.

" var. Beauty of Bedford. Purplish pink with yellow center. 3 feet. September.

“ var. Bowman. Dark blue. 3 feet. September.

var. Excelsior. Purplish pink, with dark center. 2 feet. September.

" Lady Trevellyn. White. 4 feet. August and September. Very ornamental and showy. Sun.

" Madonna. White. 3 to 4 feet. August and September. One of the best Asters in cultivation. Sun.

" var. Maiden's Blush. Purplish pink. 3 to $3 \frac{112}{2}$ feet

“ var. Ne Plus Ultra. Light purple. 3 to 4 feet. September. 
ASTERS-Continued.

ASTrR Novae-Angliae (New England Aster). Purple. 3 to 5 feet. August and September. Sun.

" var. albus. White. 3 to 4 feet. August and September. Sun.

“ var. roseus. 4 feet. A most charming variety of the above charming variety of the above crimson. The most magnificent of all hardy Asters. Each $15 \mathrm{c}$.

"var. Novae-Angliae rubra. Large red, very showy. 4 feet. Sepred, very show y. 4 c. loz. $\$ 2.50$

"Novi-Belgii (New York Aster). Blue violet. 3 to 5 feet. September and October. Sun.

"var. Iceberg. Dwarf and floriferous. White.

" var. Jumbo. Large, purple flowers, with golden center. 3 to 4 feet. September.

"var. polyphyllus. White, with yellow center. September. 4 feet.

“ var. Snowdrift. Pure white and spreading in growth. September. 1 foot.

\section{THREE NEW ASTERS}

The following three named Asters were among a number of new varieties imported by us recently. They are pronounced by all who see them to be the most beautiful sorts yet introduced.

ASTER var. Novelty. Light blue flowers with yellow center. produced in great quantity. $11 / 2$ feet. September. Each 20 c., doz. $\$ 2.00$.

"var. Pink Beauty. Blush pink, with dark center. 3 feet. September. Each 25c., doz. $\$ 2.50$.

" spectabilis var. Nenco. Deep lavender. Individual flowers 2 inches across. Undoubtedly the most beautiful Fallflowering hardy Aster in cultivation. Excellent for cutting. $21 / 2$ to 3 feet. September. Each 20c., doz. $\$ 2.00$.

ASTrIBE (See Spiraea).

AUBRFTIA deltoides (Rock Cress). Dark violet, 8 to 10 inches. April and May. Sun or half shade.

BAPTISIA Australis (False Indigo). Blue. feet. May and June. Very showy and of easy cultivation. Sun.

BEIIIS perennis (English Daisy). Pink and white. 3 to 6 inches. April to June. Flowers very double and beautiful. Sun.

BETONICA (See Stachys).

BOCConIa cordata (Plume Poppy). White. 3 to 5 feet. July and August. Good for sub-tropical effects. Sun.

BOITONIA asteroides (False Chamomile). White 4 to 5 feet. September and October. One of the best late-flowering perennials. Sun.

"latisquama. Pinkish lavender. 4 to 5 feet. July to October. Worthy of a place in every garden. Sun.

" var. nana. Pinkish lavender. 2 feet. July to September. Quite dwarf and compact in growth. Sun. New. Each 25c, doz. \$2.50.

BUPHTHATMUM galicifolium (Ox-Eye). Yellow. $1 \frac{1 / 2}{2}$ feet. June and July. Sun or half shade.

CAIIMrris incisa. Pale purple. 1 to 2 feet. July to September. Sun.

CAIIIRHOF involucrata (Poppy Mallow). Violet crimson. Trailing in habit; very showy and beautiful. 9 to 12 inches. June to September. Sun.

CARXOPTERIS Mastacanthus (Blue Spiraea) Blue. 3 feet. September to November. Sun Each 25 cents.

CAssIA Marylandica (Wild Senna). Yellow, 3 to 4 feet. July to September. Sun.

\section{Campanula - Bluebells}

The beauty of the Bluebell is well known and the plant is the most hardy and easily grown. The following list comprises the best and most freeflowering varieties.

CAMRANUIA Calycanthema (Cup and Saucer). A well-known and most beautiful variety of Campanula, flowering in July. We offer them in white, pink and blue, and in sizes to bloom the first season. Should be given light protection in Winter.

"Carpatica (Harebeli). Blue. 9 inches. June to September. Compact and neat in growth and most useful for edging. Sun.

" var. alba. White. 9 inches. June to Sept. Sun. glomerata (Clustered Bellflower). Purple. 1 to 2 feet. June and July. Sun.

" latifolia macrantha. Purple. 3 feet. May and June. Flowers very large. Sun and shade.

"media (Canterbury Bell). Biennial. $1 \frac{1 / 2}{2}$ to 4 feet high. Late June and July. Flowers blue, white, rose and striped. Corolla very large and bell-shaped; bright and attractive.

" nobilis (Noble Bellflower). White. 2 feet. June and July. Sun

"persicifolia (Peach Bells). Purple. 3 feet. June and July. Sun or shade.

" var. alba. White. $1 \frac{1}{2}$ to 3 feet. June and July. Sun.

“ var. Moerheimi. Double white. $1 \frac{1 / 2}{2}$ to 2 feet June and July. Sun.

"prramidalis (Chimney Bell). Blue. 4 to 5 feet. July and August. Requires protection-in Winter. Sun.

" rotundifolia (Blue Bells of Scotland). Blue, 1 foot. June and August. Sun.

" trachelium (Coventry Bells). Purple. 3 feet. June and July. Very hardy and one of the best. Sun. 


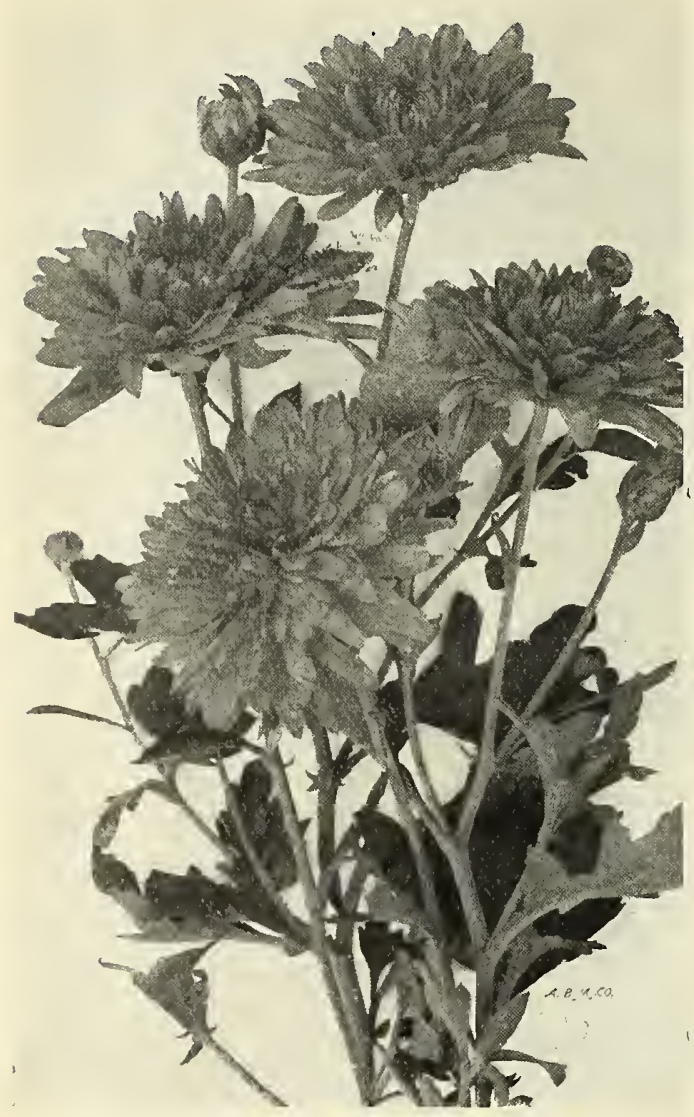

Hardy Chrysanthemums var. Charles Jenks.

CATANANCEE coerulea. Blue. 2 feet. July and August.

CENTAUREA macrocephala. Yellow. $2 \frac{1 / 2}{2}$ to 3 feet. July and September. Good for cutting. Sun.

“ montana. Purple. 12 to 20 inches. September. var. alba. White. 9 to 15 inches. May to J'uly. Sun.

CENTRANTHUS ruber (Valerian). Crimson. 2 feet. June to August. A beautiful hardy plant.

var. alba. White. 1 to 3 feet. June to August Sun. Each $25 \mathrm{c}$.

CERASTIUM Boissierii (Mouse Ear). White, 10 to 12 inches. June, Silvery foliage. A good border plant. Sun or half shade.

tomentosum. White. 3 to 6 inches. June. Useful for covering dry spots or banks. Sun.

CHELONE Jyoni (Turtle Head). Red. 2 to $2 \frac{1}{2}$ feet. August. A most useful and handsome plant. Sun or half shade.

" obliqua alba. White.

\section{The Daisies}

CHRYSANTHFMUM leucanthemum hybridum (Shasta Daisy). A variety remarkable for its prolific flowering qualities, as it can be relied upon to bloom constantly from June until frost. It thrives under severe conditions, and the flowers, which frequently measure 4 inches in diameter, are unexcelled for cutting. White. 1 to 2 feet. Sun.

" var. Alaska. White. 1 foot. June. Sun. "var. Californica. Yellow. 1 foot. June. Sun. " Maximum. White. 1 foot. July. Sun.

" var. King Idward. White. $1 \frac{1}{2}$ feet. July. Sun.
New Giant Hardy Chrysanthemums

The following two varieties are exceptional, both in height of plant and size of bloom. They were brought from England three years ago, and have since been grown in a garden near Boston without the slightest protection. If they were treated with disbudding as are tender Chrysanthemums, their blooms would undoubtedly fully equal such in size. We confidently recommend these varieties as the best hardy sorts yet introduced.

CHRYSANTHEMUM Pavona. Height $4 \frac{1 / 2}{2}$ feet. Flowers pinkish lavender. 3 inches across. Each 50 cents.

"Orient. Height 5 feet. Flowers pure white. $31 / 2$ inches across. Early. Each $50 \mathrm{c}$.

\section{HARDY CHRYSANTHEMUMS}

The hardy Chrysanthemum is very deservedly coming more and more into favor as a garden plant. Being very free flowering, excellent for cutting, and one of the last to disappear in late Autumn, it should be more generally grown. While it is quite hardy, a slight Winter protection is advisable. The following named varieties have been selected from a large number of prize winners.

CHRYSANTHIMUM aurea floribunda. Yellow, 18 inches. October.

" Bridesmaid. Blush. 2 to 3 feet. October.

Charles Jenks. Pure white, fading to light pink. Very early, of medium height, and free flowering. Size of flowers, $1 \frac{1}{2}$ inches.

"Davidiana. Pink. 2 to 3 feet. October.

"Goldfinch. Golden. 2 to 3 feet. October.

"Golden Pheasant. Golden 2 to 3 feet October.

"Julia Iagravere. Dark red. 2 feet. October.

Soliel d'or. Orange. 2 to 3 feet. October.

"Tiber. Red. 2 to 3 feet. October.

"Victor. Crimson. 2 to 3 feet. October.

"White Swan. White. 2 to 3 feet. October.

"Yellow Queen. Yellow. 2 to 3 feet. October.

BUTTON or SMALL-FLOWERING POMPON CHRYSANTHEMUMS

These varieties are very decorative. The charming little double flowers are the last to succumb to Winter, frequently blooming after quite severe frost.

Little Bob. Brownish crimson. Each $25 \mathrm{c}$. Mignon. Sulphur yellow. Each 25c.

CTMICIFUGA racemosa (Snakeroot). White. to 8 feet. July and August. Sun or shade.

CrEMaTrS Davidiana. Blue. 2 to 3 feet. August and September. Flowers delicately scented. Good for border. Sun.

“ recta. White. 3 feet. June and July. A great bloomer. Frangrant. Sun. Each $25 \mathrm{c}$.

CONVAIIARIA majalis (Lily of the Valley). White. 9 inches. May and June. Shade or half shade. Clumps, each $35 \mathrm{c}$., doz. $\$ 4.00$.

COREOPSIS lanceolata grandiflora. Yellow. An easily grown plant, and probably the most continuous blooming perennial known. 2 feet. June to September. Sun.

“ rosea (Pink Tickseed). Daisy-like flowers with yellow centers and rose-colored rays, about 2-3 inch across. Height about 1 foot. A valuable border plant. June to September.

" verticillata, or tenuifolia (Whorled Tickseed). A most beautiful border plant. Flowers golden yellow and about one-half inch across. Foliage feathery and dark. Height 1 to $1 \frac{1 / 2}{2}$ feet. July and August.

\section{Delphinium - Larkspurs}

The Larkspur, one of the oldest plants in cultivation, is still considered indispensable for the hardy garden It will bloom continuously if cut back when the flowers begin to fade.

DEIPHINTUM Belladonna. Sky blue. 1 foot. June to October. Sun. Each 20c., doz. $\$ 2.00$ "Chinensis grandifiora (Chinese Larkspur). Blue. 2 feet. July to September. Sun.

" var. alba. White. 2 feet. July to September. Sun.

" var. elatum. Violet-blue flowers. 3 to 5 feet June to September. Flowers in long and heavy spikes. Sun or half shade. 
DELPHINIUM-Continued.

var. coelestinum. Light blue. 2 to 3 feet. June and July. Sun or half shade.

"Gold Medal Hybrids. Flowers all shades of blue, both double and single. 3 to 4 feet. June and July. Sun or half shade.

\section{CHOICE NEW DOUBLE OR SEMI-DOUBLE VARIETIES}

The following named Hybrid Larkspurs al'e, without question, the most beautiful sorts obtainable.

DEIPFINIUM Amphytrion. Half double, center lilac violet, veined gentian blue, outer petals gentian blue. Each $25 \mathrm{c}$.

" Carnegie. Half double; enormous flower; lilac, veined sky blue, Each $25 \mathrm{c}$.

" Fans Dekking. Half double; center violet; outer petals gentian blue. Each $25 \mathrm{c}$.

" Fyacinth. Very strong; pale sky blue. Large reflexed petals as from a Hyacinth. Each $25 \mathrm{c}$

“ Ie Danube. Double; pale sky blue; center lilac pink. Each $50 \mathrm{c}$.

Iorenzo de Medici. Double; lilac pink. One of the finest varieties. Each $\$ 1.00$.

"Matin. Dwarf. Dark blue. Each $25 \mathrm{c}$

" Miss violet Geslin. Half double; outer petals blue; center lilac; very large flowers. Each $25 \mathrm{c}$.

" Moerheimi. A white-flowering Persimmon, perpetual flowering. The best of the white varipetual flowering.

"Mrs. Creighton. Double; center dark violet blue, outside gentian blue. Fach $25 \mathrm{c}$.

" Ietty. New. Half double; sky blue, veined pink, dark center. Each $50 \mathrm{c}$.

"6 Primroge. Double cream. Each 50 c

"The Reverend Irascelles. Double blue and white center. Very striking color. Each $\$ 1.00$

\section{Dianthus - Hardy Garden Pinks}

The following list comprises the best of the old hardy garden varieties, together with some of the newer and greatly improved forms of the double pinks. No garden is complete without its bed of Dianthus, and we offer a collection of the best varieties obtainable.

DIARTruS barbatus (Sweet William). In separate colors of pink, crimson, white, pink and white, or mixed, 1 to $1 \frac{1 / 2}{2}$ feet. July. Sun.

"deltoides (Maiden Pink). Deep pink. 6 to 9 inches. May and June. Sun.

" plumarius (Grass Pink). Pink. 1 foot. May and June Fragrant flowers with fringed petals. Sun.

" var. semperflorens (Homestead Pink). Pink. 1 foot. May to August. Very fragrant and free-flowering. Sun.

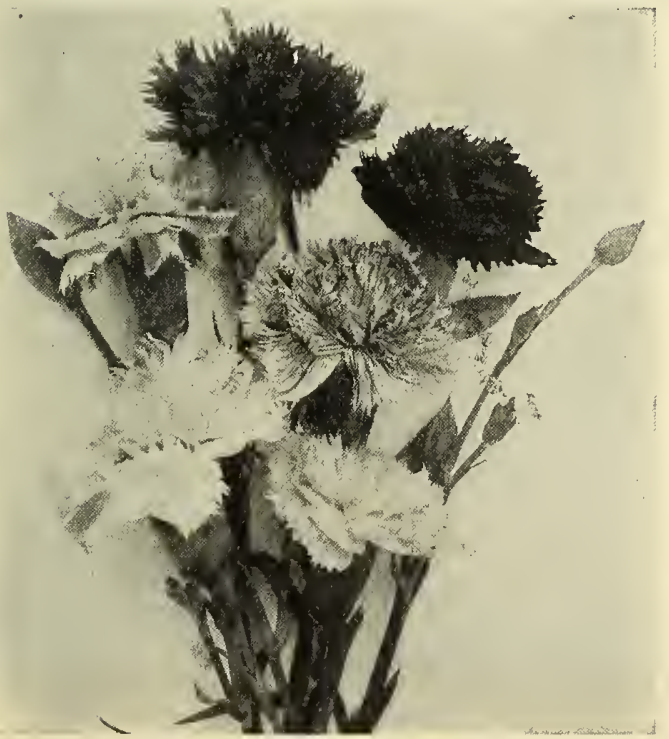

Dianthus-Hardy Pinks.

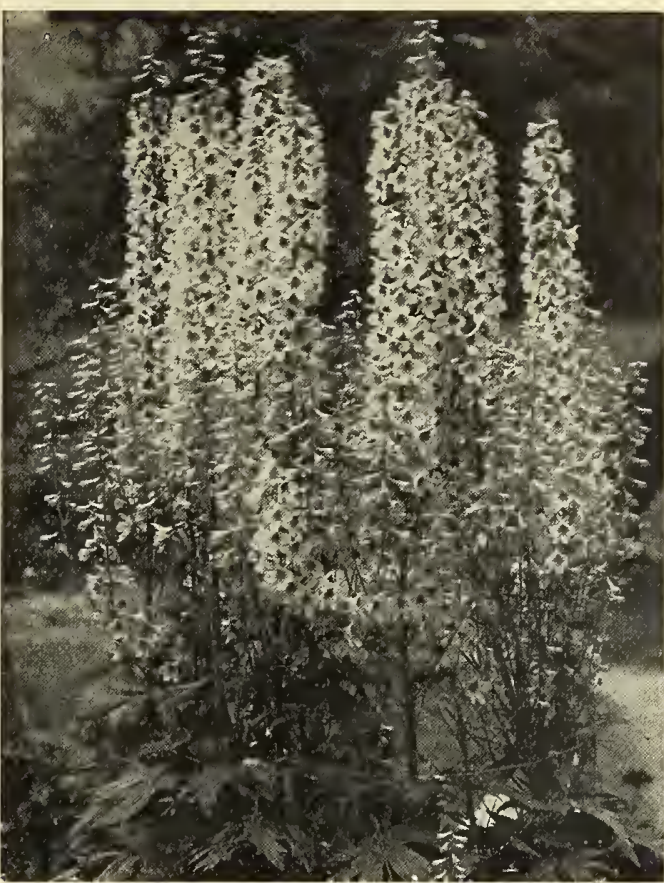

Delphinium var. Gold Medal Hybrids.

Abbotsford. Crimson. 1 foot. May and June. New and very fine Sun.

Essex Witch. Pink. 1 foot. May and June Double and free flowering. Sun.

" Her Majesty. White. Very large and double. Very fragrant. 1 foot. May to August. Sun. Eomer. Rosy red. Double and fragrant. 1 foot. May and June. Sun.

" Juliette, White and crimson. 1 foot, May to August. Very double and sweet. New and one of the best. Each $25 \mathrm{c}$, doz. $\$ 2.50$.

Iouise II. Alcott. Deep pink, extra large, with long stems. The best hardy Carnation-like Pink. $11 / 2$ feet. Sun. Each 25c., doz. $\$ 2.50$.

"New Iround. Pink. 1 foot. May to August. Very constant and sweet. Sun.

Perpetual Snow. White. 1 foot. May and June Double and very large. Flowers are delicately scented and the stems strong. It blooms constantly and freely, and is positively the best hardy white Pink in cultivation.

"Souvenir de Sale. Soft pink 1 foot. May and June. Flowers large and fragrant.

"White Reserve. White. 6 to 9 inches. May to October. A profuse bloomer and worthy of a place in every collection. Very sweet.

\section{NEW HARDY PINKS OF EXCEPTIONAL}

\section{VALUE}

DIANTEUS Mrs. True. This variety is very free flowering. Individual flowers about $11 / 2$ inche across, semi-double and pure white with greenish yellow center. A most unusual and striking variety. Fach $50 \mathrm{c}$.

" Ilizabeth Peters. This new Garden Pink is exceptionally beautiful. It is very free flowering and of the most lovely strawberry pink. tinted with orange. Center crimson. Flowers single and $1 \frac{1}{2}$ inches across. A most valuable addition. Fach $50 \mathrm{c}$

The following three varieties are semi-double, very sweet scented, and flower profusely till frost.

DIANTEUS var, Garden Queen. White, with crimson center. Semi-double, ever-blooming and sweet scented. Each 25c., doz., \$2.50.

" var. Innocence. White, with light pink center Semi-double and ever-blooming. Very sweet each 25 c., doz. $\$ 2.50$

"var. Ruby ring. Semi-double and ever-blooming. Very sweet scented. Dark red with crimson center. Like the two preceding varieties, this is an excellent border plant and should be found in every garden. Each $? 5 \mathrm{c}$, doz. $\$ 2.50$ 
DICENTRA eximia. 1 to 2 feet. Rose-colored flowers; foliage fern-like. Flowers all Summer. Rock garden and mixed border.

" spectabilis (Bleeding Heart). Crimson and white. 2 feet. April to July. A well-known and valuable plant. Half shade. Each 25c., doz. $\$ 2.50$

DICTAMNUS fraxinella (Gas Plant). Red. 2 to 3 feet. May and June. Very showy and useful for cutting. Sun or half shade.

" var. alba. White. 2 to 3 feet. May and June. Sun or half shade.

\section{Digitalis - The Foxgloves}

DIGITAIIS grandiflora. Yellow. 2 to 3 , feet. June and July. Sun or half shade.

" purpurea (Foxglove). Purple. 2 to 3 feet. June to July. Sun or half shade.

“ var. gloxiniaeflora. White to pink. 2 to 3 feet. June and July. Sun or half shade.

"var. alba. White. 2 to 3 feet. June and July. Sun or half shade.

DODECATHEON MTeadia (Shooting Star). Purplish. 9 to 18 inches. May and June. Sun or half shade.

DORONICUM excelsum (Leopard's Bane). Orange. $1 \frac{1 / 2}{2}$ to 4 feet. June.

ECHINACEA purpurea (Cone Flower). Reddish purple. 2 to 4 feet. August and September. Sun.

ECHINOPS ritro (Globe Thistle), Steel blue, 2 to 3 feet. July and August. Sun.

EPIIOBIUM angustifolia (Great Willow Herb). Magenta. 3 to 5 feet. June to August. Half Shade.

EFIMEDIUM alpinum (Bishop's Hat). Red. 9 inches. May. Half shade.

EREMURUS robustus. Peach color. 6 to 9 feet. June and July. A very rare and interesting plant. It requires rich and well-drained soil and must be protected during the Winter. Sun. Each $\$ 1.00$.

ERIANTHUS ravennae (Ravenna Grass). 6 feet. August. A stately, hardy grass, very ornamental; the foliage forms graceful clumps, from which arise handsome purplish plumes; sunny situations preferable.

IRIGERON Coulteri (Fleabane). White. 1 to $1 \frac{1 / 2}{2}$ feet. June. Sun. speciosus (Showy Fleabane). Purple lilac. 11/2 to 2 feet. June and July. Sun.

ERYNGIUM amethystinum (Sea Holly). Blue. 1 to 3 feet. June to September. Sun. A most handsome and hardy plant.

" aquaticum (Button Snake Root). White. 2 to 6 feet. June to October. Rare and useful for sub-tropical effects. Sun.

EULAIIA (Hardy Pampas Grass). Require slight protection in Winter.

"gracillima. Plume. 5 to 9 feet. Leaves narrow and dark green.

" Japonica. Plume. 4 to 5 feet. Foliage deep green and graceful. Flower panicles brownish violet Each $20 \mathrm{c}$, doz $\$ 2.00$.

"var. variegata. Plume. 4 to 5 feet. October. Sun. Each 20c.

“var. zebrina. Plume. 4 to 5 feet. October. Bars of yellow running crosswise of the leaves. Each $20 \mathrm{c}$, doz. $\$ 2.00$.

FUPATORIUM ageratoldes (White Snake Root). White. 3 to 5 feet. August and September.

" purpureum (Joe-Pye, or Trumpet Weed). Purple pink. 5 to 7 feet. July to September. Sun or half shade.

EUPHORBIA corollata (Spurge). White. 11/2 to 2 feet. August. Sun.

FESTUCA glauca (Fescue Grass). 12 inches. June. one of the most handsome and hardy edging plants in existence. Foliage grass-like, glaucous blue, tufted and evergreen.

FUNKIA Fortunei (Plantain Lily). Fale lilac. 1 to 2 fcet. July Half shade.

" Lancifolia. Pale lilac. 1 to 2 feet. July to September. Flowers in spikes. Half shade.

" subcordata grandiflora (White Day Lily). White. 1 to 2 feet. August and September. Half shade. Each 25c., doz. $\$ 2.50$

" undulata variegata. Lilac. 9 to 12 inches. August. Foliage white, green variegated. Sun.
GAIILARDIA grandiflora (Blanket Flower). Crimson orange. 2 feet. June to November. Flowers very large and good for cutting. Sun.

GENTIANA Andrewsii (Blind Gentian). Blue. feet. August and September. Dislikes dry soil. Half shade. Each $25 \mathrm{c}$.

GERANIUM atrosanguineum (Red Crane's Bill). Crimson. 2 feet. May to July. Half shade. " maculatum (Wild Crane's Bill). Lavender. 11/2 feet. May to July. Very showy. Half shade.

GIIIFNIA trifoliata (Bowman's Root). White. feet. July. Half shade. Each $25 \mathrm{c}$., doz. $\$ 2.50$.

GYPSOPHILA paniculata (Baby's Breath). White. 2 feet. July and August. One of the best cut flowers cultivated and very hardy. Sun. (Creeping Chalk Plant). Pale pink. 6 feet. June and July. Trailing in habit and good for edging. Sun

Steveni (Stevens' Chalk Plant). White. 1 to 2 feet. June and July. Somewhat dwarfer than the paniculata, but earlier and individual flowers larger. Sun.

HELFNIUM (Sneezewort). These are among the most valuable of the Fall-flowering perennials. They are all very hardy and useful, not only with other herbaceous plants, but excellent to plant among shrubs to give flower effect in late Autumn

autumnale var rubrum 4 to 5 feet September and October. A new and beautiful variety. Flowers Aster-shaped and reddishbrown. A profuse bloomer. Each 20c., doz. $\$ 2.00$.

“ autumnale superbum. Yellow. 5 to 6 feet September. One of the most magnificent Fall flowering perennials. Very hardy and good for cutting. Sun.

Bigelowii. Yellow. 2 to 3 feet. July and August. Flowers 2 inches across and good for cutting. A profuse bloomer. Sun.

"grandicephalum striatum. Orange. 3 to 4 feet. August. Sun.

" Hoopesii. Yellow. 1 to 3 feet. May and June. Earliest and very showy.

FELIANTHEMUM angustifolium (Sun Rose) Yellow. 9 inches. July and August. Evergreen and trailing. Always attractive. Sun.

“ vulgare var. citrinum. Yellow. 6 inches. June to August. Sun.

“ vulgare var. hyssopifolium. Copper. 8 to 15 inches. June to August. Sun.

HFLIOPSIS laevis (Ox-Eye). Orange. 5 feet. June to October

var. Pitcheriana (False Sunflower). Yellow. to 3 feet. July to September. Sun.

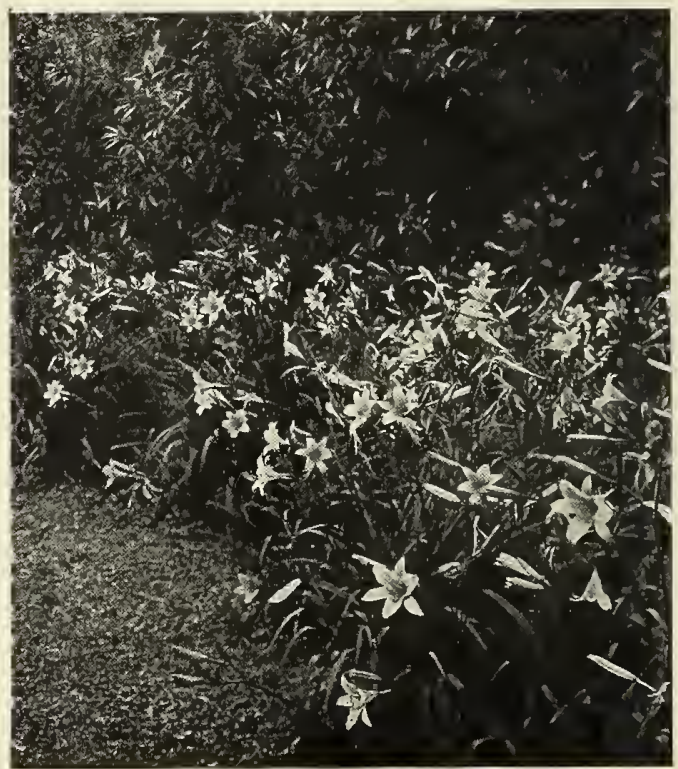

Hemerocallis Thunbergii. 


\section{The Hardy Sunflowers}

Helianthus decapetalus (Sunflower). Yellow. 5 feet. September to October. Free flowering.

“ giganteus. Yellow. 5 to 10 feet. September to October. Sun.

" laetiflorus. Yeliow. 4 to 8 feet. August and September. Semi-double, and good for cutting. Sun.

“ Miss inelligh. Very large, semi-double flowers of fine form and bright orange yellow, freely of fine form and bright orange yellow, freely
produced. 6 feet. New. Each $20 \mathrm{c}$, doz. $\$ 2.00$. " mollis (Hardy Sunflower). Yellow. 5 feet. August and september. Foliage heavy and velvety. A profuse flowerer. Sun.

" multiflorus fi. pl. Yellow. 4 feet. August and September. Valuable for cutting, but requires protection in Winter. Sun.

" tuberosa (Jerusalem Artichoke). Yellow. 3 to 4 feet. September. Effective in shrubbery. Tubers edible. Sun.

HEIIEBORUS nigra major (Christmas Rose) White. 6 to 18 inches. March and April. Should be grown in coldframe, where it will bloom in December and January. Each 30c., doz. $\$ 3.00$.

HEMFROCAIIIS aurantiaca major (Homestead Lily). Orange. $2 \frac{1 / 2}{2}$ to 3 feet. July and August. Half shade. Each $35 \mathrm{c}$

" flava (Yellow Day Lily). Orange. 3 feet. May and June. Half shade.

"fulva (Tawny Day Lily). Orange 2 to 3 feet. July and August. Half shade. Handsome foliage and showy flowers.

" var. flore pleno. Yellow. 2 to 3 feet. July and August. Half shade.

“ graminea. Yellow. 2 to 3 feet. July and August. Half shade. Fragrant and good for cutting.

"Gold Dust. Golden. 2 to 3 feet. July and August. Flowers large and fine. Half shade.

“ Middendorfiana. Golden Yellow. $11 \frac{1}{2}$ to 2 feet. June and July. Half shade. Very distinct and choice.

Orangeman Orange 2 to 3 feet. July and Aug. Half shade. Flowers large and showy.

“Thunbergii. Bright yellow. 3 feet. July to September. If cut back will bloom throughout the Summer. Half shade.

FrPATICA angulosa. Sky blue. 4 to 6 inches. May. Shade.

" triloba. Blue. 4 to 6 inches. May. Shade.

FISPERIS matronalis (Rocket). Purple. 1 to 3 feet. June and July. Fragrant flowers in spikes. One of the oldest of garden flowers. Thrives anywhere. Half shade.

HEUCFERA sanguinea (Coral Bells). Crimson. 1 to $1 \frac{1 / 2}{2}$ feet. June to September. Sun or half shade. A profuse bloomer. Good for cutting.

“ var. alba (White Coral Bells). White. 1 to $1 \frac{1 \%}{2}$ feet. June and July. Half shade.

"var rosea. Pink. 1 to $1 \frac{1 / 2}{2}$ feet. June and July. New and valuable for the garden. Half shade Each 30 c., doz. $\$ 3.00$.

FIBISCUS Mallow Marvels. An extremely handsome type of Mallows, attaining a height of 5 to 6 feet, and producing an abundance of flowers from 6 to 7 inches across, and of the richest shades of pink, crimson, white and yellow. Good among shrubbery or in the border. Will thrive in any soil, but should be given a slight mulch in Winter. August and September. Wach $30 \mathrm{c}$., doz. $\$ 3.00$.

"Moscheutos (Mallow). Rosy red. 4 to 5 feet August. Very decorative. Sun.

"var. "Crimson Eye." White. 4 to 5 feet. August Should be found in every garden. Sun.

EIERACIUM aurantiacum. Orange red. 1 foot. Very showy. June to October. Sun.

HOIIYHOCKS. (See Althaea Rosea).

FYSSOPU'S offlcinalis (Hyssop). 1 to 2 feet June to August. Aromatic shrub of culinary and medicinal value. Flowers insignificant bluish purple or white in leafy spikes. Good for edging. Can be trimmed like Box.

IBIRIS corifolia. 9 inches. May and $J$ une. The finest of the Evergreen Candytufts. producing globular umbels of pure white flowers in Spring. Useful for cutting.

“ sempervirens (Candytuft). Pure white. May and June. 6 to 8 inches. One of the best plants for edging. Very hardy. Sun.

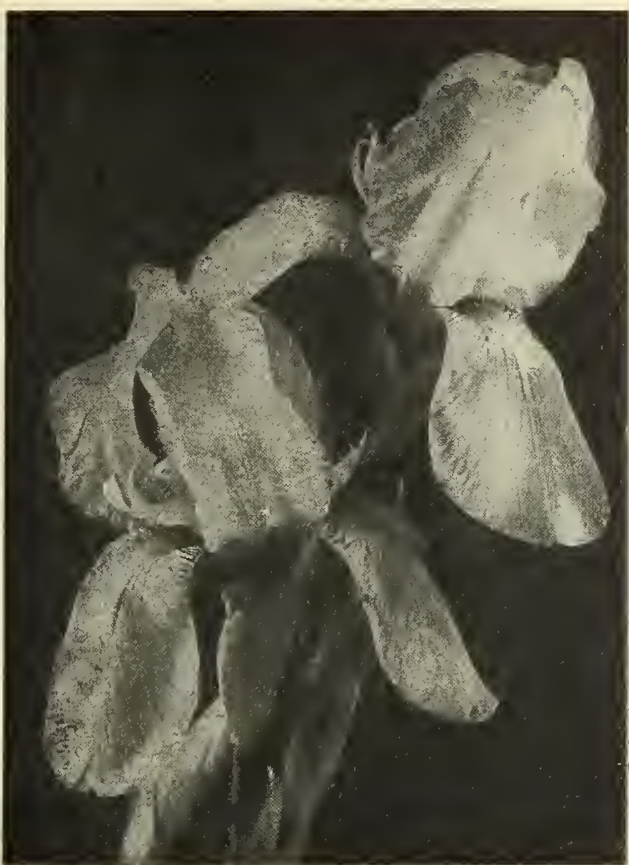

German Iris, Pallida Dalmatiea.

\section{Iris}

Iris Germanica, or German Iris

The German Iris blooms in June and is one of the most desirable Spring-flowering plants. No garden should be without a collection. We offer below a number of the best and most profuse flowering varieties.

Prices, except where otherwise noted: Each $20 \mathrm{c}$, doz. $\$ 2.00,100 \$ 12.00$.

In the following descriptions " $\mathrm{S}$ " signifies the standards, or erect petals; "F," the falls, or drooping petals.

Asiatica. "S." Purple plume. "F." Darker purple. Canary Bird. "S." Canary yellow. "F." Crimson purple.

Celeste. Pure celestial blue, changing to porcelain.

Darius. "S." Lemon. "F." Yellow, veined and corded with purple.

Donna Maria. "S." Azure. "F." Purple.

Duchesse de Nemours. "S." Pale lilac. "F." Purple violet, veined white.

Flavescens. Light primrose yellow, large flowers. Florentina alba. "S." and "F." light porcelain blue, changing to "white. "

Florentina Blue. "S." and "F." Yale blue. Fragrant.

Fector. Yellow and brownish red.

Fonorabilis. "S." Indian yellow, "F." Chestnut red.

Ia Tendre. "S." Lavender blue. "F." Blue, veined violet.

I'Innocence. Pure white, penciled purple and orange.

Madam Chereau. "S." and "F." Pure white, penciled violet.

Maori King. "S." Golden yellow. "F." Chocolate, veined white. "S." French white. "F." White, H. Darwin.
veined purple.

Pallida Dalmatica. 3 to 4 feet. Lavender, stately spikes. New and very fine. Each $25 \mathrm{c}$., doz $\$ 2.50$.

Pallida speciosa. "S." Violet blue. "F." Purplo. Each 25c.

Princess of wales. Combination violet purple, violet and yellow.

Purple Queen. "S." and "F." rich violet purple. Queen of May. "S." and "F." bright rosy lavender Silver King. "S." and "F." pure white; very large. Fragrant. 


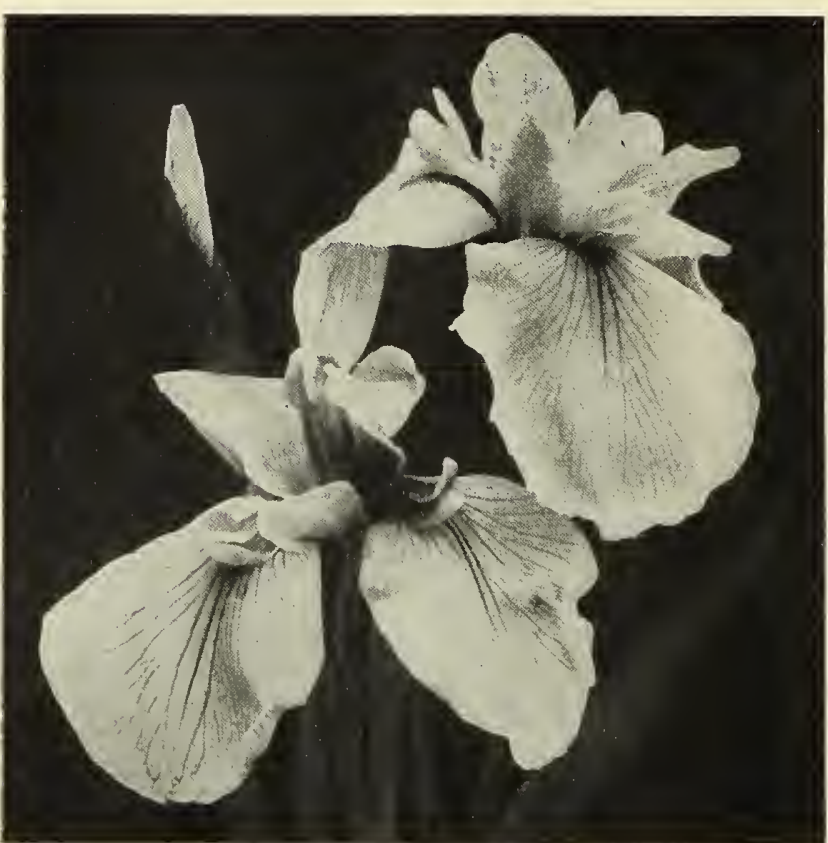

Iris var. Snow Queen.

IRIS-Continned.

\section{Iris Kaempferi (Japanese Iris)}

The flowers of the Japanese Iris are often 8 to 10 inches in diameter and of remarkably varied and beautiful colors. They thrive best in a rich and somewhat moist soil. The blooming season is from the middle of June to about August ist. We describe here a number of the best obtainable, selected from direct importations from Japan.

Large plants....Each $\$ 0.25$, doz. $\$ 2.50,100, \$ 15.00$ Mixed colors .... " 20 , “ 2.00 , " 12.00 (Order by number or name).

No. 1. Bandai-no nami. White with yellow center No. 7. Yamato-nishiki. Light purple with dark spots.

No. 12. Gosetsu-no-mai. Navy blue with dark stripe and variegated center

No. 13. Boteki-no koe. White and purple stripes and variegated center.

No. 22. Suiren. Purple with white stripes.

No. 23. Aoi-no-ue. Light navy.

No. 26. Date-dogu. Dark purple with lighter colored center.

No. 33. Aoi-gata. Jight navv with dark stripe No. 40. Shigure-momiji. Pink and white variegated.

No. 50. Ushio-no-iro. Light blue, with darker edge petals and whitish center.

No. 62. Meigetsu. White with yellow center. (Three petals).

No. 66. Izimi-gawa. White with purple stripes

No. 68. Sanowatari. White with yellow center (Six petals).

No. 70. Zama-no mori. Purple, light, with white dges and white stripe.

No. 71. Karako-asobi. Navy blue, darker at edges, with purple stripe

No. 72 Kuro-kumo. Purple with dark stripes.

No. 78. Tagoto-no-tsuki. White, with yellow center

No. 84. Banri-nohibiki. Purple, light with dark stripes.

No. 90 . Kirin-kaku. Navy, with variegated center. No. 99. Tai-hei-raku. Purple, dark with red stripes.

Mixed Colors. -These are made up from some of the best sorts, and where mass planting is required will give the greatest satisfaction.
Miscellaneous Iris

IRIS cristata. 8 inches. Early, light blue, fringed and spotted yellow. Each $20 \mathrm{c}$., doz. $\$ 2.00$.

orienalis. 3 to 4 feet. May and June. Deep Yale blue.

"var. Snow Queen. Pure white. Very free and fine. Each 25c., doz. $\$ 2.00$.

" pseudo-acorus. Yellow, shaded or-

" pumila. 6 to 9 inches. April and May. Deep purple. A charming dwarf Iris. Very free flowering. Each 20c., doz. $\$ 2.00$.

"var. cyanea. Purple, blackish tint. Very desirable and fine. Each 20 c., doz. $\$ 2.00$

"var. formosa. Deep violet blue. A most nrofuse bloomer. Each $20 \mathrm{c}$. doz. $\$ 2.00$.

" Sibirica. June. Pale blue. Very bushy, free flowering, choice.

" var. alba. Pure white

JASTONE perennis. Blue. 1 foot. July and August. Sun, or part shade.

IATHYRUS latifolius (Everlasting Pea). Red. 4 feet. July to September. A hardy and most valuable low-growing vine. Flowers keep well after being cut. Sun.

"var. albus. White. 4 feet. July to September. Sun.

IAVANDUIA vera (Lavender). Blue. 2 feet. July to September. Flowers fragrant. Sun.

IFPACHYS pinnata. Yellow. 5 feet. June to September. Sun.

IIATRIS odoratissima (Blazing Star). Purple. 3 to 4 feet. August to October. Fragrant and free blooming. Sun.

"pycnostachya. Purple 4 to 5 feet August and September. Very showy and effective in and September. Very showy and effective in

border planting.
scariosa. Purple. 3 to 4 feet. August and September. Sun.

\section{Lilium - The Lilies}

We name below only the varieties most satisfactory for garden planting, and such as can be relied upon for hardiness and free flowering. Lilies may be planted late in the Fall, or in early Spring, and should be set about 6 inches deep.

IIIIUM auratum (Gold-banded Lily). Undoubtedly one of the finest. Its large, graceful, fragrant flowers are composed of six petals of a delicately ivory-white color, thickly studded with chocolate-crimson spots, and striped through the center a golden-yellow. 3 to 5 feet. July to September. Each 20c., doz. $\$ 2.00$.

"Batemanni. Clear orange, unspotted. July to August. 3 feet. Each 20c., doz. $\$ 2.00$

" candidum (Annunciation, or Madonna Lily). This is one of the most popular of garden Lilies. The flowers are pure snow-white and very fragrant, borne on long stems. Each $20 \mathrm{c}$, doz. $\$ 2.00$

" elegans, or Thunbergiana. Deep maroon. July. 1 to $11 / 2$ feet. Each 20c., doz. $\$ 2.00$

"speciosum album (Japan Lily). Pure white. August to September. $3 \mathrm{ft}$. Each $20 \mathrm{c}$. doz. $\$ 2$

var. rubrum. White, crimson spotted. August to September. Each 20c., doz. $\$ 2.00$

" superbum. Rich yellowish red. July. Each $20 \mathrm{c}$., doz. $\$ 2.00$.

"tenuifolium (Coral Lily). Vermilion scarlet. June to July. 1 foot. Each $25 \mathrm{c}$., doz. $\$ 2.50$.

" tigrinum (Tiger Lily). Orange. July to September. 4 feet. Showy and most easy of cultivation. Each $15 \mathrm{c}$., doz. $\$ 1.50$

" var. flore pleno (Double Tiger Lily). Orange. August to September. 4 feet. Each $20 \mathrm{c}$. doz., $\$ 2.00$.

Irraria Cymbalaria (Toad Flax). Blue. 4 feet. June to September. Half shade.

IINUM favum (Flax). Yellow. 1 to 2 feet. June and July. Sun.

" perenne. Blue. $11 / 2$ feet. May to August. Sun or half shade. 
IOBEIIA cardinalis (Cardinal Flower). Scarlet. 3 feet. August and September. One of the showiest plants in cultivation. Sun or shade.

" syphilitica (Blue Cardinal Flower). Blue. 1 to 3 feet. August and September. Sun.

IUPINUS polyphylus (Lupin). Blue. 2 to 5 feet. June and July. Will bloom all Summer if cut freely. Sun.

"var. albus. White. 4 feet. June and July. Sun.

" var. roseus. Pink. 4 feet. June diñ July. Sun. Each $25 \mathrm{c}$.

IYCHNIS Chalcedonica (London Pride). Scarlet 4 feet. June to August. An old and valued plant. Sun and shade.

"dioisa fl. pl. (Red Campion). Purple red. 1 to 3 feet. May and June. One of the best border plants. Sun.

"Flos-cuculi alba. White. 18 inches. May to August. Sun.

"var. plenissima. Pink. 1 to $11 / 2$ feet. May to october. Flowers are unexcelled for cutting. Thrives in any soil. Sun. Each 20c., doz. $\$ 2.00$.

" Haageana. Red. 1 foot. June to August. Large flowers in clusters, borne in profusion. Sun and half shade.

"vespertina fl. pl. White. 2 feet. July to September. A free bloomer. Sun.

IYCHNIS viscaria splendens pleno (Ragged Robin). Red. 1 to 2 feet. June. Sun.

IYSIMACHIA clethroides. White. 2 to 3 feet. June and July. Sweet-scented flowers in dense spikes. Sun.

" nummularia (Money Wort). Yellow. 2 inches. June to October. Excellent for covering ground under shade trees or bare spots in shady places. Sun and half shade.

IYTHRUM Salicaria (Loosestrife). Purple. 2 to 3 feet. July and August. Sun.

"var. roseum superbum. Pink. 4 to 5 feet. August. Good for cutting. Thrives best in damp situations. Half shade.

MAIVA Moschata (Marsh Mallow), Pink. \& feet June to September. A profuse bloomer and very hardy. Sun or shade.

"var. alba. White. 1 to 2 feet. July to September. Sun and shade.

MELISSA officinalis variegata (Balm). White. 1 to 2 feet. July and August. Sun.

MreNTA piperita (Peppermint). Purplish. 1 to 2 feet August. Sun.

"viridis (Spearmint). Purplish. 1 to 2 feet. August. Sun.

MERTFNSIA Virginica (Lungwort). Blue. 1 to 2 feet. April and May. Sun and half shade.

MIITCFEIIA repens (Partridge Berry). Crimson. 2 to 3 inches. J'une. Half shade.

MONARDA didyma (Oswego Tea). Scarlet. feet. June to September. Sun.

"var. alba. White. 2 to 3 feet. June and July. Sun.

“ var. splendens. Crimson scarlet. 3 to 4 feet June to August. Sun.

"fistulosa (Bergamot). Rosy purple. 2 to 4 feet. August. Very effective. Sun.

Mrosotrs palustris (Forget-Me-Not). Blue. 4 to 8 inches. April to July. Shade.

OENOTHERA Missouriengis (Primrose). Yellow. 10 inches. August. A trailing plant of great beauty. Half shade.

"speciosa. White. 12 to 18 inches. August and September. A profuse bloomer and very hardy. Sun

"Youngii (Evening Primrose). Yellow. 12 inches June and August. A most useful border plant; exceedingly free. Half shade.

OPUNTIA Missouriensis (Prickly Pear). Yellow. 12 inches. August. Perfectly hardy and very effective in rockery planting. Each 20c., doz. $\$ 2.00$.

ORIGANUM vulgare (Pot Marjoram). Purplish pink. 2 feet. July. Sun.

OROBUs vernus (Butter Vetch). Bluish. 1 foot April and May. Sun.

PACHYSANDRA terminalis. White. 8 inches. May and June. A valuable evergreen plant, with glossy foliage. Sun and shade. Each 20 c., doz., $\$ 2.00,100 \$ 15.00$.

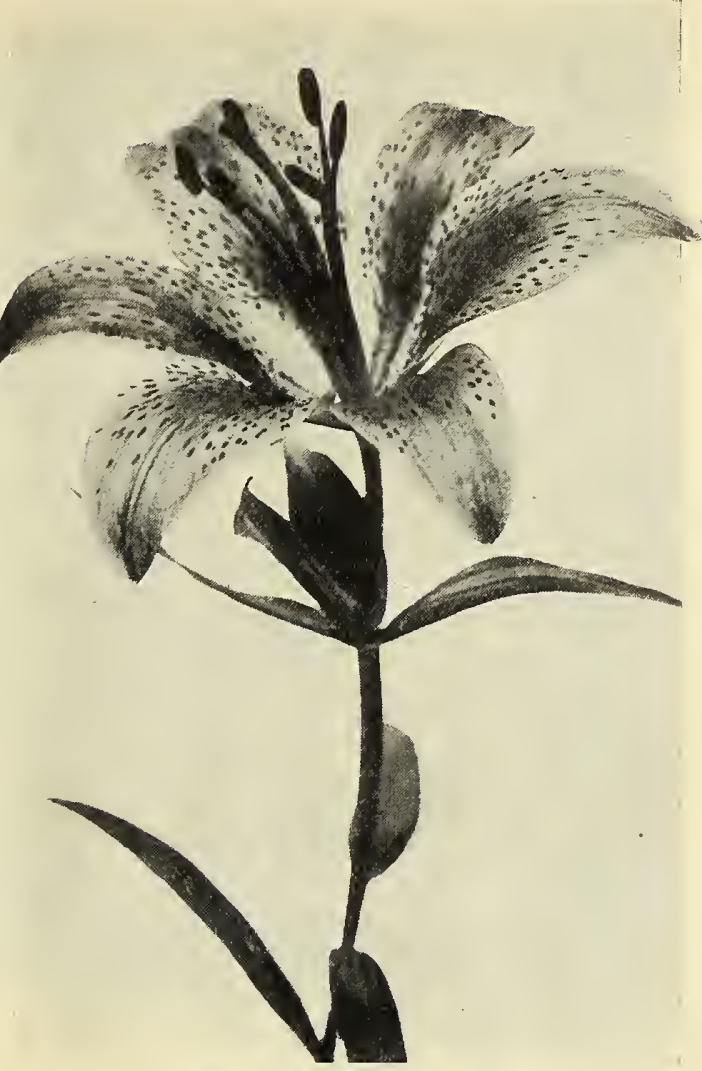

Lilinm elegans (See page 48 ).

\section{The Paeonies}

The Paeony is one of the hardiest of flowering plants; it is easily cultivated, and in beauty and usefulness is rivaled only by the Rose. The flowers are lasting and exquisitely colored. It prefers a rich, deep soil. We name a few of the most freeflowering and beautiful. We offer strong plants only. Prices, except where otherwise noted

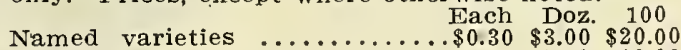
Mixed Colors .............. $2.00 \quad 12.00$

\section{DOUBLE VARIETIES}

Amabilis grandiflora. White, large, sweet scented. Petals fringed.

Baron Rothschild. Outside rose, center salmon Sweet and distinct.

Bicolor. Outside pink; center white.

Blushing Bride. Light rose, nearly white.

Buckit. Light crimson, rose scented.

Caroline Mather. Purple crimson, very dark. Extra large.

Charlemagne. Flesh white, center tinted lilac New. Each 50c., doz. $\$ 5.00$

Couronne d'or (Crown of Gold). Yellowish white, center petals with light carmine edges. Each $75 \mathrm{c}$, doz. $\$ 6.00$

Couronne de Roses. Dark rose, soft rose center

Delicatissima. Rose, large, full, sweet and very fine.

Dorchester. Cream, tinged pink. Fragrant

Duchesse de Nemours. Rose pink; large, sweet. One of the best.

Festiva alba. Pure white, with few marks of carmine in center. Each 50c., doz. $\$ 5.00$

Festiva Maxima. Resembles Festiva alba, but larger and blooms in clusters. The finest early white, Each 50c., doz. $\$ 5.00$.

Fragrantissima. Violet and rose color. Very sweet.

Francis d'ortegal. Dark purple crimson; large and sweet.

Fulgida. Very dark crimson. 


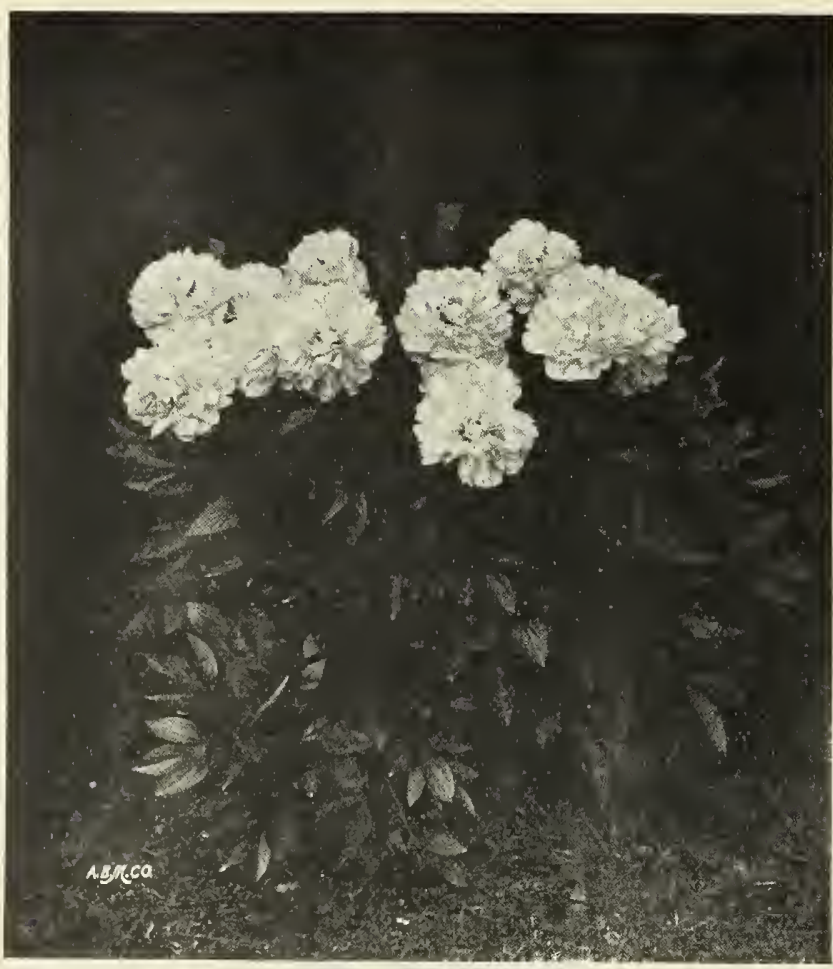

Paeony Lady Dartmouth.

PAEONIES-Continued.

Grandiflora rosea. Rose crimson.

Humei. Rose color; large, late, sweet. One of the best.

ring of Roses. Deep rose; sweet.

Iady Dartmouth. Pure white; large, Rose scented.

Ia rrance. Outside pink, yellowish center.

Iivingston (New). Pale pink; free; late. Each $\$ 1.00$.

Iouis $\operatorname{Van}$ Ioutte. Bright purple cherry; fragrant.

Marie Iemoinei. Large, white, massive flower. Late. Each $\$ 1.00$.

Modeste. Deep rose; bright. Very large.

Norfolk. Rose pink, changing to nearly white.

Officinalis alba. White, tinged red. Very early.

Officinalis rubra. Dark red. Very early.

Perfection. Outside rosy lilac, salnion center. Sweet.

Rubra superba. Dark crimson. Late. Each \$1.00.

Sweetheart. Red, white and rose center.

Tenuifolia fi. pl. Deeply cut foliage, erimson scarlet. Early. Each 75c., doz. $\$ 7.50$

Triomphe du Nord. Violet rose, shaded lilac.

zoe. Delicate rose.

\section{Paeonia Arborea}

\section{(Tree Peonies)}

The Tree Paeony is really one of the finest plants available for the garden or conservatory. It is quite hardy, and does well under the simplest treatment. It flourishes in the most astonishing manner bearing blossoms from 6 to 8 inches across, which will increase every year in beauty and size. In colors, the flowers range from white to reddish black. Each $\$ 1.00$.

\section{The Hardy Poppies}

PAPAVIR nudicaule (Iceland Poppy). Yellow. 1 foot. April to August. Blooms profusely. Sun. "var. album. White. 1 foot. April to August. Sun.

" var. miniatum. Orange. 1 foot. April to August. Sun.

\section{Oriental Poppies}

The flowers of this species are quite gorgeous and no border should be without them, as they can be grown successfuly in any soil.

PAPAVIR orientale. The common variety of Oriental Poppy. The flowers are a bright scarlet, with a black blotch at the base of each petal, and when in bloom in the Spring they make a very brilliant display.

\section{ORIENTAL HYBRIDS}

The following named varieties are among the best of the Oriental Poppies. and give a wide range of color. Prices, except where noted: Each $20 \mathrm{c}$., doz. $\$ 2.00$.

PAFAVER var. Blugh Queen. Pale pink. 2 to 3 feet. June and July. Sun.

" var. bracteatum. Deep crimson. 3 feet. May and June. Sun.

" Duke of Teck. Large, brilliant, crimson-scarlet flowers.

" var. Mahogany. Crimson maroon. 3 feet. June and July. Sun.

" var. Parkmani. Blood red. 3 feet. June and July. Sun. Each 50c., doz. $\$ 5.00$.

" var. Rembrandt. Orange salmon. June and July. Sun.

"var. Royal Scarlet. Scarlet. 3 feet. June and July. Unequaled for size and brilliancy. Each $50 \mathrm{c}$., doz. $\$ 5.00$.

"var. Salmon Queen. Soft salmon. 3 feet. June and July. Sun.

" var. Silver Queen. Silvery white, tinted pink.

PATTUS Sinengis (Blackberry Lily). Orange. $2 \frac{1}{2}$ feet. July and

P I T T T $\mathbf{I}$ M O $\mathbf{N}$ acuminatus (Beard Tongue). Lilac violet. 1 foot. July. Sun.

"barbatus Torreyi. Scarlet. 4 feet. July and August. One of the best hardy perennials in existence: will bloom constantly if cut freely. Sun.

" Dioitalis. White. 3 to 4 feet. July and August. Sun.

" grandiflorus. Lilac blue 2 to 3 feet. June and July. Sun.

" ovatus. Purple. 2 to 3 feet. May and June. Sun.

PFATARIS arundinacea variegat (Ribbon Grass). Varlegated. 2 to 4 feet Foliage white and green. Good for bordering large beds. Sun.

PFrsostrgia Virginica (False Dragon Head).

c var. alba. White. 1 to 3 feet. July and August. Sun.

PTATYCODON grandiflora (Bellflower). Blue. 1 to 3 feet. July to October. A most constant blooming plant. Sun or shade.

“ var. alba. White. 1 to 2 feet. July to October. Sun or shade.

"var Mariesil. Violet blue 1 foot July to October. A dwarf and very free flowering variety.
Sun.

AlI Hardy Perennial Plants, except where noted: Each, 15c; doz., \$1.50; hundred, \$10.00. 


\section{The Phloxes}

No hardy plants are more desirable than the Perennial Phlox. They thrive anywhere and can be planted to advantage wherever a rich color effect is desired. We mention here only a few of the new and better varieties.

Price, unless otherwise noted: Each 15c., doz. $\$ 1.50,100 \$ 10.00$.

\section{Phlox Decussata}

Aetna. Deep coral red.

Annie Cook. Flesh pink. Very fragrant. The best Phlox yet introduced.

Aurora Boreale, Orange with purple center. Large panicles.

Boule de Feu. Beautiful bright salmon, crimson eye. Very effective.

Bridesmaid. Pure white, with large crimson-carmine eye.

Coqueicot. Rich orange scarlet. One of the best and most showy.

Crepuscule. Extremely large flower, mottled blue and red.

Cross of Ironor. Striped lilac and white.

Czarina. Pure white. Early.

Eclaireur. Carmine, with rose-salmon center Dwarf in habit.

Eiffel Tower. New. One of the tallest in growth, and excellent for planting among shrubs. Flowers of immense size cherry pink, with salmon tint. Each 25c., doz., $\$ 2.50$.

Elizabeth Campbell. New. Very large spikes, light salmon, changing to pink in the center. Each 30 c., doz. $\$ 3.00$.

F. G. Von Iassburg. Fine, pure white.

Ferdinand-Cortez. Purple red.

General Chanzy. Scarlet pink, with salmon tint. Brilliant.

Gen. Van Hentz. New. Enormous flowers and trusses of the most brilliant salmon red, with white center. Each 25 c., doz., \$2.50

Gerondin. One of our best dark red varieties.

Gloire de Neuilly. Magenta crimson. Very fine.

Independence. Large, pure white flowers. Rather dwarf in habit.

Jeanne d'Arc. Pure white. Flowers extra large.

Joseph Barr. Carmine red; individual flower's, extra large.

Joseph Gerbeaux. New. Large white, with cherry-red center. Each, $25 \mathrm{c}$., doz. $\$ 2.50$.

Ia Feu de Monde. Bright salmon red. Late and fine.

Le Mahdi. Darkest of all. Deep reddish violet, with deeper eye.

Ie soliel. Bright magenta salmon. Late and fine. I'zsperance. Bright lavender pink; large, white center.

Iouis Blanc. Reddish violet, purple shadings.

Madam Iangier. Darkest red. Very fine.

Miss Stevenson. Deep pink, with conspicuous crimson eye.

Ornament. Large flowers, pink. Very large pink velvet center.

Pantheon. Bright carmine rose. Very effective.

Peach Blow. Delicate pink; deep rose center.

Richard wallace. Pure white, rosy crimson eye.

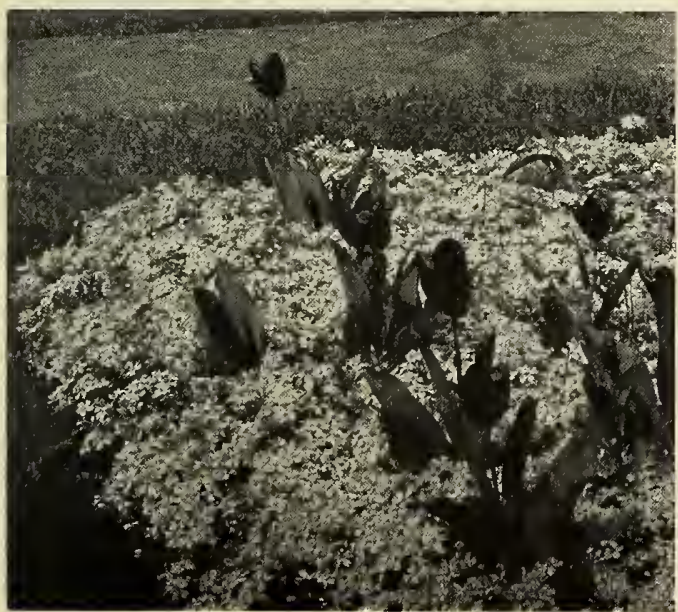

Phlox subulata (Moss Pink) and Tulips.

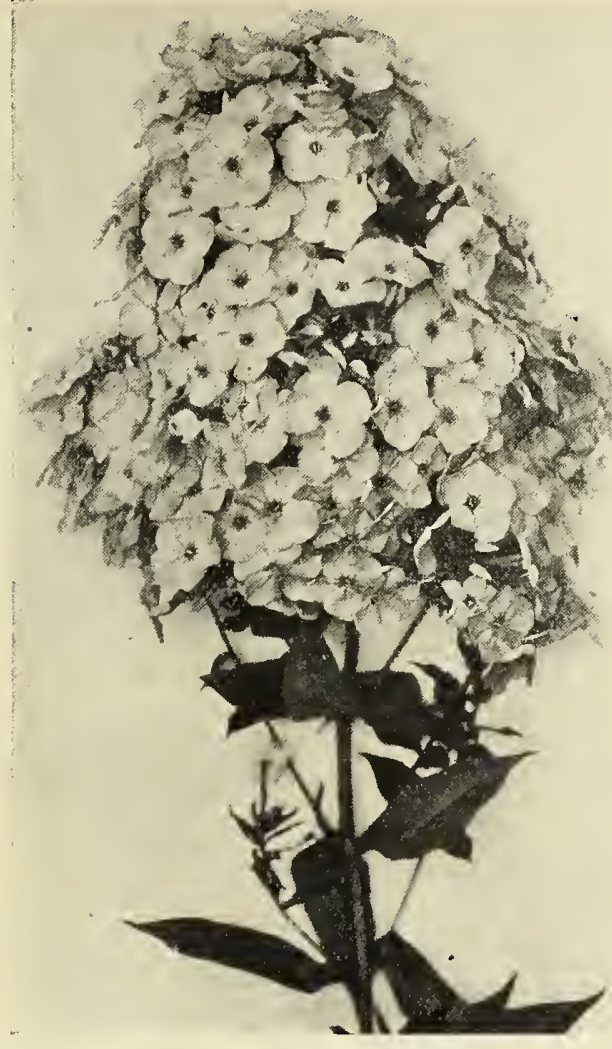

Phlox Annie Cook.

R. P. Struthers. Bright pinkish salmon, with crimson eye

Rynstroom. A gold-medal variety. New. Color bright pink, each individual flower being larger than a silver dollar. Very large trusses. Each 35c., doz. \$3.50.

Selma. Delicate pale rose, with distinct red eye

Tapis Blanc. Pure white and very dwarf. Panicles of enormous size. New: Each 30c., doz. $\$ 3.00$.

Vesuvius. Pure red, with purple eye; a dazzling color

\section{Phlox Suffruticosa \\ EARLY TALL PHLOX}

Miss I.ingard. White 2 to 3 feet. June to August. Foliage large and glossy, good for cutting. Large individual flowers. Very fine. Sun.

Indian Chief. Purple. 2 to 3 feet. June and July. Sun.

\section{DWARF PHLOX}

Phlox amoena (Hardy PhIox). Pink 4 to 6 in. April and May. Deep green leaves in tufts. Good for carpeting, border or rock garden. Sun.

"Caroliniana ovata (Mountain Phlox). Deep rose. 1 to 2 feet. June and July. Sun. Very showy and good.

"divaricata. 10 to 18 inches. May. Fragrant lilac fowers. Good for rock garden.

"stellaria (Chickweed Phlox). Pale blue. 5 to 6 inches. April and Mav. Foliage narrow and dense. A handsome plant. Sun. Each 20c., doz. $\$ 2.00$

" subulata (Moss Pink) Pink 4 to 6 inches. April and May. Foliage moss-like and deep green.

"var. alba (White Moss Pink). White. 4 to 6 inches. April and May. Very floriferous and handsome.

" var. The Bride White. 4 to 5 inches. April and May. Very fine. Pink. 1 to 3 feet. July and August. A profuse blnomer ans a most attractive garden plant. Sun. 
YIUMBAGO Iarpentae (Blue Leadwort). Blue. 6 to 12 inches. August and september. Sun.

PODOPHYIIUM peltatum (Mandrake). White. 1 to $11 / 2$ feet. May. Yellow fruit. Prefers a damp soil. Half shade. Each

POIOMONTUM coeruleum ( $\mathrm{Jac}$ ob's Ladder). Bluish purple. 1 to 3 feet. May to July. Very showy and handsome. Half shade.

" reptans (Greek Valerian) Blue 6 to 8 inches: April to June. A creeping form and very choice. Half shade

"Richardsoni (Dwarf Jacob's Ladder). Sky blue. 6 inches. June to July. Half shade.

POIYGONATUM giganteum (Solomon Seal). White 2 to 6 feet. A very useful and valuable plant.

POIYGONUM cuspidatum. A vigorous-growing plant, 6 feet in height, with large, heart-shaped foliage, and innumerable racemes of white flowers: very useful for the wild garden shrubbery, borders, or for isolated positions on the lawn, etc. Each 15c., doz. \$1.50.

" multiflorum (Mountain Fleece). Rose or white. 2 to 3 feet. September to October. Half shade.

" Baldschuanicum. White. Under some conditions a vigorous climber August. Sun. Each $50 \mathrm{c}$.

PRIMUIA officinalis (English Cowslip). Yellow. 6 to 12 inches. April and May. Half shade. Each 20 c., doz. $\$ 200$

"veris superba (Giant Primrose). Yellow. 6 to 12 inches. April and May. Very fragrant: showiest and hardiest of the Primroses. Half shade. Each 20c., doz. $\$ 2.00$.

PYRETHRUM balsamita (Chrysanthemum balsamita). Mint-Geranium, vor Costmary. Height, 2 to 3 feet. Flowers yellow, daisylike, and quite inconspicuous A very oldfashioned and much valued plant, with highly sweet scented leaves. Each $25 \mathrm{c}$.

" roseum (Feverfew). Various colors. 1 to 2 feet. June and July. Most useful and beautiful Sun.

" uliginosum (Giant Daisy). White. 4 to 5 feet, August and Sentember. Very showy and good for cutting. Sun.

\section{Double Pyrethrums}

The Double Pyrethrums are among the best of the hardy perennials. The foliage is deep green and finely cut, while the flowers, which are borne on strong stems, resemble large Chrysanthemums They thrive in any situation Price: Each $25 \mathrm{c}$., doz. $\$ 2.50$.

PYRETHRUM var. Michael Buckner. Rosy crimson

"Tront Blanc White.

“ Tre Plus Uitra. Flesh colored

" rubrum plenum. Rosy purple

RANUNCUIUS acris fl. pl. (Bachelor's Button). Yellow. 2 to 3 feet. May to September. Flowers double and good for cutting Sun

" repens (Creeping Buttercup). Yellow. 6 to 12 inches. May to August A free-flowering creeper with deeply cut foliage. Sun

RHEXIA Virginica (Meadow Beauty). Pink. 9 inches. July to september. Showy and hardy.

RUDBECKIA fulgida (Black-Eyed Susan), Orange. 1 to $2 \frac{1}{2}$ feet. August to October. Half shade.

" laciniata fl. pl. (Golden Glow), Yellow. 3 to 10 feet. July to September. Sun.

"Newmannil. Golden vellow, 3 feet. August to September. Very free flowering. Sun.

" purpurea. 2 to 3 feet. July to October. Large, handsome, crimson-purple flowers, with dark central disk.

" sub-tomentosa. $2 \frac{1}{2}$ to 5 feet. August and September. Brilliant lemon-yellow flowers, with dark purple centers

RUTA graveolens (Rue). 11/2 to 2 feet. July. Panicles of small, fragrant flowers and divided leaves. Each $25 \mathrm{c}$. doz $\$ 2.00$

All Hardy Perennial Plants, except where noted: Each, 15e; doz.., \$1.50; hundred, \$10.00.

SAIVIA pratense (Meadow Sage). Blue, 2 to 3 feet. June and July. Flowers in spikes, Sun SANGUTNARIA Canadensis (Blood Root). White. 1 foot April One of the earliest Spring flowers. Shade.

SANTOIrNA incana (Lavender Cotton). Yellow. $11 / 2$ to 2 feet. July and August. An excellent plant for effect of foliage. Sun or shade.

SAPONARIA officinalis fi. pl. (Bouncing Bet). Pink. 15 inches. April and May. Half shade

SAXIFRAGA cordifolia (Rock Foil). Pink. 15 inches. April and May. Leaves, large, deep green and heart-shaped. Half shade. Each $25 \mathrm{c}$. doz $\$ 2.50$

SCABIOSA Caucasica (Blue Bonnet). Blue. 18 inches. June and July. Sun.

SEDUM acre (Golden Moss). Yellow 2 to 4 in May and June. Good border plant. Sun.

" album (White Stonecrop). White, 4 to 6 inches. July and August. Half shade

" Ewersii var. Turkestanicum. Purplish 4 to 5 inches. September and October. Sun.

" Kamschaticum (Orange Stonecrop). Yellow. 4 to 9 inches. July and August. Showy flowers in clusters. Good for carpeting. Half shade

"Sieboldii (Siebold's Stonecrop). Pink. 6 to 9 inches. August and September. A trailing plant with glaucous foliage margined with pink, red and purple. A most beautiful plant and useful for bedding and rockwiks. Sun. "var. variegata. Variegated foliage. 6 to 9 inches. Excellent for foliage effect. Sun. 


\section{SEDUY-Continued.}

SEDUM spectabile (Showy Sedum). Pink. 18 in. August and September. One of the best plants for foliage effect, and indispensable for late blooming. Sun.

" spectabilis purpureum. (New). A form of the well known Sedum spectabilis, possessing the free flowering qualities of the type, but bloom ing from two to three weeks earlier, and with enormous heads of the deepest rose-colored flowers. Very hardy and useful. Each 20c. doz. $\$ 2.00$.

"var. stoloniferum (Purple Stonecrop). Purplish. 6 inches. July and August. Sun.

STMPER VIVUM (House Leek). Various colors. SIrENE maritima fl. pl. (Catchfly). White. 6 to 8 inches. June and July. Sun.

"Virginica (Fire Pink). Crimson. 1 to 2 feet. July. Sun.

SIIPHIUII laciniatum (Compass Plant). Yellow. July to September. Sun. Each 25c.

" perfoliatum. Yellow. 4 to 8 feet. September Sun. Each $25 \mathrm{c}$.

SISYRINCHIUM grandiflorum (Star Grass). Purple. May and June. Sun.

SOrIDAGO sempervirens (Golden Rod). Yellow. July to October.

“ July to October. 3 foet. July to October. The brightest and showiest variety of the numerous species grown.

SPIRAFA aruncus (Goat's Beard). White. 3 to 5 feet. June and July. Sun or shade.

"var. Ineiff. White. 3 to 4 feet. June. A new variety and undoubtedly the finest and

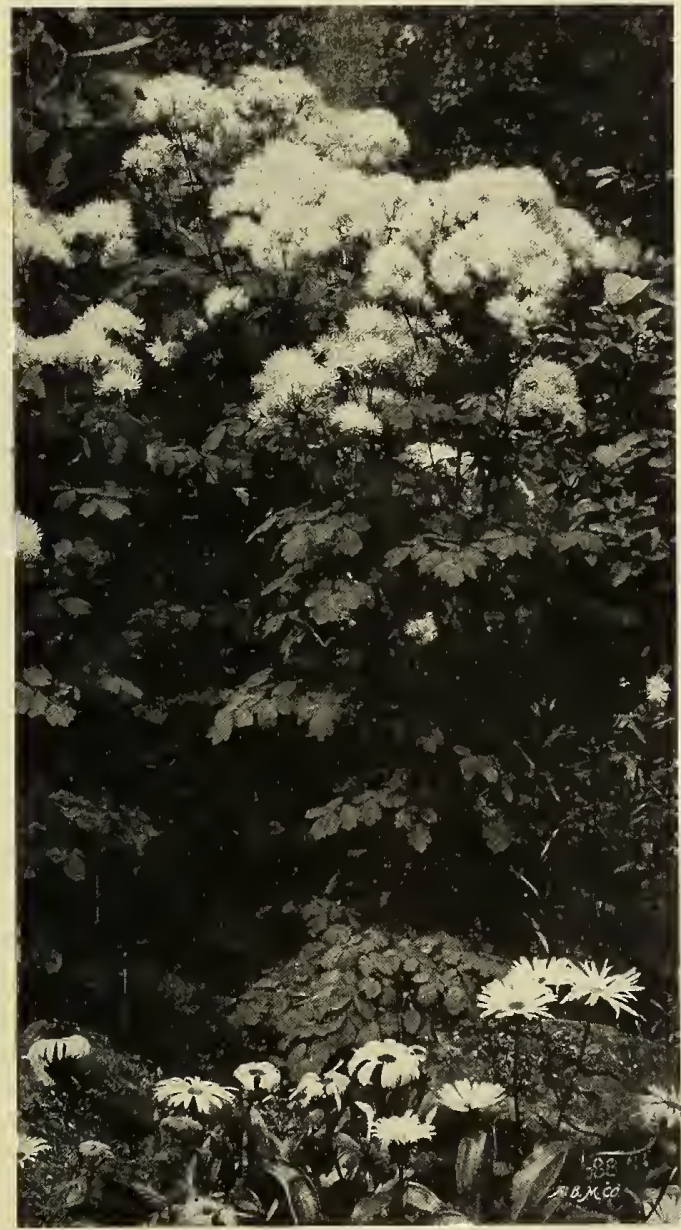

Thalictrum Aquilegifolium-Meadow Rue.

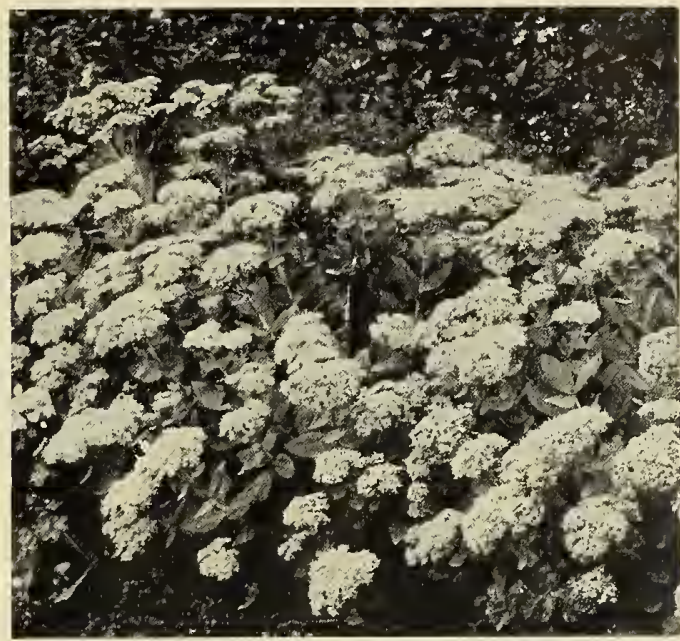

Sedum Spectabilis purpureum.

most graceful of its class. Flowers in large clusters; foliage finely cut. Sun or shade. Each $30 \mathrm{c}$., do. $\$ 3.00$

" astilboides (Meadow Sweet). White. 2 feet. June. Flowers in large, feathery plumes. One of the best. Sun or shade.

" var. floribunda. White. 2 to 3 feet. June. Most valuable for cutting, and good for forcing or oudoor culture. Sun or shade. Each 20c., doz $\$ 2.00$

"Chinensis. Pink. 2 feet. June and July. Foliage finely cut. Sun or shade. Each $20 \mathrm{c}$., doz. $\$ 2.00$.

Davidi. Rose pink. 4 to 5 feet. June and July. Sun or shade. Each 20 c., doz. $\$ 2.00$.

" filipendula fl. pl. White. 2 feet. June and July. Sun or shade. Best of all white. Each 25c., doz $\$ 2.50$

"Gladstonei. White. 2 to $21 / 2$ feet. June. Sun. Each $25 \mathrm{c}$. doz. $\$ 2.50$.

" Japonica. White 2 feet. June and July. An old and valuable variety for garden or forcing. Sun or shade.

" var. compacta multifiora. White. 15 inches. June and July.

" palmata. Carmine. 2 to 4 feet. June and July. One of the best of hardy plants. Half shade.

"Queen Alezandra. Pink. 1 to 2 feet. June to August. A new variety of great beauty, of which we can speak in the highest terms. It blooms profusely, does well on any soil, and as a cut flower is unexcelled. Sun. Each 25c. doz. $\$ 2.50$.

" venusta. Red. 4 to 5 feet. June. Sun. Each $25 \mathrm{c}$., doz. $\$ 2.50$.

STACFYS lanata (Woundwort). Purple, 1 foot. July. Sun.

STATICE latifolia (Sea Lavender). Blue. 1 to 2 feet. Julv to Sentember. Flowers in immense heads. Unexcelled as a cut flower. Sun.

STIPA pinnata (Feather Grass). 20 inches. Showy plumes; uneaualled for decoration. Sun. Each $20 \mathrm{c}$. doz. $\$ 2.00$.

STOKFSIA cjanea (Stokes' Aster). Blue. 1 foot. August to October. An excellent Autumnflowering plant. Sun.

"var alba. White 1 foot August to October. It blooms profusely and is excellent for cutting. Sun.

THAICTRUM aquilegifolium (Meadow Rue). White. 2 feet. May and June.

Delavayi. Lilac. $2 \frac{1 / 2}{2}$ to 3 feet. July and August. Sun.

THFRMOPSIS Caroliniana. Yellow. 2 to 4 feet. June and July. Sun or shade.

THYMUS Serpyllum aureus (Thyme). Jilac. 3 to 4 inches. June to August. An evergreen: golden and green foliage. Very fragrant; hardy. Sun.

"vulgaris. Lilac. 2 to 3 in June and July. Sun.

" lanuginosus. June and July. 3 to 4 inches. Creeping habit. Leaves downy and gray. Good for rockeries.

All Hardy Perennial Plants, except where noted: Each, 15c; doz., \$1.50; hundred, \$10.00. 


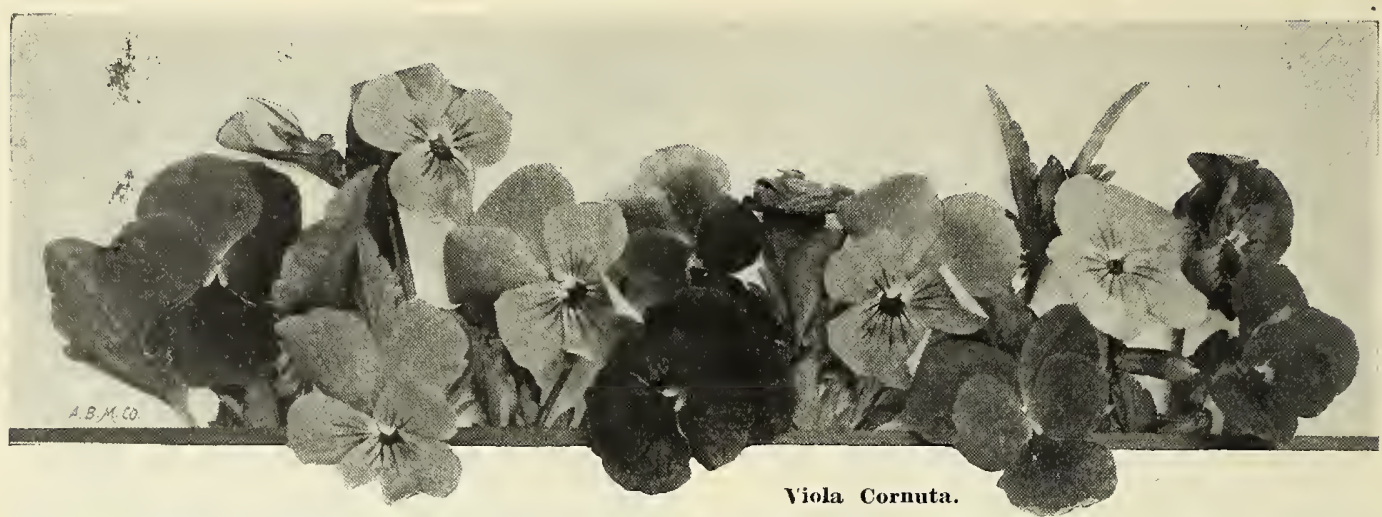

TRADISCANTIA Virginiana (Speedwort). Purple. 1 to $2 \frac{1}{2}$ feet. May to August. Sun and shade.

TRIIIIUM grandiflora (Wood Lily). White. 6 to 9 inches. May. Half shade.

TRITOMA Pfitzeri (Flame Flower). Orange scarlet. 3 to 4 -feet. August to October. Produces large spikes of flowers very showy and handsome. Sun or half shade.

" nobilis. Orange. 5 to 7 feet. August to November. Sun or half shade. One of the showiest of hardy plants. Thrives in any soil.

TROIIIUS Europeus (Globe Flower). Yellow. 18 inches. May and June. A profuse bloomer, thriving in any situation. Half shade.

" Orange Globe. Orange. 2 feet. May and June. A strong grower, producing large, globe-shaped flowers on stiong stems. Half shade. Hach $20 \mathrm{c}$, doz. $\$ 2.00$.

TUNICA Saxifraga. Pink. 6 to 10 inches. June to August. Delicate, attractive foliage. Sun. Each $20 \mathrm{c}$., doz. $\$ 2.00$.

VAIERIANA offinalis. Pink. 2 to 5 feet. June. Fragrant and showy foliage. Sun.

VERNONIA Noveboracensis (Ironweed). 5 feet Tall and vigorous growth, and good in back of borders. Intense purple flowers in large heads.

VERONICA (Speedwell).

amethystina. Blue. 12 inches. May and June. A creeping plant of unusual beauty. Sun.

gentianoides. Blue. 12 inchese. May. New and fine. Sun. Each 25c., doz. \$2.50.

"incana. Blue. 12 inches. June and July. Valuable for edging. Sun.

" longifolia subsessilis. Blue. 2 feet. August and September. Flowers erect and in large spikes. One of the most beautiful of hardy plants. Sun.

" rupestris. Blue. 4 inches. May and June. Creeping in habit. Good for edging and rockwork. Sun.

"spicata. Blue. 2 to 3 feet. June to August A very free bloomer and good to cut. Sun.

" var. alba. White. 2 feet. June to August. Sun. spicata var. rosea (Pink Speedwell). 1 to $1 \frac{1 / 2}{2}$ feet. A pretty border plant with conspicuous spikes of light pink flowers produced in June and July. Each 25c., doz. \$2.50.

VINCA (Periwinkle, or Trailing Myrtle).

minor (Myrtle). Blue. Vine. April to June. Evergreen and creeping. Fxcellent for ground covering or rockeries.

var. alba. A white flowering form of the above. Each $25 \mathrm{c}$.

' minor var. alba variegata (Variegated leaved Myrtle). Foliage white and green variegated. Flowers white. An interesting and rare sort. Each $25 \mathrm{c}$.

" minor var. aurea variegata (Golden-leaved Myrtle). Each $35 \mathrm{c}$.

" minor var. rosea (Pink Myrtle). Flowers single and rose-colored. A beautiful new variety. Good for rock gardens or ground covering. Each $25 \mathrm{c}$
VIOIA cornuta (Violet). Purple. 9 inches. April to August. A profuse bloomer and excellent for edging. Sun.

"var. alba. White. 9 inches. April to August. A white form of the above. Sun.

" cornuta var. Iutea major. Flowers continually from April until frost. A charming yellow variety. Each 20 c., doz. \$2.00.

" cornuta var. purpurea. Dark blue flowers produced freely all summer. New. A very attractive plant for the border or rock garden. Each $20 \mathrm{c}$., doz. $\$ 2.00$.

" papilio. Violet. 9 inches. April to August. Flowers very large. Sun. Each $20 \mathrm{c}$, doz. $\$ 2.00$.

"tricolor (Heart's-Ease). Deep purple, with yellow center. A miniature Pansy, extremely hardy. 6 inches. April to August. Sun.

" cucullata. Blue. 8 inches. April and May. Flowers very freely. Sun. Each $25 \mathrm{c}$.

"var. Wellsiana. Blue. 8 inches. April to October. Single, and a profuse bloomer. Sun.

Double Russian. Very double and sweet-scented. Each $25 \mathrm{c}$

\section{Hardy Ferns}

ADIANTUM pedatum (Maidenhair Fern). 18 inches. Handsomely cut fronds, with long, clean, ebony-black stems. One of the finest of the Maidenhairs. Each 25c.

DICKSONIA punctilobula (Gossamer Fern). 2 feet. Long, broad, deeply cut, light green foliage. A beautiful variety. Each $20 \mathrm{c}$.

ONOCrEA sensibilis (Sensitive Fern). 18 inches. Broad, triangular, light green fronds on long stems. Each 20c.

" Struthiopteris (Ostrich Fern). 5 feet. A magnificent hardy Fern, with beautifully cut fronds of a rich green. and the whole plant of elegant habit. Each $30 \mathrm{c}$.

CSMUNDA regalis (Royal Fern). 3 feet. One of the most graceful of Ferns. Pale green fronds which unfold in the most beautiful manner in early Spring. Folms a broad clump of graceful effect. Each $20 \mathrm{c}$.

" cinnamomea (Cinnamon Fern). 5 feet. Handsomely divided fronds, densely clothed with wool when young. Each $20 \mathrm{c}$.

PTERIS aquilana (Bracken). 4 feet. Coarse dull green and leathery foliage. Each $20 \mathrm{c}$.

WOODSIA Ilvensis. 6 inches. Forms a very charming tuft of numerous, finely cut fronds about 6 inches long and 2 inches broad. Each $20 \mathrm{c}$.

\section{Hardy Orchids}

For Wild Gardens, Rockeries, etc.

CYFRIPEDIUIM acaule. Bright pink flowers. Very showy. Each $30 \mathrm{c}$

" pubescens. Large, showy yellow flowers. Each $30 \mathrm{c}$.

"spectabile (Moccasin Flower). A most charming plant: easily grown. Clusters of elegant white and pink flowers. Each $50 \mathrm{c}$.

GOODYRA pubescens (Rattlesnake-Plantain). Leaves velvety green, veined with silver. Flowers grenish-white and in spikes. Good in rock gardens or for naturalization. Each $25 \mathrm{c}$. 


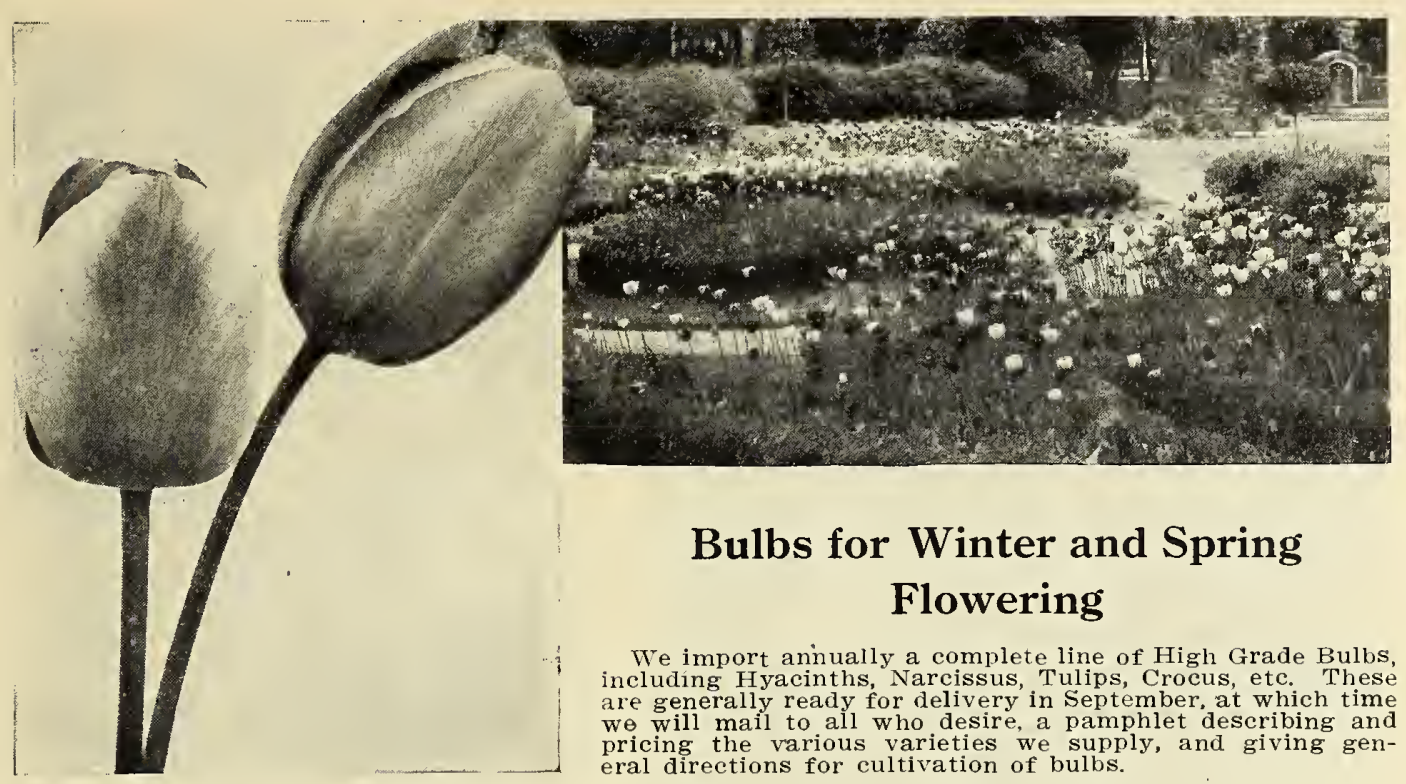

\section{Summer Flowering Bulbs and Roots}

\section{Begonias, Tuberous-Rooted}

We offer tubers from the finest strain of erect, large-flowered varieties, comprising all colors-red, scarlet, white, yellow, pink. etc.

Varieties in colors, either double or single, Each 15c., doz. $\$ 1.00$.

\section{Caladium}

Caladium esculentum (Elephant's Ear). A most effective and easily grown foliage plant for the lawn or border. Can be used with good effect as a border for tallgrowing Cannas when edged with Coleus or other low-growing foliage plants. Will thrive in any ordinary garden soil, but to get the best results plant in rich soil and give plenty of water.

Strong tubers ......Each $15 \mathrm{c}$., doz. $\$ 1.50$

\section{Cannas}

The following varieties comprise the best and most showy:

Each 15c., doz. $\$ 1.50,100 \$ 8.00$.

Austria. 6 feet. Pure canary yellow. Late. Beaute Poitevine. 4 feet. Large crimson.

Black Beauty. 5 feet. Bronze-leaved. Fine for foliage effect. If sold alone, each $25 \mathrm{c}$. Florence vaughan. $3 \frac{1 / 2}{2}$ feet. Rich, golden yellow, spotted with red.

Italia. 3 feet. Bright orange scarlet, yellow border.

Mme. Crozy. $3 \frac{1}{2}$ feet. Scarlet with golden edge.

Pink Beauty. 4 feet. Bright pink.

Pres. IrcKinley. 3 feet. Brilliant crimson. Queen Charlotte. 4 feet. Bright orange scarlet, margined with yellow.

Robusta. 6 feet. Large, dark foliage. One each of the above ten varieties for $\$ 1.00$.

We invite correspondence relative to any planting problem, and are always happy to assist our customers in making the best selection of material for any named purpose.

\section{Tuberose}

Excelsior Pearl. A superior strain with very large double white flowers, produced in great abundance. Extra strong roots. Doz. $35 \mathrm{c}$., $100 \$ 2.00$.

A splendid hardy climber - should be better known.

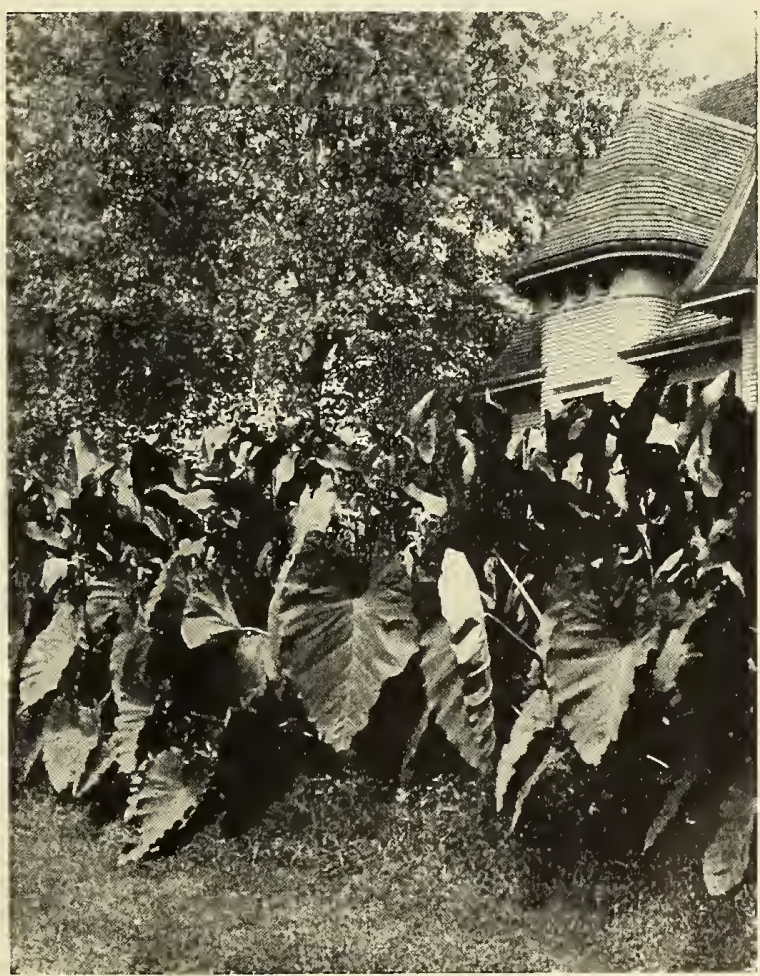

Caladium esculentum (Elephant's Ear) 


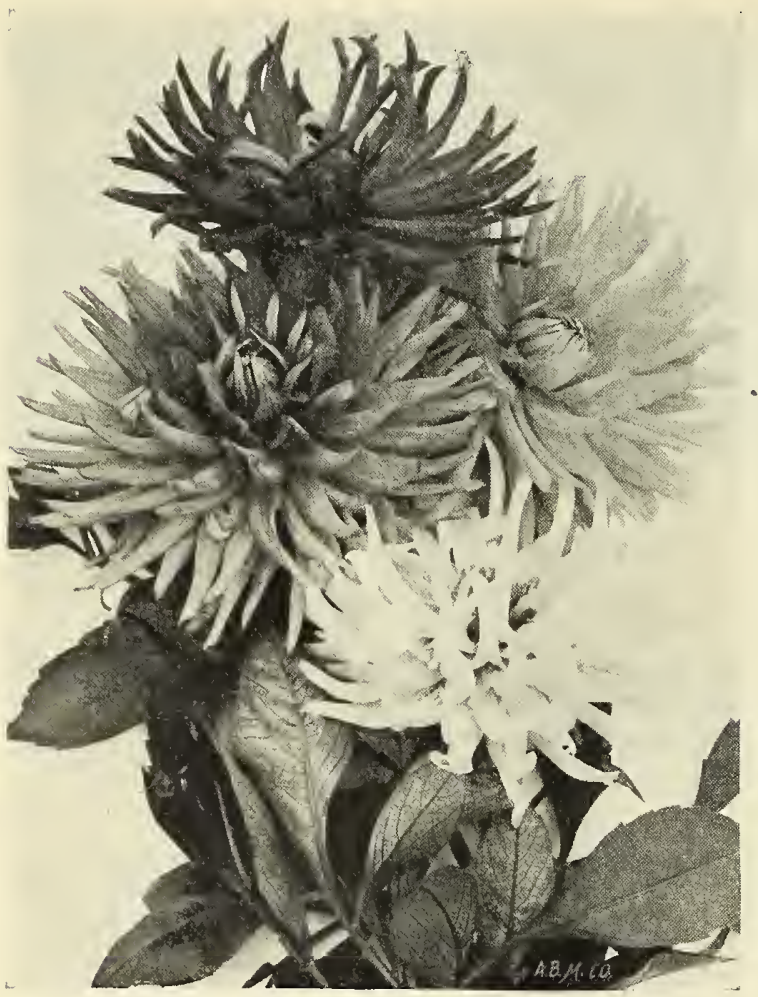

Cactus Dahlias.

\section{Dahlias}

The following list of varieties we have selected from among hundreds of sorts, many of them having been awarded Certificate of Merit, and we fully believe the collection to contain the best kinds possible to obtain.

Plants ready for delivery May 1st.

(Order by name or number).

\section{Cactus Dahlias}

A 1. Brantjungfer. Blush pink... Each A 2. Charles H. Curtis. Scarlet crimson $\ldots \ldots \ldots \ldots \ldots \ldots \ldots \ldots .25$

A 3. Fleider. Soft lilac ........35

A 4. Iauretta. Yellow, edged rose.. .25

A 5. Lawine. White .....................

A 6. Iovely Eynsford. Amber colored .35

A 7. Mrs. Clinton. Orange yellow... .25

A 8. Mrs. George Stevenson. Yellow. .20

A 9. IMrs. J. Emberson. Pale lemon, with rose-pink speckles....... .35

A 10. Rosea Superba. Rose..........35

A 11. William Marshall. Orange with yellow center................ .25

\section{Decorative Dahlias}

B 12. Alphonse Isore. Purple with vio-

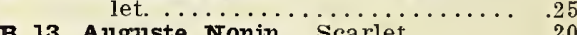
onin. Scarlet....... .20 B 14. Camillia. Coppery orange....... .20 B 15. Catherine Duer. Glowing red... .15 B 16. Delice. Pink $\ldots \ldots \ldots \ldots \ldots \ldots . .25$ B 17. Flora. White ............. 35

B 18. Gigantea. Sulphur yellow................

B 19. Jack Rose. Scarlet crimson..... .20

B 20. Jeanne Charmet. Pink, with yellow and white center....... Each

B 21. Mrs. Roosevelt. Pink $\ldots \ldots \ldots \ldots \ldots \ldots \ldots \ldots \ldots \ldots \ldots \ldots \ldots \ldots \ldots \ldots . . \ldots \ldots$

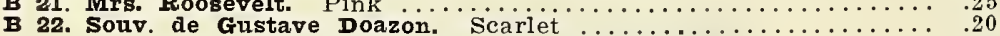

\section{Paeony-Flowered Dahlias}

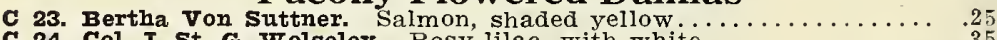

C 24. Col. J. St. G. Wolseley. Rosy lilac, with

C 26. Germania Wine color, with crim-

C 26. Germania. Wine color, with crim-

c 27. Glory and yellow $\ldots \ldots \ldots \ldots .20$

C 27. Glory of Baarn. Soft pink..........25

C 28. Hugo de Vries. Orange brown.....

c зо. . W. Janssen. Salmon, with yellow

C 31. Queen Augusta victoria. Whitish

$\begin{array}{lll}\text { C 32. Queen Emma. Lavender pink } \ldots \ldots \ldots & .20 \\ \text { C 33. Queen wilhelmina. White........ } & .20\end{array}$

\section{Show Dahlias}

D 34. Acquisition. Mauve $\ldots \ldots \ldots \ldots \ldots \ldots$

D 36. Gov. Guild. White

D 37. Purple Gem. Purple..............

D 38. Robony. Copper and amber shades

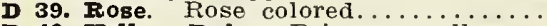

D 40. Yellow Duke. Primrose yellow.....

\section{Pompon Dahlias}

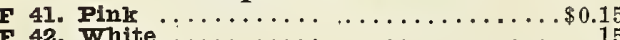

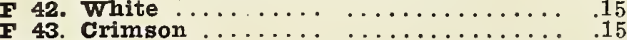

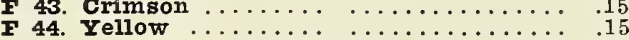

\section{Single Dahlias}

G 45. Mr. C. C. Yellow and orange scarlet....... $\$ 0.20$

G 46. Naomi Tighe. Sulphur yellow with orange.. .20

G 47. Polly Eccles. Rich satiny fawn..........20

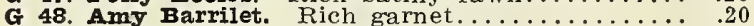

G 49. Cardinal. Cardinal red..................20

G 50. Crimson Century. Crimson ................

G 51. Twentieth Century. Red and white...........

\section{Mixed or Unnamed Dahlias}

We offer one dozen strong tubers, our selection, and all choice sorts, for $\$ 1.50,50$ for $\$ 5.00$.

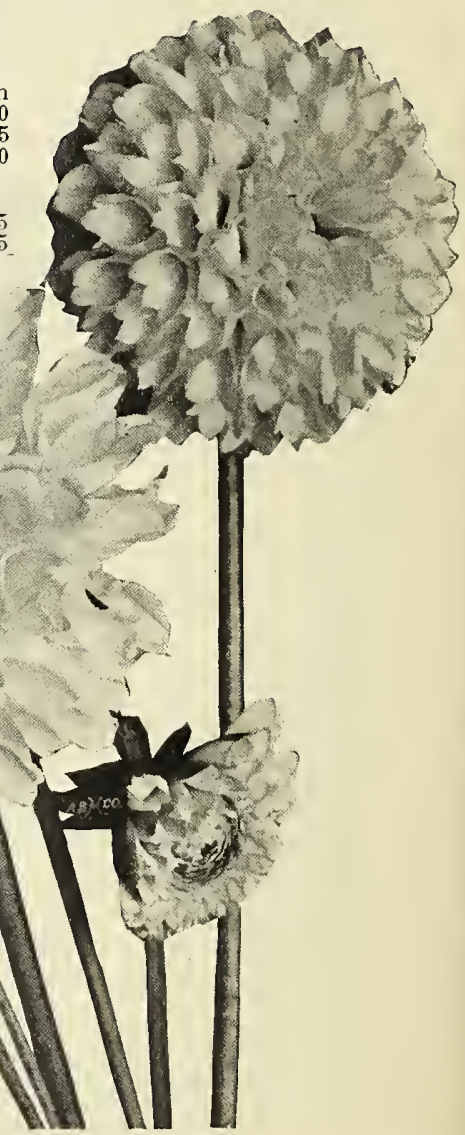




\section{Gladioli}

No flower appeals to the taste of everyone more than the Gladioli, and they should be found in every garden. To keep up a continuous bloom from June until frost; planting should be made every two weeks. Plant 6 inches apart in rows, 4 inches deep. After frost, lift and cut off near the bulb and store in any dry place where frost will not reach them.

America. A most charming, soft, delicate pink, tinted lavender. Large flowers on a strong spike. Doz. $\$ 1.00,100 \$ 6.00$.

Augusta. A fine white variety, with lavender anthers. Good for forcing. Doz. 50c. $100 \$ 4.00$.

Attraction. Deep rich crimson, with beautiful white throat. Doz. $\$ 1.00,100 \$ 6.00$.

Baron Hulot (Blue Jay), The best blue variety. Very dark, violet blue, with wellopened flowers. Doz. $\$ 2.00,100 \$ 15.00$.

Dawn. A most beautiful shell pink, slightly penciled in throat. A very fine variety. and a great favorite as a cut flower. Doz. $\$ 2.00,100 \$ 15.00$.

Fugene scribe. Soft, tender rose, blazed with carmine red. Doz. $\$ 1.00,100 \$ 6.00$.

Harvard. A perfect "Harvard" crimson; very popular as a cut flower and effective when used with green foliage. Long, graceful spikes of large open flowers. Doz. $\$ 1.50,100 \$ 10.00$.

Jean Dieulafoy. One of the most pleasing of the light varieties. Soft cream color with carmine blotch. Doz. $\$ 2.00,100$ with $\$ 15.00$.

Mrs. Francis King (The Original). A most beautiful flame pink. Immense flowers on a spike growing 4 feet high, with from 18 to 20 flowers; 6 to 8 open at one time. A magnificent variety. Doz. $\$ 1.00,100 \$ 6.00$.

Princess Sandersoni. The finest white variety, slightly penciled crimson. Beautiful for the home garden and commercial use. Doz. $\$ 2.00$, $100 \$ 15.00$.

Shakespeare. A very dainty white variety, slightly suffused with rose. Fine for outdoor planting and for forcing. Doz. $\$ 1.50,100 \$ 10.00$.

sunrise. A beautiful, clear, canary yellow, with no markings. Long spikes of dainty flowers, all open at one time. Fine for table or house decorations. Doz. $\$ 2.00,100 \$ 15.00$.

Postpaid-One each of the foregoing twelve varieties for $\$ 1.50$; two each, $\$ 2.75$; six each, $\$ 7.00$; twelve each, $\$ 13.00$.

Lemoine Hybrids. Mixed. Doz. 40c., $100 \$ 2.00$.

New England Mixture. A superb collection, giving a wide range of color. Flowers beautifully marked, and including many of the named varieties. Doz. $\$ 1.00,100 \$ 5.00$.

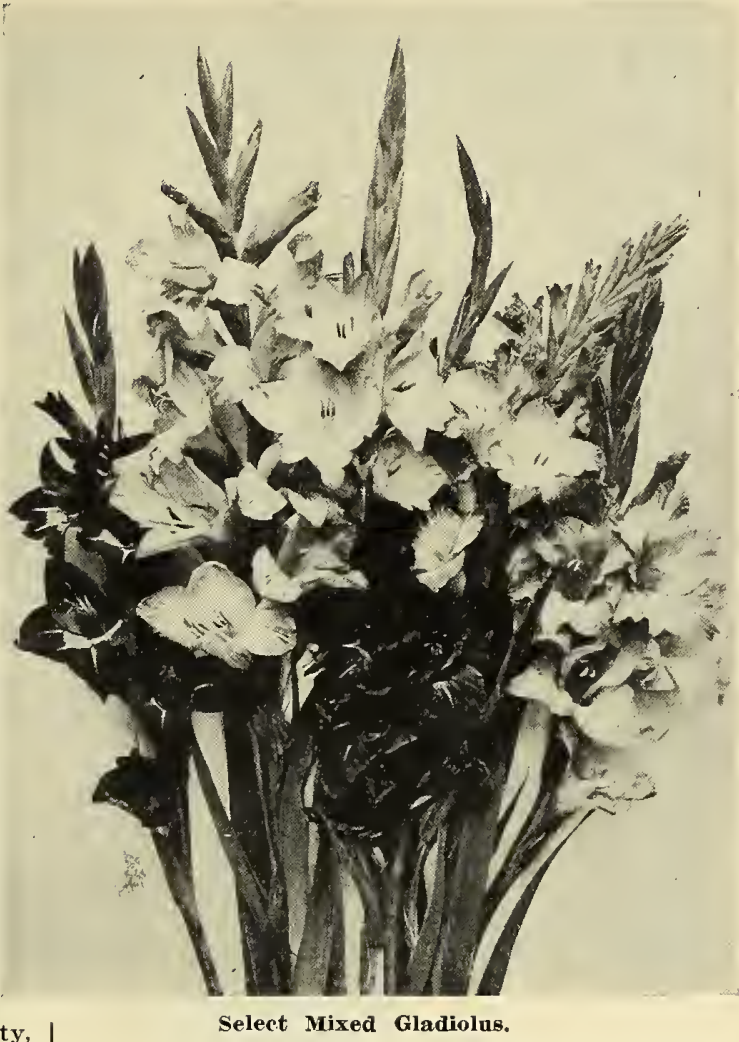

\section{Montbretias}

The Montbretia, unlike the Gladiolus, is a hardy summer-flowering bulb. It is most brilliant in color and should be planted extensively. Plant in clumps of six to twelve bulbs in May or June. Etoile de Feu. Bright vermilion; yellow center. Doz. 30c., $100 \$ 2.00$.

Gerbe d'Or. Golden yellow. Doz. 25c., $100 \$ 1.75$.

Transcendent. Orange and vermilion; large. Doz. $25 \mathrm{c} ., 100 \$ 1.75$.

\section{Tigridia}

A grand and useful summer-flowering bulb, flowering for a long period.

Prices, except where noted: Each 5c., doz. 50c.

Pavonia alba. White spotted.

Pavonia rosea. Rose color and white.

Speciosa. Scarlet.

Speciosa. Scarlet.

\section{Special Offer A. Complete Hardy Garden for $\$ \mathbf{\$ 1 6 . 5 0}$}

The following collection of Hardy Trees, Shrubs, Vines and Flowering Plants, sufficient for planting and ornamenting a medium sized cottage garden, we offer $F$. O. B. at Bedford for $\$ 16.50$. All stock first-class in every way and of sizes best adapted for general planting. For free delivery to points in New England, add 50 cents.

1 Baldwin Apple, 5 to $7 \mathrm{ft}$.; or 1 Silver Maple, $6 \mathrm{ft}$.

1 Gravenstein Apple 5 to $7 \mathrm{ft}$; or 1 White Ash $6 \mathrm{ft}$.

1 Cherry, $6 \mathrm{ft}$; ; or 1 Scarlet Hawthorn 4 ft.

1 Bartlett Pear 5 to $6 \mathrm{ft}$.; or 1 Tree Hydrangea $4 \mathrm{ft}$.

1 Elberta Peach $5 \mathrm{ft}$. or 1 Flowering Almond $2 \frac{1}{2} \mathrm{ft}$.

1 Concord Grape 2-yrs. old; or 5 Red Raspberries.

1 Worden Grape 2-yrs. old; or 5 Erie Blackberries.

2 Norway Maple 8 to $10 \mathrm{ft}$. or 2 Sugar Maples 8 to $10 \mathrm{ft}$.

1 Lombardy Poplar 6 to $8 \mathrm{ft}$.; or 1 Carolina Poplar 6-8 ft.

2 Bush Hydrangeas 18 in.

2 Rugosa Roses $2 \mathrm{ft}$

2 Red-barked Cornel $2 \mathrm{ft}$.

2 Forsythia, Golden Bell 2-3 ft.

2 Syringa, sweet scented $21 / 2 \mathrm{ft}$.

1 White Lilac, 2 to $3 \mathrm{ft}$.

1 Purple Lilac 2 to $3 \mathrm{ft}$.

2 Snowballs 2 to $3 \mathrm{ft}$.

2 Spiraea Van Houttei (Bridal Wreath) 2 to $3 \mathrm{ft}$.

6 Best Hybrid Roses (unnamed) 1 of each variety.

1 Pink Climbing Rose, or 1 J'apan Honeysuckle.

1 Star Clematis (Paniculata) or or 1 Trumpet Vine.

1 Boston Ivy or 1 Woodbine.
50 California Privet $21 / \mathrm{ft}$, or 25 Japanese Privet 2 ft., or 25 Japanese Barberries 15 to 18 in.

1 Blue Spruce $21 / 2 \mathrm{ft}$., specimen.

1 Norway Spruce $3 \mathrm{ft}$.

6 Mixed Hollyhocks.

6 " Larkspurs.

6 " Foxgloves.

6 "“ Canterbury Bells.

4 " Columbine

4 " Hardy Pinks.

2 New Hardy Asters.

6 Mixed Phlox.

6 “ Iris.

4 " Paeonies.

2 Japan Quinces 2 ft.

The above collection will appeal to many owners of small grounds, and when properly planted will materially add to the beauty of a home. In ordering, name the rarieties not wanted. 


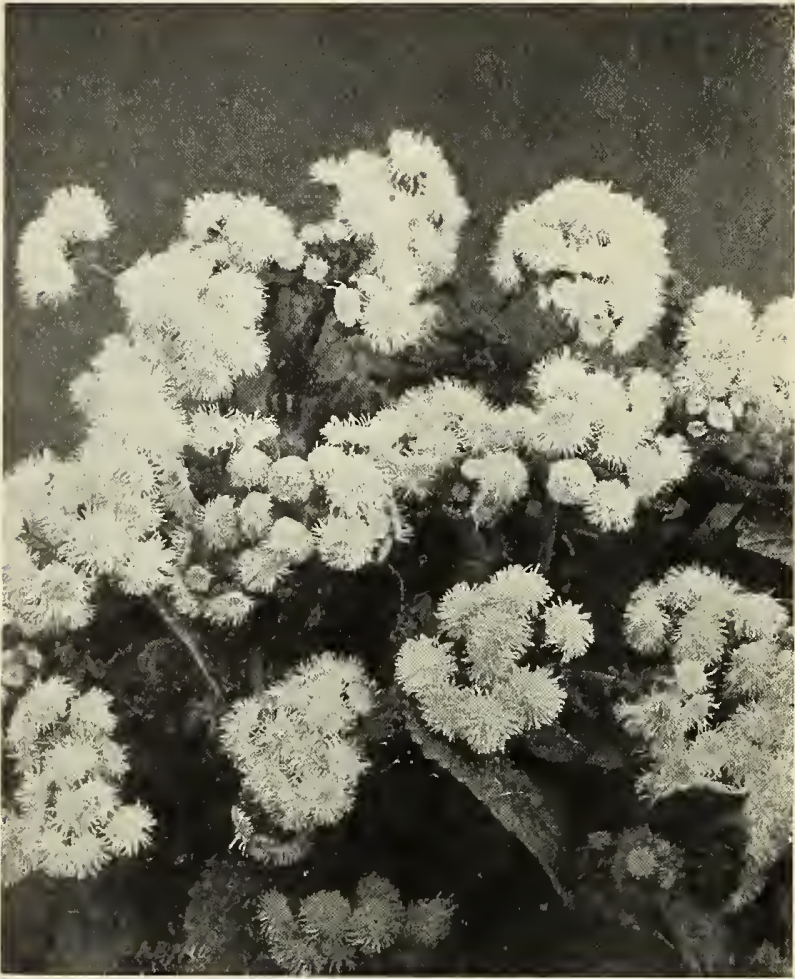

Ageratum.

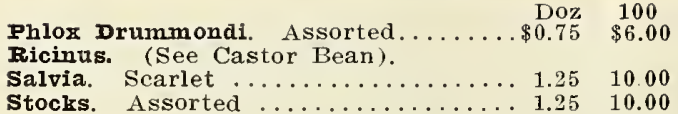

Geraniums

\begin{tabular}{|c|c|c|}
\hline & Doz & 100 \\
\hline Scarlet. & .51 .50 & $\$ 10.00$ \\
\hline Pink & .1 .50 & 10.00 \\
\hline white & 1.50 & 10.00 \\
\hline Variegated-leaved & 1.50 & 10.00 \\
\hline Sweet-scented .. & 2.00 & 12.00 \\
\hline $\mathbf{I} \mathbf{z y} \ldots \ldots \ldots$ & 2.50 & \\
\hline
\end{tabular}

\section{Old-Fashioned Herbs for Kitchen Gardens}

For medicinal purposes, flavorings, etc. a few Pot and Sweet Herbs are necessary for every garden.

Each Doz.

Allium Schoenoprasum (Chives) ... \$0.15 $\$ 1.50$

Artemisia absintheum (Wormwood) . $.15 \quad 1.50$

Dracunculus (Tarragon) $\ldots \ldots \ldots \ldots \ldots .20 \quad 2.00$

Hyssopus oficinalis (Hyssop) ........ .15 1.50

Iavandula veris (Lavender) .......... $.15 \quad 1.50$

Melissa officinalis (Balm) ...........15 1.50

Mentha piperita (Peppermint) ......... $15 \quad 1.50$

Mentha viridis (Spearmint) ...........15 $\quad 1.50$

Nepeta cataria (Catnip) ................ .15 1.50

Rumex crispus (Sorrel)..............15 1.50

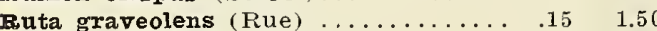

Salvia officinalis (Sage).............15 150

Thymms vulgaris (Thyme) .......... $15 \quad 1.50$

Are you familiar with the quality of our stock and the service we give? If not, inquire of your neighbor. Our trees and plants have made thousands of homes beautiful Our customers are our friends, because they rely on our word, and our stock succeeds well everywhere.

\section{Bedding Plants, or Annuals}

These plants should not be set out in open ground until all danger from frost is over.

Our bedding plants are all repotted or transplanted stock, and under proper conditions will take hold immediately after being planted.

Doz $\quad 100$

Achyranthes. Red or green-
leaved ............. $\$ 1.25 \$ 8.00$

Ageratum. Dwarf blue.... $1.00 \$ 7.00$

Alternanthera. Dwarf .... $.75 \quad 6.00$

Alyssum, Sweet ......... $.75 \quad 6.00$

Antirrhinum (Snapdragon).

All colors $\ldots \ldots \ldots \ldots \ldots \ldots$
sters. All colors ........

Begonias (Tuberous-rooted).

Started plants, all colors. $1.75 \quad 12.00$

Caladium (Elephant's Ear).

Started plants... Each 25c 2.00

Castor Bean (Ricinus). Red

or green-leaved. Each25c 2.00

Cobaea scandens Blue....

Each . Ail ...........20 1.50

Coleus. All colors . . . . . . .90

Fuchsias. Assorted colors. 1.55

Feverfew (Golden Feather) 75

Feliotrope ............ 1.25

Ivy, German. Excellent for

window-boxes ......... 1.50

Temon Verbena.....Each 20c 1.75

Iobelia (Crystal Palace).... .75

Marigold. Tall or dwarf... .75

Nasturtium. Dwarf.......

Myrtle, Common.......... $1.50 \quad 10.00$

Nicotiana (Tobacco Plant) .. $75 \quad 6.00$

Pansy. Selected strain.... $\quad .50 \quad 4.00$

Petunia. Assorted colors,

single $\ldots \ldots . . . . .1 .00 \quad 8.00$

Variegated Periwinkle, or Myrtle. Fine

for window-boxes ........Each $25 \mathrm{c} 2.50$

verbena. All colors............ .75

wallflower .............. 1.50

Zinnia. All colors ............ .50 4.50

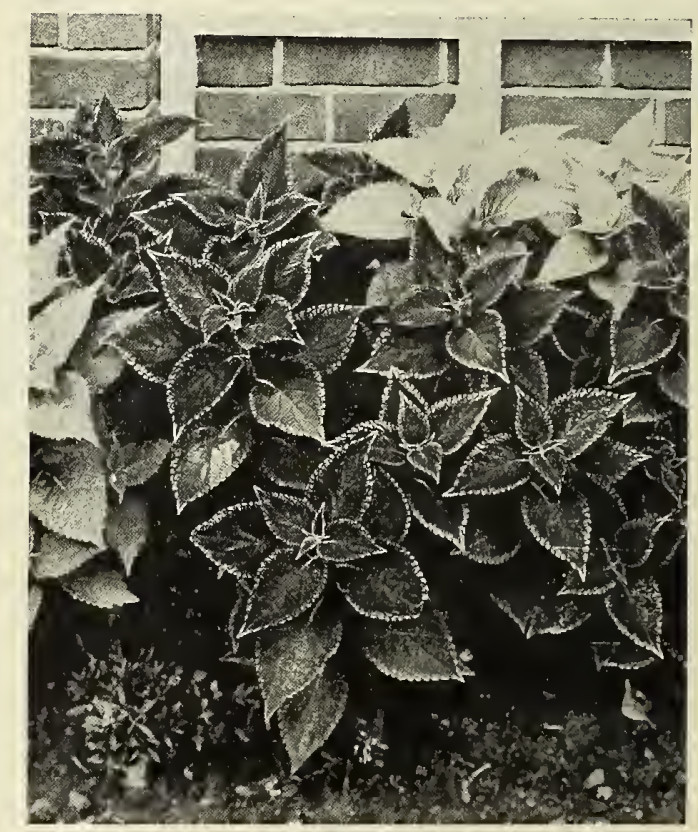

Coleus.

0.00

6.00

9.00

10.00

.00 .00 .00 .00 


\section{Fruit Trees and Small Fruits}

The varieties of fruit trees we offer below are such as can be particularly recommended, and are best adapted to the climate of New England. Any variety desired and not listed, we can generally supply from our Geneva, N. Y., Nurseries.

Pruning. Apples Pears, Cherries and Plums should at once after planting be pruned back to some extent, and it is generally well to remove from one-half to two-thirds of each branch. This treatment will insure a strong and healthy growth, and materially assist trees in taking hold.

Leading Orchardists now recommend the spacing of fruit trees in orchards as follows:

Standard Apples ........25 ft. apart

Dwarf Apples ......... $8 \mathrm{ft}$.

Standard Pears, ..... is to $20 \mathrm{ft}$

Sweet Cherries .........20 ft.

Sour Cherries............

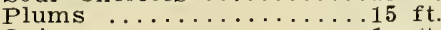

Quinces ................ It

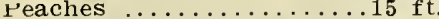

\section{Number of Trees Required to an Acre}

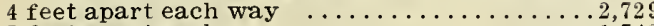

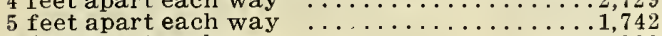

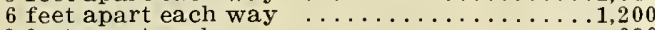

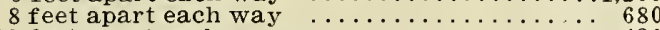

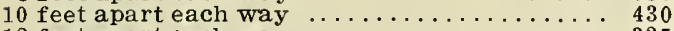

12 feet apart each way ............... 325

15 feet apart each way

\section{Apples}

First-class Standard Trees, 2 to 3 years old, 5 to 7 feet, each $50 \mathrm{c}$. doz. $\$ 4.00,100 \$ 30.00$

Dwarf Trees, 3 to 4 feet, not branched, on Paradise stock, each $50 \mathrm{c}$., doz. $\$ 5.00$.

We offer one-year-old trees of all the leading varieties of Apples, and of "Bedford grown" stock, at prices as follows: Each 25., doz, $\$ 2.00,100 \$ 12.00$.

Varieties marked with an asterisk (*) can be furnished on dwarf stock.

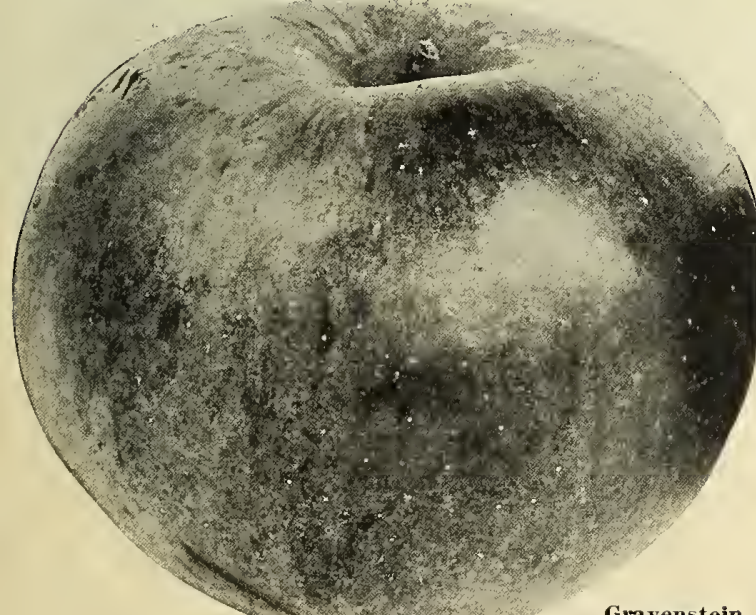

Gravenstein (See page 60 .)
Those marked with an $X$ we can supply in "Extra Heavy" specimens, and about 8 feet high, at $\$ 1.00$ each, and $\$ 10.00$ per dozen.

\section{Summer Apples}

Early Farvest. Moderate growth, medium to large; yellow; tender, rather acid; very good. ripening August.

Early Strawberry. Moderate growth, medium; deep red; melting, subacid; very good. Ripening August.

Golden Sweet. Free growth; large; yellow, tender sweet, rich; very good. Ripening August and September.

Primate. Medium growth; pale yellow; tender. fine flesh, juicy, mildly acid. Excellent dessert Apple. Ripening August and September.

$\mathbf{X} * \boldsymbol{R e d}$ Astrachan. Free growth; large, roundish; deep crimson; juicy, rather acid; good; very hardy; highly esteemed on account of its fine appearance, earliness and hardiness. Ripening August.

Sops of wine. Free growth; medium; dark crimson; juicy, subacid; good. Ripening August and September.

Sweet Bough. Moderate growth; large; pale yellow; tender, juicy, sweet; very good. August. Tetofsky. Moderate growth; Russian; medium; yellow and red; juicy, sprightly acid; good; very hardy. Ripening July and August.

*Willians Favorite. Moderate growth: large, oblong; red; rich and excellent. Ripening August.

*Yellow Transparent. Free growth; Russian; medium; roundish, oblate, slightly conical; pale vellow: tender, juicy, sprightly subacid; good. Ripening August. 


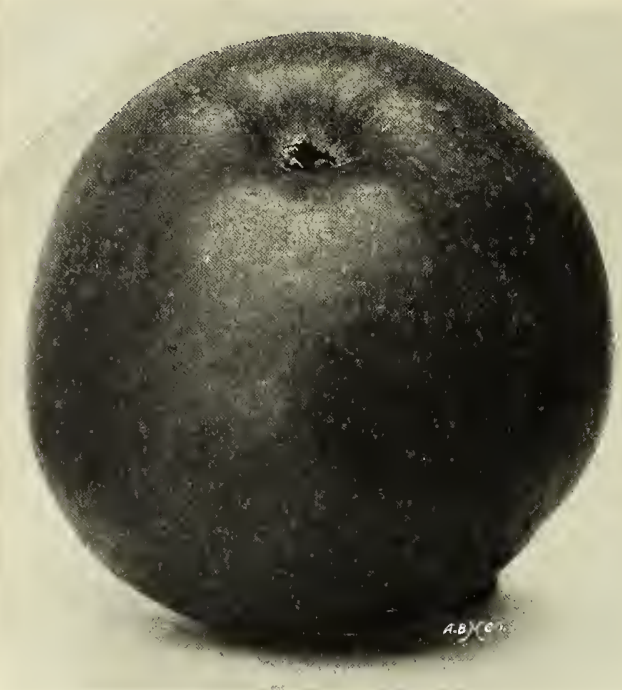

Baldwin.

\section{Autumn Apples}

Alexander. Moderate growth; Russian; very large and handsome; crimson; crisp, subacid; good. Ripening September and October.

Fall Pippin. Free growth; very large; yellow; tender, rich; very good or best. Ripening October to December.

* Fameuse, or Snow. Vigorous growth; medium; deep crimson; tender, subacid, melting, delicious; very good; hardy. One of the best dessert Apples. Ripening November to January.

$\mathbf{X} *$ Gravenstein, Vigorous growth; very large; striped; juicy, tender, crisp, rich, subacid; very good. Ripening September and October.

Maiden's Blush. Free growth; large; yellow and red; tender, juicy, subacid; good. Ripening September and October.

*Duchess of oldenburg. Vigorous growth; Russian; large; striped, tender, juicy, subacid; good; regular and abundant bearer. One of the hardiest kinds known. Ripening September.

Porter. Moderate growth; medium to large; yellow; fine grained; sprightly subacid; very good. Ripening September.

Pound Sweet. Vigorous growth; very large; yellowish; sweet and rich. Ripening October and November.

Red Bietigheimer. Free growth; one of the largest and handsomest Apples; purplish crimson; firm; pleasant subacid; good; hardy. Ripening September.

\section{Winter Apples}

$\mathbf{X} * \mathbf{B a l d w i n}$ Vigorous growth; large; bright red crisp, juicy, subacid; good; the most popular and profitable market sort in the East. Ripening December to March.

Belle de Boskoop. Vigorous growth; large; bright yellow; crisp, firm, juicy sprightly subacid; very good; hardy. Ripening December and January.

*Ben Davis. Vigorous growth; large; striped; moderately juicy, subacid; good; highly esteemed in the West. Ripening December to March.

Golden Russet. Vigorous growth; medium; russet; crisp, juicy, mild and subacid; hardy; very good; long keeper. Ripening November to April.

Grimes' Golden. Vigorous grower; large; golden yellow; juicy, sprightly subacid; very good. Ripening January to April.

* Iubbardston. Free growth; large; striped red and yellow; tender, juicy, rich, slightly subacid; very good. Ripening November to January.
Jonathan. Medium growth; red and yellow; tender, juicy and rich; very productive. One of the best for table or market.

Mann. Vigorous growth; medium to large; deep yellow; juicy, mild, pleasant, subacid; hardy. Ripening January to April.

$\mathbf{X} *$ McIntosh Red. Vigorous growth; handsome; very good; hardy. Ripening November to February.

Nero. A new Apple of great promise for New England. As large as Baldwin; bright red crisp, firm; good keeper; moderately juicy, mild subacid, mingled with sweet.

*Northern Spy. Vigorous growth; large; striped red; tender, juicy, mild, subacid; very good; a fine dessert fruit. Ripening December to June.

X Opalescent. The handsomest Apple on the market. An annual bearer of beautiful, high-quality fruit. Size large; color light, shading to a very dark crimson, and susceptible to a very high polish, hence its name. Ripening December to March.

Pewaukee. Vigorous growth; large; bright yellow with red; tender, juicy, subacid; good; very hardy. Ripening January to May.

Rambo. Vigorous growth; medium; yellow and red; tender, juicy, mild, subacid; very good. Ripening October to January.

X *Rhode Island Greening. Vigorous growth; large; green; fine grained; rich, subacid; very good. Ripening December to April.

Rome Beauty. Moderate growth; large; yellow and red; tender, juicy, sprightly subacid; good. Ripening December to May.

Rombury Russet. Free growth; medium; greenish; rich, subacid; good; late keeper. Ripening December to June.

Sutton Beauty. Free growth; medium to large; yellow and crimson; tender, juicy, subacid; very good and a long keeper. Ripening November to April.

Spitzenburg (Esopus). Large, round, brilliant red with gray dots; firm, rich, crisp, juicy, spicy and delicious. Tree rather a slow grower, but with high culture forms a large and spreading tree: a good bearer and a popular fruit. Ripening December to April.

Stark (Pride of Maine). An early and abundant bearer. Fruit large and valued for its long keeping; skin greenish yellow, shaded and striped with red, and thinly covered with light brown dots; flesh yellow, moderately juicy, mild. Ripening January to May.

Tolman's Sweet. Free growth; medium; yellow; firm, rich, sweet. Ripening November to April.

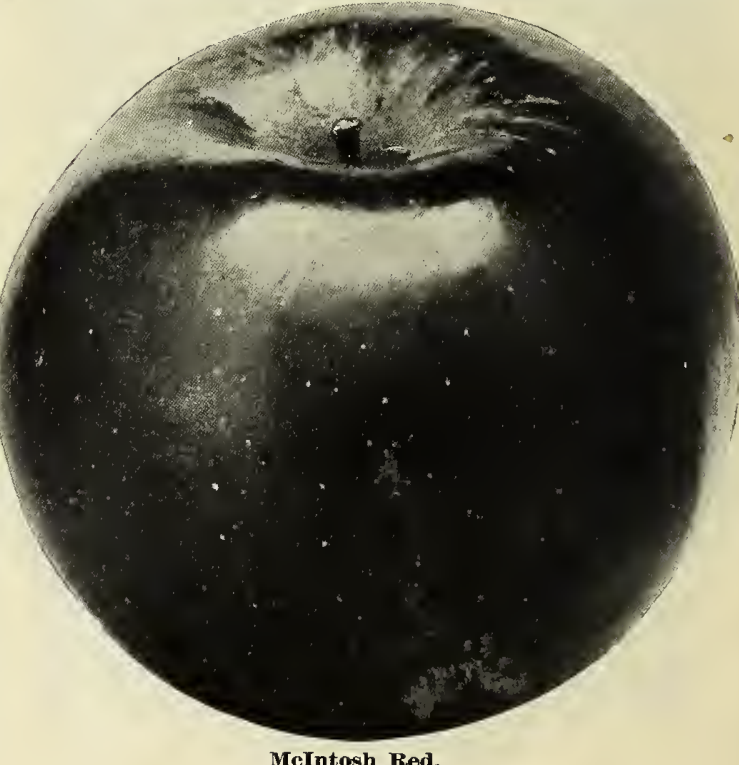

MeIntosh Fed. 


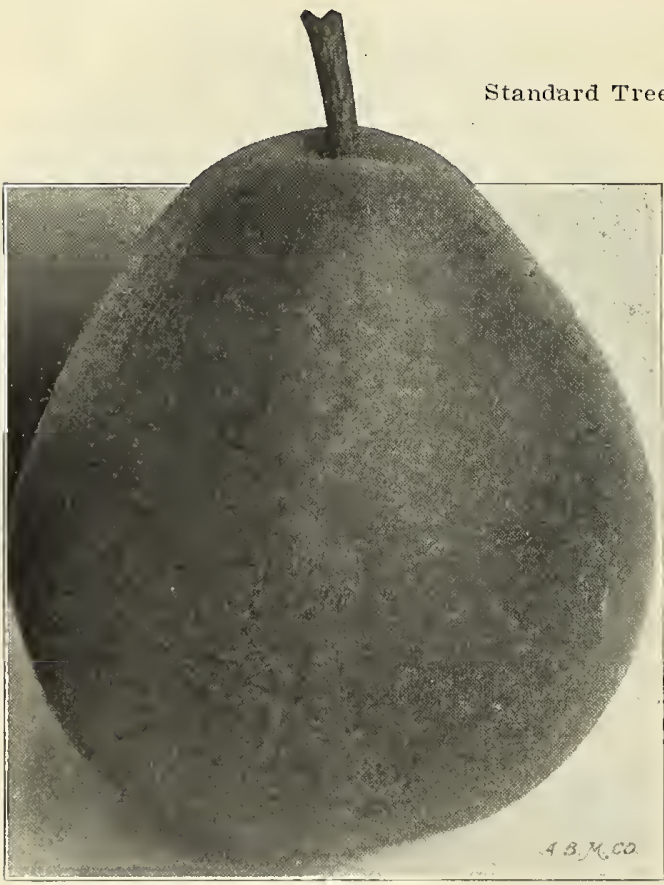

Seckel Pear.

PEARS-Continued.

\section{Autumn Pears}

Anjou. Vigorous growth; very large; greenish yellow; melting, buttery, juicy, sprightly, vinous; keeps into Midwinter; the most valuable of all Winter Pears. November and December.

Bosc. Moderate growth; large; russety; buttery, rich, high flavored; best. Ripening September and October (True variety). Each $\$ 1.50$.

* Clairgeau. Free growth; very large, handsome and showy yellow and red; juicy, vinous: valuable for market. November and December.

Flemish Beauty. Vigorous growth; large; yellow and russet; juicy, melting, sweet; good; very hardy. Ripening September and October

* Howell. Vigorous growth; large; handsome; sweet, melting; good. September and October.

rieffer. Vigorous growth; large; rich golden: slightly coarse; juicy, with a pronounced Quince flavor. Ripening october and November.

* Louis Bonne of Jersey. Vigorous growth; large; yellow and red; melting, buttery, rich; very good; Ripening September and October

* Seckel. Moderate growth; medium; brown; juicy, melting and buttery; of the highest flavor. Ripening September and october.

sheldon. Vigorous growth; large; russet and red; melting, rich, delicious; very good. October.

vermont Beauty. Originated in Vermont. A very brilliant-colored skin, and most beautiful when ripened. It matures a little later than the seckel and has qualities which render it valuable as a shipping Pear. Flesh rich, aromatic and juicy. The tree is strong in habit and is well adapted to the coldest climates.

\section{Winter Pears}

*Dana's Hovey. Moderate growth; small, but of fine quality. Ripening November to January.

*Iawrence. Moderate growth: medium to large; golden yellow, melting, pleasant, aromatic; very good; a valuable Winter Pear. Ripening November and December.

Iincoln Coreless. Practically coreless. It will keep for several months. Fruit large and juicy. When ripe, the skin is a rich golden tint, and the flesh yellow. Strong grower, hardy as Bartlett.

winter Nelis. Free growth; medium; russet; melting, buttery, and rich; very good; one of the best early Winter Pears. Ripening December and January.

\section{Cherries}

\section{Bigarreau or Sweet Cherries}

Black Fagle. Moderate growth; large; black, tender, rich, juicy; best. Ripening first of July.

Black Tartarian. Vigorous growth; very large; purplish black; one of the best. Ripe end of June Coe's Transparent. Vigorous growth; medium pale amber and red; one of the best. Ripening end of June.

Downer's Iate. Vigorous growth; rather large; light red; tender and juicy; good. Ripening: first of July.

Governor Wood. Vigorous growth; medium; clear, light red; tender, delicious. Ripe end of June. Napoleon. Vigorous growth; very large; pale yellow with red cheek. Firm, juicy, and sweet; very good. Ripening first of July.

Rockport. Vigorous growth; large, pale amber and red; sweet and tender; good. Ripening first of July.

Windsor. Vigorous growth; large; liver colored; very firm; very good. A valuable variety; hardy. Ripening end of July.

Yellow Spanish. Vigorous growth; large; pale yellow with red cheek; firm, juicy and delicious; very good. Ripening end of June.

\section{Morello or Sour Cherries}

Early Richmond. Medium size; dark red; juicy, rich acid flavor. The stone adheres to the stem. One of the most valuable of Sour Cherries.

Empress Eugenie. A new French Cherry, rather dwarf in habit; very productive; fruit large, roundish, flattened; skin rich, dark red; flesh red tender, rich, juicy, subacid; very good; stone small.

Montmorency (Large Montmorency). A Cherry of the Richmond class, but larger and more solid. A more upright grower, equally hardy, and a heavy cropper. Ripens from seven to ten days later than the Richmond entirely escaping danger from spring frost.

Morello, English. Large; dark red, nearly black; tender, juicy. subacid; valuable for preserves tree small, slender growth; productive.

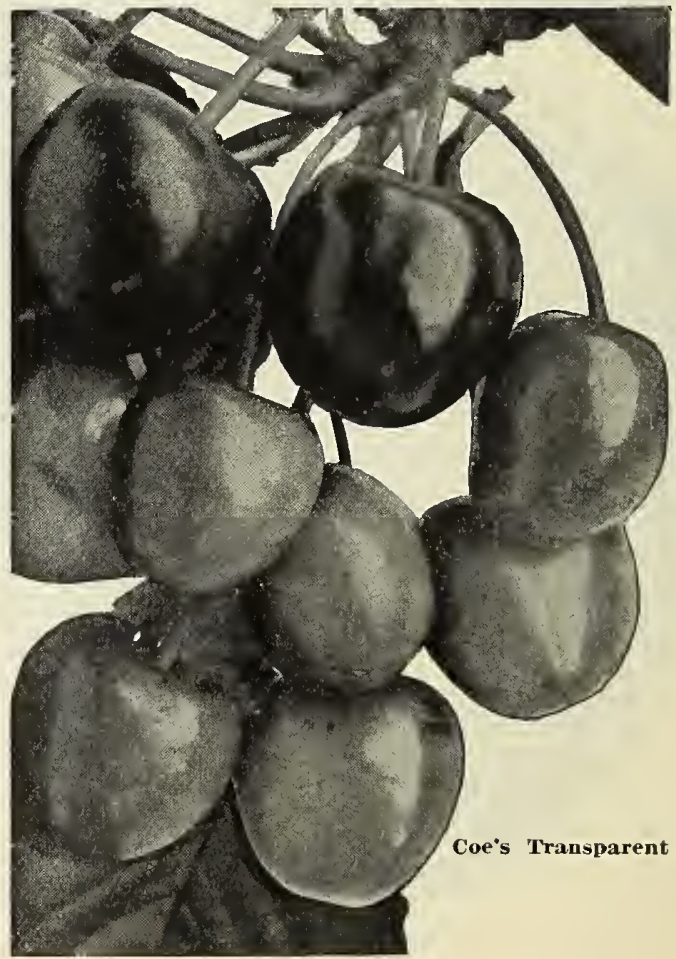




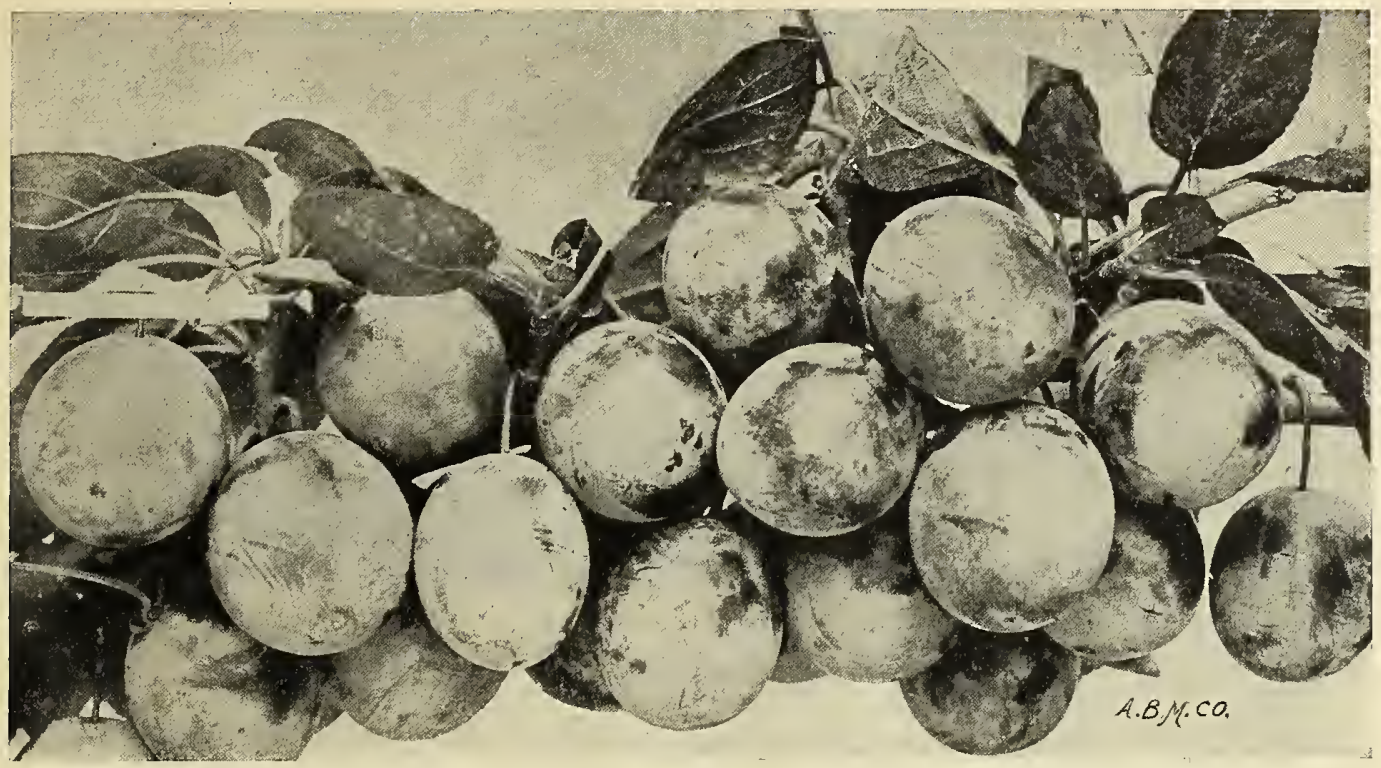

Red June Plums.

\section{Plums}

While Plums thrive on all soils, the best results are obtained when grown in deep, well-prepared loam. Black-knot, when it appears on the trees, should be removed by cutting out the branches affected. The curculio can be overcome only by jarring the trees and destroying the fallen insects. Spraying and thinning out of fruit produces best crops.

Trees, 5 to 7 feet: Each 50 cents; dozen, $\$ 5.00$.

\section{Plums of European Type}

Bradshaw. A very large, oval, dark violet red; juicy, sweet and good; a valuable market variety.

Coe's Golden prop. Tery large; light yellow; rather firm; rich, sweet and good; adheres to the stone. Tree moderately vigorous and productive. A valuable late variety. Last of September.

Iombard. Medium; oval; violet red; juicy, pleasant and good; adheres to the stone; tree vigorous and very productive.

Reine Claude (Bavay's Green Gage). Round; greenish yellow; juicy, melting, sugary, rich and excellent; separates from the stone; tree very vigorous and remarkably productive. A valuable market Plum. Ripens last of September.

Shropshire Damson. Originated in England. Dark purple; larger than the common Damson; very productive.

Shipper's Pride. Fruit large; color bluish purple, handsome and showy; flesh firm, of excellent quality; very productive, and a valuable market variety.

\section{Japanese Plums}

The Japan varieties are no longer experimental. as their success has given new life to the Plum culture. Large orchards are being planted, and are bringing good returns to their owners.

Abundance (Bhotan). Beautiful lemon-yellow ground, nearly overspread with bright cherry, and with a heavy bloom; large to very large, oblong, tapering to the point; flesh orange yellow, melting, rich and highly perfumed; abundant and annual bearer: tree a very vigorous, upright grower. Has been thoroughly tested, and is highly recommended. August.

Burbank. Large and beautiful, a clear cherry red, with a thin lilac bloom: flesh a deep yellow, very sweet, with a peculiar and very agreeable flavor. The tree is a vigorous grower, with large and broad leaves; usually begins to bear the second year after transplanting. Ripens later than the Abundance. End of August.
October Purple. Large, round fruit; dark, reddish purple yellow; flesh of most superb quality. Ripens middle of September. Its large, even size, beautiful color and superb quality make it very desirable for the garden or market.

Red June. An early-ripening Japanese Plum; medium to large; roundish; conical; purple red; handsome; flesh yellow; quality good.

Satsuma (Blood). Large, globular, with sharp point. Color purple and red, with bloom; flesh firm, juicy, dark red or blood color; fine quality; pit very small. August.

wickson. Originated by Burbank. A sturdy, upright grower; fruit remarkably handsome, deep maroon red, covered with white bloom; stone small; flesh fine texture, firm, sugary and delicious; excellent keeper and shipper; will keep two weeks after ripening.

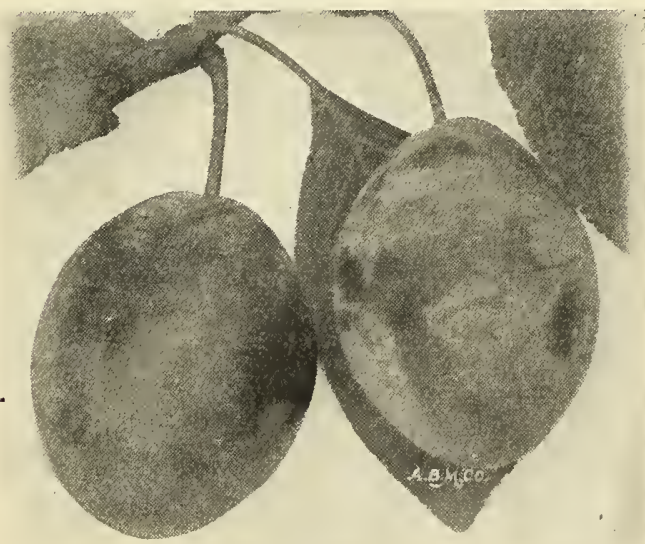

Damson Plum. 


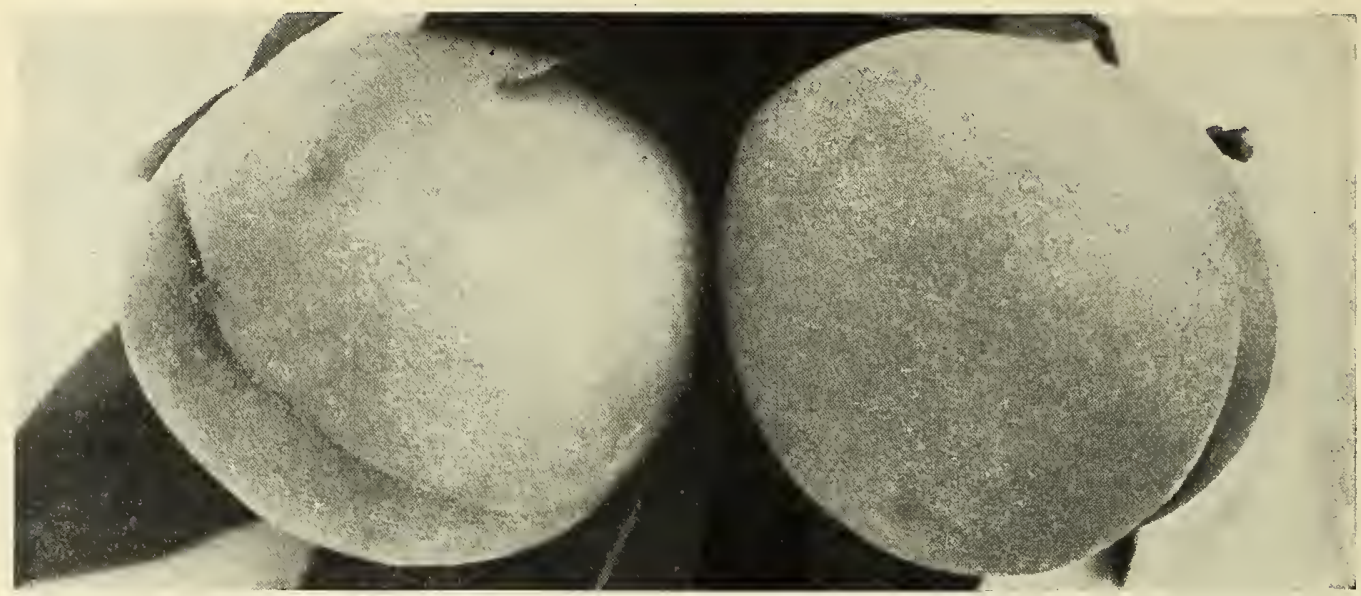

Champion Peach.

\section{Peaches}

The Peach tree requires a well-drained, moderately rich soil. Warm, sandy loam is probably the best. When the trees are first planted, all side branches should be cut back to within one-fourth to one-half inch of the main trunk, and the latter reduced one-third. The land immediately near the trees should be constantly cultivated. The following varieties have been selected out of hundreds, the best only being chosen. They furnish a succession for about two months, commencing the early part of August. Prices, first-class, 5 to 6 feet: Each $30 \mathrm{c}$, doz. $\$ 2.50,100 \$ 15.00$.

Alexander. This excellent variety ripens very early; large; color deep maroon, handsomely shaded; flesh firm, rich and good; most excellent shipper; freestone. Middle to last of July.

Belle of Georgia. Very large; skin white with red cheek; flesh white, firm, and of excellent flavor; fruit uniformly large and showy; free. Very hardy and one of the latest to ripen.

Carman. A new, hardy, rot-proof Peach. Large, round; pale yellow skin and red blush on sunny side; white flesh, sweet flavor.

champion. New. Handsome creamy white, with red cheek. It is of large size and of very superior flavor. Ripens about August 1, and has shown that it bears improvement over other white sorts.

Coolidge's Favorite. Medium; white and red; juicy and rich; freestone. Ripening end of $\mathrm{Au}$ gust.

Crawford's Early. Very large; yellow; juicy, melting; freestone. Ripening early September.

Crawford's Iate. Very large; yellow; juicy; good; freestone. Ripening end of September.

crosby. This is considered the best variety introduced for years, and is being extensively planted through New England, where hardiness is essential. It originated in Massachusetts.

Flberta. An exceedingly large, light-colored yellow Peach, a cross between Craw ford's and chinese Cling; juicy, well flavored; said to be probably the finest yellow freestone in existence; planted in enormous quantities in the Peachgrowing regions of the South. Ripens early in August.

Early York. Medium; greenish white, with red; juicy, rich. Ripening middle of August.

Fitzgerald. A chance seedling, found in Ontario, outside of the Peach belt, where it has produced regular crops. The fruit is of very large size. pit very small. This promising new Peach is of pit very small. This promising new Peach is of ty in size, hadiness and productiveness. Season same as Early Crawford.

Foster. Large, resembling Crawford's Early, but of better quality. Ripening early September.

Greensboro. The largest and most beautifully colored of all the early Peaches. Of good quality; juicy; freestone, but adheres slightly; ripens p

Mountain Rose. Large: white and red; juicy; good. Ripening end of August. oldmixon Free. Large; greenish white and red; juicy and rich. Ripening middle of September.

oldmixon cling. Large and excellent. Ripening end of September.

Rivers', or Early Rivers'. Large; creamy white, with pink cheek; melting, rich and racy; very good. Ripening early August.

stevens' Rareripe. Very productive and of high color; ripens immediately after Late Crawford, and continues three weeks.

stump the world. Medium to large; red and white; good. Ripening middle of September.

Triumph. New. A strong grower and a sure and abundant bearer. Fruit a freestone and of large size, and bright yellow color. Ripens early, and young trees háve borne over a half bushel of fruit each.

wheatland. Large; golden yellow, with crimson; juicy, sweet and of fine quality. Ripening middle of september.

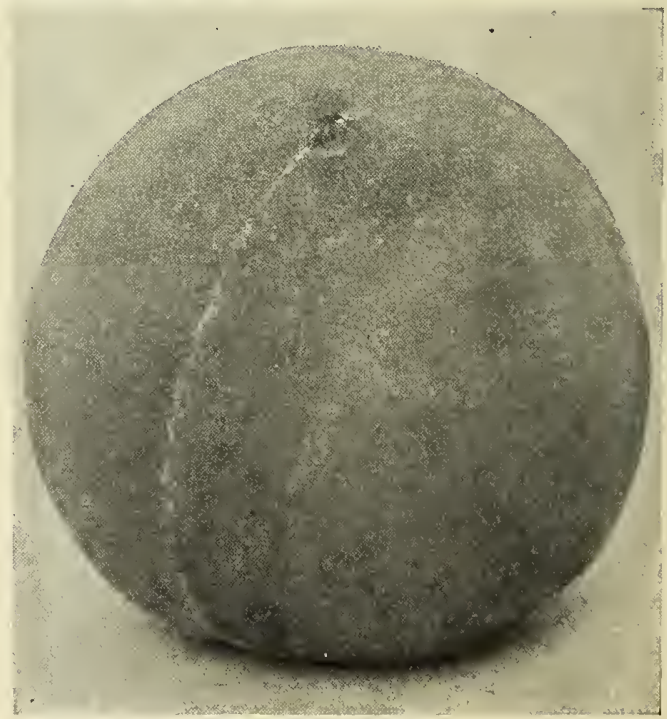

Elberta Peach. 


\section{Quinces}

The Quince is highly esteemed for cooking and preserving, and is most profitable for orchard planting. It requires good, deep soil, which should be kept clean and mellow, with an occasional dressing of manure. The tree is hardy and compact in growth and requires little space: is productive, bears regular crops, and comes in bearing early. First-class, 4 to 5 feet: Each $50 \mathrm{c}$; doz., $\$ 5.00$.

Bourgeat. A new variety of the best quality, tender and good. Ripening shortly after Orange, and keeping till past Midwinter.

Champion. The fruit is very large. Young trees, two years old from bud, are often loaded with fruit. Its season is about two weeks later than the Orange.

orange. Large, roundish, bright golden yellow; cooks quite tender, and is of very excellent flavor. October.

Meech's Prolific. Remarkable for its earliness and productiveness; will bear when two or three years old. Pear-shaped and of high quality.

Rea, or Rea's Mammoth. A very large and fine variety of the Orange Quince. One of the best.

\section{Apricots}

The Apricot succeeds well grown against walls or fences, and grown in this way can easily be protected.

On Plum stock: Each 50c., doz. $\$ 5.00$.

Alexander. Large; oblong; yellow; fine, sweet flavor. An immense cropper.

Blenheim. Medium; juicy and good. Very hardy. Early Golden. Small; pale orange; juicy and sweet. Hardy.

Farly Moorpark. Medium; rich; juicy; very fine. Moorpark. Large; yellow and red; sweet; juicy and rich; one of the best.

\section{Nectarines}

The Nectarine requires the same culture and management as the Peach, from which it differs only in having a smooth skin like the Plum. It ripens in September.

On Plum stock: Each 50c., doz. \$5.00

Boston. Large; bright yellow, with red; sweet and pleasant.

Farly Violet. Medium; yellowish green, with purple; melting, rich and high flavored.

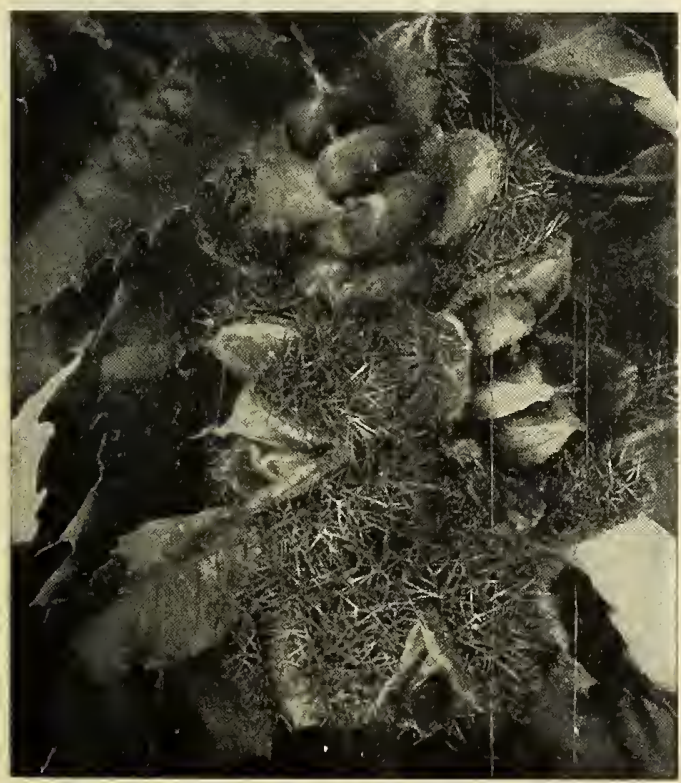

American Sweet Chestnut.

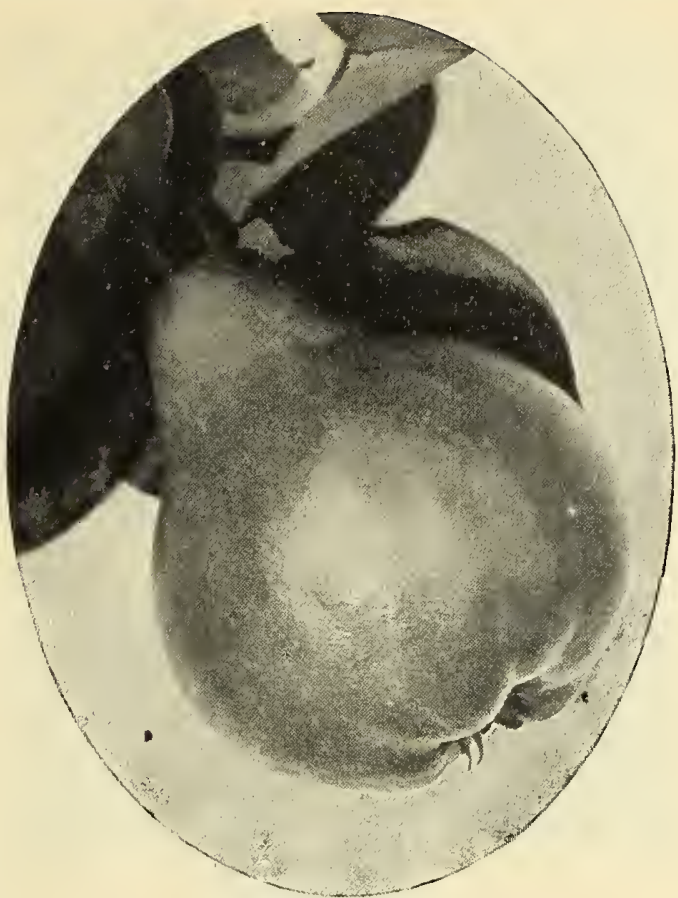

Champion Quince.

\section{Nut Trees}

Nut-bearing trees are admirably adapted for planting in streets, farm lanes, pastures, etc. for shade, ornament, and profitable returns.

\section{Chestnuts}

American Sweet. Nuts sweet and of delicate flavor.

4 to 5 feet ........... Each 50c., doz. $\$ 5.00$

Japanese Chestnut. This variety makes a tree about 30 feet high, but bears when five years old. The nuts are three times larger than the American variety, but not so sweet, yet superior to the Spanish nut. It is a highly ornamental tree. Each .................... \$1.00

Spanish. A handsome, round-headed tree, producing abundantly very large nuts that find a ready market at good prices. Not as sweet as the American.

4 to 5 feet ........... Each $\$ 0.75$, doz. $\$ 7.50$

Paragon (The famous "Sober" variety). A vigorous grower and an early, abundant bearer. Nuts very large, three or four in a burr, and particularly sweet and rich.

5 to 6 feet............ Each $\$ 1.00$, doz. $\$ 9.00$

\section{The Walnuts}

Black A native tree of large size and majestic form, beautiful foliage. Tree a rapid grower. producing a large, round nut of excellent quality 5 to 6 feet............ Each $75 \mathrm{c}$, doz. $\$ 7.50$

Butternut (White Walnut). A native tree of medium size; nut oblong and rough; highly prized for its sweet, nutritious kernel.

5 to 6 feet............ Each 75c., doz. $\$ 7.50$

English. A fine, lofty-growing tree, with a handsome, spreading head, It produces immense crops of thin-shelled, delicious nuts, which are always in demand.

5 to 6 feet........... Each $\$ 1.00$, doz. $\$ 10.00$

Japan. The nuts are considerably larger than the common Hickory nut, and borne in clusters of 15 to 20. The shell is a little thicker than that of the English Walnut, which it resembles in a general way. The trees begin to bear when two or three years old.

5 to 6 feet........... Each 75 c., doz. $\$ 7.50$ 


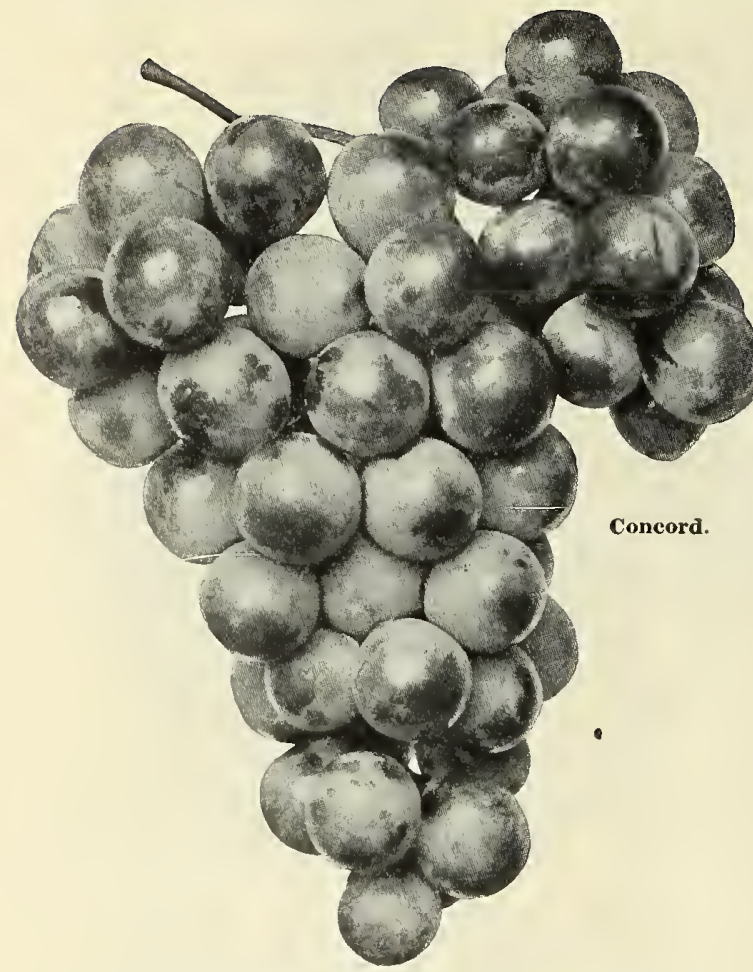

Hardy Native Grapes

Strong 2 and 3 -year vines. Price, except where noted: Each 30c., doz. $\$ 3.00,100 \$ 20.00$

\section{BLACK}

Campbell's Farly. A fine new grape; clusters large, compact and handsome; berries large, nearly round; black, with light purple bloom; flesh firm, but tender; the seeds few; quality rich, sweet, slightly vinous; a strong and vigorous grower. Each $50 \mathrm{c}$.

Concord. Bunch and berry large, round, black, thickly covered with a beautiful bloom; flesh moderately juicy, sweet pulp, quite tender when fully ripe.

Moore's Early. Bunch and berry large, with a blue bloom; quality better than Concord; its size and earliness render it desirable.

worden. Bunches large, handsome; berries large, sweet. Ten days earlier than Concord and superior to it in flavor; ripens well in cold localities.

\section{RED AND REDDISH PURPLE}

Agawam. Large, tender, juicy, vinous; vine vigorous.

Brighton. Large, handsome and of the best quality, and ripens early.

Catawba. Well known; highly flavored, but late.

Delaware. Medium or small, but delicious; highly esteemed everywhere.

Salem. One of the best and most popular of the Rogers; ripens with the Concord.

vergennes. Large and showy; pleasant, but not rich; ripens with the Concord; keeps well.

\section{WHITE}

Green Mountain. One of the very best; ripens early; good bearer; free from mildew; vigorous grower. Each 50c

Moore's Diamond. Bunch large, compact; berry about the size of Concord; color greenish white, with a yellow tinge when fully ripe; flesh juicy and almost without pulp; quality very good; vine vigorous and productive; early.

Niagara. Bunch medium to large; berry large; skin thin but tough; slightly pulpy, tender. sweet: vine vigorous, healthy, and very productive; ripens with Concord. All things considered, probably the most valuable white Grape in cultivation.

\section{Small Fruits}

\section{Blackberries}

Strong plants: Doz. $\$ 1.00,100 \$ 5.00$.

Agawam. Fruit medium size, jet black, sweet, tender and melting to the core; 'a very valuable variety for home use, being sweet throughout as soon as black; very hardy, healthy and productive.

Ancient Briton. Medium size; melting, without core. Hardy and very prolific. One of the best.

Eldorado. New. This splendid variety is, perhaps the best ever introduced. It stands when other varieties are Winter-killed, and has never failed to produce enormous crops of its very large, jet-black fruit, which are sweet and melting, and keep well after picking.

Erie. Fruit very large, excellent quality. There is no berry that rivals it in combining hardiness, large size, earliness and productiveness

Rathbun. Fruit is very large, color intense black with a high polish, pits very large, with small seeds; flesh juicy, high flavored, sweet and delicious.

Snyder. A marvel for productiveness; fruit medium size, sweet and melting to the core; extremely hardy. standing the Winters where the Kittatinny and Early Harvest kill down.

Wachusett Thornless. Fruit of medium size, oblong, oval moderately firm and less acid than any Blackberry we have seen; the plant is said to do equally well on light and heavy soils; it is hardy and almost free from thorns.

\section{Dewberry}

Iucretia. A trailing variety of the Blackberry. ripening between the Raspberry and Blackberry. Fruit large and handsome.

Doz. . . . . . . . . . . . . \$1.00, $100 \$ 5.00$

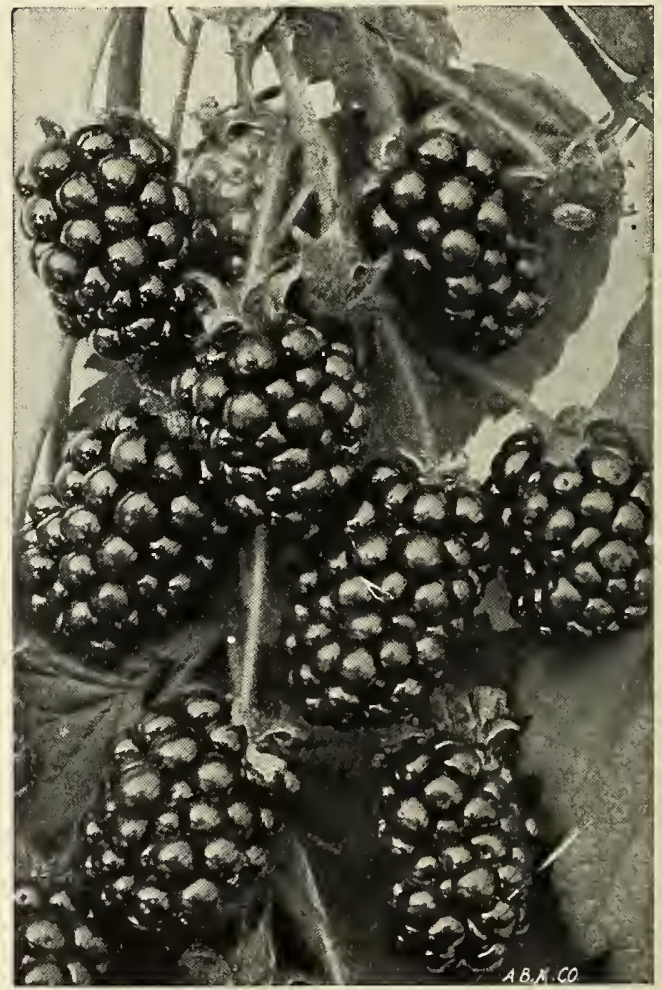

Erie Blackberries. 


\section{Raspberries}

Price, except where noted: Doz. $\$ 1.00,100 \$ 5.00$.

Black Diamond. Most prolific; berries black, of high quality and good size; productive and hardy.

Cardinal. The best of the purple Raspberries and a most desirable variety for home use. Vigorous in growth, ornamental in appearance and enormously productive.

Columbian. A new variety of great promise. It is a very vigorous grower and very hardy. Fruit purple and delicious for table or canning, and an excellent shipping variety.

Cuthbert (Queen of the Market). Large, dark crimson berries of firm texture, sprightly acid and of excellent quality; a certain cropper, always to be recommended.

Ioudon. Remarkably productive of bright red berries of largest size, fine quality and firm texture.

Marlboro. Large, bright crimson fruit of splendid quality, early and very hardy.

Golden Queen. Large, yellow fruit, of highest quality and best size; hardy and productive; fine for either home use or shipping purposes.

Doz. ................\$1.50, $100 \$ 7.50$

St. Regis Everbearing. (New). Red; berries of large size and of a bright crimson color. Flavor very sweet and rich; excellent quality. Highly productive and very hardy. Producing abundantly throughout the entire Summer.

Each .........20 c., doz. $\$ 2.00,100 \$ 12.00$

\section{Currants}

Two-year plants, except Perfection: Doz \$1.00, $100 \$ 8.00$.

Black Naples. Very large; black; bunches of medium length. Much valued for jellies. Strong grower and coarse leaves.

Cherry. Fruit of the largest size; deep red, rather acid; short bunches; growth strong, stout, erect; short-jointed shoots.

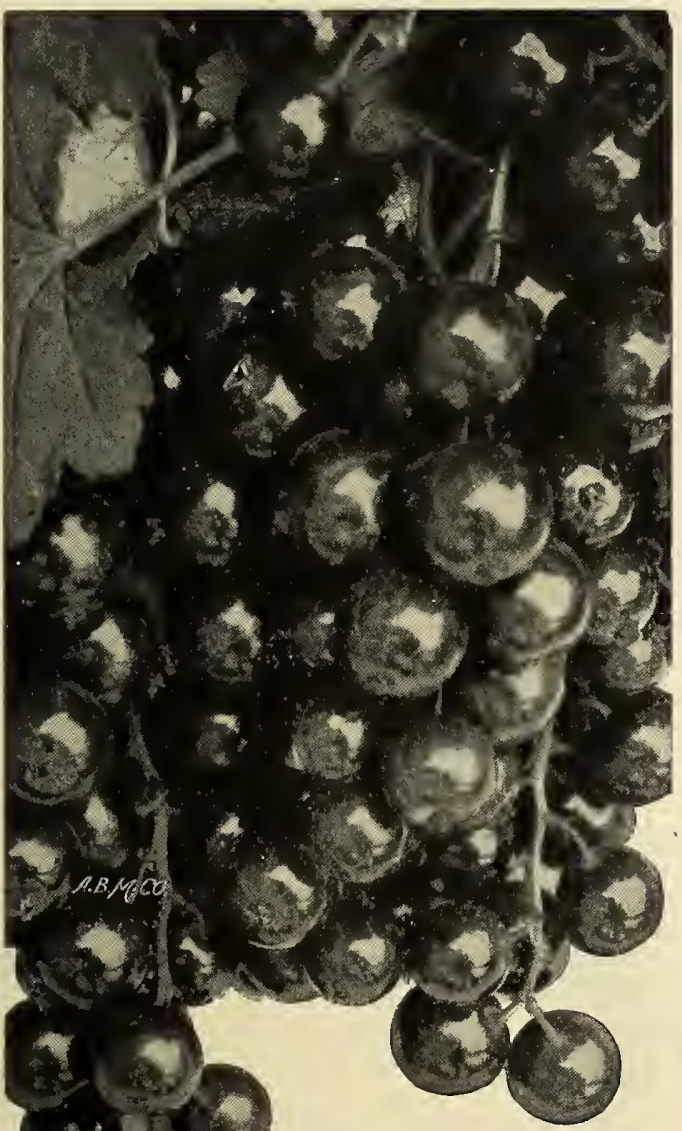

Perfection Currants.

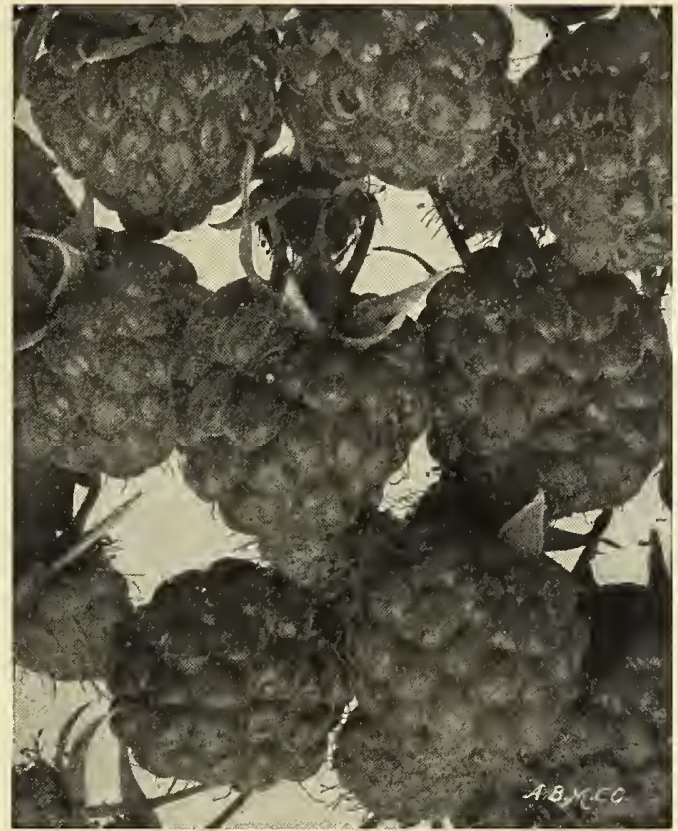

Columbian Raspberries.

Fay's Prolific. Fruit very large, bright red and of excellent flavor; less acid than the Cherry. It has a long stem which admits of rapid picking and is enormously productive.

I a Versailles. Very large; red; long bunches of great beauty and excellent quality. One of the finest.

Iee's Prolific. Black. The largest in berry and bunch, and in quality and productiveness.

Perfection. The color is a beautiful, bright red, size as large or larger than Fay's; the clusters averaging longer. The quality is rich, mild, subacid, plenty of pulp, with few seeds. After three years' trial, this fruit was the first to receive the $\$ 50.00^{\circ}$ Gold Medal of the Western New York Horticultural Society.

Doz. ...............\$2.50, $100 \$ 15.00$

White Grape. Very large, yellowish white; sweet, or a very mild acid. Excellent quality and valuable for the table. The finest of the white sorts.

\section{Gooseberries}

Columbian. The largest and most prolific Gooseberry in cultivation. Fruit dark red. Hardy. Each ..............40c. doz \$4.00

Downing. Whitish green; vigorous and prolific: juicy and good. A fine, reliable berry for general culture.

Doz. ...............\$150, $100 \$ 12.00$

Houghton. Vigorous but slender grower. Its medium pale red berries are plentiful and good, and it can be depended upon.

Doz. ...............\$1.50, $100 \$ 12.00$

Industry. An English variety more generally planted than any other, as it is free from mildew and bears freely very large dark red fruit of delicious quality. We recommend this for general use. Doz.

$\$ 3.00,100 \$ 20.00$

Pearl. The most prolific Gooseberry known. One bush produced 2500 berries. It is free from mildew, and is much larger than the Downing. The color is bright green and quality first-class. Being thoroughly tested, we offer it as the best of its class yet grown.

Doz. ..............\$1.50, $100 \$ 12.00$

White Smith (European). Fruit large, smooth. thin-skinned and tender; color yellowish green; sweet and very good. A very desirable variety. Each .................. 25c., $10 \$ 2.00$ 


\section{Pot-Grown Strawberry Plants}

Ready for Delivery in August.

The Strawberry will grow in any good garden soil where the ground has been thoroughly prepared. For family use we recommend planting them in double rows, 1 foot apart each way. Our pot-grown Strawberry plants are well-rooted healthy plants, ready for shipment in August, and by setting them any time during August and September, a fine crop of fruit may be had the next season. Out of the many varieties now on the market, the following sorts have proved the most satisfactory for growing in this locality.

Price: $\$ 3.00$ per $100, \$ 25.00$ per 1000 , except where noted.

Abington. Strong grower and great yielder. Large, bright red berries, firm and fine flavor. Early to medium.

Barrymore. This new Strawberry was awarded a Silver Medal by the Massachusetts Horticultural Society in 1908 . The plants are of strong growth and very productive. The conical-shaped berries are of medium size and of a dark, glossy, crimson color; the flesh is a rich red and very juicy. $\$ 4.00$ per 100 .

Brandywine. Large, glossy crimson; solid and fine flavor. Medium.

Bubach. Very early. Berry crimson and large.

Golden Gate. New seedling; resembles the Marshall, and will succeed where the Marshall fails. It produces strictly fancy, firm fruit, clear to the end of the season, of a rich crimson color.

Glen Mary. One of the most productive; very large, highly colored, firm, excellent flavor. Medium.

Hub. Large, firm, rich, glossy red fruit; very productive and best quality, and its season is very long. Doz. 75c., $100 \$ 4.00$.

Marshall. Large; rich crimson; fine flavor. Medium.

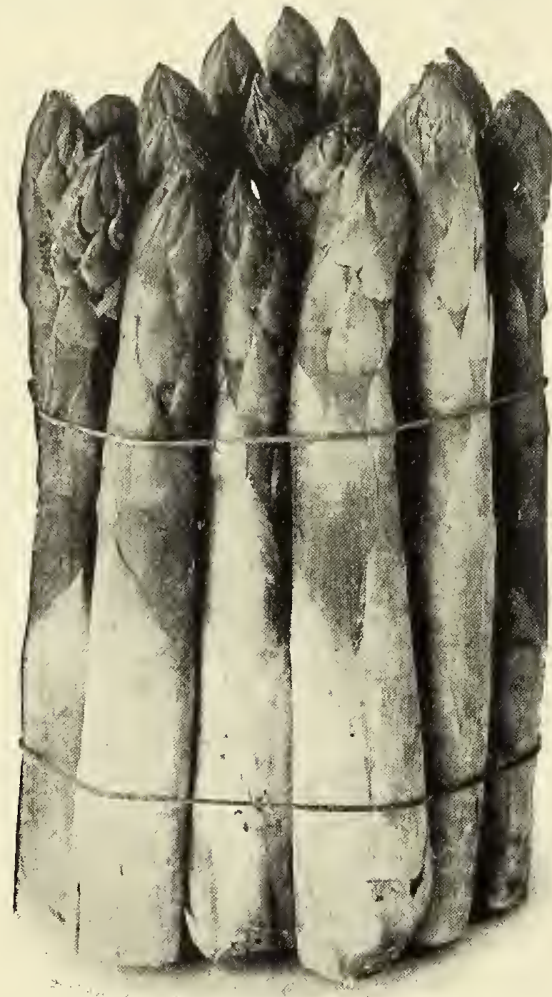

Conover's Colossal Asparagus.

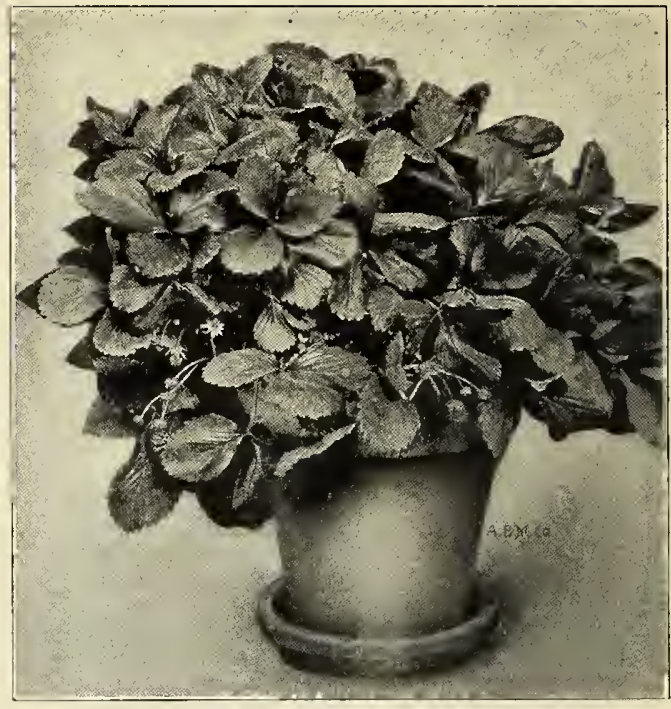

Pot-Grown Strawberry Plant.

Sample. P. Very large, bright scarlet, handsome form; fine quality; very prolific. Late.

Senator Dunlap. Early and very fine quality; large, rich, dark red and excellent flavor.

\section{New Everbearing Strawberry}

PAN-AIMERICAN. Perfect blossoms; a variety that produces a large and continuous crop of berries from August until the ground is frozen. Fine quality and good color. Doz. $\$ 1.75,100 \$ 10$.

\section{Strawberry Plants for Spring Planting}

The above named sorts can be supplied for Spring planting, and in "Runner-plants" at $\$ 1.00$ per 100, excepting Barrymore, Hub and Panper 100 , respectively.

\section{Asparagus}

An easily cultivated crop, capable of giving large returns, Set plants 5 to 6 inches deep, and in double rows, with the plants about 1 foot apart. We strongly advise salt to be used as a fertilizer. Forking the beds should not be neglected, as the early admission of sun and rain into the ground induces the plants to throw up shoots of superior size.

Conover's Colossal. Of large size, rapid growth and excellent quality.

$100, \ldots \ldots \ldots \ldots \ldots \ldots \ldots \ldots 1.00,1000 \$ 7.00$

Palmetto. A very popular variety of best quality.

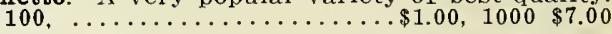
Our new Rust-Proof Giant Asparagus has been thoroughly tested, and appears to be perfectly immune from rust. It produces a large yield. and in and in quality it is second to none. it will supthat when it becomes better known, it will sup-
plant all other varieties. Strong, 2 -year plants. Doz. ...........50c., $100 \$ 2.001000 \$ 15.00$

\section{Rhubarb}

A deep, rich soil is indispensable to secure large, heavy stalks. Plant in rows four feet apart, with the plants three feet distant. Set so that the crowns are about one inch below the surface. Top dress in the fall with stable manure and fork under in the spring.

Champagne. A choice new English variety.

Each .................... doc., doz $\$ 5.00$

Iinnaeus (Myatt's). Large, early and of good quality 


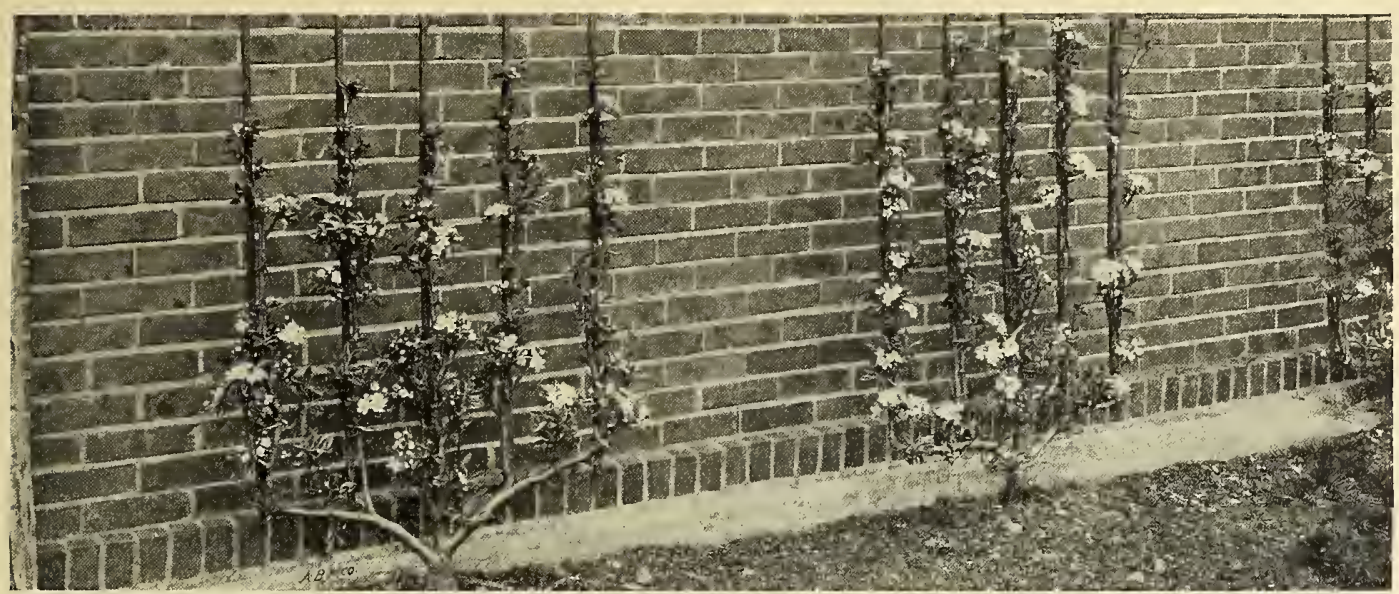

Trained Fruit Trees.

\section{Fan-trained Fruit Trees}

These are excellent for covering walls, trellises, etc, and produce the most perfect fruit. The trees we offer are imported from Northern Europe and are of the most hardy. They are grafted on dwarf stock, and can be relied upon to bear fruit the second season after planting.

of Apples, Pears, Cherries and Plums, we offer in fan-trained trees all the leading American varieties and also the wonderful old English Hawthornden Apple, the Count Moltke Pear, which is undoubtedly the most delícious of all Pears; and of Cherries, the old English Shade Morello, which is particularly good for training against walls or buildings where sunlight is limited.

\section{PRICES}

Fan-trained Apples, 5 to 6 feet.......Each, $\$ 3.50$ Fan-trained Cherries, 4 to 5 feet.....Each, $\$ 3.50$ Fan-trained Pears, 5 to 6 feet.......... Each, $\$ 3.50$ Fan-trained Plums, 4 to 5 feet $\ldots \ldots \ldots$. Each, 3.50

\section{Pyramid-trained Apples and Pears}

These trees are imported from Northern Europe also. They are dwarfed and of bearing sizes, and very stocky, They can be furnished in all leading varieties. Where the quickest possible results are desired, these should be planted in preference to native dwarf trees

\section{PRICES}

Pyramid-traíned Apples, 5 to 6 feet...Each, $\$ 2,50$ Pyramid-trained Pears, 5 to 6 feet....Each, $\$ 2,50$

\section{Special Offers No. 1, 2, 3 and 4}

\section{Special Offer No. 1}

20 OID-FASFIONED HTRBS TOR KITCHEN GARDENS PRICE $\$ 1.50$

(Delivery free to any point in New England). 2 Plants of Spearmint.

$$
\begin{aligned}
& 2 \text { “" “ Tarragon. } \\
& \text { “" " Hyssop. } \\
& \text { “ " "Balm. } \\
& \text { “" “Thyme } \\
& \text { “ “ "Sage. } \\
& \text { "Tarragon. } \\
& \text { “ Chives. } \\
& \text { “" Rue. } \\
& \text { “Lavender. }
\end{aligned}
$$

Special Offer No. 3

20 OLD-FASHIONED HARDY GARDEN PLANTS. PRICE $\$ 1.50$.

(For Free Delivery add 20 cents).

1 plant each of 20 unnamed choice varieties. All plants to bloom the first year, and of a selection to furnish flowers all through the season.

\section{Special Offer No. 2}

20 PIANTS FOR ROCK GARDENS. PRICE $\$ 1.50$ 2 plants each of the following interesting and rare varieties

(Delivery free to any point in New England). Adonis Vernalis (Spring Adonis). Ajuga reptans (Bugle). Alyssum saxatile (Madwort). A rabis albida (Rock Cress). Armeria robusta (Sea Pink) Asperula odorata (Sweet Woodruff). Campanula carpatica (Hare-bell) Campanula rotundifolia (Scotch Bluebell) Cerastium tomentosum (Mouse Ear). Dianthus deltoides (Maiden Pink).

Special Offer No. 4

20 BEST UNNAIMDD VARIFTIES OF HARDY PHLOX. PRICE $\$ 1.50$

(Delivery free to any point in New England).

1 plant each of 20 choice sorts, and of sizes to bloom the first season.

\section{Garden and Flower Seeds}

For the convenience of our customers, we have made arrangements with a most reliable Boston Seed House to furnish us, at low prices, with high grade Seeds, and we shall be pleased at any time, at regular seed store prices, to include with shipments of trees and plants any quantity of Garden and Flower Seeds required. 


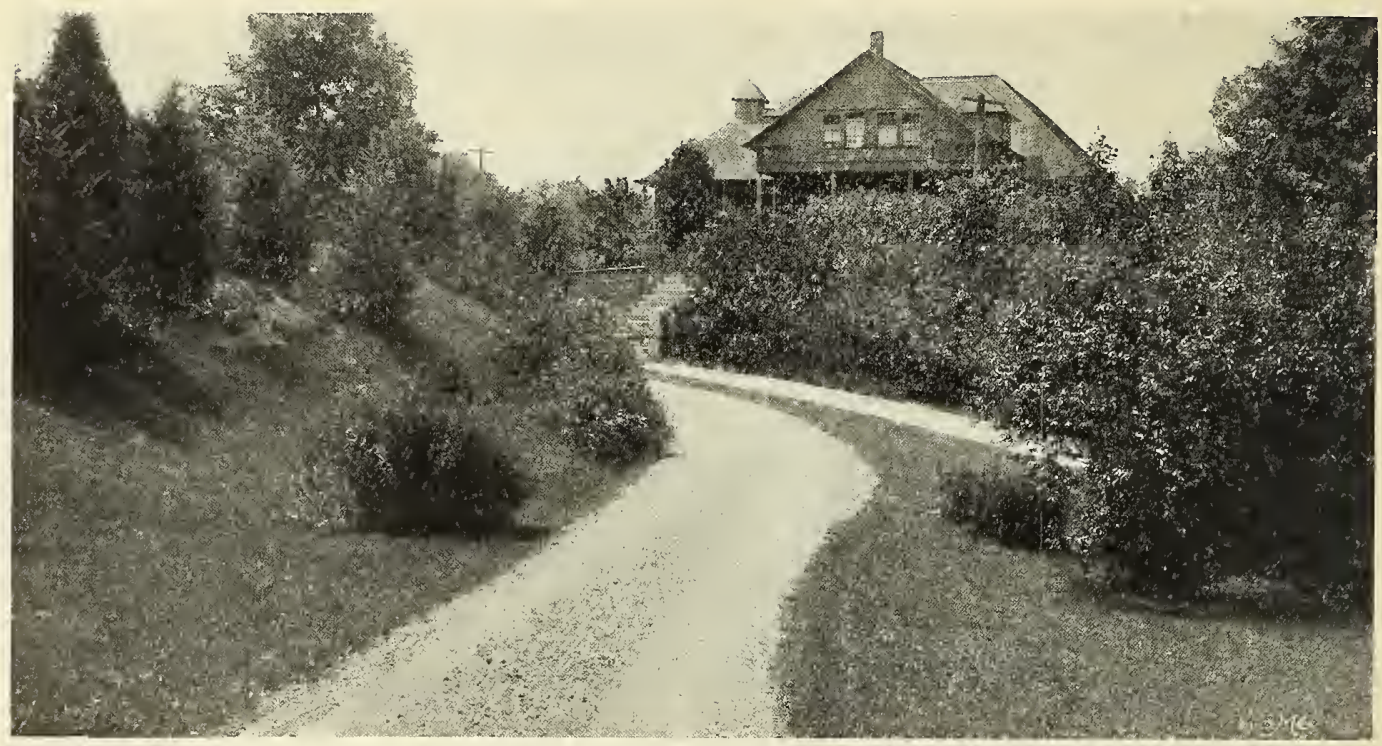

\section{Lawn Grass Seed}

\section{Bedford Special Recleaned Lawn Grass Seed}

A mixture particularly to be recommended. It produces a deep rich green, and a most perfect lawn. One quart will sow 300 square feet.

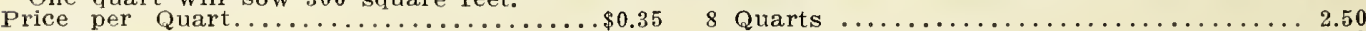

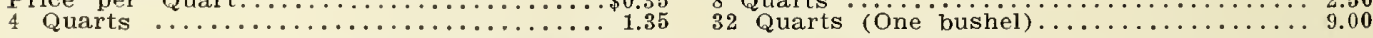

\section{Special Mixture for "Shady Spots"}

This mixture is particularly adapted for growing under trees or in places where sunlight is limited.

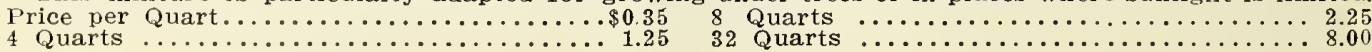

\section{Fertilizer}

\section{"Wolley Brand" Pulverized Sheep Manure}

We recommend pulverized Sheep Manure for all purposes where a high-class fertilizer is required As a top dressing for lawns it is unequaled; it car also be used with splendid success on golf courses, as well as on plants indoors. For lawns it should be applied at the rate of 500 to 600 tos. to the acre.

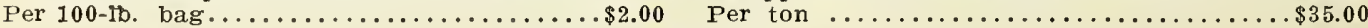

\section{Insecticides}

We are frequently called upon for advice regarding the safest and most effective Insecticides and Fungicides, and can particularly recommend the following:

\section{"Arlington Soluble Oil"}

For fungous diseases, scale insects, tent caterpillars and aphis eggs. It spreads quickly on the trees when used according to the directions given below, and sprayed thoroughly it will kill every scale that it touches. It cleans rough bark on old trees, and produces a strong green foliage. It has proven its superiority to any brand of Iime and Sulphur for San Jose Scale. Time and Sulphur can only kill scale actually sprayed upon, while Arlington Brand Soluble Oil not only kills scales that it is sprayed upon, but owing to its spreading qualities, also those near.

\section{Directions for Mixing}

Before using Arlington Soluble Oil, and before diluting with water, see that the preparation is thoroughly mixed by stirring or shaking. If to be used on Dormant trees, add 15 parts of water to one part of oil. For Summer Spraying, it should not be used stronger than one to sixty. Do not use on Maple Trees. Do not use at freezing temperature.

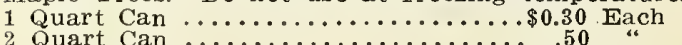

1 Gallon Can

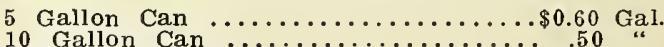

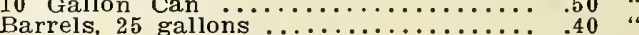

Barrels, about 50 gailons ....................

For Leaf-Eating Insects

For checking the ravages of such pests as the Gypsy Moth, Browntail Moth, Fall Web Worm, Tent Caterpillar, Elm Leaf Beetle and Spruce or Pine-bud Moth, spraying with Alsenate of Lead is the most effective remedy known. The dry powdered form of Arsenate it the most satisfactory for general use, as, unlike that supplied in paste form, it is easily prepared for spraying, is not injured by frost, does not harden in packages, and does not deteriorate with age. Many brands are offered for sale; but we have had the most excellent results with, and can particularly recommend

\section{Sherwin Williams Dry Powdered Arsenate of Lead}

\section{Use 1 pound to 16 gallons of Water.}

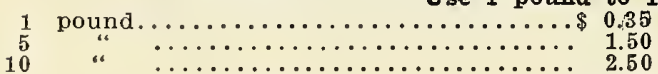

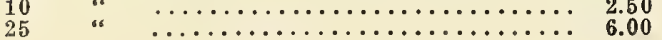

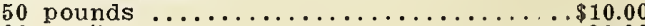

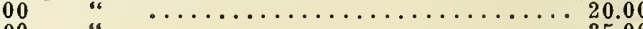


Abies

Acacia $\ldots \ldots \ldots \ldots, \cdots$

Acanthus ........41

Acer .............16 Achillea $\ldots \ldots \ldots \ldots$........

Achyranthes $\ldots \ldots . . . \% 58$

Achyranthes $\ldots \ldots .58$

Aconitum $\ldots \ldots \ldots \ldots 41$

Actinidia $\ldots \ldots \ldots 39$

Adlantum $\ldots \ldots .54$

Adonis $\ldots \ldots \ldots . . . .41$

Aegopodium .......41

Aesculus ...........17

Ageratum ......5.58

Agrostemma .....41

Ailanthus .......17

Aira ............ 41

Alugia ….......4

Alder $\ldots \ldots \ldots \ldots \ldots 17$

Alkanet $\ldots \ldots \ldots \ldots . . .61$

Allium ........58

Almond, Flowering 31

Alnus Ahrift .....47

Alstroemeria ….4.4

Alternanthera ......58

Althea ......28, 41

Alyssum …...41, 58

Amelanchier .....24

Amorpha $\ldots \ldots \ldots 24$

Ampelopsis ........

Amsonia $\ldots \ldots \ldots \ldots 41$

Anaphalis $\ldots \ldots \ldots \ldots 41$

Andromeda, $13,14,17$

Anemone .......42

Angelica Tree ...17, 24

Anthemis .......41

Anthericum ........41

Antirrhinum $\ldots \ldots .58$

Apios $\cdots \cdots \cdots 42$

Apples ...... 59-61

Apricots $\ldots \ldots \ldots .665$

Aquilegia ...........42

Arabis ..........42

Aralia $\ldots \ldots \ldots 17,24$

Arctostaphylos .....13

Arenaria $\ldots \ldots \ldots .42$

Aristolochia .....39

Armeria ........42

Aronia ..............

Arrow-wood ..........34

Arundo $\ldots \ldots \ldots, 42$

Artemisia .... 42, 58

Ascleplas .............

Ashberry ........... 14

Asparagus .......68

Asperula .......44

Asphodelus …

Astilbe ............4

Aubretia .........43

Azalea ........

Baby's Breath . . 46 Bachelor's Button..52 Bald Cypress . ....2.23 Balm ........49, 58 Baneberry .......4 Baptisia ….......4 Barberry ……...24 Bastard Indigo ...24 Bayberry …....30 Bay Trees .......14 Beach Plum .......31 Bearberry ..........13 Beard Tongue .....50 Bear's Breech .....41 Beech …........
Bellflower .....550

Bellis .........43

Benzoin.. .2 .24$

Bergamot $\ldots \ldots \ldots \ldots 49$

Betula .............

Bignonia $\ldots \ldots \ldots \ldots 40$

Biota $\ldots \ldots \ldots \ldots \ldots .8$

Bird Nesting-houses 4

Bishop's Hat ......46

Bittersweet ..........39

Blackberries …...66

Blackberry Lily ....50

Black-Eyed Susan 52

Bladder Senna …25

Blanket Flower ...46

Bleeding Heart ...46

Blind Gentian ...446

Blood Root .......

Bluebells ..........43

Blue Bells of Scotland

Blueberry …........

Blue Bonnet …...52

Blue Leadwort ....52

Blue Spirea....25, 43

Bocconia $\ldots \ldots \ldots \ldots 43$
Boltonia $\ldots \ldots \ldots 43$

Boston Ivy ...........

Bouncing Bet ....52

Bowman's Root ...46

Box Thorn ......30

Boxwood ...........13

Bramble .............

Broom …....28

Buckthorn..... .31

Bugle ............41

Buphthalmum ....43

Bush Roses ........31

Butterfly weed $\ldots . .42$

Butter Vetch .....49

Button Bush ......25

Button Snake Root 46

Caladium ....55, 58

Calimeris .......43

Callirhoe ........43

Calluna ...........13

Calycanthus ....24

Campanula ........43

Candytuft ........47

Cannas .......

Caragana .......17, 25

Carpinus $\ldots$

Caryopteris $\cdots \cdots 25$

Cassia ..........43

Castor Bean .......48

Catalpa ..........18

Catananche ......44

Catchfly ........53

Catnip ..........58

Ceanothus ..........

Cedar ............8

Cedrus $\ldots \ldots \ldots \ldots 8$

Celastrus .......39

Celtis ...........18

Centranthus .......44

Cephalanthus $\ldots \ldots 25$

Cerastium ........44

Cerasus .........18

Cercidiphylium ....18

Cereis ..........18

Chamaecyparis .....46

Chamaecyparis ...11

Cherries $\ldots \ldots \ldots \ldots .64$

Cherry, Flow'g 18, 21

Chestnuts ......65

Chimney Bell .....4
Chinese Arborvitae 8 Chionanthus ….25 Chives ..........

Chokeberry ........31

Christmas Rose ...47

Chrysanthemum ..4

Cimicifuga...$\ldots 4$

Cinnamon Fern ...54

Cladrastris $\ldots \ldots \ldots$

Clematis .....39, 44

Clethra ...........25

Cobaea ...........

Coleus .............

Columbines ......4

Colutea Plant ....

Comptonia ........25

Cone Flower $\ldots . . .4$

Convallaria .......44

Coral Bells .........4

Corchorus ........29

Coreopsis .........

Cornel ...........26

Cornus ..........18, 26

Corylus ........25

Coventry Beils .....4

Cowslip ..........52

Crab Apples ...61

Crataegus ...........18

Creep'g Buttercup 52

Crystal Palace ....5

Cup and Saucer ....43

Cupressus ........8

Currant, Flwg. ...31

Cydonia $\ldots \ldots \ldots \ldots 26$

Cypress
Cypripedium $\ldots \ldots .$.

Dahlias .......56

Daisies $\ldots \ldots 42,44,58$

Daphne .......14, 26

Day Lily ......46, 47

Delphinium ......44

Desmodium ......29

Deutzia .........27

Dewberry …...66

Dianthus $\ldots \ldots \ldots \ldots 45$

Dicksonia ........

Dictamnus .......46

Diervilla

Digitalis

Dodecatheon .....44

Dogwood .....18, 26

Dolichos .........40

Douglas Spruce.....46

Dracunculus ......58

Dusty Miller ......41

Dutchman's Pipe ...39

Echinacea

Echinops

Elder us ......27

Elephant's Ear 55,58

Elm .........23

English Daisy ....43

Erianthus …...46

Epilobium …....46

Erigeron $\ldots \ldots \ldots 46$

Eryngium $\ldots \ldots \ldots .46$

Eulalia ...........46

Euonymus …...

Eupatorium $\ldots \ldots \ldots 46$

Evergreens ….8-15

Exochorda .......27

Fagus

False Chamomile .. 43

False Dragon Head 50

False Indigo ......4

False Sunflower ...

Fan-trained Fruit

Trees Gi.......69

Feather Grass . . . 53
Ferns ........54

Fertilizer …......70

Fescue 'Grass ....46

Festuca .......46

Feverfew $\ldots \ldots 52,58$

Filbert .........25

Fire $\operatorname{Pink} \ldots \ldots \ldots \ldots$

Flame Flower ...54

Flax .........48

Fleabane ......44

Forget-Me-Not ...49

Forsythia .......28

Foxglove …...46

Fraxinus $\ldots \ldots \ldots 19$

Funkia .......46

Gaillardia ......46

Garland Flower ...14

Gas Plant ......46

Genista ..........28

Gentiana ...........4

Geranium $\ldots \ldots 46,58$

Giant Primrose 46, 52

Gillenia $\ldots \ldots \ldots \ldots 46$

Ginkgo

Giadioli $\ldots$

Gleditschia ........19

Globe Flower. 29, 54

Globe Thistle ....46

Goat's Beard ......53

Golden Bell .......2

Golden Feather ...58

Golden Glow ......5.

Golden Marguerite 4

Golden Moss .......52

Golden Rod

Goodyera

Gooseberries $\ldots . .5$

Gossamer Fern ....54

Grapes ........66

Grass Seed ....... 70

Greek Valerian ...52

Ground Nut .....4

46

Hair Grass

Halesia.

Hamameli

Heart's Eas

Heather

Hedera

Helianthemi....

Helianthus

Heliopsis

Heliotrope

Hemerocall

Hepatica

Hercules' club

Hesperis

Heuchera

Hibiscus 


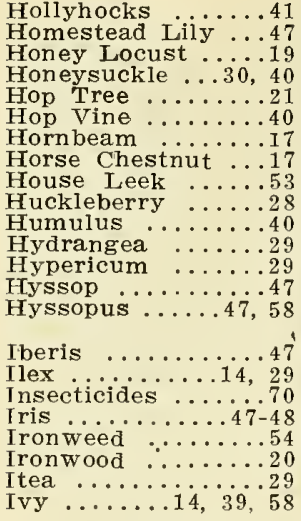

Jacob's Ladder ....52 Japanese Maples ..17 Jerusalem Artichoke

Judas Tree........... Judas Tree Duneberry Juniper ........... 8 Jupiter's Flower ...41

Kadsura Tree ......18 Kalmia ............14 Kentucky Coffee Tree

........

King's spear ......44

Koelreuteria .......

Kudzu Vine .......40

Laburnum ......19

Larch .............

Larix ..............

Larkspur .............

Laurel $\ldots \ldots \ldots \ldots . . .14$

Lavandula .........

Lavender ciotion...58

Lavender Cotton ..5

Leopard's Bane ...46

Lespedeza .......2

Leucothoe ..........14

Ligustrum $\cdots \cdots \cdots 30$

Lilies ........23, 33

Lilium .......... 48

Lily of the Valley. .4

Lime ........2

Linaria $\ldots \ldots \ldots \ldots . .23$

Linum .......... 48

Liriodendron $\ldots \ldots 19$

J obelia . . . . 49, 5

Locust

London Pride .......4

Lonicera 30,40

Loosestrife ….........

Lungwort .........4949

Lupin ...............

iupinus

Lycium

Lysimachia ......49

Madwort

Magnolias ..... $19-20$

Mahonia ........ 14

Maidenhair Fern $\cdots 54$ Maidenhair Tree ..19 Mallow Marvels ...47 Mandrake .............52 Maple ......... 16-1 Marigold ........58 Marsh Mallow ....4 Matrimony Vine ...3 Meadow Beauty ...5 Meadow Rue .....5
Meradow Sweet $, 32,53$

Melissa .....49,58

Men tha .......49, 58

Mertensia .......49

Mezereon ........26

Michaelmas Daisies 42

Milfoil

Mitchella ..........49

Moccasin Flower...54

Mock Orange .....30

Monarda ........449

Moneywort ......49

Monkshood …....4.

Montbretias......557

Morus ..........20

Mountain $\mathrm{A}$ sh $\ldots . .21$

Mountain Fleece...

Mouse Ear ......44

Mulberry .......20

Myosotis .........49

Myrica $\ldots \ldots \ldots . \% 30$

Nasturtiums ....58

Nectarines $\ldots \ldots \ldots 65$

Nepeta $\ldots \ldots \ldots 58$

New Jersey Tea ...25

Nicotiana .........58

Nut Tree $\ldots \ldots \ldots 58$

Nyssa $\ldots \ldots \ldots \ldots 20$

Oak …....... 22

old Woman ........44

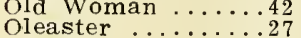

Oleaster ........

Onoclea $\ldots \ldots \ldots \ldots$
Opuntia $\ldots \ldots \ldots$
Orenta

Orchids .........54

Origanum .......449

Orobus ........ 49

Osmunda $\ldots \ldots \ldots .54$

Ostrich Fern $\ldots \ldots .54$
Ostrya $\ldots \ldots \ldots \ldots 20$

Oswego Tea.........49

Ox-Eye .....43, 46

Pachysandra ....49

Paeonies $49-50$

Pampas Grass ....46

Pansy .......... 58

Papaver ........50

Partridge Berry ...49

Pavia ........20

Peach, Flowering ..20

Peaches

Pearl Bush .........27

Pears $\ldots \ldots \ldots \ldots 61-62$

Pentstemon

Peppermint

Periploca

Periwinle

Peppermint ...49, 58

Persica ........20

Peruvian Lily .....4

Petunia $\ldots \ldots \ldots . .58$

Phellodendron .....20

Phlox ......51, 58

Philadelphus ......30

Physostegia ......50

Picea ......... 9

Pine ..........

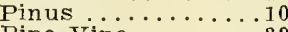

Pipe Vine .......39

Plantain Lily ....446

Planting Directions 2 Planting to Attract Birds

Platanus

Platycodon

Plumbago

Plume Poppy

Podophylium .....

Polomonium ...... 5

Polygonatum ....52

Polygonum ....40, 52

Foplar .......... 20

Poppies $\ldots \ldots \ldots \ldots$

Populus . . . . . . . 20
Potentilla ....... 30

Pot Marjoram ....49

Prickly Pear .....49

Primrose .......4 49

Primula .......5

Privet ........3

Prunus $\ldots . . .21,31$

Ptelea $\ldots \ldots \ldots \ldots \ldots 21$

Pseudotsuga $\ldots \ldots \ldots 54$

Pueraria .........40

Pyrethrum ......... 52

Quercus .......22

Quinces ...........

Ragged Robin ....49

Ranunculus ......52

Raspberries .....67

Rattlesnake-Plàn-

tain ..........54

Ravenna Grass ...446

Red Bud ........ I8

Red Crane's Bill ...46

Retinospora ...........

Rhamnus ..........

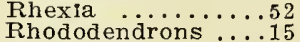

Rhodora ..........31

Rhodotypus .......31

Rhubarb ......6.68

Rhus ..................

Ribbon Grass …...50

Ribes ..............31

Ricinus $\ldots \ldots \ldots \ldots 58$

Robinia ......22, 31

Rock Cress $\ldots \ldots 42,43$

Rock Foil .........52

Rose of Sharon ....28

Roses .....32, $35-38$

Rubus $\ldots \ldots \ldots \ldots 32$

Rudbeckia .... ${ }^{5}{ }^{52}$

Rumex ...........58

Ruta .......52, 58

St. Bruno's Lily ...41

St. John's Wort ...29

Sage ..............58

Salisburia $\ldots \ldots \ldots . .19$

Salix $\ldots \ldots \ldots \ldots .22$

Sambucus .........32

Sanguinaria ..........

Santolina .........52

Saponaria ..........52

Sassafras .........23

Saxifraga $\quad \ldots \ldots \ldots 52$

Scabiosa $\ldots \ldots \ldots .52$

Sea Buckthorn ...29

Sea Holly .........46

Sea Lavender ......53

Sedum ...........52

Sempervivim $\ldots \ldots 53$

Sensitive Fern ....54

Shadbush .......24

Shepherdia ......32

Shooting Star .....46

Siberian Pea Tree..25

Silk Vine .........

Silphium ......... 53

Sisyrinchium ....5

Snakeroot ....44, 46

Snapdragon ......58

Sneezewort .....46

Snowball ..............

Snowberry ..........33

Snowdrop Tree ....28

Solidago Solomon ......

Sorrel

Sorrel Tree .......17

Sour Gum ..........20

Southernwood ....44

Spanish Bayonet ..15

Spearmint $\ldots \ldots 49$, 58

Speedwell .......54

Spice Bush $\ldots \ldots \ldots 24$

Spindle Tree .......27

Spirea ........32, 53

Spruce $\ldots \ldots \ldots \ldots .99$
Spurge $\ldots \ldots \ldots \ldots 46$

Stachys $\ldots \ldots \ldots \ldots \ldots 53$

Star Grass ......53

Statice $\ldots \ldots \ldots \ldots 53$

Stephanandra ....33

Stipa .........53

Stocks, $\not \ldots \ldots \ldots \ldots 58$

Stokes Aster .....53

Stokesia ........53

Strawberry Plants.6. 68

Strawberry Tree ..27

Sumach ...........31

Sunflower ......4 4

Sun Rose ........46 46

Sweet Fern ......25

Sweet Gum ......19

Sweet Shrub .....24

Sweet Woodruff ...44

Symphoricarpos ...33

Syringa ...23, 30, 33

Tamarisk ......34

Tamarix ............

Tarragon $\ldots \ldots .42,58$

Taxodium ........23

Taxus .......... 11

Thalictrum ....... 53

"The Pearl" .......41

Thermopsis ......53

Thorn $\ldots \ldots \ldots 18$

Thuya $\ldots \ldots \ldots \ldots \ldots 12$

Thyme ......53, 58

Thymus $\ldots \ldots \ldots 53,58$

Tickseed ........44

Tigrida ......... 57

Tilia $\ldots \ldots \ldots \ldots .23$

Toad Flax ....... 48

Tobacco Plant ....58

Trailing Myrtle ...54

Tree of Heaven ....17

Trillium ....... 54

Tritoma ...... 54

Trollius .......5 54

Trumpet Vine ....40

Tsuga ...........12

Tuberose $\ldots \ldots \ldots \ldots 5$

Tulip Tree ....... 19

Tunica ........ 54

Tupelo Turtle Head $\ldots \ldots .44_{4}$

Ulmus ........23

Umbrella Pine ...11

Vaccinium ......34

Valerian .........44

Valeriana ...........

Varnish Tree ...... 19

Vernonia .......54

Veronica .......54

Viburnum ............

Vinca .............54

Viola $\ldots \ldots \ldots \ldots \ldots .54$

Violet $\ldots \ldots \ldots \ldots 34$
Vines . . .

Virgin's Bower ...39

Vitis .........40

Wallflower .......58 


\section{Approximate Express and Freight Rates on Nursery Stock to Principal Shipping Points}

\begin{tabular}{|c|c|c|c|c|}
\hline \multirow{2}{*}{\multicolumn{2}{|c|}{ From Bedford, via Lowell, Massachusetts, to }} & \multicolumn{3}{|c|}{ Rates per 100 pounds } \\
\hline & & \multirow{2}{*}{$\frac{\text { Express }}{\$ 1.75}$} & \multirow{2}{*}{$\begin{array}{c}\begin{array}{c}\text { Freight } \\
\text { Boxed }\end{array} \\
\$ 0.42\end{array}$} & \multirow{2}{*}{$\begin{array}{c}\begin{array}{c}\text { Freight } \\
\text { Baled }\end{array} \\
\$ \$ 0.53\end{array}$} \\
\hline $\begin{array}{l}\text { Columbia, District of . . . } \\
\text { Connecticut } \ldots \ldots \ldots \ldots\end{array}$ & 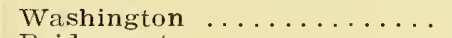 & & & \\
\hline Connecticut $\ldots \ldots \ldots \ldots$ & Bridgeport $\ldots \ldots \ldots \ldots \ldots \ldots$ & 1.10 & .28 & .34 \\
\hline & 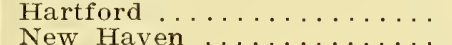 & 1.10 & .26 & .32 \\
\hline & $\begin{array}{l}\text { New Haven } \ldots \ldots \ldots \ldots \ldots \ldots \\
\text { New London } \ldots \ldots \ldots \ldots\end{array}$ & $\begin{array}{l}1.10 \\
1.00\end{array}$ & $\begin{array}{l}.26 \\
.26\end{array}$ & .32 \\
\hline Delaware & 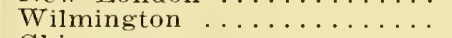 & 1.50 & $\begin{array}{l}.26 \\
.36\end{array}$ & $\begin{array}{l}.32 \\
.46\end{array}$ \\
\hline Illinois $\ldots \ldots \ldots \ldots \ldots$ & $\ldots \ldots \ldots \ldots \ldots$ & 1.90 & .63 & $\begin{array}{r}.40 \\
.83\end{array}$ \\
\hline Indiana $\ldots \ldots \ldots \ldots$ & Indianapolis $\ldots \ldots \ldots \ldots \ldots$ & 1.75 & .59 & .78 \\
\hline Iowa ... & Des Moines ............. & 3.00 & 1.00 & 1.39 \\
\hline Kentucky & Louisville $\ldots . \ldots \ldots \ldots \ldots$ & 1.90 & .63 & .83 \\
\hline \multirow[t]{3}{*}{ Maine .. } & Augusta $\ldots \ldots \ldots \ldots \ldots \ldots$ & .80 & .33 & .33 \\
\hline & Bangor $\ldots \ldots \ldots \ldots \ldots \ldots$ & 1.00 & .33 & .33 \\
\hline & Lewiston $\ldots \ldots \ldots \ldots \ldots \ldots$ & .80 & .29 & .38 \\
\hline Maryland $\ldots \ldots \ldots \ldots$ & Portland ............. & .50 & .25 & .25 \\
\hline \multirow[t]{20}{*}{ Massachusetts $\ldots \ldots \ldots \ldots$} & $\begin{array}{l}\text { Baltimore } \ldots \ldots \ldots \ldots \ldots \ldots \\
\text { Boston } \ldots \ldots \ldots\end{array}$ & $\begin{array}{r}1.40 \\
40\end{array}$ & .40 & .50 \\
\hline & $\begin{array}{l}\text { Brockton } \\
\text { Brock } \ldots \ldots \ldots \ldots \ldots \ldots\end{array}$ & $\begin{array}{l}.40 \\
.65\end{array}$ & $\begin{array}{l}.08 \\
.18\end{array}$ & .08 \\
\hline & Brookline ............ & .40 & & .21 \\
\hline & Cambridge $\ldots \ldots \ldots \ldots \ldots$ & .40 & & \\
\hline & Dedham $\ldots \ldots \ldots \ldots \ldots \ldots$ & .65 & .15 & .18 \\
\hline & Fall River $\ldots \ldots \ldots \ldots \ldots \ldots$ & .65 & .23 & .27 \\
\hline & $\begin{array}{l}\text { Fitchburg } \ldots \ldots \ldots \ldots \ldots \ldots \\
\text { Lawrence } \ldots \ldots \ldots \ldots\end{array}$ & .40 & .17 & .17 \\
\hline & $\begin{array}{l}\text { Lawrence } \ldots \ldots \ldots \ldots \ldots \ldots \ldots \\
\text { Lowell } \ldots \ldots \ldots \ldots \ldots \ldots \ldots\end{array}$ & .40 & .12 & .12 \\
\hline & Lynn $\ldots \ldots \ldots \ldots \ldots \ldots \ldots$ & .40 & .13 & $\begin{array}{l}.09 \\
.13\end{array}$ \\
\hline & New Bedford ........... & .75 & .23 & $\begin{array}{l}.13 \\
.28\end{array}$ \\
\hline & 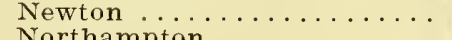 & .40 & .14 & .16 \\
\hline & Northampton $\ldots \ldots \ldots \ldots \ldots$ & .75 & .24 & .24 \\
\hline & Pittsfield $\ldots \ldots \ldots \ldots \ldots \ldots$ & .80 & .20 & .20 \\
\hline & $\begin{array}{l}\text { Plymouth } \ldots \ldots \ldots \ldots \ldots \ldots \ldots \ldots \ldots \ldots \ldots \\
\text { Quincy } \ldots \ldots \ldots \ldots \ldots \ldots\end{array}$ & .85 & .19 & .24 \\
\hline & Roxbury $\ldots \ldots \ldots \ldots \ldots \ldots$ & $\begin{array}{l}.00 \\
.40\end{array}$ & .16 & .18 \\
\hline & Salem $\ldots \ldots \ldots \ldots \ldots \ldots$ &. \pm 0 & .13 & \\
\hline & Somerville $\ldots \ldots \ldots \ldots \ldots$ & .40 & & .13 \\
\hline & South Framingham $\ldots \ldots \ldots$ & .40 & .16 & .18 \\
\hline & $\begin{array}{l}\text { Springfield } \ldots \ldots \ldots \ldots \ldots \ldots \\
\text { Woods Hole }\end{array}$ & .75 & .24 & .24 \\
\hline & 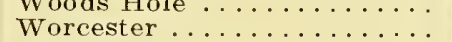 & $\begin{array}{r}1.00 \\
.50\end{array}$ & .25 & .28 \\
\hline Michigan & Detroit $\ldots \ldots \ldots \ldots \ldots$ & 1.50 & .51 & .15 \\
\hline Minnesota & Minneapolis ............. & 3.00 & .92 & 1.23 \\
\hline Missouri $\ldots . .$. & St. Louis . . . . . . . . . . . & 2.25 & .73 & .96 \\
\hline \multirow{4}{*}{ New Hampshire. } & 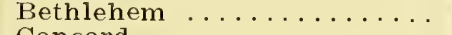 & 1.00 & .39 & .39 \\
\hline & Concord $\ldots \ldots \ldots \ldots \ldots \ldots$ & .50 & .18 & .18 \\
\hline & Manchester ............ & .40 & .15 & .15 \\
\hline & Nashua $\ldots \ldots \ldots \ldots \ldots \ldots$ & .40 & .11 & .11 \\
\hline \multirow{2}{*}{ New Jersey $\ldots \ldots \ldots \ldots$. } & Portsmouth $\ldots \ldots \ldots \ldots \ldots$ & .50 & .19 & .19 \\
\hline & Newark ............... & 1.40 & .34 & .43 \\
\hline \multirow{4}{*}{ New York ............ } & Trenton & 1.40 & .34 & .43 \\
\hline & $\begin{array}{l}\text { Albany } \\
\text { Buffalo }\end{array}$ & $\begin{array}{r}.80 \\
1.20\end{array}$ & $\begin{array}{l}31 \\
40\end{array}$ & .38 \\
\hline & New York $\ldots \ldots \ldots \ldots \ldots \ldots \ldots$ & $\begin{array}{r}1.20 \\
.80\end{array}$ & $\begin{array}{l}.40 \\
.33\end{array}$ & .52 \\
\hline & Syracuse $\ldots \ldots \ldots \ldots \ldots \ldots$ & 1.20 & $\begin{array}{l}.33 \\
.36\end{array}$ & .42 \\
\hline \multirow{3}{*}{ Ohio $\ldots \ldots \ldots \ldots \ldots$} & Cincinnati $\ldots \ldots \ldots \ldots$ & 1.50 & .56 & $\begin{array}{l}.46 \\
.73\end{array}$ \\
\hline & Cleveland $\ldots \ldots \ldots \ldots \ldots$ & 1.40 & .47 & .61 \\
\hline & 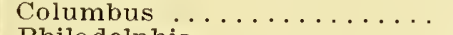 & 1.50 & .51 & .67 \\
\hline \multirow{3}{*}{ Pennsylvania } & Philadelphia $\ldots \ldots \ldots \ldots \ldots$ & 1.40 & .29 & .38 \\
\hline & Pittsburgh $\ldots \ldots$ & 1.50 & .45 & .58 \\
\hline & Scranton $\ldots \ldots \ldots \ldots \ldots \ldots$ & 1.40 & .36 & .46 \\
\hline $\begin{array}{l}\text { Phode Island } \ldots \ldots \ldots \ldots \\
\text { Vermont } \ldots \ldots \ldots \ldots \ldots\end{array}$ & Newport $\ldots \ldots \ldots \ldots \ldots \ldots$ & .80 & .24 & .28 \\
\hline \multirow{3}{*}{ Vermont $\ldots \ldots \ldots \ldots \ldots$} & Providence & .65 & 20 & .25 \\
\hline & $\begin{array}{l}\text { Bennington } \\
\text { Burlington }\end{array}$ & $\begin{array}{l}1.00 \\
1.20\end{array}$ & $\begin{array}{l}.55 \\
.46\end{array}$ & $\begin{array}{l}.55 \\
.46\end{array}$ \\
\hline & Montpelier ...... & 1.00 & .46 & $\begin{array}{l}.40 \\
.46\end{array}$ \\
\hline Wisconsin & Milwaukee $\ldots \ldots \ldots \ldots \ldots \ldots$ & 2.10 & .63 & .83 \\
\hline
\end{tabular}

When stock is shipped by freight via Boston, there will be a charge for transferring across the city, in addition to above freight rate, about as follows: 100 tbs., 25 cts.; 300 lbs., 35 cts.; 500 lbs., 50 cts.; 1,000 lbs., $\$ 1.00$. 


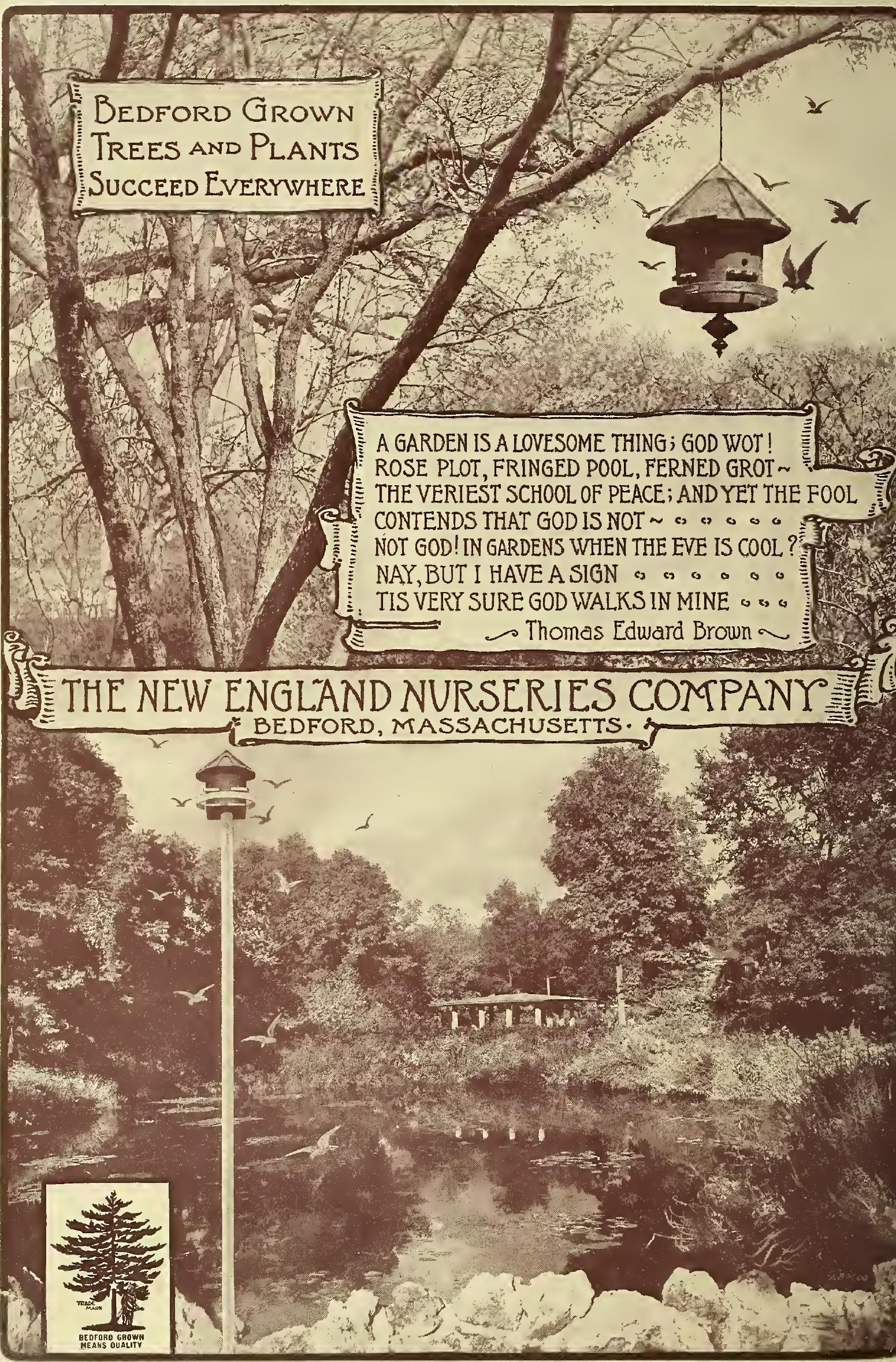

